\title{
arts
}

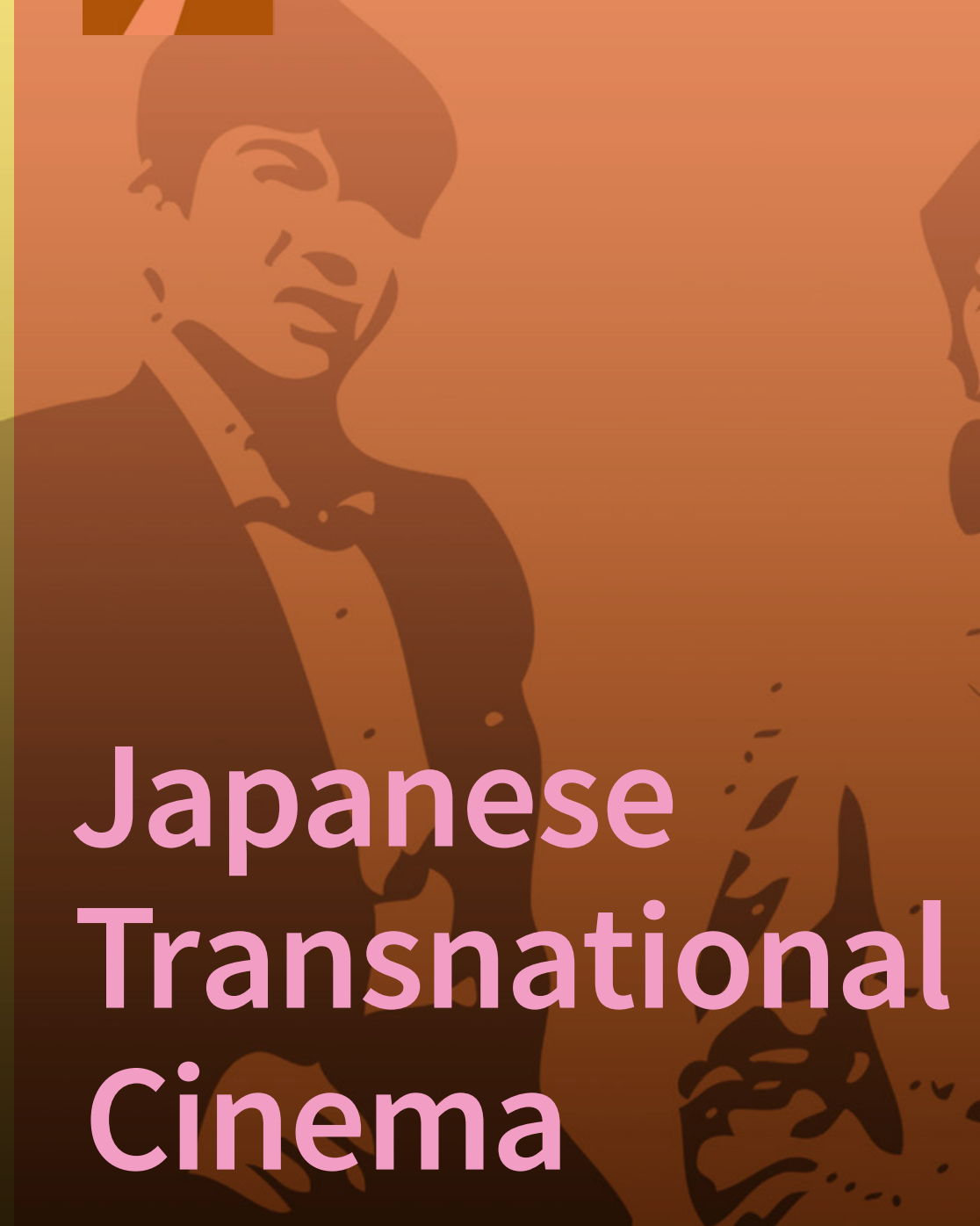

Edited by

Marcos P. Centeno-Martín and Norimasa Morita

Printed Edition of the Special Issue Published in Arts 


\section{Japanese Transnational Cinema}





\section{Japanese Transnational Cinema}

Special Issue Editors

Marcos P. Centeno-Martín

Norimasa Morita

MDPI • Basel • Beijing • Wuhan • Barcelona $\bullet$ Belgrade $\bullet$ Manchester $\bullet$ Tokyo $\bullet$ Cluj $\bullet$ Tianjin

\section{MDPI}


Special Issue Editors

Marcos P. Centeno-Martín

Norimasa Morita

University of London

Waseda University

UK

Japan

\section{Editorial Office}

MDPI

St. Alban-Anlage 66

4052 Basel, Switzerland

This is a reprint of articles from the Special Issue published online in the open access journal Arts (ISSN 2076-0752) (available at: https:/ / www.mdpi.com/journal/arts/special_issues/Japanese_ Transnational_Cinema).

For citation purposes, cite each article independently as indicated on the article page online and as indicated below:

LastName, A.A.; LastName, B.B.; LastName, C.C. Article Title. Journal Name Year, Article Number, Page Range.

ISBN 978-3-03936-156-4 (Hbk)

ISBN 978-3-03936-157-1 (PDF)

Cover image courtesy of Nikkatsu and Almudena García Navarro.

(C) 2020 by the authors. Articles in this book are Open Access and distributed under the Creative Commons Attribution (CC BY) license, which allows users to download, copy and build upon published articles, as long as the author and publisher are properly credited, which ensures maximum dissemination and a wider impact of our publications.

The book as a whole is distributed by MDPI under the terms and conditions of the Creative Commons license CC BY-NC-ND. 
Acknowledgements: this special issue is an outcome of a wide project entitled "Japanese Transnational Cinema" led between Birkbeck, University of London and Waseda University, which counted on the collaboration of colleagues from European, Japanese and American universities as well as the generous support from DAIWA Anglo-Japanese (Ref: 197/13307) and Great Britain Sasakawa Foundation (Ref. No. 5558) and MEXT-Top Global University Project to whose generosity the editors are deeply indebted.
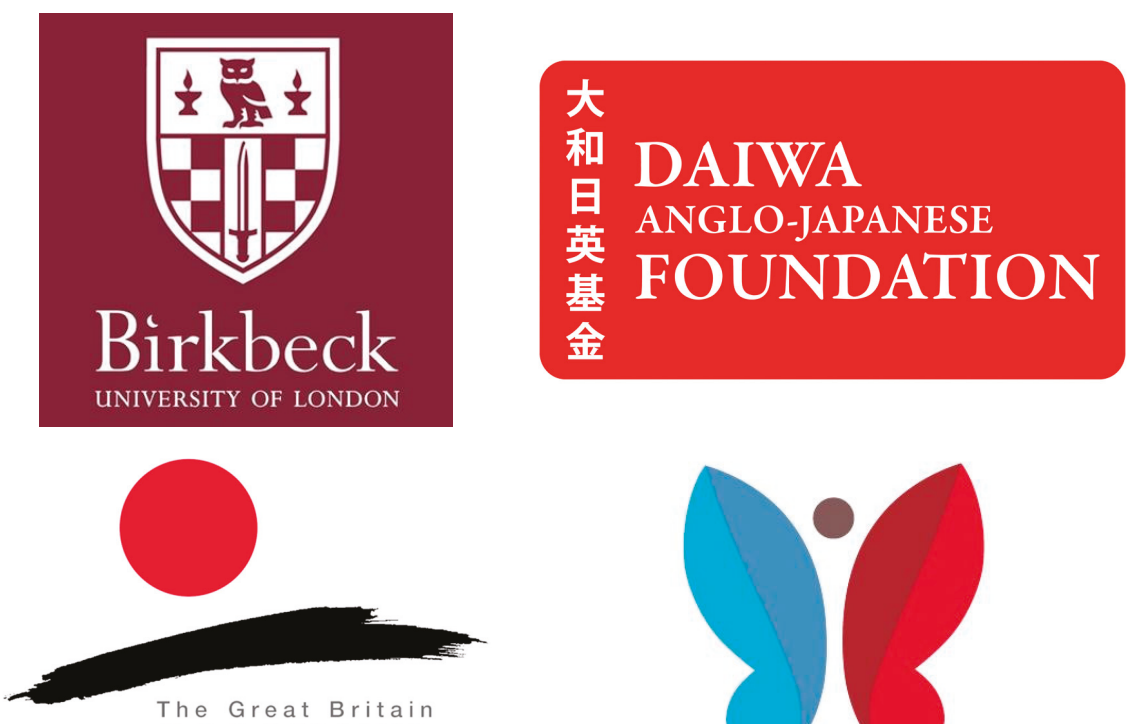

SASAKAWA FOUNDATION クレイトブリテン・ササカワ財団
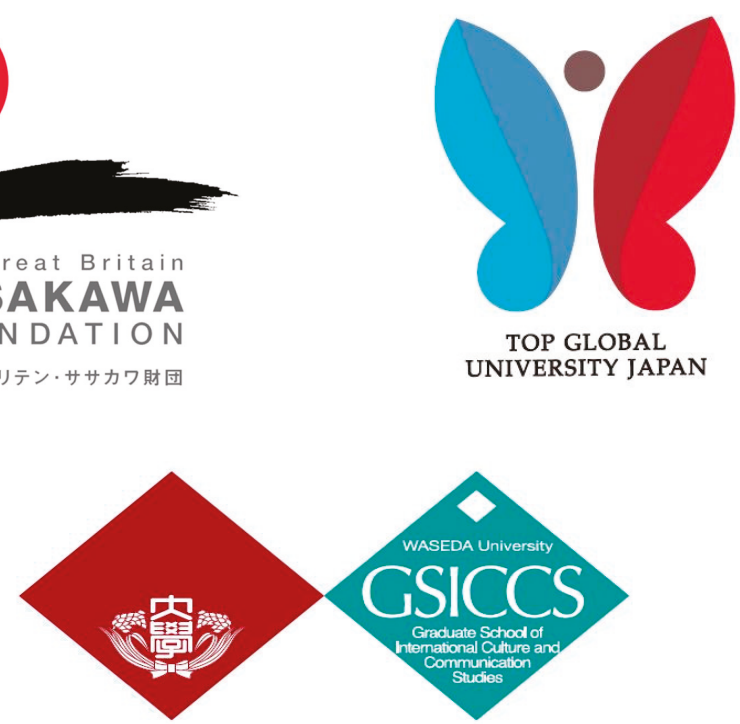



\section{Contents}

About the Special Issue Editors $\ldots \ldots \ldots \ldots \ldots \ldots \ldots \ldots$

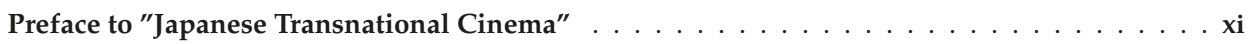

Marcos P. Centeno-Martín and Norimasa Morita

Japan and the "Transnational Cinema"

Reprinted from: Arts 2020, 9, 50, doi:10.3390/arts9020050 . . . . . . . . . . . . . . . . 1

\section{Marcos P. Centeno-Martín}

Introduction. The Misleading Discovery of Japanese National Cinema

Reprinted from: Arts 2018, 7, 87, doi:10.3390/arts7040087 . . . . . . . . . . . . . . . . 7

\section{Dolores P. Martinez}

From 'Scottish' Play to Japanese Film: Kurosawa's Throne of Blood

Reprinted from: Arts 2018, 7, 50, doi:10.3390/arts7030050 . . . . . . . . . . . . . . . . 21

\section{Simon Frisch}

The Aesthetics of Flow and Cut in the Way of Film: Towards Transnational Transfers of East Asian Concepts to Western Film Theory

Reprinted from: Arts 2019,8,119, doi:10.3390/arts8030119 . . . . . . . . . . . . . . . . . 33

\section{Ferran de Vargas}

Japan's New Left and New Wave. An Ideology's Perspective as an Alternative to That of National Cinema

Reprinted from: Arts 2019, 8, 1, doi:10.3390/arts8010001

\section{Griseldis Kirsch}

Gendering the Japanese Empire: Ri Kōran as 'Transnational' Star?

Reprinted from: Arts 2019,8,153, doi:10.3390/arts8040153 . . . . . . . . . . . . . . . . 59

\section{Kentaro Kawashima}

Metamorphosis as Origin-Koji Yamamura's Short Animation Franz Kafka's A Country Doctor Reprinted from: Arts 2019,8,54, doi:10.3390/arts8020054 . . . . . . . . . . . . . . . . . . 67

\section{Rosanna Mestre Pérez}

Japan in Spain. Japanese Culture through Spanish Eyes in the Film Gisaku

Reprinted from: Arts 2018, 7,93, doi:10.3390/arts7040093 . . . . . . . . . . . . . . . 75

\section{Miguel Muñoz-Garnica}

Intertextuality and Mise en Abyme in Nobuhiro Suwa's H Story and A Perfect Couple. Between

European Modernity and Japan

Reprinted from: Arts 2018, 7,57, doi:10.3390/arts7040057 . . . . . . . . . . . . . . . . . 89

\section{Erin Schoneveld}

Naomi Kawase's "Cinema of Place"

Reprinted from: Arts 2019,8,43, doi:10.3390/arts8020043 . . . . . . . . . . . . . . . . . 103 



\section{About the Special Issue Editors}

Marcos P. Centeno-Martín is Lecturer in Japanese Studies and coordinator of the Japanese Programme at Birkbeck, University of London. Before that, he worked for the department of Japan and Korea at SOAS, where he taught several courses on Japanese Cinema and convened the MA Global Cinemas and the Transcultural. Centeno Martín has also served as Research Associate at Waseda University and Research Fellow at the Universitat de València. His research interests revolve around Japanese documentary film, Hani Susumu, film theory, transnationality, postwar avant-garde and the representation of minorities.

Norimasa Morita is Professor in film and literary study and served as Dean of the School of International Liberal Studies and Vice-President for international affairs at Waseda University. He obtained his Ph.D. from University of Kent, Canterbury, in 1991 and has been teaching and researching mainly film and literary theory at Waseda University. His research interests include realism in film and literature, postmodernism, and adaptation practice and theory, and the topics of his recent publications include non-English adaptations of Shakespeare's plays, fictionalisation of historical figures and events, and Japanese writers and filmmakers in Great Britain. 



\section{Preface to "Japanese Transnational Cinema"}

The aim of this Special Issue lies in expanding contemporary discussions on Japanese Cinema and its transnational aspects by applying new critical methodologies and stances and in revealing the contradictions inherent in the way the old paradigm of 'National Cinema' has traditionally been articulated. In order to do so, this publication highlights the limitations of assessing Japanese film as a cinematic phenomenon confined to its national borders. Throughout this issue, the concept of transnationality is not confined to a single definition and is instead used as an analytical framework which allows authors to surpass narrow perspectives that neglect the complex nature of Japanese film in terms of its esthetics, narratives, and theoretical approaches as well as production, consumption, and distribution systems.

This volume casts light on the extraordinary international flows of images, stories, iconographies, and theories between Japan and other countries, and assesses the dialectic relationship between two apparently contradictory aspects: external influences and Japanese uniqueness, revealing how 'uniquely Japanese' films may ironically contain foreign codes of representation. Thus, the articles presented here bring a more comprehensive understanding of how global cultural flows have shaped local creativity. Some authors adopt additional transnational perspectives through which they analyse how Japan is represented as 'other' from outside and how the rest of the world is represented by Japan, or propose a renewal of film theories on Japanese cinema that have traditionally been dominated by Western writings. Overall, manuscripts included in this publication help the reader to understand different ways in which Japan expands beyond Japanese Cinema and Japanese Cinema expands beyond Japan.

Marcos P. Centeno-Martín, Norimasa Morita Special Issue Editors 



\title{
Editorial
}

\section{Japan and the "Transnational Cinema"}

\author{
Marcos P. Centeno-Martín ${ }^{1, *}$ and Norimasa Morita ${ }^{2, *}$ \\ 1 Department of Cultures and Languages, School of Arts, Birkbeck, University of London, \\ London WC1E 7HX, UK \\ 2 Graduate School of International Culture and Communication, Waseda University, Tokyo 169-8050, Japan \\ * Correspondence: m.centeno@bbk.ac.uk (M.P.C.M.); norm@waseda.jp (N.M.)
}

Received: 27 March 2020; Accepted: 12 April 2020; Published: 17 April 2020

Since the Western "discovery" of Japanese cinema in the 1950s, there has been a tendency among both Film Studies and Japanese Studies scholars to draw on essentialist visions of Japanese Cinema, understating its uniqueness as a consequence of its isolation from the rest of the world. In other words, Japanese Cinema has often been regarded as an inseparable part of Japan's unique culture, and film scholars have been making tremendous efforts to prove that Japanese Cinema developed independently of Western forms of cinematic representation. One of the earliest examples of this "Oriental turn" can be found in Burch's influential text To the Distant Observer (1979), which highlighted how the evolution of Japanese film was thickly informed by its own cultural heritage and developed in correlation with its artistic, aesthetic, and philosophical traditions. This critical tendency of trying to find in Japanese cinema a way of filmmaking alternative to Hollywood's was consistent with what filmmakers of New Waves and Third Cinemas in the 1960s and 70s aimed at and practiced.

Any film critics and historians emphasising "national" essence in Japanese films are prone to conceptual mistakes: such reductive views lead to the underestimation of filmmakers' full artistic creativity. Such an arbitrary stance results in neglecting the complex interactions of local, transnational and global cinematic components. Cinema has been international since its inception, and in this sense Japanese cinema, one of the oldest in the world, is not an exception. The paradigm of "National Cinema" started to be increasingly called into question from the late 1980s (Higson 1989; Elsaesser 1989), and soon new methodological approaches to Japanese cinema, too, started to be proposed by various scholars (Gerow 1993; Andrew and Raine 1993; Iwamoto 1993), which helped bring understanding of the contradictions and fault lines of "distant observers" and cast light on the dialectical relationships in filming practice, and film theory and criticism between Japan and the rest of the world.

During the last decade, the concept of transnationality in cinema has pervaded Film Studies, and in 2010 a new journal, Transnational Cinemas, was launched to host the ongoing discussions in this field. Ezra and Rowden (2006) pioneered the theorization of transnational film, which has been followed by studies engaged in nailing down the meanings of transnational cinema (Hjort 2010; Higbee and Lim 2010; Ezra and Rowden 2006; Berry 2010; Higbee and Lim 2010). Other authors have embarked on projects dismantling national boundaries from various different angles and come up with a variety of terms for "transnational cinema" such as "global cinema" (Galt and Schoonover 2010), "impure cinema" (Nagib 2019), "multicultural [cinema]" (Kō 2009), the "transcultural [cinema]" (Lau 2002), "diasporic cinema" (Petty 2008; Berghahn and Sternberg 2010), "accented cinema" (Naficy 2001) and "translocal imagination" (Miyao 2019). Concurrently with these theoretical discussions, studies applying "transnationality" to Japanese film have proliferated in recent years (Miyao 2007, 2017; Baskett 2008; Tezuka 2011; Brizio-Skov 2016; Dorman 2016; Dew 2016; Centeno Martín 2016, 2017a, 2017b, 2019; Centeno Martín and Morita 2020). This Arts Special Issue expands contemporary discussions of transnational Japanese cinema by proposing new theoretical frameworks, analytical methodologies and critical approaches. Our aim is to challenge the old "national" paradigm by highlighting the limitations of studying Japanese film as a cinematic phenomenon confined to its national borders. Is Japanese cinema National Cinema? To what extent is Japanese cinema Japanese? 
This publication emerges as part of a collaborative project entitled "Japanese Transnational Cinema" led by Birkbeck College, University of London and Waseda University in Tokyo. Partial results were presented in two symposia: one held at Birkbeck in May 2019 and one at Waseda in July 2019. These international meetings were possible thanks to generous support from institutions such as Daiwa Anglo-Japanese Foundation; Great Britain Sasakawa Foundation; MEXT-Top Global University Project Fund; as well as to the collaboration of scholars from other universities such as SOAS, Kyoto University, Nagoya University, Ochanomizu University and Sugiyama Jogakuen University.

As has been noted, there is no single definition for transnational cinema (Shaw 2013; Centeno Martín and Morita 2020), and we do not claim any single methodology as a variety of approaches to the transnational are beneficial in assessing all aspects of this increasingly complex phenomenon. It will be more productive to understand the "transnational" as an area of theoretical inquiry, that is, transnational film theory (Fisher and Smith 2020), than to seek the definitive notion of it. The papers represented here propose innovative approaches to Japanese cinema, surpassing narrow "national" perspectives that neglect the extraordinary transnationality and even global nature of Japanese film in terms of its aesthetics, narratives and theoretical approaches, as well as its production, consumption and distribution systems.

We should not forget that there have been and are, even now, very active international flows in Japan of images, stories, iconographies and theories. As many papers in this volume note, even films considered as milestones of Japanese National Cinema were clearly exposed to foreign influences, such as those of Akira Kurosawa (Martinez 2018), Kenji Mizoguchi and Yasujirō Ozu (Centeno Martín 2018), Yoshishige Yoshida (De Vargas 2019) or Naomi Kawase (Schoneveld 2019). Most of the articles included in this Issue question whether external influences and Japanese film uniqueness are compatible or not, or to what extent Japanese specificity is compromised by foreign codes of representation.

Cross-cultural representation is also part of cinema's transnationality and issues, raising the following questions: What misrecognition and misrepresentation surface when Japan is represented as 'other' from outside (Mestre Pérez 2018) or when the rest of the world is represented by Japan (Kirsch 2019)?; How has the global cultural flow shaped Japanese creativity? (Kawashima 2019; Muñoz-Garnica 2018; Martinez 2018; Centeno Martín 2018). In addition, the film industry has developed complex structures, and the way it operates cannot be completely understood without taking into account its increasing transnational characteristics in production, distribution and consumption (Mestre Pérez 2018; Schoneveld 2019). Questioned, in that sense, is the extent to which films can still be regarded as products of a national domestic market when they are distributed and consumed in the transnational or even global market (Centeno Martín 2018; Martinez 2018). Additionally, Frisch (2019) points out the possibility that Japanese aesthetic and cultural traditions might provide useful tools to renew film theories that have traditionally been dominated by the Western canon of writings and create theoretical frameworks from a transnational perspective. The papers in this Issue present innovative analytical approaches that could unravel cultural complexities of films in a transnational context and propose to assess Japanese and transnational cinematic phenomena from several different perspectives.

Centeno Martín (2018) provides theoretical background to the notion of "national cinema" and discusses the contradictions that are caused when this paradigm is applied to the Japanese case. His article illustrates that what makes Japanese films Japanese are imaginarily created by the Western gaze, which is often blind to transnational influences on Japanese filmmakers. Centeno Martín shows how the idea of "Japanese National Cinema" was originally articulated from outside and presents evidence to prove the weight of Hollywood in Japanese domestic films. Kawashima (2019) explores how metamorphosis becomes a transmedia and transcultural trope and is employed by Koji Yamamura for his Franz Kafka's A Country Doctor based on the Kafka's short story. This article calls into question the national paradigm as, while metamorphosis is a frequently used motif in Japanese animated films, Yamamura's A Country Doctor remains outside the Japanese film culture and instead relies on European aesthetic and philosophical traditions. Kawashima describes Yamamura's animation as an example of transnational cinema, which both adapts and renews foreign cultural elements at the same time. 
De Vargas (2019) questions the validity of the national cinema model by claiming that films should be assessed not in relation to national identities but rather political affiliations. Rather than studying the national culture in a film, his article proposes to analyse certain national ideologies that the film is aligned with. De Vargas uses Kijū Yoshida's Eros + Massacre (1969) to illustrate how the Japanese New Wave can be understood as a result of the filmmakers' alliances with the New Left movement from the late 1950s.

Mestre Pérez (2018) explores a cinematic phenomenon that moves across national boundaries through Gisaku (2005), the Spanish animation film about the Japanese European mission in the 17th century. This film projects a positive image of Spain and reverts predemocratic and premodern images of this country. This case study becomes a unique transnational attempt because it demonstrates the film is designed to meet national interests, while ironically it is made by transnational working teams and targeted at the Japanese audience. Mestre Pérez also defines film as a transcultural production, which seeks channels of interaction between Japan and Spain in order to enhance cultural transferability. Her study then presents a Spanish "national" image that is consumed internationally and may be continuously adapted and renewed. Frisch (2019) challenges Western paradigms used in film theory by introducing concepts rooted in the East Asian aesthetic and cultural tradition. This article draws on Ryōsuke Ōhashi's theoretical work to show how the notion of kire in Japanese traditional art and theatre becomes a useful epistemological tool in analysing bodily movements of film actors and the transitory and ephemeral nature of cinematic images. Frisch proposes a sort of transcultural approach for film theory, and illustrates how concepts that originated in Japanese cultural tradition, such as cut-continuity (kire-tsuzuki), shift (zure) or incompleteness, can be applied not only to Japanese arts (such as ikebana or theatre) but also to both Japanese and international films.

Since his discovery in the West in the 1950s, nobody had been regarded as a "national" filmmaker as much as Kurosawa Akira, and the focus of the study on his films was mainly on his "Japaneseness." Recent scholarship, however, has shifted towards the transnationality of his films, and Martinez's (2018) paper is one of the invaluable contributions to the reappraisal of Kurosawa's closer association with Western cultural traditions and values. Her insight into Kurosawa's adaptation of Macbeth makes it unquestionable that the story of Washizu and Asaji's sense of guilt in The Throne of Blood, retold as if it were a Buddhist morality play, also has a strong affinity with Christian notions of guilt.

Ri Kōran (Yoshiko Yamaguchi, aka. Li Xianglan) was a rare "transnational" star in the prewar and wartime periods, but no audience had known that she was an ethnic Japanese playing roles of nothing but Chinese characters till her true ethnicity was revealed after the end of WWII. Kirsch (2019) investigates how this ethnic ambiguity hides some ideological complexity by closely examining two cinema texts, Suzhou Night and Sayon's Bells, both of which star Yamaguchi. Her article discusses the implications of featuring this figure in war-time films: The Japanese Empire was traditionally envisaged as male, while its colonies such as China and Korea were envisaged as female; Li Xianglan on screen was a colonized subject, while Yamaguchi Yoshiko was in reality a colonizing one.

Atsuhiro Suwa is an undeniable Europhile, and has made films as if they were homages to European film and culture, particularly French ones. Muñoz-Garnica (2018) selects two of Suwa's most European films-H Story and A Perfect Couple - and closely traces the ways in which the first is embedding the story and narrative situation of Hiroshima mon amour and the second those of Rossellini's Journey into Italy as if they were mise en abyme. That $H$ Story is a virtual remake of Hiroshima mon amour is clearly noticeable by everybody who has seen the film, but Japanese film critics and audiences largely miss the mise en abyme structure of A Perfect Couple.

One of the most successful Japanese film directors in international film festivals, and whose films are considered to have great appeal for international audiences, is Naomi Kawase, but Schoneveld (2019) demonstrates that her major works such as Suzaku, Shara and Mogari are inextricably tied to a specific Japanese locality, particularly Nara where she comes from, and her personal identity as Japan's female film author. According to Schoneveld, these films are her "cinema of place," which are also a spatial metaphor for her position as a female film director in Japan. 
In general, all these articles illustrate the need to reformulate the old paradigm of "national cinema", as films in general and Japanese Cinema in particular often expand beyond national borders. This approach should not undermine the weight of Japanese film tradition but, on the contrary, should help us to contextualize it properly within the global culture of images.

Conflicts of Interest: The authors declare no conflict of interest.

\section{References}

Andrew, Dudley, and Michael J. Raine. 1993. Japanese Image Culture. Iris 16: 3-9.

Baskett, Michael. 2008. The Attractive Empire: Transnational Film Culture in Imperial Japan. Honolulu: University of Hawai'i Press.

Berghahn, Daniela, and Claudia Sternberg. 2010. European Cinema in Motion: Migrant and Diasporic Film in Contemporary Europe. Basingstoke: Palgrave Macmillan.

Berry, Chris. 2010. What is Transnational Cinema? Thinking from the Chinese Situation. Transnational Cinemas 1: 2. [CrossRef]

Brizio-Skov, Flavia. 2016. Examples of National and Transnational Cinema: Akira Kurosawa's Yojimbo and Sergio Leone's A Fistful of Dollars. Cultural and Religious Studies 4: 141-60. [CrossRef]

Centeno Martín, Marcos P. 2016. Transcultural Corporeity in Taiyōzoku Youth Cinema. Some Notes on the Contradictions of Japaneseness in the Economic Miracle. In Körperinszenierungen im japanischen Film/Presentation of Bodies in Japanese Films. Edited by Andreas Becker and Kayo Adachi-Rabe. Frankfurt: Büchner-Verlag, pp. 143-60.

Centeno Martín, Marcos P. 2017a. Del Viaje del Turista Al Viaje del Héroe. Mímesis Cinematográfica del Discurso Turístico Japonés Sobre España. El Caso de Andarushia (2011). MIRAI Estudios Japoneses 1: 89-107. [CrossRef]

Centeno Martín, Marcos P. 2017b. Centeno Martín, Marcos P. 2017b. Transnational Circulation of Images of the Pacific War (1941-1945): The Japanese Empire Seen through Spanish Newsreels. Irish Journal of Asian Studies (IJAS) 3: 1-13.

Centeno Martín, Marcos P. 2018. Centeno Martín, Marcos P. 2018. Introduction. The Misleading Discovery of Japanese National Cinema. Arts 7: 87. [CrossRef]

Centeno Martín, Marcos P. 2019. Challenging Eurocentric Surveys. The Transnational Topic in Film Studies. JCMS Teaching Dossier 5 (Revisiting the Film History Survey): 1-5.

Centeno Martín, Marcos P., and Norimasa Morita. 2020. Introduction: Japanese film beyond its national borders. In Japan Beyond its Borders: Transnational Approaches to Film and Media. Edited by Marcos P. Centeno-Martín and Morita Norimasa. Tokyo: Seibunsha, pp. 1-17.

De Vargas, Ferran. 2019. Japan's New Left and New Wave. An Ideology's Perspective as an Alternative to That of National Cinema. Arts 8: 1. [CrossRef]

Dew, Oliver. 2016. Zainichi Cinema Korean-in-Japan Film Culture. Cham: Springer International Publishing.

Dorman, Andrew. 2016. Paradoxical Japaneseness Cultural Representation in 21st Century Japanese Cinema. London: Palgrave Macmillan.

Elsaesser, Thomas. 1989. New German Cinema: A History. Hampshire: British Film Institute.

Ezra, Elizabeth, and Terry Rowden. 2006. General Introduction: What is Transnational Cinema? In Transnational Cinema: The Film Reader. Edited by Elizabeth Ezra and Terry Rowden. London: Routledge, pp. 1-12.

Fisher, Austin, and Iain Robert Smith. 2020. Transnational Cinemas: A Critical Roundtable. Frames Cinema Journal. Available online: https:/framescinemajournal.com/article/transnational-cinemas-a-critical-roundtable/\#_ ftnref14 (accessed on 27 March 2020).

Frisch, Simon. 2019. The Aesthetics of Flow and Cut in the Way of Film: Towards Transnational Transfers of East Asian Concepts to Western Film Theory. Arts 8: 119. [CrossRef]

Galt, Rosalind, and Karl Schoonover. 2010. Introduction: The Impurity of Art Cinema. In Global Art Cinema: New Theories and Histories. Edited by Rosalind Galt and Karl Schoonover. Oxford: Oxford University Press, pp. 3-29.

Gerow, Aaron. 1993. Celluloid Masks: The Cinematic Image and the Image of Japan. Iris 16: 23-36.

Higbee, Will, and Song Hwee Lim. 2010. Concepts of Transnational Cinema: Towards a Critical Transnationalism in Film Studies. Transnational Cinemas 1: 7-21. [CrossRef] 
Higson, Andrew. 1989. The Concept of National Cinema. Screen 30: 36-46. [CrossRef]

Hjort, Mette. 2010. On the Plurality of Cinematic Transnationalism. In World Cinema, Transnational Perspectives.

Edited by Nataša Durovicová and Kathleen Newman. London: Routledge and American Film Institute Reader, pp. 12-33.

Iwamoto, Kenji. 1993. Japanese Cinema Until 1930: A Consideration of its Formal Aspects. Iris 16: 9-23.

Kawashima, Kentaro. 2019. Metamorphosis as Origin-Koji Yamamura's Short Animation Franz Kafka's A Country Doctor. Arts 8: 54. [CrossRef]

Kirsch, Griseldis. 2019. Gendering the Japanese Empire: Ri Kōran as 'Transnational' Star? Arts 8: 153. [CrossRef]

Kō, Mika. 2009. Japanese Cinema and Otherness: Nationalism, Multiculturalism and the Problem of Japanesenesss. London: Routledge.

Lau, Jenny Kwok Wah. 2002. Multiple Modernities: Cinemas and Popular Media in Transcultural East Asia. Philadelphia: Temple University Press.

Martinez, Dolores P. 2018. From 'Scottish' Play to Japanese Film: Kurosawa's Throne of Blood. Arts 7: 50. [CrossRef]

Mestre Pérez, Rosanna. 2018. Japan in Spain. Japanese Culture through Spanish Eyes in the Film Gisaku. Arts 7: 93. [CrossRef]

Miyao, Daisuke. 2007. Sessue Hayakawa: Silent Cinema and Transnational Stardom. Durham: Duke University Press. Miyao, Daisuke. 2017. Chapter 3: À Travers: The Cinematography of Depth in Japan. In Transnational Cinematography Studies. Edited by Lindsay Coleman, Daisuke Miyao and Roberto Schaefer. Lanham: Lexington Books, pp. 55-75.

Miyao, Daisuke. 2019. How can we talk about 'transnational' when we talk about Japanese cinema? Journal of Japanese and Korean Cinema 11: 109-16. [CrossRef]

Muñoz-Garnica, Miguel. 2018. Intertextuality and Mise en Abyme in Nobuhiro Suwa's H Story and A Perfect Couple. Between European Modernity and Japan. Arts 7: 57. [CrossRef]

Naficy, Hamid. 2001. An Accented Cinema: Exilic and Diasporic Filmmaking. Princeton: Princeton University Press. Nagib, Lucia. 2019. Impure Cinema Intermedial and Intercultural Approaches to Film. London: I.B. Tauris.

Petty, Sheila, ed. 2008. Contact Zones: Memory, Origin, and Discourses in Black Diasporic Cinema. Detroit: Wayne State University Press.

Schoneveld, Erin. 2019. Naomi Kawase's "Cinema of Place". Arts 8: 43. [CrossRef]

Shaw, Deborah. 2013. Deconstructing and Reconstructing Transnational Cinema. In Contemporary Hispanic Cinema: Interrogating the Transnational in Spanish and Latin American Film. Edited by Stephanie Dennison. Woodbridge: Tamesis.

Tezuka, Yoshiharu. 2011. Japanese Cinema Goes Global: Filmworkers' Journeys. Hong Kong: Hong Kong U.

(C) 2020 by the authors. Licensee MDPI, Basel, Switzerland. This article is an open access article distributed under the terms and conditions of the Creative Commons Attribution (CC BY) license (http://creativecommons.org/licenses/by/4.0/). 

Article

\title{
Introduction. The Misleading Discovery of Japanese National Cinema
}

\author{
Marcos P. Centeno-Martín \\ Department of Cultures and Languages, School of Arts, Birkbeck, University of London, \\ London WC1E 7HX, UK; m.centeno@bbk.ac.uk
}

Received: 18 September 2018; Accepted: 9 November 2018; Published: 26 November 2018

\begin{abstract}
The Western 'discovery' of Japanese cinema in the 1950s prompted scholars to articulate essentialist visions understanding its singularities as a result of its isolation from the rest of the world and its close links to local aesthetic and philosophical traditions. Recent approaches however, have evidenced the limitations of this paradigm of 'national cinema'. Higson (1989) opened a critical discussion on the existing consumption, text and production-based approaches to this concept. This article draws on Higson's contribution and calls into question traditional theorising of Japanese film as a national cinema. Contradictions are illustrated by assessing the other side of the 'discovery' of Japanese cinema: certain gendaigeki works that succeeded at the domestic box office while jidaigeki burst into European film festivals. The Taiyōzoku and subsequent Mukokuseki Action films created a new postwar iconography by adapting codes of representation from Hollywood youth and western films. This article does not attempt to deny the uniqueness of this film culture, but rather seeks to highlight the need to reformulate the paradigm of national cinema in the Japanese case, and illustrate the sense in which it was created from outside, failing to recognise its reach transnational intertextuality.
\end{abstract}

Keywords: national cinema; transnational Japanese film; taiyōzoku; mukokuseki; 'kimono effect'; youth icons; postwar film festivals

\section{Introduction}

Since the postwar discovery of Japanese cinema in Western Europe and the U.S., there has been a tendency to define it as an example of national cinema through essentialist visions, understanding its uniqueness as a result of its isolation from the rest of the world. There are two methods for establishing a coherent imaginary of national cinema: First, looking outward, beyond its borders, comparing it to other cinemas, highlighting its difference and considering it in terms of its degrees of otherness. This approach was generally applied in terms of opposition to Hollywood in order to assess how 'national cinema' challenges the institutional mode of representation. ${ }^{1}$ This was the approach that dominated scholarly works until the 1980s; trying to create a sense of national 'identity' through films. The second is carried out through an inward-looking kind of introspective analysis of this cinematic culture, exploring the circumstances of production. National cinema is assessed in relation to its local aesthetic and philosophical traditions, and authors interrogate how and if it reflects the nation itself

1 Term coined by Noël Burch in his well-known Praxis du cinéma (1969) as the dominant mode of filmmaking developed by Hollywood studios and converted into the worldwide norm from the 1920 s, whose aim is creating a totalizing illusionistic representation in which the audience is completely involved in the film through a spectatorial process of identification. Kenji Mizoguchi's long takes, wide shots and off-centred compositions, as well as Yasujirō Ozu's empty spaces and low camera, were seen as epitomes of national cinema. 
and mirrors its cultural heritage. This academic stream tends to focus on films as an unequivocal result of the context in which they are made. ${ }^{2}$

However, cinema has been international since its inception, and assessing these cultural products, either as a result of a creative or an industrial process, within the boundaries of their national borders, is always controversial. This problem has become more evident in recent years. In an increasingly interconnected world, scholars have pinned down the limitations of earlier approaches and are proposing new methodologies that are calling into question the paradigm of 'National Cinema'. This theoretical framework is grounded on an unstable concept: what are we talking about when we talk about national cinema? Is it the group of films produced by a local film industry? Are they those films watched within a domestic market? Do these films represent the culture of a nation? While Japanese cinema in general may fit within the different approaches to 'national cinema', this article seeks to demonstrate how all of them have significant inconsistencies, unless theoretical methodologies are reformulated through the incorporation of a transnational dimension.

In the late 1980s, Higson (1989) opened an enriching discussion posing essential questions to start dealing critically with the paradigm of National Cinema, noting that there is no universally accepted discourse for defining this concept. This idea started to be used in the context of the growing awareness of the auteur figure from the late 1950s that seemed to lead those New Waves in several parts of the world articulating an alternative to Hollywood. This criticism-led approach described by Higson could be regarded as one reducing national cinemas to arthouse, modernist, avant-garde, and quality films. It became useful for critics to describe film movements such as German Expressionism, French Surrealism, Italian Neorealism or Japanese Nūberubāgu. Stephen Crofts also adopted this approach, stating that the true national cinema is the one that resists or ignores the institutional mode of representation (Crofts 1993, pp. 49-67). However, this method presents a twofold inconsistency: First, it neglects the fact that key films and filmmakers often used as representatives of certain national cinemas do not necessarily reject Hollywood patterns of representation. For example, Mizuguchi and Ozu developed their singular 'classic style' only after adopting significant Hollywood practices. Second, contributions from cultural studies (Bourdieu 1993, pp. 29-74) have helped film theorists to understand that the differences between author cinema linked to high culture and commercial cinema related to popular culture are blurred.

The author who categorically defended the specificity of Japanese cinema as a National Cinema, Noël Burch, explains in his well-known work To the Distant Observer that this film corpus is the result of a cultural practice emerging from a tradition that challenges Western patterns of representation (Burch 1979, pp. 67-74). Burch noted that Japanese filmmakers did not follow Western cannons, and instead, seemed to evolve from their own cultural referents. Thus, this work proposed a 'turn to the Orient' that consisted of interrogating those aesthetic and philosophical developments that differed from those evolved in the West, a methodology also applied by Bordwell and Thomson (1976). ${ }^{3}$ They were major contributions, since they highlighted the value of Japanese cinema as opposed to those critics who lamented its apparent delay in adapting Western narrative codes, although these ideas also brought some paradoxes, such as describing Ozu and Mizoguchi's classicism as modernist because it did not fit within Western aesthetic and narrative development. Burch's work, in line with other influential works, such as that of Barthes (1984), was also key to defying the Eurocentrism pervading Western studies in Japan because it analysed its cultural products in close relation to the context of their creation. This was crucial for overcoming the initial analysis of Japanese films as

2 Thus, Mizoguchi's representation of self-sacrificing women have been assessed in relation to the Japanese concept of shibui (melancholy + serenity), his off-centred shots can be explained with the concept of kire-tsuzuki ('cut') theorised by Ōhashi (1994) and Ozu's depiction of the cycles of life, silence, and emptiness are analysed using elements from Zen Buddhism and Japanese cultural and literary tradition such as the mujō ('awareness of impermanence'), mono no aware ('pathos of things') or $m u$ ('emptiness') (see Bordwell 1988; Desser 2006).

3 Also in Bordwell, Ozu and the Poetics of Cinema. 1988. 
dominated by a feeling of estrangement experienced by 'distant observers'. However, theories on Japanese film should be developed without neglecting interactions between the local and the global, as Burch himself noted:

There is an awkward problem which the observer of Japanese things must confront. It is one to which we have already alluded in its ideological formulation: the uniquely Japanese faculty for assimilating and transforming elements 'borrowed' from foreign cultures. To my knowledge, no substantial effort has yet been made in the West to define or analyse this phenomenon, though it has often been commented upon (Burch 1979, p. 89).

Burch suggests that studying the coexistence of 'foreign influence' and 'Japanese uniqueness' by putting them into dialogue might be an enriching method to assess the nature of Japanese films in depth. Although this point was never developed in his book, Burch opens interesting possibilities for studying Japanese specificity from its singular adaptation of Western codes.

\section{The 'Kimono Effect'}

Higson identifies another interesting approach to national cinema; a 'consumption-based' definition in which the major concern is which films audiences watch (1989: 39). However, this perspective presents important contradictions, as the paradigm of 'national cinema' is sometimes grounded in films that are mainly watched abroad. Elsaesser (1989) already addressed this problem from the European context, showing that New German Cinema was more coherent outside than inside Germany, where it only reached $8 \%$ of the audience. Aspects of this national history were well received by foreign audiences-such as Nazism and war topics-, while domestic audiences preferred socially concerned films on topics like feminism, regionalism, and oppressed minorities, which were covered by television reportages in other countries.

Similarly, the idea of Japanese Cinema as a National Cinema started to be articulated in the postwar period through films that were being exported overseas. Therefore, the contradiction presented by Elsaesser is extremely useful for assessing how the theorising of Japanese National Cinema was articulated from the 'Western discovery' of Japanese films during the burst in European film festivals in the 1950s. This phenomenon started with Akira Kurosawa's Rashomon winning the Golden Lion at the Venice Film Festival and an Academy Award in 1951. The same year, Kōzaburō Yoshimura's The Tale of Genji (Genji monogatari) was nominated in Cannes and won the prize for the best cinematography in Venice. The following year marked the discovery of another early master, Kenji Mizoguchi, who received several prizes in Venice: the Golden Lion for The Life of Oharu (Saikaku ichidai onna, 1952), Silver Lion for Tales of Ugetsu (Ugetsu monogatari, 1953) and the same prize for Sansho the Bailiff (Sanshō dayū, 1954). Mizoguchi also obtained three nominations for Best Film; one in Cannes for The Crucified Lovers (Chikamatsu monogatari, 1955) and two in Venice for Princess Yang Kwei-Fei (Yokihi, 1955) and Street of Shame (Akasenchitai, 1956). Kurosawa returned to Venice with The Seven Samurai (Shichinin no samurai, in 1954), which won the Silver Lion and also two Oscar nominations. Teinosuke Kinugasa, who had presented his avant-garde film Crossways (Jüjiro, 1928) in Europe in the late-1920s, received the Grand Prize award at the Cannes Film Festival and two Oscars for Gate of Hell (Jigokumon in 1953). In 1958, Tadashi Imai obtained the Golden Bear at the Berlin Film Festival with The Rickshaw Man (Muhomatsu no issho, 1958), while Eisuke Takizawa obtained a nomination for The Temptress and the Monk (Byakuya no Yōjo, 1958).

The success of Rashōmon and Gate of Hell in the Academy Awards also triggered a growing interest in Japanese films among the American audience. The American Annual Variety's Film Review included comments on Keigo Kimura's Beauty and the Thieves (Bijo to Tōzoku, 1952), a version of a Kabuki play set in the 11th century, and Noboru Nakamura's Adventure of Natsuko (Natsuko no bōken, 1953), 
an adaptation of a Yukio Mishima novel. ${ }^{4}$ Another film set in the Japanese legendary past was Hiroshi Inagaki's Samurai (1954), which obtained an Oscar for Best Foreign Language Film in 1955. ${ }^{5}$

However, Giuglaris and Giuglaris (1957), who were film critics working in Japan in the 1950s, point out a paradoxical fact: the films just mentioned, which were receiving awards in the West, were being substantially unsuccessful in Japan. Even if Rashōmon received two awards in Japan and was listed as the 5 th best film of 1950, most of the Japanese critics disliked the film as it was regarded as a bombastic, incomprehensible, and unrealistic work by Japanese critics. It was not even considered a B Grade film (1957: 27). Months after winning the Golden Lion in Venice, it was released again in Japan and the Giuglares witnessed Japanese audience's disappointment after the screening. Their book includes quotations from viewers showing their incredulity saying that they could not believe that this film had been granted an award by a foreign jury. Something similar happened with The Gate of Hell, which was not even included in the best 10 of that year. In fact, four months after its success in Cannes, it was a resounding failure at the Japanese box office.

What sort of mysterious phenomenon was taking place, according to which unnoticed films in Japan were becoming so successful in the West? After a brief overview of the Japanese films that had triumphed in Europe and the U.S., one common element seems clear: all of them were jidaigeki or 'period films' and presented a legendary Japan stuck in its traditional culture. While jidaigeki seems to have fascinated Western spectators, this genre had been particularly promoted alongside the rise of militarism from the 1930s and presumably Japanese audiences were no longer attracted by this theme in the postwar period. Also, Bordwell (1994) proposed another hypothesis; that these films projected such a high exoticism that not even the Japanese could identify with it.

Nevertheless, this did not happen by chance; it was a consequence of a policy deliberately designed by Japanese Studios aimed at astonishing foreign audiences with exotic images of a distant country. Therefore, they promoted what Antonio Weinrichter (2002) coined the 'kimono effect'; the astonishment of Western audiences by the exoticism projected in Japanese films. As a consequence, it cannot be said that works screened at European festivals were in accordance with the general taste in Japan. To a great extent, films distributed in Europe and the U.S. belonged to Daiei productions. Unlike the other big five studios of the 1950s, Daiei had no distribution network and barely owned theatres for exhibition. The latter, particularly, had no choice but to develop a policy oriented towards foreign exportation. As the president of Daiei, Masaichi Nagata, acknowledged:

The ideal solution to Japanese Cinema is conquering the American market. That's not an easy task. Experience has shown us that European films have never made much of an impact [on the] North American market. That must be taken into account. We carefully studied international markets and then we noticed that the weak point was in the European countries. It was then that we decided to launch historical, traditional, exotic films to be submitted in their festivals, mainly Venice and Cannes. (Giuglaris and Giuglaris 1957, p. 32. My translation)

This question makes theorising Japanese cinema highly problematic, as it was based on a fragmented view of its film heritage which had been cherry-picked to astonish audiences in the West. This brings to the fore how, ironically, the idea of national cinema ended up being constructed from the outside. In this sense, Yamamoto (1983) pointed out that it was the American critic Richie (1974) who first named Ozu as the 'most Japanese' of Japanese directors. It is important to note that this imaginary was created ignoring the complexity of transcultural interactions. For example, Isolde Standish noted that while Ozu's evocation of the 'ephemeral' has been linked to the notion of mono no aware ('pathos of things') of the Heian period in the ninth century, it is in fact a modern

4 Cfr. Variety's Film Review, R. Bowkers, New York, 22-10-1952.

5 Also in Bordwell, Ozu and the Poetics of Cinema. 1988. 
reappropriation resulting from the new ways of fragmenting and reordering the world brought by the cinematic technology imported from the West at the turn of the twentieth century (Standish 2012, p. 6). Yamamoto (1983) had opened the possibility of analysing the mutual influence of East and West on each other's films, which can be traced back even among the filmmakers that had been chosen to epitomize the uniqueness of Japanese cinema. In fact, the most outstanding works by Kurosawa were inspired by moral and philosophical conflicts depicted in Western literature: his Ran (1985) was an adaptation of William Shakespeare's "King Lear", Throne of Blood (1957) was a film version of "Macbeth"; Leo Tolstoy's "The Death of Ivan Ilyich" inspired his Ikiru (1952), and Seven Samurai (Shichinin no samurái, 1954) is a loose adaptation going back to the Ancient Greek play "Seven Against Thebes" by Aeschylus.

In addition, Mizoguchi became one of the main representatives of Japanese cinematographic classicism alongside Yasujirō Ozu. However, we should not forget that in the 1920s Ozu and Mizoguchi belonged to a group of filmmakers seeking to modernise cinema by adapting Western modes of representation. Foreign filmmakers such as Fritz Lang, F.W. Murnau, Ernst Lubitsch, Josef von Sternberg and Erich von Stroheim had a significant impact on them as their films were imported to cover the lack of new releases after the Great Kantō earthquake of 1923. For instance, Ozu and Mizoguchi opposed the use of onnagata, men playing female roles, inherited from the tradition of Kabuki theatre and also rejected the use of benshi, narrators during the screenings. Benshi invented dialogues and interpreted films according to their will in order to fix meanings and avoid manipulations, both filmmakers added intertitles, which was a clear sign of Western influence during the silent era.

\section{Imagining a 'Nation'}

There is another way to address the issue of National Cinema, which Higson defines as the 'text-based' approach, focusing on narrative and aesthetic aspects (1989: 43). This methodology can be developed in two directions. One would be grouping films that share a common style or formal systems of representation that work as an allegory of a national culture. However, this tendency was based on a structural problem: understanding Japanese cinema as if it were a unified text, ignoring the plurality of narrative patterns and historical stages. This approach was already called into question by Bock (1984), who tried to categorise distinctive periods in the history of Japanese Cinema as 'Early Masters', 'Postwar Humanists' and the 'New Wave'. One decade later, Desser (1988) confirmed the distinction, while introducing the concept of 'dominant paradigms' rather than historical periods, given that classical Early Masters' Classicism, Modern Postwar Humanism and Modernist New Wave were simultaneous during certain periods of time.

Another direction that the text-based approach may take is gathering those films projecting an alleged idea of a Nation. These studies explore to what extent cinema is engaged in constructing a sort of national identity. The main weakness of this method is mistakenly considering that national cinema has provided unproblematised imagery of nationhood, neglecting any ethnic, social, cultural, or sexual diversity. The 19th-century definitions of a nation based on communities apparently sharing a certain language, religion, and folkways have been called into question by recent approaches. As Giddens (1990, p. 65) argues, the creation of a 'national identity' is one of the consequences of modernity as we see increasing pressure for erasing regional cultural diversity to strengthening boundaries within the national borders. To articulate a bounded geo-political entity it was necessary to facilitate, in Anderson Benedict's terms, the 're-imagining of communities' as factitious entities that would fit in the idea of the modern nation-state (Anderson 1991, pp. 204-6).

Cinema played a major role in the dissemination of these national entities. However, while some films may be seen as a result of a millenary philological and aesthetic tradition, others can only be explained by calling this tradition into question. In other words, some films are precisely made as a response to rather than as a result of their cultural background. For example, some authors transgress normative sexuality, such as Toshio Matsumoto's representation of transexuality in Funeral Parade of Roses 
(Bara no Sōretsu, 1969) and Nagisha Oshima's challenge to heteronormative gender roles pervading samurai films with the depiction of homosexual love in Taboo (Gohato 1999). Other works have challenged the idea of 'Japaneseness' from an undefined space that hardly fits within the paradigm of national cinema. For instance, I have written elsewhere on the representation of the minority of Ainu people by foreign authors in works mainly aimed at the Western audience, such as the early Lumière brothers' actualités, Benjamin Brodsky’s travelogues (Centeno Martín 2017) and Neil Gordon Munro's ethnographic documentaries (Centeno Martín 2018). Other examples may be found in films made by Zainichi about Korean residents living in Japan such as Yang Young-Hee's Dear Pyongyang (2006). Not less important are the critical voices raising contradictions regarding the continuity of the Imperial Household in the postwar democracy. Fumio Kamei attacked the tennō sei ('Emperor system') that had been used to legitimise the authority of the Emperor from Meiji Restoration by addressing the question of responsibility in World War II in The Japanese Tragedy (Nihon no higeki, 1946). Along the lines, the taboos related to war responsibility and the atrocities perpetrated by the Japanese Imperial Army are tackled by Kazuo Hara in The Emperor's Naked Army Marches On (Yuki Yukite Shingun, 1987). Additionally, hegemonic discourses of the nation are challenged by films such as The Insect Woman (Nippon Konchūki, 1963) and History of Postwar Japan as Told by a Bar Hostess (Nippon Sengoshi-Madamu onboro no Seikatsu, 1970), in which Shōhei Imamura rejects the hegemonic discourses on the history of postwar Japan as told from the male elites of the country and instead decides to narrate it from the point of view of female outcasts who are prostitutes or burakumin — cast of the untouchables.

In his criticism of seeing films as a mirror of a nation, Higson noted that while the paradigm of National Cinema may be helpful for labeling films, it is a dangerous tautology that necessarily fails to reflect the diversity of every society (2000: 63-74). Film representations of a nation draw on an 'imagined community' which is often demarcated in a limited geographical space inhabited by an apparent unified people. This ideological construction has perpetuated an artificial imagination alongside nationalist discourses that always try to repress the complexity that shapes every society. Thus, films tend to project a homogeneous community which needs to be coherent with stereotypes, national myths and what is considered part of the traditional culture, therefore articulating an image that is too simplistic and, as a consequence, necessarily wrong. A more comprehensive approach to national cinema should take into account those examples presenting resistance to predominant discourses and including these stories of crisis and negotiation of the idea of nation.

Higson (2000) proposes that films on and made by Diasporas revisit the idea of 'community' and he uses them to maintain that national categorizations should be replaced with a transnational perspective. This proves to be a helpful epistemological tool to determine how cinematic productions are unavoidably hybrid cultural forms. From the early 2000s, the global world and the increasingly international production and circulation of films have prompted scholars to seek new theoretical frameworks along these lines. Mette Hjort (2010, pp. 12-33) expands the transnational, claiming that it must be applied to wider aspects of production, distribution, and reception. She provides a useful typology of 'cinematic transnationalism' to assess contemporary film phenomena. Simultaneously, Higbee and Song (2010, pp. 7-21) advocate new approaches for the study of East Asian cinemas by incorporating a 'critical transnationalism' in film studies. Miller (2001) marked a departure from earlier paradigms, using World Cinemas as a rubric, with strong intellectual allegiances to Area Studies, collectively grouping films from non-Western geographies. Harootunian and Miyoshi (2002) argued that Area Studies in general had collapsed in the 1990s, stating that the fall of the Berlin Wall triggered the end of geographical locations as sufficient criteria in themselves for academic research. This marked the emergence of 'Global Cinema' Studies in the 21st century. These contributions have also been essential to overcoming the difficulties of defining 'national cinema' in economic terms (Higson 1989, p. 38), establishing a correspondence with its domestic film industry. In recent years, key figures of the cinematographic scene in Japan would fall out of this category. For example, Takeshi Kitano's Brother (2000) is a U.S.-Japan coproduction; Hideo Nakata's The Ring 2 (2005) was made in the U.S.; 
Shunji Iwai's Vampire in Canada; and Hayao Miyazaki's Spirited Away was distributed worldwide by Walt Disney Pictures.

\section{Cultural Products beyond National Boundaries}

Despite its contradictions, this text-based approach has triggered a long discussion since the influential Kracauer (1947) proposed a study of cinema as a cultural expression of a nation. Through his analysis of Robert Wiene's The Cabinet of Dr. Caligari, Kracauer claimed that the film anticipated the rise of Nazism in Germany and explained how films can project the anxieties, fears, and daydreams of a society in which they are made. Soon after that, Sadoul (1966) revitalised this tendency, stating that nation and people are the material on which a great number of films are based. More recently, a semiotic approach prompted by Stephen Prince and Philip Rosen has linked cinema to a national culture through a 'culturalism' in film studies that is described by Bordwell and Carroll (1996). These authors discuss the necessity of studying where and when cultural parameters produce meaning on cinematographic images. Prince claims that every discourse, either linguistic or cinematographic, is culturally set, and as a result, concludes that systems of signs do not produce meaning outside a cultural and social context (Prince 1991, p. XV). ${ }^{6}$ Rosen takes Kristeva's notion of intertextuality to delimit national cinema as a coherent corpus of films that produce certain insight into a given local culture (Rosen 1984, pp. 17-28). To form a national cinema, it would be necessary for a given nation to have a sound film production, with enough historical weight to be able to create its own cinematic macro-discourse. Thus, the existence of a national cinema would depend on the consistency of a shared imaginary and its own referential universe.

Japanese cinema has often been used as a quintessential example of this theoretical perspective, seeking to justify how it is built on a self-referential universe, dominated by singular narrative and aesthetic conventions. However, this approach presents a structural limitation, only tackling film works from within national borders and neglecting transnational phenomena of a different kind that can be found in film production, distribution, or consumption. Prince ignored that filmmakers' sources of inspiration may be found far from the geographical and cultural context in which films are made. Rosen also reduced the imaginary of a national cinema to local references, a limiting view that does not take into account a wider intertextuality beyond national borders.

\section{Transculturality in the Domestic Market}

In the case of Japanese cinema, its transnational intertextuality was initially obscured by the first views relying on those period dramas that were selected to be exported to the West in the 1950s. However, as we have already seen, they were not particularly successful in the domestic market. How would the theorising of Japanese cinema have changed if it had been founded on those films that were popular in Japan? The following table is quite illustrative for thinking about the kinds of nuances and new questions that would have been added to the paradigm of national cinema.

As we can see, jidaigeki films were far from the trendy genre of that time and their production was greatly below that of gendaigeki or 'contemporary dramas' (see Figure 1). While Western audiences were astonished by exotic images of a feudal Japan of geisha and samurai during the internationalisation of this cinema in the 1950s, the Japanese crowd was fascinated by a different kind of exoticism; the predominance of American popular culture in the new youth cinema (seishun eiga) released at the time. This genre had originally been created by American International Pictures, which discovered the teenage market in the early 1950s. The demography of postwar audience had changed both in the U.S. and Japan. By the mid-1950s, the generation of baby boomers had become a new market for the culture industry. Although at the beginning of the decade Daiei Studios had already started creating contents for the teenage ( $j \bar{u} d a i)$ audience, the problem of youth became predominant from the release

6 To know more about this linguistic model applied to images, see (Prince 1993). 
of taiyōzoku films. Nikkatsu, which stopped the production of jidaigeki films in 1958, engaged in the production of films for this new niche market with the taiyōzoku, which literarily means 'Tribe of the Sun', a group of films released in the summer of 1956.

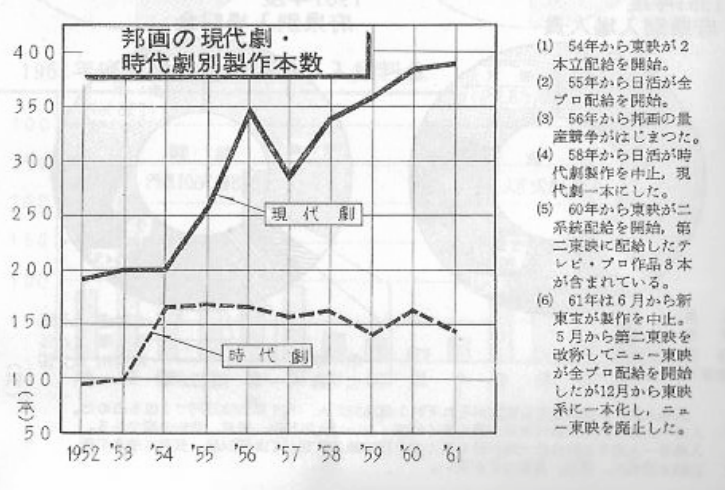

Figure 1. Production of gendaigeki (contemporary dramas) (continuous line), and jidaigeki (period dramas) (discontinuous line), between 1952 and 1961. Source: Vv 1963. Eiga nenkan. Tokyo: Jijitsūshinsha, p. 36.

The first one, Takumi Furukawa's Season of the Sun (Taiyō no kisetsu, 1956), is based on Shintarō Ishihara's eponym short novel, published the previous year. The film provided a form of escapism portraying the bourgeois lives of university youngsters from high-class families living in posh residential areas along the Shōnan Coast. After its success, Daiei tried to take advantage of this phenomenon with the adaptation of another novel by Shintarō Ishihara, Punishment Room (Shokei no heya), directed by Kon Ichikawa and released in June. Additionally, Nikkatsu hurried to make its second film, Kō Nakahira's Crazed Fruit (Kuruta Kajitsu), which was released in July and made Yūjirō Ishihara an icon of Japanese popular culture at the time. In August, this company released Takumi Furukawa's Backlight (Gyakkōsen), an adaptation of a novel by the female writer of youth literature, Kunie Iwahashi. Eventually, Tōhō also joined the taiyōzoku phenomenon with the production of Hiromichi Horikawa's Summer in Eclipse (Nisshoku no natsu), released in September and starring Shintarō Ishihara himself, whose Western looks and hairstyle made a great impact among the young audience. The Californian look of taiyōzoku characters, with sun glasses, baggy trousers and Hawaiian shirts was reminiscent of Marlon Brando's style in The Wild One (László Benedek, 1953) and James Dean's in Rebel Without a Cause (Nicholas Ray, 1955). ${ }^{7}$ These films were aimed at a new generation who had left behind the hardships of the immediate postwar and was increasingly exposed to the iconography and values projected by the American popular culture. Thus, these youth icons were often featured on screen driving convertible cars and engaging in new forms of entertainment, such as sailboats, water skiing, boxing, and jazz clubs. Critics of the time complained that the portrayal of youth in novels and films was not a faithful representation of its social reality (Endō 1955, p. 118; Mashita 1956, pp. 88-98; Nakaya 1956, pp. 21-24; Takeuchi 2003, p. 80). More recently, scholars have interrogated how these characters created a transcultural iconicity that somewhat conveyed the anxieties, daydreams, inferiority complexes, and aspirations of the postwar youth (Galbraith and Dundan 2009; Schilling 2007; Raine 2000; Centeno Martín 2016).

7 Stars like Hiroshi Kawaguchi, the protagonist of Punishment Room, constantly asked the hairdresser for a 'James Dean style', Shükan Yomiuri, 27 May 1957. 
While the jidaigeki films leading the 'kimono effect' in the West were a failure in Japan, these taiyōzoku films obtained great success at the box office. The three Nikkatsu films, Season of the Sun, Crazed Fruit and Backlight raised $¥ 500$ million; Punishment Room and Summer in Eclipse made around $¥ 150$ million each (Namba 2004, p. 165). Media pressure exerted by the American stars must have been especially intense between 1952 and 1957, a period in which the distribution of foreign films in Japan doubled, rising from 63 to 118 ( $\mathrm{Vv}$ 1963, 35), and the assimilation of these Hollywood codes continued in the films including a juvenile star system created by Nikkatsu in the following years featuring: Yūjirō Ishihara, Akira Kobayashi, Keiichirō Akagi, Kōji Wada and Joe Shishido (see Figure 2), representing a new Japaneseness embodying disconcerting hybrids between Japanese and foreign heroes.

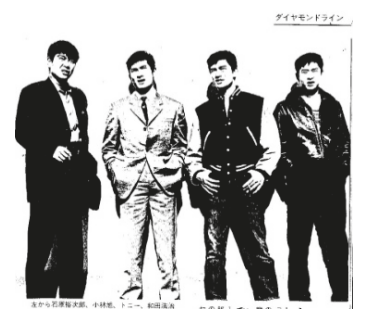

Figure 2. Nikkatsu's 'Diamond Line' poster. From left to right: Yūjirō Ishihara, Akira Kobayashi, Akagi Keiichirō and Koji Wada.

By the end of the 1950s, the so-called 'Second Golden Age' of Japanese cinema was coming to an end due to the competition of a new medium, the television. In 1958, the film industry reached a historical peak of production, with 547 annual releases, meaning that almost two new films were released every single day. However, by the turn of the decade, audiences had started to drop as viewers began to replace the cinema experience with watching films at home. One of the strategies developed by Big Studios was appealing young audiences with films featuring transcultural heroes and projecting exotic images of Japan that somewhat resembled Hollywood blockbusters. Nikkatsu marketed its youth icons under the label of Diamond Line that Nikkatsu used to renew the taiyōzoku with a new kind of film named Mukokuseki Action ('action without nationality'). One of the most representative examples is the Wataridori series (1959-1962), starring Akira Kobayashi, who plays a cultural cross-breed role of 'lone ranger'. These films develop an interesting adaptation of codes from Hollywood westerns, projecting a renewed fusion between the Occident and Japan. The film Plains Wanderer, also known as Rambler Rides Again (Daisogen no wataridori, 1960), directed by Takeichi Saitō, was shot in Hokkaido. Its landscapes imitate those of the Far West in the U.S. Kobayashi is featured with blatant cowboy elements, such as a fringe, a whip and even gestures borrowed from Alan Ladd and John Wayne, including the way of riding a horse. In fact, Kobayashi acknowledged that he had studied Alan Ladd's way of drawing the pistol and John Wayne's use of the rifle (Nishiwaki 2004, p. 152). The story revolves around a fight for the land rights of the Ainu people, whose iconography is a caricature echoing images of the Native American (Watanabe 1978; Centeno Martín 2016, p. 154). There were other examples that illustrate how this transcultural imaginary materialized in Japan in the postwar period. Keiichirō Akagi, nicknamed 'Tony' because of his resemblance to Tony Curtis, plays the role of a hitman wearing a leather jacket in the series Tales of a Gunman (Kenjü buraichō, 1959-1960), which is a reminder of James Dean and Marlon Brando (Nozawa 1997, p. 42). Joe Shishido played characters with a suspiciously foreign air inspired by actors of American B-movies such as those of Timothy Carey, Lee Marvin, and Henry Silva.

These heroes not only imported visual elements from Hollywood, they also embodied deeper moral, ethical, and narrative changes, such as the emphasis on individual liberty that had been legitimized after the Occupation period. Also, Yūjirō appeared on screen playing enka (Japanese ballade) 
with his ukulele and jazz and Japanese popular songs (kayokyoku) with the guitar, piano, and drums. Similarly, Kobayashi and Akagi were often featured playing a guitar in their films. Borders between American and Japanese popular culture were increasingly blurred by the second half of the fifties. These young stars became a kind of actor-singer, such as Elvis Presley, who began his cinema career with Love Me Tender (1956) and Gene Vincent, who debuted with The Girl Can't Help It (1956). These films became a profitable business mainly due to the songs played on screen which became extraordinarily popular, being broadcast on the radio and edited in LPs.

Scholars have questioned the supposed airtightness of Japanese cinematic production in recent years. Authors such as Gregory Barret, Donald Kirihara, David Desser, Michael Raine, Mitsuhiro Yoshimoto, and Aaron Gerow have evidenced that the cinematographic independence of this country is more complex than earlier expected. Its cultural production has unavoidably been traversed by streams coming from abroad. Contradictions in the notion of 'national cinema' can be found from the outset. Even before World War II, Marxists such as Eisenstein, one of the main defenders of Japanese specificity, and Iwasaki (1931), stated that this industry was not alien to the capitalist circumstances found in Europe and the U.S. Also, Junichirō Tanizaki wrote in his In Praise of Shadows (Tanizaki 1933) that cinema had forced him to abandon the Japanese artistic and aesthetic tradition in favour of a Western conception of using light and shadow. It is well known that both Japanese filmmakers and filmgoers had been exposed to foreign films from the beginning of cinema-we mentioned above the influence of German directors on the Japanese early masters. However, it is important to note that the widely spread idea during the postwar period that Japanese film culture was isolated from the rest of the world was highly contradictory, given the unseen number of foreign films being distributed in Japan at the time, as we can see on the following graph (Figure 3).

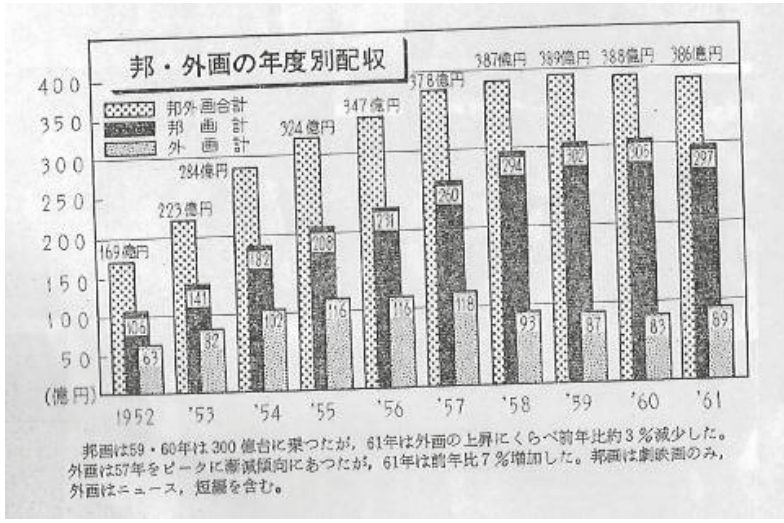

Figure 3. Distribution of Japanese and foreign films in Japan between 1952 and 1961. Grey: National productions. Black: foreign productions. Dotted: total. Vv 1963. Eiganenkan. Tokyo: Jijitsūshinsha, p. 35 .

\section{Conclusions: Reframing Uniqueness through the Transnational}

The examples provided above call into question approaches to Japanese cinema focusing on narrative and aesthetic patterns that are different from those developed in the West. That was the stream triggered by Burch's text which finds a historical reason for this uniqueness: before the surrender in 1945, Japan had never been occupied by a foreign power (1979: 29). The country was free from a semi-colonial status such as that of China, or total dependence such as that of India, and as a consequence, its prolific film industry was able to consolidate completely original and autochthonous means of representation. Nygren (2007) also supported this statement by claiming that Japanese originality was achievable thanks to the technical and economic autonomy of its film 
industry. Indeed, operators were trained and films started to be produced locally at a very early stage. In short, the self-sufficiency of its film studios would have allowed an interaction between cinema and its millenarian culture. In order words, Burch and Nygren claimed that the isolation of directors, screenwriters, and operators would have allowed them to make films free from Western influences and linked to their cultural tradition. However, this argument leaves two questions unresolved: First, is the functional autonomy of the Japanese film industry enough to create an essentially national cinema? Second, does this fact guarantee an absence of foreign influences?

This article does not attempt to deny the weight of the singularity of Japanese culture and the weight of its artistic tradition in cinema; but it seeks to highlight the fact that critics and scholars have often tended to neglect the sensitivity of Japanese filmmakers to foreign ideas and practices. The cases posed here show that Japan can and must be studied as an exceptional place for the international flow of images, without that entailing a loss of authenticity as authors in Japan and the West started to note from the 1980s. Yamamoto (1983) opened the discussion by interrogating seriously the impact of foreign influence on Japanese Cinema. This approach was followed by scholars such as Gerow (1993, pp. 23-36; 2010, pp. 1-14), who explains how cinema is a part of the cultural tradition of the 20th century, and full of multiple foreign influences. Similarly, Desser $(1988$, p. 15) defines the Japanese New Wave as part of a movement expanding beyond its national borders. In addition, Barrett (1989) assesses archetypes in Japanese films that go back to folklore, mythology, and literature, while identifying others emerging from a conflict between tradition and modernity and from the interactions with the West.

These authors exemplify a sort of 'post-national' approach to cinema. In this sense, Kirihara (1992) tackles the Japanese specificity warning about the contradictions related to essentialist Orientalism which some national cinema theorists have fallen into Kirihara (1996, pp. 501-19) demonstrates in his study of Mizoguchi that even classicism, which is often used as an example of the national character of the Japanese film, is a place of an extraordinary and rich internationalisation rather than a return to its traditions. As a consequence, we may ask what it is that makes Japanese films Japanese? As we have seen, to a great extent, it seems to be the Western gaze. In light of these contributions, it would be essential to reformulate the paradigm of Japanese national cinema within the global culture of images that flow incessantly. This does not have to undermine the role of Japanese tradition but, on the contrary, these approaches will be helpful to acknowledge and contextualise the Japanese film creation properly in the midst of an amalgam of practices, some from remote times and others from remote geographies.

Funding: This research was funded by The Daiwa Anglo-Japanese Foundation grant number [Ref. 197/13307].

Conflicts of Interest: The author declares no conflict of interest.

\section{References}

Anderson, Benedict. 1991. Imagined Communities. London and New York: Verso.

Barthes, Roland. 1984. L'Émpire des signes. París: Flammarion.

Barrett, Gregory. 1989. Archetypes in Japanese Film. The Sociopolitical and Religious Significance of the Principal Heroes and Heroines. London: Associated University Press.

Bock, Audie. 1984. Japanese Film Directors. New York: Kodansha International.

Bordwell, David, and Kristin Thomson. 1976. Space and Narrative in the Films of Ozu. Screen 17: 41-73.

Bordwell, David. 1988. Ozu and the Poetics of Cinema. Princeton: Princeton University Press.

Bordwell, David. 1994. Film history: an Introduction. New York: McGraw Hill.

Bordwell, David, and Noël Carroll, eds. 1996. Post-Theory: Reconstructing Film Studies. Madison: University of Wisconsin Press, pp. 1-4.

Bourdieu, Pierre. 1993. The Field of Cultural Production. New York: Columbia University Press, pp. $29-74$.

Burch, Noël. 1979. To the Distant Observer: Form and Meaning in the Japanese Cinema. Berkeley: University of California Press. 
Centeno Martín, Marcos P. 2016. Transcultural Corporeity in Taiyōzoku Youth Cinema. Some Notes on the Contradictions of Japaneseness in the Economic Miracle. In Körperinszenierungenimjapanischen Film/Presentation of Bodies in Japanese Films. Edited by Andreas Becker and Kayo Adachi-Rabe. Frankfurt: Goethe-Universität Frankfurt, Darmstadt: Büchner-Verlag, pp. 143-60.

Centeno Martín, Marcos P. 2017. Failures of the Image: Backstage Look at the Early Film Portrayals of the Ainu People. Orientalia Parthenopea 17: 189-210.

Centeno Martín, Marcos P. 2018. Contextualising N. G. Munro's filming of the Ainu Bear Ceremony. Japan Society Proceedings. pp. 90-106. Available online: http://eprints.soas.ac.uk/id/eprint/25733 (accessed on 20 November 2018).

Crofts, Stephen. 1993. Reconceptualizing National Cinema/s. Quarterly Review of Film and Video 14: 49-67. [CrossRef]

Desser, David. 1988. Eros Plus Massacre: An Introduction to The Japanese New Wave Cinema. Bloomington: Indiana University Press.

Desser, David. 2006. A Filmmaker for all Seasons. In Asian Cinemas: a Reader and Guide. Edited by Dimitris Eleftheriotis and Gary Needham. Honolulu: University of Hawai'i Press, pp. 157-65.

Elsaesser, Thomas. 1989. New German Cinema: A History. Hampshire: British Film Institute.

Endō, Shūsaku. 1955. Taiyo no kisetsuron. Ishihara Shintarō he no kugen. Bungakkai 11: 118.

Galbraith, Stuart, and Paul Dundan, eds. 2009. La tribu du soleil et la nouvelle vague. InLe cinéma japonais. Hong Kong: Taschen.

Gerow, Aaron. 1993. Celluloid Masks: The Cinematic image and the Image of Japan. Iris 16: 23-36.

Gerow, Aaron. 2010. Introduction: The Theory Complex. Review of Japanese Culture and Society 22: 1-14.

Giddens, Anthony. 1990. The Consequences of Modernity. Cambridge: Polity Press.

Giuglaris, Shinobu, and Marcel Giuglaris. 1957. Le cinema Japonais. Paris: du Cerf.

Harootunian, Harry D., and Masao Miyoshi. 2002. Learning Places: The Afterlives of Area Studies. Durham: Duke University Press.

Higbee, Will, and Hwee Lim Song. 2010. Concepts of transnational cinema: towards a critical transnationalism in film studies. Transnational Cinemas 1: 7-21. [CrossRef]

Higson, Andrew. 1989. The Concept of National Cinema. Screen 30: 36-46.

Higson, Andrew. 2000. The Limiting Imagination of National Cinema. In Cinema and Nation. Edited by Mette Hjort and Scott MacKenzie. London and New York: Routledge, pp. 63-74.

Iwasaki, Akira. 1931. Eiga to shihonshugi [Cinema and Capitalism]. Tokyo: Ōraisha.

Kirihara, Donald. 1992. Patterns of Time: Mizoguchi and the 1930s. Madison: University of Wisconsin Press.

Kirihara, Donald. 1996. Reconstructing Japanese Film. In Post-Theory: Reconstructing Film Studies. Edited by David Bordwelland Noël Carroll. Madison and London: University of Wisconsin Press, pp. 501-19.

Kracauer, Siegfried. 1947. From Caligari to Hitler: A Psychological History of the German Film. 2985 edition. Princeton: Princeton University Press.

Mashita, Shinichi. 1956. Nihon no seishun. Seinentachi no kirokuyori [Japanese Youth. Fromthe Record of Youth]. FujinKōron 41: 88-94.

Miller, Toby. 2001. Global Hollywood. London: BFI Publishing.

Nakaya, Ukichiro. 1956. Taiyōzoku no jidaisō [TaiyōzokuStages]. Bungakkai 9: 21-24.

Namba, Koji. 2004. Concerning Youth Subcultures in the Postwar Era Vol.1: From Taiyo-zoku to Miyuki-zoku. KwanseiGakuin Sociology Department Studies 3: 163-78.

Nishiwaki, Hideo. 2004. Kobayashi Akira densetsu. KinemaJunpō 14: 150-58.

Nozawa, Kazuma. 1997. Akagi Keiichirō: 'hikari to kage' nijūssai no fināre [Keiichiro Akagi: 'Lights and Shadows' of the Final at 20]. Tokyo: Seisei Shuppan.

Nygren, Scott. 2007. Time Frames. Japanese Cinema and the Unfolding of History. Minneapolis and London: University of Minnesota Press.

Ōhashi, Ryōsuke. 1994. Kire. Das 'Schöne' in Japan [The Beauty in Japan]. Köln: DuMont.

Prince, Stephen. 1991. Introduction. In Explorations in Film Theory: Selected Essays from Cine-Tracts. Edited by Ron Burnett. Bloomington: Indiana University Press, p. XV.

Prince, Stephen. 1993. The Discourse of pictures: Iconicity and film studies. Film Quarterly 47: 16-28. [CrossRef] 
Raine, Michael John. 2000. Ishihara Yūjirō: Youth, Celebrity, and the Male Body in late-1950s Japan. In World and Image in Japanese Cinema. Edited by Dennis Washburnand Carole Cavanaugh. Cambridge: Cambridge University Press, pp. 202-25.

Richie, Donald. 1974. Ozu: His Life and Films. Berkeley: University of California Press.

Rosen, Philip. 1984. History, Textuality, Nation: Kracauer, Burch and Some Problems in the Study of National Cinemas. Iris 2: 17-28.

Sadoul, Georges. 1966. Histoire du cinéma mondial. Paris: Flammarion.

Schilling, Mark. 2007. No Borders, No Limits: Nikkatsu Action Cinema. Godalming: FAB.

Standish, Isolde. 2012. The ephemeral as transcultural aesthetic: A contextualization of the early films of OzuYasujirō. Journal of Japanese and Korean Cinema 4: 3-14. [CrossRef]

Takeuchi, Yō. 2003. kyōijkushugi no botsuraku [The Wreck of Educationism]. Tokyo: Chūōshinsho.

Tanizaki, Junichirō. 1933. Keizai ōrai. Tokyo: Nihon hyōronsha.

Vv, Aa. 1963. Eiga nenkan. Tokyo: Jijitsūshinsha.

Watanabe, Takenobu. 1978. Fujimi no hīrō ni idomuKobayashiAkira no intabyū [Interview to AkiraKobayashi. ChallenginganImmortal Hero]. KinemaJunpō 15: 74-77.

Weinrichter, Antonio. 2002. Pantallaamarilla: el cine japonés. Las Palmas de Gran Canaria: Festival Internacional de Cine. Yamamoto, Kikuo. 1983. Nihon eiga ni okerugaikokueiga no eikyō [The Influence of Foreign Cinema on Japanese Cinema]. Tokyo: Waseda Daigaku Shuppanbu, p. 629.

(C) 2018 by the author. Licensee MDPI, Basel, Switzerland. This article is an open access article distributed under the terms and conditions of the Creative Commons Attribution (CC BY) license (http:/ / creativecommons.org/licenses/by/4.0/). 

Article

\title{
From 'Scottish' Play to Japanese Film: Kurosawa's Throne of Blood
}

\author{
Dolores P. Martinez \\ Emeritus Reader, SOAS, University of London, London WC1H 0XG, UK; dm6@soas.ac.uk \\ Received: 16 May 2018; Accepted: 6 September 2018; Published: 10 September 2018
}

\begin{abstract}
Shakespeare's plays have become the subject of filmic remakes, as well as the source for others' plot lines. This transfer of Shakespeare's plays to film presents a challenge to filmmakers' auterial ingenuity: Is a film director more challenged when producing a Shakespearean play than the stage director? Does having auterial ingenuity imply that the film-maker is somehow freer than the director of a play to change a Shakespearean text? Does this allow for the language of the plays to be changed-not just translated from English to Japanese, for example, but to be updated, edited, abridged, ignored for a large part? For some scholars, this last is more expropriation than pure Shakespeare on screen and under this category we might find Kurosawa's Throne of Blood (Kumonosu-jo 1957), the subject of this essay. Here, I explore how this difficult tale was translated into a Japanese context, a society mistakenly assumed to be free of Christian notions of guilt, through the transcultural move of referring to Noh theatre, aligning the story with these Buddhist morality plays. In this manner Kurosawa found a point of commonality between Japan and the West when it came to stories of violence, guilt, and the problem of redemption.
\end{abstract}

Keywords: Shakespeare; Kurosawa; Macbeth; films; translation; transcultural; Noh; tragedy; fate; guilt

\section{Introduction: 'The Instruments of Darkness Tell Us Truths' (Macbeth)}

At the nineteenth century's end Shakespeare's plays became the subject of filmic remakes, as well as the source for others' plot lines. ${ }^{1}$ Rothwell (1999) claims that this transfer of Shakespeare's plays to film presents a challenge to filmmakers' auterial ingenuity, ${ }^{2}$ a process that began with the first attempts to capture a Shakespearean performance on film. Such a statement raises a variety of questions: Were the very first attempts to film plays - any plays, not just Shakespeare's—already a shift from faithful documentation on film to auterial ingenuity? Why should a film director be more challenged when producing a Shakespearean play than the stage director-does auterial ingenuity imply that the film-maker is somehow freer than the director of a play to change a Shakespearean text? Does it mean that the plays are somehow transformed, translated we might say, from a mode of representation in which a single stage must represent the world to one in which the process allows for all sorts of visual manipulation? Does it allow for the language of the plays to be changed; not just translated from English to Japanese, for example, but to be updated, edited, abridged, ignored for a large part? If the language is so radically altered and the plays updated, are we looking at changes in

1 According to the British Film Institute, the first such adaptation was Sir Herbert Beerbohm Tree's production of King John in 1899 (see: http:/ / www.screenonline.org.uk/film/id/444972/). The Guinness Book of World Records in 2014 named Shakespeare the most filmed author with 410 film adaptations of his works, while in the same year IMDB listed 1095 works that credited William Shakespeare (see: https://stephenfollows.com/movies-based-on-shakespeare-plays /).

2 The use of the term auterial here refers to Truffaut's (1954) argument that a film-maker can a film's author. Truffaut argued that in French cinema, but also in the work of some non-French directors such as Alfred Hitchcock, the vision and purpose of the director dominated the entire process of filming, making them the movie's auteur/author. 
genre, a shift in storytelling style as in the various versions of Macbeth, Othello, and King Lear which recast the narratives as gangster films? For Rothwell (1999), this last is more expropriation than pure Shakespeare on screen and under this category he puts Kurosawa's Throne of Blood (Kumonosu-jō 1957). While this article cannot consider why and how Shakespeare has come to be so durable, cross-cultural, and global, we do need to consider what happens when a work of art transcends its local culture.

To begin with, the potential difference between a filmed version of a play and its live performance must be understood. I use the term 'potential' because the very first versions of Shakespeare on film were often seen as visual recordings (no sound), short clips, of an actor in his greatest role. This trend can still be discerned in television and cinema broadcasts of staged versions, sometimes live, with several cameras used to give the audience some visual variety. Such attempts to capture the power of a live performance were critiqued early on by Benjamin (1973). For Benjamin the charismatic power of a particular performance depended on the actor's aura, a quality he did not see as possible to capture on film. While Benjamin argues that the aura of an actor's performance can get lost in the age of mechanical reproduction, we should be wary of reading this work as a lament for the loss of authenticity, because Benjamin goes on to develop his analysis to note that perhaps something else is happening in a film, something of great importance. The reactions of the audience to the film may well vary, ${ }^{3}$ thus the shift is from a ritualised relationship in which a single performance in a play might dominate, to one that is inherently personal and possibly political: Film allows all viewers to become critics and to have their own relationship with a narrative, including the desire to create one's own story.

Thus, the fact of mass production asks us to have a different relationship with art: Copying or remaking might well be about creating new and different meanings. This is the line pursued by the anthropologist Taussig (1993), and his argument was prefigured by Deleuze and Guattari's (1986) discussion of deterritorialisation and re-assemblage in their long essay on Franz Kafka. For these writers copying and re-assembling are not just about generating faithful reproductions, but also are about the relations of production and the politics of othering. When someone new enters the processes of assemblage and production, their re-assemblage may well result in creative innovation. In other words, Shakespearean screen adaptations not only strive to find new ways of telling an old story, but endeavour to imbue the play with new, contemporary, meanings. If films allow for a myriad of understandings, deeper incursions into the human psyche and the body politic, then achieving that end necessitates pushing film as a medium to its very boundaries. This is a point which Brode (2000) makes in relation to filmed versions of Shakespeare.

Every film version of a Shakespearean play, then, is much more than just another movie derived from a work by the world's greatest playwright. It is, whether or not the filmmakers are aware of the fact, a fighting document-a unique singular, debatable, and more often than not, temporary interpretation.

The notion of a unique and singular, fighting text (Brode 2000, p. 9) might also serve as an answer to the question: Why, given the availability of various copies of the original, do we get new versions? An answer I suggest here is that an original work's intention can be so meaningful to so many people that its message clamours for repetition and that repetition results in new interpretations. This, we might say, is the intellectual's version. The Hollywood version might well be: It made money the first time, why not do it again, but slightly differently? Hence film-making does not only seek to produce copies of an original print, it also attempts to re-use plots, characters, and even visual imagery, in the hope this will guarantee economic return. Not only do films do this within a genre, or a cultural context, but they are also capable of doing this across societies-requiring, perhaps, one more layer of translation for and by audiences. A film's intertextuality then is not limited to an individual director's vision, or to a particular social history, but is endlessly translatable by audiences.

3 Benjamin dismissed the possibility of defining the common characteristics of an audience 50 years before Ang (1991). 
Moreover, the translation of a foreign film—one of the subjects of this essay-occurs in different ways. The simplest, and most frequent, is simply the act of dubbing or sub-titling, although even these techniques might well require re-editing for length and/or censorship. When we see a 'foreign' film with subtitles, we are already seeing another version of the film, not merely just another copy. ${ }^{4}$ Again, Horton and McDougal (1998), among others, argue that there are two different ways of translating: The text that is a faithful, word-for-word translation, and the text which aims to accurately capture something of the original and render it comprehensible in another language. In film, subtitling is often assumed to be more or less close to the original dialogue, but anyone fluent in two languages is aware of how subtitles can get it very wrong, indeed.

Despite these problems, films are translated and appreciated across cultures. In this sense, the medium itself is transcultural, since despite cultural variations in both the narratives and visual styles that different societies favour, the technology is global and filmic techniques-while always evolving and changing - tend to be shared cross-culturally. To put it in another way, because film is a visual medium, it is possible sometimes to work out a plot without hearing the dialogue in film. We do this by deciphering the images; assuming that films are constructed according to a limited-and shared-grammar of sight. Therefore, another reason for films travelling cross-culturally is that they are seen to be fundamentally translatable as visual texts, and that human beings have come to share a way of seeing. This notion might well speak to translatability as being a quality that some texts have, pointing to a kinship of languages: Not an actual etymological kinship, but to a kinship of meaning, intent, and experience. As Lucien Taylor notes in his forward to MacDougall's (1998) Transcultural Cinema: '[T]he "shock" of film's transculturality, MacDougall suggests, is that through its particularity it evokes the universality of human experience-experience, in a word, that transcends cultural boundaries' (Taylor 1998, p. 19).

While it could be argued that what we understand by seeing is not easily shared cross-culturally, I agree with the notion that some texts are transcultural because they evoke the human condition and experience-both diachronically and synchronically. Additionally, some stories are so powerful that they become embedded in the folklore and/or high literature across many societies; thus becoming part of the knowledge that is taught to children, forming a template for understanding the world (Propp 1968). These are stories that get retold for they are seen to merit re-capitulating even in the same language. Such reiterations are both translations and re-assemblages, because they are attempting to work within new modalities of technology, or within historical moments, that allow for the original to be interpreted once again and, perhaps, in a different way. Hence Brode's use of the phrase 'temporary interpretation'. Moreover, because films are visual, they evoke another level of meaning and intent, a meta-level perhaps, which seduces us into thinking we completely understand others solely through the shared faculty of seeing, when actually it is similarities in the story that we recognise. ${ }^{5}$

Macbeth appears to be one of the narratives that is endlessly translatable. It is a gripping tale of a man tempted into hurrying up fate: Killing his King, in order to be king, after being told that this will happen in any event; followed by gory and supernatural consequences. It is a very 'visual' play as well, full of descriptive language about how the natural world reacts to this unnatural act. Many film-makers would think nothing of cutting such verbal description, making it visual and in a way tangible. However, few would get rid of all of Shakespeare's language-yet this is precisely what Akira Kurosawa did in Throne of Blood. Before analysing Kurosawa's version of Shakespeare's play, it is worth considering the 'original' tale itself.

4 For a discussion of the issues that Japanese subtitling raises, see (Nornes 1999).

Kurosawa also questioned the possibility that seeing is the same as knowing or understanding in Rashomon (1950). 


\section{2. 'Let Every Man Be Master of His Time' (Macbeth)}

Macbeth is often referred to as the Scottish play, due to the theatrical tradition that it is cursed and therefore must not be named by actors. Yet, it is an English play, written by an English writer in 1606, for a Scottish king, King James VI of Scotland, who became James I of England. Bradley (1991) tells us-as do other Shakespearean experts-that it is shorter than some of the author's other tragedies because the new King hated long plays. It is argued that the addition of witches to an actual historical event (the fall of Mac Bethad mac Findláich, c. 1005-1057, who became King of Scotland in 1040 and was dethroned in 1057), is because James I was interested in witchcraft, and had himself written a book on the subject. However, given the recent failure of the Gunpowder plot (1605), the topic of the play itself-the possible treachery of one's loyal vassals-seems rather close to the bone. A few scholars now question 1606 as the year in which the play was written, dating it back several decades, and see it as a commentary on the violence of the Tudor successions. ${ }^{6}$ This is still in contention, but whether the play was written in the seventeenth or the late sixteenth century, it clearly alludes to periods in which the succession to the throne had been marked by rebellions and uprisings. It can be read as a celebration of a new age-the almost peaceful succession of James—by relegating violent successions to a dark, primitive time and place.

More anomalous is the figure of Lady Macbeth, a barren and scheming woman who does not stop at murder to achieve her ends-an interesting woman to represent in a play written for a king who was heir to the childless and iron-willed Elizabeth I, who herself was half-sister to the infertile Mary Tudor. James I was also son and heir to Mary, Queen of Scots, who had been accused of plotting to murder James' own father. The depiction of a woman as potentially more evil and strong-willed than the men of the story is often taken to be an example of Shakespeare's—or just the era's—misogyny. The feminist scholar, Dusinberre (1996), has a difficult time arguing her way through to a sympathetic reading of the character (see also Rutter 1988). However, the linking of Lady Macbeth to barrenness is symbolically important, and would have resonated for seventeenth century audiences in London. As noted above, the Tudors had been haunted by this issue, whereas James I came to the throne with a large family already in place.

The resulting play is one that has long interested scholars and critics, and the role of the witches has been much discussed: Are they meant to represent the Fates or are they there only because the King was very interested in demonology? What did witchcraft mean to Tudors and Stuarts? Tudor and Stuart apprehensions about prophecies had much to do with their political implications-prophets and their prognostications were seen to be capable of inciting rebellion. ${ }^{7}$ The witches therefore signal a very real danger: The way in which some men were led to rebellion simply through the words and dreams of others.

The tension between whether the witches are meant to be Greek-like sibyls or political troublemakers is interesting in relation to the play's structure: Some scholars find it the most like a Greek tragedy of all Shakespeare's work, ${ }^{8}$ and see the role of the witches as a clue to this. In this regard, then, Macbeth would be like all the Greek tragic heroes who follow a particular path because it is ordained by the Fates and cannot be escaped, no matter how much they may try to resist. In contrast, scholars who contextualise the witches' role within Tudor and Stuart politics argue that since they do not represent the Fates, there is still the element of free will in Macbeth's story-it is all about giving into temptation. The latter is, obviously, a much more Christian reading of the play and possibly this is a more historically accurate interpretation than the former. Alternatively, Macbeth's Greek-like features might be just as intentional as the witches being there to flatter a king interested

\footnotetext{
Whalen (2003, pp. 54-70) sums up the arguments for an earlier date for the play.

See (Thomas 1971), see also MacFarlane (1970) for an anthropological analysis of witchcraft in this era.

Showerman (2011, p. 70) provides a good discussion of the scholarship on Shakespeare and Greek tragedy.
} 
in demonology: Shakespeare's works are full of intertextual references to other stories, plays, and theatrical traditions.

What makes this story so powerful? For Bradley (1991) it works precisely because it is short and pithy. The play's depiction of the path towards evil that is followed by a seemingly good man, a career soldier, a loyal vassal, is crucial—one that is often 'translated' into modern versions by setting the story amongst gangsters, leaving us with the modern implication that violent men come to violent ends. Yet Macbeth's mounting feelings of guilt over his crimes, and the growing insanity of his wife, seem modern also: Would the gritty warriors of old really have agonised so much over the killing they did on their way to power? No man in the play is free of the charge of killing others, yet there seems to be a fine line drawn between justified 'killing' and 'murder': The distinction between the two being, perhaps, new. ${ }^{9}$ His soliloquies offer us insight into the mind of a man tortured by bloodshed, and yet he is the product of a warring and feuding society in which bloodshed is the norm. This contradiction did not exist for the historical Macbeth, of course: It may have been a problem for inhabitants of Tudor and Stuart England and, possibly Europe, where constant warfare over the right to rule had long taken its toll. Macbeth is a particularly English play, however, in that it addresses the issues raised by a new religious culture: What happens when Catholic confession and subsequent absolution are no longer options for sinners? One obvious answer is that guilt becomes even more internalised and a very personal burden. Thus, the story presents audiences with an interesting tension between an old-fashioned method of succession and a 'modern' possibility of externalised guilt. ${ }^{10}$

If we follow this line of argument, Macbeth becomes a text that is deeply rooted in the history of the development of modern European self-consciousness and culpability. How, then, to translate this difficult tale to Japan-a society long assumed to be free of Christian notions of guilt, in which the emphasis is supposed to be on contextual shame, and notions of Shinto pollution (kegare). Such a typical Orientalist view has been disputed by anthropologists, such as Lebra (1983), and are also as challenged by Throne of Blood itself, through its framing as a Buddhist morality tale.

\section{3. 'Give Sorrow Words' (Macbeth)}

While it has been argued that Kurosawa's oeuvre can be read as an expression of his humanism (see especially Richie 1996), the Japanese came to brand Kurosawa as western-not just in influence, but in style and preference for the sorts of stories he turned into screenplays. Several of his films were based on the works of western writers: Gorky, Dostoyevsky, Ed McBain, Dashiell Hammett, as well as Shakespeare. ${ }^{11}$ Yet Kurosawa must be seen as a man of his era: Educated both within older Japanese values, and with a broad exposure to western arts, as were most educated Japanese from 1868 until the late 1920s. His stance was part of his early leftist political leanings, and coloured by his father's samurai values (Kurosawa 1982). His film-making style borrowed from the grammar of western films, ${ }^{12}$ but created a new visual grammar as well, which was in turn borrowed by western film-makers-a clear example of film's transcultural nature. Moreover, Kurosawa's moral questioning, popular with 1950s Japanese audiences, remained the same even while Japanese film viewers began to prefer less didactic and more upbeat movies in the 1960s. That is, much of Kurosawa's work can be read as social commentary on the horrors that war and a culture of violence inflict on society and its individuals. His films explore what the cost of that violence is; they beg the question of who should

9 See Martinez (2015) for a discussion of the 'modern' distinction between murder and justified killing.

10 This is an issue with which the comic novelist Pratchett (1989) wrestles in his version of Macbeth, Wyrd Sisters.

11 Galbraith's (2001) detailed filmography of the films Kurosawa produced, or for which he wrote screenplays, makes it clear that he dealt more often with Japanese themes and topics than he did with translations of western stories.

12 This covers a broad range, including Soviet (post-WWII) and European films. Kurosawa himself lists about 100 films that initially inspired him (Kurosawa 1982, pp. 773-74), which shows the diversity of his influences. 
shoulder responsibility and how; and depict how his protagonists morally respond to human brutality and social corruption. ${ }^{13}$

After most Japanese had begun to be optimistic about their country's future and economic prosperity in the 1970s, and while the popular gangster (yakuza) films of that era tended to celebrate Japan's warrior past and values, Kurosawa continued to explore these weightier themes (see Oshima 1992, pp. 26-35). His loss of popularity at home also could be read as pure box office politics: When his films started being too expensive to produce, and did not make money because they dwelt on less popular topics, Kurosawa lost the backing of the Japanese studio system. Throne of Blood, however, was made at the height of both his Japanese and western popularity-and yet was not a hit in either place, although it has since been labelled a classic in most western overviews of great film-making.

Throne of Blood is, as Kurosawa himself described, a version of Macbeth, written without any reference to Japanese translations of the play-he sat down with three collaborators (Shinobu Hashimoto, Ryūzō Kikushima, Hideo Oguni) and wrote the script. As with his other Shakespeare adaptation as medieval film, Ran (1985), it is set firmly in a feudal Japan where warring clans vie for the mastery of forts rather than kingdoms. Thus, Kurosawa found a transcultural commonality: ‘[A] parallel between medieval Scotland and medieval Japan which illuminated contemporary society; and further, a pattern which is valid in both historical and contemporary contexts' (Richie 1991).

In Throne of Blood we find that the three witches have become one web-spinning prophet (Niniwa Chieko), a Japanese figure that mirrors Greek ideas about the Fates, and Toshiro Mifune plays Washizu, the Macbeth figure. Additionally, to heighten the shared moral issues between the original and his version, Kurosawa choose to stylistically refer to Noh theatre, by having the main actors made up and, in the interior scenes, move as if they were on the Noh stage. ${ }^{14}$ Noh, a form of drama with origins in morality tales and largely shaped by Zen Buddhism, relies on the use of masks to depict characters' inner thoughts. Kurosawa's referencing of this theatrical form creates a connection to Shakespeare's very individual characters who invite us into their thoughts through soliloquies.

In Kurosawa's film, the closest we come to knowing Washizu's inner thoughts in spoken dialogue is during an early conversation with his wife, when she appears to know what he really wants, telling him that he is lying when he declares himself a loyal vassal. ${ }^{15}$ The use of mask-like maquillage and the elaborate costumes, which subtly change throughout the film, are thus important-in Noh they are mean to express internal states of mind. Just as Kurosawa transposes Shakespeare's descriptions of both the growing darkness in the castle and of the fear displayed by animals into unspoken but powerful images on the screen, he also chose to articulate the growing ambition and madness of his characters visually, through the changes in their appearance.

Despite this work possessing such an unusual (even for Japan) mise-en-scène, Throne of Blood has been praised as the 'only work ... that has ever completely succeeded in transforming a play of Shakespeare's into a film' (Blumenthal 1965, p. 190). In fact, it has also been called the most successful translation into a local set of conventions ever achieved with Shakespeare. Prince (1991, p. 143) argues: 'The images that he has created are not cinematic equivalents for the play. They go beyond the source to render the thematic and emotional world of Macbeth through indigenous aesthetic modes'.

Kurosawa himself, on the other hand, had a much more direct interpretation of his film. Donald Richie asked him what he hoped to achieve with his version of Macbeth, and Kurosawa said to him:

13 Desser (1992) discussion of narration as a moral act in Kurosawa's Ikiru (To Live, 1952), unravels these aspects of the director's work in a powerful manner.

14 Mifune as Washizu is made up as a typical Hieta (warrior) mask (see: https://nohmask21.com/eu/heita.html), while Isuzu as his wife Asaji, looks like any number of Noh female masks. I would argue that she resembles a Magojirō mask (see: http:/ / www.buddhamuseum.com/magojiro-noh-mask.html), a female character with a male name.

15 Niki's (1984, pp. 166-67) translation of this discussion from the original screenplay is more accurate than the Criterion Collection DVD edition of Throne of Blood. The subtitles read 'I know otherwise' when her husband claims that there is no treachery in his heart. Niki translates the screenplay with: 'You tell a lie'. In the film Asaji clearly says: 'Sora wa uso desu (that is a lie)'. We might accept all this as evidence that she knows her husband better than he himself does, and allow the varied subtitling. 
'I keep saying the same thing over and over again. Why-I ask-is it that human beings cannot get along with each other, why can't they live with each other with more good will? ... Throne of Blood, he added, was to show several of the reasons' (Richie 1996, p. 119). This broader intention requires us to consider the film as something more than a cultural re-interpretation. Rather than seeing the use of Noh as an attempt to translate the story into Japanese, we might ask if the use of Noh conventions signals Kurosawa's attempt to link the story firmly to a theatrical form that shared ethical concepts with the West. ${ }^{16}$

The Greek tragedies, which Macbeth is said to strongly resemble, were religious masked performances: Morality tales about the relationship between the gods, men, and fate. The earliest Noh performances were in Buddhist temples, a way of teaching basic Buddhist ideals to what was still, in early feudal Japan, a largely non-Buddhist population. Many descriptions of the film acknowledge the importance of Buddhist imagery in the story, seeing the sutra-like prologue and epilogue that frame the story as conveying this: '[T]he ruins show the fate of demonic men with treacherous desires. Life is the same now as in ancient times' (Niki 1984, pp. 109, 206). The song the witch Washizu encounters also could be described as Buddhist. She sings, ' ... what men do in this world, burning ourselves with the flames of five desires, bathing ourselves in the waters of five impurities, piling up our sins more and more ... ' (Niki 1984, p. 161). ${ }^{17}$

In Buddhism the five desires refer to the sensory experiences of the five senses; the five impurities are wilful desire, hateful anger, sloth, impatience, and obsessive doubt (see Hecker 2009, p. 122). Throughout the film, Washizu embodies all these impurities: He wants to succeed his leader and is impatient to be 'promoted' as the witch promises. He is angered by the thought that he might not be trusted, and increasingly doubts the men around him. Sloth might be seen to be one impurity he does not embody, but it could be argued that he is too indolent to battle against his wife's ill counsel.

Therefore, the impermanence of ambition, and the futility of violence, are endlessly cited as the moral of this tale. ${ }^{18}$ While this is not an incorrect reading of what Kurosawa has done with the story, it ties his aim much too firmly to a western interpretation of Japanese tradition. This interpretation ignores the fact that while in Buddhism the self is seen to ephemeral, it has attachments in life that lead to suffering and sin, and thus the self must pay for its iniquities in order to achieve enlightenment. The cobweb castle of the Japanese title points to the illusory nature of desire, but the horrific battle scenes and Washizu's death remind us that such illusions engender powerful experiences. Most importantly, the film's end clearly depicts the punishment of sin-it cannot be shrugged off.

By employing a style of acting that has been described as resembling that of ancient Greek theatre, Kurosawa highlights Macbeth's universality. It is a tale of ambition, murder, and subsequent guilt: Remorse, despair, madness, and nihilism are not just true within a European history, but also within a Japanese post-war setting. Without ever commenting on the western orientalist myth that described Japan as a 'shame not a guilt' culture, Kurosawa, in this film, makes a clear point: Individual Japanese, like individual westerners, struggle and have struggled with the morality of, responsibility, and guilt for their actions in all sorts of contexts from the medieval to the modern era. Throne of Blood shares with most of Kurosawa's work a strong main character who suffers and fights against the social expectations of others, although in this case he is not doing this in order to do the right thing. In this sense we can see how Kurosawa's film is a unique, and singular, version of the play, but I would also like to argue that it is a fighting document in another way: As an interpretation it adds a layer of understanding to

16 Of course, Greek tragedy might well be described as a historically 'Oriental' form of theatre.

17 Again, this is a more accurate, and in fact a less confusing translation than the current Criterion DVD subtitles for this section of the song: 'Humanity strives all its days to sear its own flesh in the flames of base desire, exposing itself to Fate's Five Calamities, heaping karma upon karma', leading to many an online discussion of what karma upon karma might mean. Other subtitled versions have entirely different words for this song, tending to convey the original Shakespearean sense rather than accurately translating the words and phrases.

18 Yoshimoto (2000) is also critical of this sort of simplistic interpretation in his massive book on how western critics did not understand Kurosawa's work, but he offers us no alternative explanations for the use of Buddhism. 
the story that 'rings true', and this is through his changes to the Lady Macbeth character, Asaji (Isuzu Yamada).

It could be argued that Asaji is the character most like her counterpart in the Shakespearean play. There is a tradition of demonic and supernaturally powerful women in Japan (Barrett 1989), where, as in Christian society, both Shinto and Buddhism saw women as the weaker sex, who were therefore more prone to sin and pollution than men. By keeping the characters of a witch and an evil wife in the film, Kurosawa points not just to a cultural similarity, but also to the idea that the witches must be understood as representing something very different than the modern western witch, who embodies the possibility of Faustian pacts. Rather, if we see the witches as being sibyls, making predictions that tempt men to evil acts as Shakespeare perhaps did, then both versions of the story present us with the problem of fate. In a Buddhist context our fate cannot be avoided, but it is how we live our lives that matters: Endurance for bad karma, and generosity when life goes well are all matters left to the individual. Macbeth/Washizu might well have done nothing if not encouraged by the women in their lives to act when no action was needed: They were going to be ruler, they needed only wait.

Thus, Kurosawa follows Shakespeare in asking a different question than the sort we normally encounter in Greek drama-not if our fate can be avoided, but what happens when we try to rush fate and twist it to our own ends? As in many of his films, Kurosawa also asks: Can a man used to action and violence ever change? Can he ever have, find, and live in peace? For those unfamiliar with Kurosawa's films even a quick look at his body of work reveals such characters: Hard men, perhaps even broken men, still trying to do the right thing. Most famous, of course, is the leader in the Seven Samurai (Shichinin no samurai, 1954), but there is also the doctor in Drunken Angel (Yoidori Tenshi, 1948), as well as the eponymous hero of Red Beard (Akahige, 1965), or Lord Ichimonji trying to 'retire' in Ran (1985). Even the morally ambiguous hero of Yōjimbō (1961) ends by bringing justice to an amoral landscape. Such characters, as Yoshimoto (2000, p. 328) has noted, frequently have an opponent who could be their doppelgänger-the man who embraces violence. Throne of Blood is an exploration of the moral consequences of such a choice.

The film asks, then, what is the moral toll of having been taught to kill in the name of the king/clan/emperor? Moreover, what sort of women inhabit the dark world of war and ambition? Both might be seen as post-Second World War questions. When Washizu says to Asaji 'I'd rather live peacefully, content with my lot', she replies: 'You won't have that peace', and goes on to describe the violent nature of their society: 'In this world, struggling for fame and distinction, parents kill their children and children kill their parents. This is a corrupt age when we must kill others to avoid being killed'19 (Niki 1984, p. 167). This is the society that has shaped Asaji: She looks and moves in accordance to Noh principles even more strictly than any other character save the witch and clearly symbolizing how she is a woman bound by strict social conventions (Richie 1996, p. 117).

Unlike Shakespeare who leaves us with the mystery ${ }^{20}$ of a barren woman asking to be 'unsexed' so that she might kill like a man-a woman who has known what having a child is like, but seems to have none in the story, and would sacrifice her future unborn children to her husband's dark ambition-Kurosawa makes Asaji a complete woman. She is ambitious not just for her husband, but for their unborn child, and would do anything to ensure the child's future as a ruler-Asaji schemes not just for herself, but for others. She is evil in her choice of means to achieve her ends, but she is a mother prepared to do anything for her child, who appears to have no place in the prophecy: It is Miki/Banquo's (Akira Kubo) children who are supposed to rule after Washizu. While her husband is

19 The filmed version compresses this speech.

20 Whether this would have been such a mystery to Shakespeare's contemporaries is another question: Stuart readers of Hollingshead's Chronicles of Scotland (Carroll 1999), upon which the play is also partially based, would have known that Lady Macbeth was older than the historical Macbeth and had a child by a previous marriage. After his death, there was an attempt to put Macbeth's stepson on the throne. 
tempted into hurrying fate, Asaji is fighting to defy it (all for their child), and the knowledge of her pregnancy also hardens Washizu's resolve-what he does is no longer for his own ambitions alone.

This difference between Lady Macbeth and Lady Asaji seems to serve as an answer to the question: Why does Lady Macbeth go mad? She seems to have no conscience, so how can she be struck down by guilt? Kurosawa gives us a believable answer: Asaji stakes all on what Washizu will do for their unborn child; when the child is born prematurely and dies, she cannot bear life. The death of her child can be seen as a punishment for her actions. This is, understandable, within a Buddhist context: Asaji pays for her sins, not only with the baby's death but with her own. In a medieval society, where a woman could be only wife and mother, there is nothing left for her. Asaji is more understandable, then, than Lady Macbeth appears to be-her end makes clear sense without the need of tortured interpretations which struggle to come to terms with such evil in a woman. Asaji is in a sense every woman: Frightening in her ambitions for her child.

The existence of this baby gives Kurosawa's version of the story an added, and in this case also a Buddhist, dimension. With its death, the couple leave no heirs, no one to pray for them in their afterlife, no one to make merit for their sins, thus ensuring that they will be reincarnated or finally reach Nirvana. The death of the baby condemns them to hell (for Buddhism has hells upon hells), or a wandering afterlife as hungry ghosts. This is hinted at by the film's opening scene in which the mists part to reveal a stupa (used in Japan as grave-markers), marking not Washizu's grave, but just noting that Kumonosu castle once stood there-the couple are forgotten. Yet as Japanese as this interpretation is, it continues to resonate with something of the Protestantism of Shakespeare's age-where the burden of sin was inescapable.

\section{Towards a Conclusion: 'Life Is ... a Tale' (Macbeth)}

To conclude that Shakespeare transcends time and culture would be to end with a cliché that tells us nothing new. Instead we should ask: What do we learn by looking at Kurosawa's deterritorialization and re-assemblage of Shakespeare's play? Kurosawa was not the first director to understand that some of Shakespeare's language, so descriptive, could work best as the visual element in a film. His version contrasts scenes of mist with sharply-focused, bloody battles, bright sunlight with dark interiors. While there is no discussion of 'in thunder, lightning, or in rain', ${ }^{21}$ Wasaji and Miki ride through all three before meeting the witch; and night seems to dwell within the castle, turning Asaji, dressed in a luminous white kimono, into a ghost-like figure even before her suicide. In short, there is no need to set a camera up and have people describe their surroundings, when that can be done so much more easily on film than on stage.

As part of his auterial vision, Kurosawa might be said to have pushed his version beyond the bounds generally expected; by dropping the monologues, the expression of the characters' inner emotions, he pushed at the cultural and historical boundaries of what Shakespeare had tried to portray to comment not just on medieval Japan's culture of violence, but also on that of the Japanese Empire (1868-1947). The body of Kurosawa's post-war work speaks to his interest in the problems of corruption, violent action, and the question of how to act morally. This makes even more interesting his addition of Lady Macbeth's pregnancy - as for the Japanese, as with all Buddhists, descendants are important: Without them there is no one to pray for their dead souls to rest in peace, or have a good rebirth. Yet, for the Tudors and Stuarts, being barren was also an issue, and this was a topic that had haunted the English monarchy for decades.

Deleuze and Guattari (1986) argue that an author's re-assemblage allows for the possibility of a text to become both political and something new. The 'new' can result from recasting the story in a new context, as well as from the interpretative relationship that the audience has with the medium.

21 See Nishimura's (1990) book for an insightful and technically detailed discussion of Kurosawa's use of both sound and light in his films. 
For the political message we need to consider the auteur's vision as part of this process. In Throne of Blood, almost perversely through the use of Noh conventions, Kurosawa wanted to invoke not just the power of theatre as ritual, but to make the audience think about limitations: The closed and artificial conventions of a constantly warring society. A man bred to war is shaped by his past, to try and break the mould, as Kurosawa also shows in Ran, is nearly impossible in the 'theatre of violence' that was both samurai society and the Japanese Empire. This is yet another example of his critical view of the modern Japanese reverence for the 'way of the samurai' (bushido), and the popular depictions of the yakuza as a contemporary embodiment of this 'way'. While seen as a great master of samurai, or period, drama (jidai gekei), serious analysis of his films in this genre reveal his stance. The husband in Rashomon is a coward; the bandits in Seven Samurai were once samurai; the yakuza in Yojimbo are all grotesque; Sanjuro (1962) is about a sustained effort at resolving problems peacefully; and Kagemusha is about the futility of war (1980).

Thus, Kurosawa's version of Macbeth is both true to Shakespeare, who was reflecting on the violence that had framed royal succession over centuries in England and Scotland and, yet, it is something else as well—unlike Shakespeare, as Richie (1996) notes, there is no possibility of a happy ending, there is no Macduff to come and set things right. As Goodwin (1994) points out, the shots of the destroyed castle, framing the film at the beginning and end, and the use of wide empty spaces tell us something about the insignificance and danger, in Buddhist terms, of ambition. In his version, Kurosawa seems to well illustrate what Michael Billington (2002, p. 4) noted of Calixto Bieito's staging of the play: 'Shakespeare in translation offers both loss and liberation: What you get is an analogue to the original that allows the director to search out the play's metaphorical meaning'.

Despite the fact that Throne of Blood gave raise to various critical reactions (from being called an 'awful' version of Shakespeare to 'the best'), and apparently offers opportunities for western over-interpretation, orientalising the significance of the film so that it would appear to be beyond western comprehension, essentially Kurosawa's version of Macbeth is about how Shakespeare should look and feel, not just about how he should 'sound'. Kurosawa understood that in a film version of Shakespeare, the language of the camera becomes another possible mode of interpretation-another mode of understanding, and another way of exploring the consequences of violent action. His use of Noh is a clear clue to the importance of the visual for understanding his meaning, but it is almost too personal an interpretation: It remains difficult for many viewers, including Japanese audiences. Yet, the film's powerful images never fail to impress and tend to remain embedded in viewers' minds: Washizu pierced by endless arrows is now a famous transcultural image, recreated in myriad ways in other movies. Kurosawa's version of Macbeth, then, is not just about sound and fury signifying nothing, but about sight and sound and fury, signifying something new.

Funding: This research received no external funding.

Acknowledgments: In organizing the research for this paper, I had the help of Helen Hacker, who sent me a first reading list on Shakespeare on film, which I have by no means exhausted. For a discussion that helped focus my ideas, I am grateful to the SOAS Ideologies and Genre Workshop conference in 2002. John Lobreglio quickly responded to some questions relating to Buddhism; while my colleague Kit Davis helped by asking a very simple but important question; and David Gellner read and critiqued the first draft. All errors in the paper, however, are my own.

Conflicts of Interest: The author declares no conflict of interest.

\section{References}

Ang, Ien. 1991. Desperately Seeking the Audience. London: Routledge.

Barrett, Gregory. 1989. Archetypes in Japanese Film. London: Associated University Presses.

Benjamin, Walter. 1973. On the Work of Art in the Age of Mechanical Reproduction. In Illuminations. Edited by

Hannah Arendt. Translated by Harry Zohn. London: Fontana, pp. 211-243.

Billington, Michael. 2002. Macbeth in Barcelona. The Guardian, February 30, 4.

Blumenthal, John. 1965. Macbeth into Throne of Blood. Sight and Sound 34: 191-95. 
Bradley, Andrew Cecil. 1991. Shakespearean Tragedy. London: Penguin Books.

Brode, Douglas. 2000. Shakespeare in the Movies. Oxford: OUP.

Carroll, William C. 1999. 'Introduction' to his edited William Shakespeare. London: MacMillan Press Ltd.

Deleuze, Gilles, and Félix Guattari. 1986. Kafka, Toward a Minor Literature. Translated by Dana Polan. Minneapolis: University of Minnesota Press.

Desser, David. 1992. Ikiru: Narration as a Moral Act. In Reframing Japanese Cinema. Edited by Arthur Nolletti Jr. and David Desser. Bloomington: Indiana University Press, pp. 56-58.

Dusinberre, Juliet. 1996. Shakespeare and the Nature of Women, 2nd ed. Houndmills, Basingstoke and Hampshire: MacMillan Press Ltd.

Galbraith, Stuart, IV. 2001. The Emperor and the Wolf. New York and London: Faber and Faber.

Goodwin, James. 1994. Akira Kurosawa and Intertextual Cinema. Baltimore: The John Hopkins University Press.

Hecker, Hellmuth. 2009. Similes of the Buddha. Kandy: Buddhist Publication Society.

Horton, Andrew, and Stuart Y. McDougal. 1998. Introduction. In Play it Again Sam. Berkeley: University of California Press, pp. 1-14.

Kurosawa, Akira. 1982. Something Like an Autobiography. Translated by Audie Bock. New York: Vintage Books.

Lebra, Takie Sugiyama. 1983. Shame and Guilt: A Pyschocultural view of the Japanese Self. Ethos 11: 192-209. [CrossRef]

MacDougall, David. 1998. Transcultural Cinema. Edited by Lucien Taylor. Princeton: Princeton University Press. MacFarlane, Alan. 1970. Witchcraft in Tudor and Stuart England. London: Routledge.

Martinez, Dolores P. 2015. Kurosawa's Noir Quartet. In East Asian Film Noir. Edited by Chi-Yun Shin and Mark Gallagher. London: I.B. Tauris \& Co. Ltd.

Niki, Hisae. 1984. Kumonosujō, Throne of Blood. In Shakespeare in Japanese Culture. Tokyo: Kenseisha, pp. 108-35.

Nishimura, Yūichirō. 1990. Kurosawa Akira: Oto to Eizō [Akira Kurosawa, Sound and Light]. Tōkyō: Rippū Shobō.

Nornes, Abe Markus. 1999. For an Abusive Subtitling. Film Quarterly 53: 17-34. [CrossRef]

Oshima, Nagisa. 1992. Cinema, Censorship and the State: The Writings of Nagisa Oshima, 1956-1976. Edited by Annette Michelson. Translated by Dawn Lawson. Cambridge: MIT Press.

Pratchett, Terry. 1989. Wyrd Sisters. London: Corgi Books.

Prince, Stephen. 1991. The Warrior's Camera, the Cinema of Akira Kurosawa. Princeton: Princeton University Press.

Propp, Vladimir. 1968. Morphology of the Folktale, 2nd rev. ed. Translated by Laurent Scott. Austin: University of Texas Press.

Richie, Donald. 1991. 'The Throne of Blood', Comments for the Criterion Collection. Available online: https: / / www.criterion.com/current/posts/938-throne-of-blood (accessed on 16 May 2018).

Richie, Donald. 1996. The Films of Akira Kurosawa, 3rd ed. With additional material by Joan Mellen. Berkeley: University of California Press.

Rothwell, Kenneth S. 1999. A History of Shakespeare on Screen. Cambridge: CUP.

Rutter, Carol. 1988. Clamorous Voices, Shakespeare's Women Today, 5th ed. London: The Women's Press Ltd.

Showerman, Earl. 2011. Shakespeare's Greater Greek. Brief Chronicles 3: 37-70. Available online: http:// shakespeareoxfordfellowship.org/wp-content/uploads/Showerman.Macbeth.Oresteia.pdf (accessed on 16 May 2018).

Taussig, Michael. 1993. Mimesis and Alterity. New York and London: Routledge.

Taylor, Lucien. 1998. Introduction. In Transcultural Cinema. Written by David MacDougall. Princeton: Princeton University Press, pp. 3-21.

Thomas, Keith. 1971. Religion and the Decline of Magic. London: Penguin Books, Ltd.

Truffaut, Francois. 1954. Une Certaine Tendance du Cinema Français. Cahiers du Cinéma 31: 15-28.

Whalen, Richard F. 2003. Shakespeare in Scotland. The Oxfordian 6: 54-70. Available online: https:// shakespeareoxfordfellowship.org/wp-content/uploads/Oxfordian2003_Whalen-Macbeth.pdf (accessed on 16 May 2018).

Yoshimoto, Mitsuhiro. 2000. Kurosawa, Film Studies and Japanese Cinema. Durham: Duke University Press.

(C) 2018 by the author. Licensee MDPI, Basel, Switzerland. This article is an open access article distributed under the terms and conditions of the Creative Commons Attribution (CC BY) license (http:/ / creativecommons.org/licenses/by/4.0/). 

Article

\title{
The Aesthetics of Flow and Cut in the Way of Film: Towards Transnational Transfers of East Asian Concepts to Western Film Theory
}

\author{
Simon Frisch \\ Faculty of Media, Bauhaus-Universität Weimar, 99423 Weimar, Germany; simon.frisch@uni-weimar.de \\ Received: 4 March 2019; Accepted: 28 August 2019; Published: 16 September 2019
}

\begin{abstract}
The general concepts in theorising the aesthetics of film are still rooted in occidental traditions. Thus, thinking about film is dominated by Western terms and aesthetic paradigms-such as "pieces of work", the representation of reality or regarding the arts as an act of communication. From such an angle, it is difficult to describe different characteristics of the cinematic image, for example, its ephemeral character. In contrast to occidental thinking, the cultural traditions of East Asia are based on the concept of the way (do or dao), which allow for the description of aesthetics of transitions and transformations. Inspired by the concept of kire-tsuzuki, as developed by the Japanese-German philosopher Ryōsuke Ōhashi, I shall, in this paper, describe some alternative ways of understanding appearance and occurrence in relation to the cinematic picture.
\end{abstract}

Keywords: cinematic picture; film aesthetics; theory of beauty; ikebana; kire; geidō; film philosophy; Japanese aesthetics; transcultural thinking

\section{Introduction: Ways of Cutting the Flow of Tea}

The cultures of tea in China, Japan and European countries differ, in part, in their methods of steeping. In Chinese tea culture, one teapot is usually steeped up to six times or more, and the duration of the infusion is quite flexible. In Japan, one pot of tea is usually steeped not more than three times, and the infusion times are quite exact: the first infusion is sixty seconds, the second is fifty to twenty seconds, and the third infusion takes three minutes. In traditional Western tea cultures, such as in England or northern Germany, one pot of tea is steeped only one time with an exact point of "cutting off" the process of infusion. Chinese tea practice seems to be interested in participating in the process of the evolution or, rather, in following the flow of the tea as a whole. Tea culture in Japan seems to focus on singling out particular, precise moments from the process of infusion, each possessing their own particular taste. In Western tea culture, the tea is steeped in order to get the unique and genuine taste of the tea. Not only are the steeping methods different, each culture includes its own imagination of tea. However, each taste of tea is real, and there is no taste of tea beyond infusion practice.

By contrasting tea cultures in such a way (admittedly simplified and schematic), we are touching on fundamental aesthetic questions. These questions also concern fundamental aspects of thinking about film: in particular, the moving image, the course and transformation of the image, the practice and the effects of cadrage and framing, as well as cutting and editing, and the aesthetics of continuity and discontinuity. The examples of Asian tea cultures open up horizons for examining aesthetic problems of film beyond those perspectives that we typically consider universal-for example, the basic difference between reality and imagination but also concepts of representation, reflection, mimesis and illusion that often figure in the theory of the cinematic image. 
In this paper, I would like to propose a model for rethinking the main concepts and criteria of film theory and film philosophy, which are still dominated worldwide by occidental traditions of thinking-most basically by Western terms of aesthetics. ${ }^{1}$

\section{Kire (Cut): A Different View on the Cinematic Image}

In the history of modernity, there have been numerous transfers of concepts from occidental to oriental culture, which does not seem to be the case when one considers a movement in the opposite direction: theoretical concepts and terms from oriental culture seem to have hardly ever been transferred to the Occident. One could call this a form of Eurocentrism in the Asian world in the 20th century, primarily in Japan in the Meiji period. However, even if 20th-century European thinking remains occidental-based, modern European artistic culture is shaped and strongly marked by non-European influences, above all from Japan (Japonism) — e.g., Impressionism, Art Nouveau, Brecht, Cage, modern architecture. Looking closer, one can find countless inspirations and influences of Japanese (and also Chinese) culture in modern Western thinking-e.g., Heidegger, Barthes, Derrida. There seems to be a gap between the 'practice' of theory and the general self-perception and the discourse about the evolution and the origins of 20th-century European philosophy (May 1996; Parkes 1987).

Although cinema was invented in the Occident (by the Lumière brothers in France, Edison in the United States, Skladanowsky in Germany, etc.) and introduced to most countries by the Lumière brothers, its aesthetic articulation, constitution and form are not necessarily rooted in occidental traditions. The most important characteristics of film-its transitory and ephemeral character and the movement of the cinematic image-are not compatible with the concept of the image in traditional occidental aesthetic theory. Furthermore, the idea of the cinematic image in terms of representation or realism originates from concepts of the image in Renaissance painting and not so much from the photographic technique itself.

Against this background, it is interesting to refer to concepts of the image beyond occidental-based theories. In fact, there already exist quite prominent tendencies to reconceptualise traditions of Western aesthetics. In 1970, Barthes (1970) proposed from the angle of Japanese aesthetics a theory of signs beyond occidental paradigms. The idea that images are creations and concrete beings, and not representations, resonates with Lev Manovich's and William J. Mitchell's understanding that digital images are the effects of a kino-brush rather than a kino-eye. In recent times, Western digital film theory has moved further away from the description of traditional occidental film theory (Manovich 1995, 1996; Mitchell 1992). However, as far as I see, it is not the digital technique that is changing the character of images. The technique has only raised awareness of certain aspects in the aesthetic of images that already existed. Even if they were not important in Western culture, they may have already had importance in non-occidental cultures.

I would like to propose perspectives towards a different aesthetic of film from the angle of a concept presented by the Japanese-German philosopher Ryōsuke Ōhashi in his book Kire. Das 'Schöne' in Japan ['Beauty' in Japan] (Ōhashi 1994, 2014). ${ }^{2}$ Ōhashi considers kire, a fundamental aesthetic principle in the Japanese concept of beauty. Although he concentrates on Japanese culture, Ōhashi also suggests that the concept of kire could be expanded to other contexts. Ōhashi's book could be taken as an inspiration in order to analyse questions of film aesthetics. Yet, surprisingly, he does not mention film in relation to this concept, which is what I will examine in this paper: I will adopt the concept of kire in order to discuss particular aspects of the cinematic image and hence introduce a non-occidental aesthetic concept in thinking about film.

1 From the 1990s on, however, there have been English translations of Chinese and Japanese film theories and film critics: Semsel et al. (1990) and Semsel et al. (1993). About Japanese film critics, see: Iwamoto (1987); Gerow (2010a, 2010b) and Satō (2010). See also Fan (2015).

2 The book was published first in 1994; there is a revised edition from 2014 that contains new texts (Ōhashi 1994, 2014). 


\section{The Concept of Kire (Cut)}

The Japanese word kire as a verb means "to cut" or "to separate", but also "to free". As a noun kire means "cutting" or a "cut", a "piece cut off", a "slice", a "section" or a "segment". However, kire can also mean "dissolving". As an adjective, kire can today be used in the sense of "racy", "sleek", "dashing" or "edged" to characterise, for example, a car, a wine or a person. ${ }^{3}$

Ōhashi describes kire generally as an artistic practice that tends to liberate dependencies, relations and contexts (Ōhashi 1994, p. 59). This act of liberating things from their natural ambience is considered to be a process of enlivenment or vivification. A specific way of cutting gives birth to things in a new way of being, which is considered essential. The concept of kire literally implies an act or process of "bringing something to life", which can only be roughly captured by the translations used here.

Kire marks an important difference from traditional Western aesthetics, the key concepts of which are based on imitation and the representation of life. To understand that difference, it is important to be aware of a general trait in Japanese aesthetics: in the names of traditional arts in Japan (geidō), such as chadō, kadō, jūdō, etc., the suffix -dō indicates a relation to Chinese Daoism. In its aesthetic context, the $d \bar{o}$ or dao, what we can translate as flow or the way, is different from the Western concept of the arts, which is concentrated on pieces of work (Hammitzsch 1957; Hashimoto 1998; Imai 2004; Ōhashi 1998; Seubold 1993). Japanese art and aesthetics are more focused on movements, processes or certain gestures than on pieces of work. In geido, there are no gestures of communication or expression such as those present in occidental culture. Furthermore, geidō has not to do with lifelike effects. The aspect of vivification in geidō must not be understood as an "as if ... "; rather, it is considered a real instance of vivification—a new and different kind of life and reality. The contrast between "real" and "aesthetic" or "real" and "artificial" is not crucial. Pygmalion's Galatea is the opposite of geidō.

Ōhashi considers the poetics of geidō as particular aesthetics of the cut (kire). However, it must be considered that kire does not only mean "cut" in a literal sense of slicing material things. As an example of the way the aesthetics of kire works, Ōhashi examines the 'flow of walking' in Nō theatre:

On the stage, while walking, the actor slides forward inaudibly and slowly. This slow pacing deprives the usual walking, which corresponds to the flow of time, of its reality. However, at a closer look one can recognise in this way of pacing an extremely stylised way of human's walk. While lifting the toes of his foot, the actor slides his whole foot forward. Every step - both that of the right foot and the left foot-is completed by the actor by dropping his toes, and hence every step is cut. With this kire (cut), however, the next step has already begun and thus the pacing forward continues. What we can note here is a continuity which contains a kire, a cut, since one foot cannot continue until the other has made its cut . (Ōhashi 1994, p. 14; my translation)

In pointing out the importance of the combination of the cut and the continuation in the step, Ōhashi establishes actually an aesthetic of continuity as the essence of kire. The cut is an end and a beginning. This combination he calls kire-tsuzuki ("cut-continuity"). The walking forward on a Nō stage seems to be withdrawn into itself so that it is not connected with any context: there is no target to reach by walking, no path to walk on. Instead, the walking is endowed with an inner dimension of time and space. In the practice of $N \bar{o}$, by withdrawing the pace into the concrete gesture, the essence of walking is produced—or one can also say: the beauty of walking. One can say that in the 'way of the arts' (geidō), the execution of gestures simultaneously withdraws them into itself. This means that

3 I thank the participants of the conference in Frankfurt in 2013 and of a workshop in 2017 at Keio University, Tokyo, especially Kentaro Kawashima, for the explanations of the meanings of kire in contemporary life.

4 When revising this paper, I was referred to Terada Torahiko's film theory, which was grounded in scientific universalism and, as such, poses a challenge to the occidental aesthetic concept of thinking about film. With Terada, one could explain how the effect of vivification is achieved. It is surprising that Ōhashi does not create a reference to Terada in his concept of kire. This is a subject for further research. 
each gesture that is executed, at the same, is incorporated into the person who is acting (e.g. walking, painting, writing, moving, etc.).

\section{Ikebana: The Flower and the Blossom of Beauty}

The core of ikebana is the cutting of the flower and its arrangement among other flowers. Ikebana is often misunderstood as an art that draws on resources from natural life. However, it is not about imitating or representing natural life. The word ikebana literally means "to enliven the flower". The cut flower thus is not dead. Ōhashi describes the result of this process as "the truth of the living flower", which entails cutting away the natural life of the flower (Ōhashi 1994, p. 69, my translation). Ikebana must be understood as a transformation of the natural flower from the meadow to another nature, which is real and natural but different from the life of the flower in the meadow. The cut produces an aesthetic existence for the flower. That aspect can also be applied to the take in a film: a take can be described as a section taken, or cut, from life. This cut results in a transformation from real life into cinematic life. What we can learn here from ikebana is to give up the idea that there is only one sphere of liveliness and reality. Similar to the liveliness of the cut flower in ikebana, we can develop a concept of the cinematic shot as producing a living image. We will no longer think in terms of lifelikeness or similarity but, rather, regard the picture itself as the origin of its own cinematic liveliness.

It is interesting, in this context, that one of the most important contemporary ikebana artists in Japan, Toshirō Kawase, wanted to become a filmmaker in his early years. ${ }^{5}$ While studying in Paris, he discovered the films of Tarkovsky and began to understand that there was a relation between film and ikebana. Moreover, what he was interested in doing with film bore a strong resemblance to the aesthetics of ikebana. He thus went back to Japan to become a grand master of the practice. Considering Kawase's foundation in film can support our rethinking of the aesthetics of the shot and the cinematic image: the cinematic take is—similar to the flower-cut out from nature. The cinematic liveliness results firstly and directly from the shot. It does not result from 'lifelikeness'. The cuts and the cut pieces (the takes) are working in a specific sense: the living-not lifelike-images act similar to the flowers in ikebana, which establish a new reality within and without the arrangement. The interdependence of all elements and cuts creates a particular reality. In other words, the cut does not destroy the flower's existence, on the contrary. The flower gains a new temporality and a new spatiality. Thus, ikebana can be understood as an arrangement of time and space, and different scales and modes of presence, organised by kire. $^{6}$

The new existence of the flower in ikebana is often considered its essence (Ōhashi also writes in this sense). However, this term is misleading. From the angle of ikebana itself, the cut is an introduction or fabrication of something that was not there before. The flower appears in a realm of beauty. The beauty never existed before, and yet, the flower appears to have always had this beauty. It is its own and proper beauty, and a beauty at the same time introduced and revealed by the cut. The cut causes the flower to appear and at the same time disappear. This is a process that never stops: the cut flower causes an eternal flowing presence and absence, emptiness and opulence, of on and off. ${ }^{7}$ There is a fundamental concept and a cosmic dimension of beauty in kire. The beauty of the flower in ikebana is not defined by external criteria; rather, it is informed by operations such as cutting continuity (kire-tsuzuki) and shifting (zure) in the dimensions of time and space. Shifting-zure in Japanese-is a category used by Okakura in his Book of Tea to characterise a specific aspect in Japanese aesthetics, which he describes with terms such as imperfect or incomplete. ${ }^{8}$ However, as he wrote his book for

Kawase (2000): [Toshirō Kawase about his biography].

6 A Japanese colleague of mine, Kayo Adachi-Rabe, said her ikebana master told her that she should not so much think of arranging the flowers but of arranging time and space by arranging flowers.

7 The specific movement of flow in the aesthetics of East Asian cultures is related to the importance of the flow of chi (or ki).

8 Kayo Adachi-Rabe refers to different categories of incompleteness presented in Okakura's Book of Tea (Adachi-Rabe 2016, p. 53; Okakura 2008, p. 40). 
Western readers, we must consider that this might be a description from an angle of Western aesthetical criteria. In order to understand the proper aesthetics of operations such as shifting (zure) and cutting continuity (kire-tsuzuki) we must try to understand these aesthetics as perfect and complete.

Similar to the practice of ikebana, film as an entity has its living existence in the arising of a characteristic beauty, for which we do not have proper criteria to judge or measure. In traditional Japanese writings about the arts, we do not often read about beauty but, rather, the blossom, which is essential in Japanese aesthetics. ${ }^{9}$

\section{Hokusai's Frog, Hiroshige's Cat, Craftsmanship and the Alienation of Violence}

Ōhashi provides another example: an illustration from Hokusai of a fairy tale by the author Bakin Kyokutei (1767-1848). The woodcut print shows the witch Kumagimi cutting an embryo out of Niigaki's belly. The scene in Hokusai's picture is characterised by extremely cruel and brutal violent action, but this violence is also combined with the great diligence of the artist's craftsmanship. This is a contrast that could be considered an instance of the aesthetics of kire: the contrast is a cut, which at once outlines the cruelty and the delicacy of the artwork. The cut, in the sense of kire, lifts the violence of the scene into alienation. The woodblock print is made with visible strokes, which, however, are stylised and abstract in a certain fashion. We can remember here the incompleteness in Okakura's Book of tea. Thus, the work of creation is not finished with the job of the artist. There is still a process of creation at work in the artwork itself: from the strokes of the cut, the scene is emerging.

Further, Ōhashi points out a little frog sitting in the left lower corner of the image, looking towards what is happening in the picture. Ōhashi writes: "The small frog who is separated from the scene that occurs in front of him changes the sense and the meaning of the scene" (Ōhashi 1994, p. 123). The frog has no value for the story nor for the formal composition of the image. As Ōhashi explains, the frog's meaning arises from its absolute meaninglessness (Ōhashi 1994), because, from the perspective of a frog, what happens in the scene is meaningless. From a frog's point of view, there are no such things as violence or cruelty. He does not see the scene in terms of drama, pain or guilt. From the frog's viewpoint, the scene arises on a new horizon, losing its emotions, its meanings and its moral implications. The frog, almost invisible at the edge, is a key figure of the picture, because it absorbs the scene and reveals the aesthetic mode in which the picture operates. Thus, the picture gains its form, its materials and its details as an artwork.

However, the frog could also be a cat. In a woodcut by Hiroshige from the series One Hundred Views of Edo titled "Asakusa Ricefields and Torinomachi Festival" (1861), there is a cat sitting on a windowsill in the foreground of the image. It is watching, while almost sleeping, the parade of the festival in the background of the picture, which is so small that it is almost not visible. From the angle of the cat, the festival is only part of the landscape. There is also a cat in Paul Verhoeven's film Elle (2016) watching the rape of the protagonist (Isabelle Huppert), and its view transfers the violence of the rape into a realm of indifference. The frog's and the cat's viewpoints produce a cut in the scene: kire. The presence of the frog or the cat (or anything else that introduces a kind of alienation) creates an endless number of scenes, as suddenly there are cuts everywhere, even between us (the spectators), the picture and its moral implications. All things become visible from multiple angles. What before was assembled into a scene in the narration of violence is split into countless portions and pieces, opening various points of view from which arise endless combinations. Thus, there is an endless process working in the picture by which it is permanently creating itself.

It would be misleading, however, to deduce that violence and cruelty are dissolved by kire. The more they are liberated from the narration, the more they emerge in a different realm of aesthetics, which might be disturbing because of moral reservations. One might also remember here the first scene of murder of two women in Dario Argento's film Suspiria (1977). The colours, the striking set design of

9 See e.g., the writings of Zeami and the studies on Zeami's aesthetics, in which the blossom is a central term (Zeami 2008). 
Art Nouveau architecture, the emptiness and loneliness of the night, the artificial and stereotypical innocence of the two young women and the music all combine with a high level of cruelty and violence in this scene, which ends with a shot of the two dead women. Their bodies are composed alongside elements of broken glass and steel, the ornaments on the wall and floor and the deep red of blood. It is an image of disturbing beauty - we reckon with the cruelty of the murder, but the diligent crafting of the scene cuts the picture from moral judgements just as in Hokusai's woodcut of the witch Kumagimi. It would be misleading to describe this aesthetic in terms of the delightful horror-rather, we gain more access to the aesthetic of these images in terms of kire by understanding the operations of cuts.

The aesthetics of kire consist of dissolving fixed relations between elements, and between elements and sentiments, so that new horizons arise, which recombine elements, sentiments and affects in multiple possibilities. We can move our gaze and our mind from the diligence of the artwork to the story in the presented scene within its moral framework, to our sentiments and emotions and back again to the drawing, to the material of the paper and to the blackness of the ink. Thus, we draw a powerful lesson from Hokusai's frog: the dimensions of things are always changing, always inconsistent. We can see a link here to Zen scepticism, but there is no such thing as agnosticism in the aesthetics of kire. Rather, it induces a form of vivid awareness, of becoming conscious of an endless movement of vanishing and arising, and the acceptance of unity of contradictions beyond or above causal logic. For Western logic, this combination of radical relativism with definite truth is a paradox. From the angle of occidental concepts of the image, the cinematic image is thus a paradox: its existence is fundamentally based on a movement, which unites arising and vanishing at the same time, its persistence is related to processuality and permanent change (even if there is not a motif in motion). We gain a new concept of the image as a creative process: it is an image in the state of producing itself in the process of appearing, even as it is produced before in the film production process. Kire then could describe the working process in the images themselves.

\section{Movement, Time and Space in the Cinematic Picture}

At the beginning of the film Rashomon, when the woodcutter tells his story, the aesthetic structure of the film becomes obvious. The woodcutter can be viewed as Hokusai's frog. Similar to the frog pointed out by Ōhashi in Hokusai's picture, the woodcutter in Rashomon is no protagonist, but similar to the frog, he is a central-albeit not the key-figure of the picture. The movie has a void at its centre. Again, similar to Zen, the film draws its cosmos around emptiness (the nothing). In a conversation about this movie, film scholar Kayo Adachi-Rabe proposed that the whole film could be seen as a dynamic ikebana. Very characteristic in this respect is the openness of the film into a quiet room in front of the screen in the scenes in front of the court, which is never to be heard. The movement, the time and the space in Rashomon are transferred to a cinematic process.

The comparison of ikebana and film leads us to the concept of cinematic time and cinematic space. However, there is not first the picture and second the movement. The film's movement, time and space must be sought within or better as the existence of the picture. Thus, we can say that the cinematic image is an image that contains movement and space in itself, and vice versa, it is the content of these movements and spaces. If we extend this reciprocity a little further, we ultimately renounce the idea that images contain or show something. What we usually refer to as what images contain or show is rather the form in which the images exist. Cinematic movement can move through time or through space. Several films are playing with different dimensions of spatiality and of temporality of cinematic movement. A classic example is the opening sequence of Alain Resnais' film Last Year at Marienbad (1961). The camera moves through the rooms of a castle, reaching a room with a group of people who are standing and sitting around without moving. The camera continues moving between them. We get 
the impression of moving through the impossible space of a photograph. ${ }^{10}$ The picture is frozen and moving at the same time. The story of the murder in Rashomon is similar: it is frozen insofar as it could be regarded again and again from different angles, and it is moving because it looks different from each angle.

What we can glean from these observations is that there exist specific cinematic forces, or rather energies, which are able to give life to figures, things and places. The form of their existence depends on particular cinematic articulations. For example, the sequence of different camera angles in the sequence showing the process of walking through the forest at the beginning of Rashomon recalls the little frog of Hokusai, such as when we see the woodcutter from a great distance or when he is shown from very high or low positions. It is as if several 'Hokusai frogs' are sitting around and looking at the scene, offering different angles and perspectives to it. As a result, beside the walking forward, one cannot identify a route or any spatial or chronological order. There is only the walking, and we are provided with no clues as to who the woodcutter is, where he comes from or where he is going.

The characteristic operating mode of $N \bar{o}$ is to conceal the expression of the human body and to dissolve the natural hierarchies between human beings and things (costumes, masks, stage elements, props, etc.) in order to $c u t$ them all together in the realm of vivification of the art of Nō. This could be considered the characteristic of beauty in this performative tradition. In comparison, movement and performance in film are first and foremost based on cinematic operations, such as the position and movement of the camera, framing, light, music, editing, etc. The acting of human beings in film is not any different from other "actions" - they all occur on a cinematic level, as André Bazin points out in his essay on film and theatre (Bazin 1967). In contrast to Nō, in Western film tradition living and non-living beings are categorically distinguished. In $N \bar{o}$, human (actors) and non-human beings (props, costumes, elements of stage, etc.) are brought by stylisation to a level of a specific artificiality, unifying what is happening and appearing on stage. From that necessity arises a specific reality and aesthetic of film, which might be seen as a particular beauty of film.

\section{The Appearance in Ikebana and in Film Editing}

In the 1920s, Lev Kuleshov investigated the effects of the facial expression of the actor and its origins, believing not so much in the work of the actor as in the semantic effects of film editing. In a famous experiment, he juxtaposed the image of an actor with three different motifs: a soup, a coffin and the picture of a sleeping woman (in some sources, it is a child). As a result, Kuleshov claimed that, in each picture, the same face "showed" different expressions: appetite, sorrow or lust. This, according to Kuleshov, demonstrated that expression and meaning in film do not rest within one picture but are generated from the combination of pictures. The Kuleshov effect, which can reveal three different emotional expressions on the same face, can also be described in a different way with the principles of kire. First of all, there are not three but, rather, four motifs: a soup, a coffin, the picture of a sleeping woman and the face of the man. They are each cut off from their original situations and meanings so that they can combine with other pictures and generate different meanings. They do not relate to their original contexts anymore, similar to the singular flower in ikebana, which does not relate to the meadow anymore. This openness creates an ambiguity, in that the images need to be able to be assembled in new relations and to let new entities emerge. However, when describing the Kuleshov effect, we often forget that a picture of soup itself is not primarily a symbol of hunger, just as the other motifs (coffin, sleeping woman) are not symbols unto themselves. There are numerous relations that

10 In recent Marvel movies, there are similar, though, of course, more spectacular, effects with movement in frozen pictures. For example, Deadpool (2016), there is a fight scene on a bridge, in which the motion of the action suddenly stops, but the "camera" continues moving through the frozen action. Thus, we feel the spatiality of the cinematic picture by seeing objects such as bullets in the air or halted falling figures from various angles. Quite similar are the effects of the certain scenes from the X-Men series. There, we view reality through the angle of Quicksilver, a character who is able to move so quickly that, according to him, the environment looks as if it is frozen. However, those examples are only playing with what is characteristic in the cinematic image itself as form. 
occur and operate in a picture and that can give rise to, or manifest as, symbols or motifs, but it is also possible that no motif whatsoever arises from a picture. The question is as follows: how does a picture become a symbol or a motif? Normally, we say that the context of a film's picture is the other pictures surrounding it, the context of a montage sequence is other montage sequences of the film, and the film itself can be seen in the context of other films. It is important to note that in film, the cut is operant in the picture itself and in the picture's constitution as such. Kire thus is not so much a question of knife or camera-it continues in the image and is operating in the combination of elements. The flower in ikebana is different from the flower in the meadow. It is not only the combination with other flowers or twigs with which it is put together that produces the flower in a new way in ikebana. The cut already transforms the flower and continues working on the transformation of the flower in the ikebana-arrangement. Similarly, the image of the film, similar to the image of the Kuleshov effect, is created yet by the cut. There is no reference but the cut in creating the symbol or the motif. The concept of kire does not know a Platonic heaven. There is not a flower existing if not the flower created by cut. It is conceivable to create also the flower in the meadow by cutting it, but this cut is happening, as it were, "at degree zero": the cut-without-cutting creates the flower in the meadow. What at first glance sounds highly sophisticated is, in fact, similar to the paradoxical theory of absolute nothing as the origin of fullness. It is impossible to be explained in terms of distinction as a logic system but, rather, in degrees-one must admit and consider change, flow and difference. The point is that we never get the flower for good. We follow it in its movements, or more precisely, we follow the flower in following the eternal flowing of space and time.

\section{Flowing Movements, Entities and Fragments}

Kire allows us to describe aesthetics as occurrences: the occurrence of $N \bar{o}$, the occurrence of ikebana and the occurrence of film. From here emerges an aesthetics of occurrence and appearance as an endless flow of cuts-this is the meaning of the continuity of the cut in the term kire-tsuzuki (the "cut continuity").

A twig could be seen as a twig, but it could also be seen as part of a branch. A branch could be seen as part of a tree. A tree could be seen as an element of the forest. A forest could be seen as part of a landscape. And so on. The twig, the branch, the tree or the landscape themselves are, as entities or as occurrences not composed. They turn themselves into elements: the twig is an element with respect to the tree; the tree is an element with respect to the woods. The principles of kire do not know absolute elements or atoms as basic entities. The elements of each arise from appearances, pursuant to the kire-tsuzuki. The relations between the elements come from that cutting and continuation. The frame and the cut of the cinematic image define the whole and its elements. However, in every movie, the elements and the whole are always reversible. There is never a fixed centre, even if it is not moving, just as in most mainstream movies. The centre might move every second, causing a Hokusai frog's, or a cat's, point of view to arise; every second a cut (in the sense of kire) might occur. The universe opens a different angle never seen or thought of before: Rashomon is always possible in every movie. What comes to mind are so-called mind-game movies or certain horror movies-movies where changing perspectives and angles are destabilising the centre of narration and are shifting the centre of the cinematic universe.

What might sound like classical semiotics or structuralism is, in fact, something else: structuralism considers meaning that arises from the structural relation between elementary units. However, the aesthetics of kire-tsuzuki do not describe combinations; they describe the flow and the operation of appearance or, rather, the arising of aesthetical existence and liveliness in the realm of reality. In terms of kire, the take of a film receives existence and liveliness not from its link to what we, in occidental terms, conceive as the representation of reality: the picture receives its aliveness not from the aliveness of the represented object in the picture. The appearance, the image itself, is alive-or not. The picture can fail in the same way as ikebana or the walking in $N \bar{o}$ theatre can fail. 
Thus, there is a question of life and death in the aesthetics of kire-only from that can we begin to understand beauty that is in contrast to what is nice, picturesque, cute or pretty. Beauty in the horizon of kire is not a question of delight or pleasure; it is rather shocking and horrifying, related to that what we call in occident aesthetics the sublime. ${ }^{11}$

\section{Conclusions: The Beauty and the Blossom of Film}

The flower in ikebana is connected with the reality of ikebana. Likewise, the image within a film is connected with its cinematic reality. Both the flower and the cinematic image arise in a new realm of time and space. They both generate and become a new and singular reality. The aesthetics of kire-tsuzuki are rather aesthetics of creation and of existence but not aesthetics of representation. They can open an angle to describe the way in which the cinematic image exists. The idea of essence in the aesthetics of kire is crucial, not a concept of expression. However, the essence is different in every case, as it is the form of existence revealed and generated at the same time. This essence, which results from the operations of the cut, must not be regarded as equivalent to Plato's eternal ideas underlying the things. The essence in the aesthetics of kire is a paradoxical combination of universal eternity on the one hand and uniqueness and singularity on the other. Thus, the dimensions of time in kire are simultaneously everlasting and actually present. Moreover, from the moment of the way the flower, the walking or the image arises-by kire-the chronic and spatial dimensions of the universe arise. In Japanese and Chinese traditions, we find more often thinking in terms of energies (chi or $k i$ ) than in terms of time and of space, as we are still used to thinking in the Occident. However, in traditions of East Asian thinking, space and time are also realised by the existence of beings (objects, animals and humans). This is surprisingly similar to cinematic reality.

The concept of kire is an aesthetic in contrast to concepts of imitation, representation or reflection. Kire opens a horizon beyond the fundamental distinction between reality and imagination that always underlies occidental concepts of aesthetics, such as mimesis, simulation, representation, copy or illusion. Thus, kire offers a concept of beauty that is related to the concept of eternity: from the cut, the picture (or in ikebana, the flower) arises in the realm of an eternity and offers a reality that never existed before. This is an aesthetic reality that unifies artificiality and naturality. The seeming contradiction results from modes of thinking underlying occidental categories and logic. In terms of an aesthetics of reception, for example, it is a paradoxical constellation of temporal dimensions, because we are used to distinguishing the spheres of creation and reception. However, the aesthetics of kire describe a realm of creation, of apparition and of being, which affects us to such an extent that we become aware of the present presence, and we experience the simultaneous presence of different dimensions, which occur in a picture "living" that way. Reception, creation, production and presence are flowing through different agencies. We experience and observe the transformation, instead of understanding meanings or expression.

To come back to the tea: the different practices of tea infusion in Chinese, Japanese and European cultures must not be seen as mutually exclusive, with respect to kire-tsuzuki. In fact, they are very much compatible. They are simply different ways of treating the same object; however, when taking into account what we have discussed above, the comparison shows that the same object is always different. The existence of the tea changes depending on the practice of infusion. This comparison of cultural traditions allows us to see the reality of tea as different and diversified.

Applying the logic of kire-tsuzuki as introduced above, we gain perspectives for describing the cinematic image beyond representation. Rather, we are able to examine the expression of meanings as occurrence, its appearance and presence, as well as its transformation or "flow".

11 The most important authors of the sublime in modern Western philosophy are Anthony Ashley-Cooper, the third Earl of Shaftesbury, Edmund Burke, Immanuel Kant and Friedrich Schiller. 
In building upon the ideas set out in this paper, it would be important to expand the spectrum of terms by introducing other concepts from different cultural horizons (such as Japanese aesthetics). For example, the categories of Okakura's tea theory mentioned above were introduced by Kayo Adachi-Rabe into film theory a few years ago and include emptiness (kyo), asymmetry (suki), shift (zure), lack (kizu), deformation (yugami), void ( $m u$ ) and virtuality $(k \bar{u})$ (Adachi-Rabe 2016, p. 53; Okakura 2008, p. 40). ${ }^{12}$ As we can see in translating these concepts into English, and thus a Western cultural paradigm, most of the terms are still characterised by their deviation from occidental concepts. Okakura himself talks about categories of incompleteness. His Book of Tea (1906), written in the early 20th century, is addressed to a Western audience and was originally written in English, so he wrote considering Western criteria of beauty (Okakura 2008).

In the future, we must change our modes of thinking, instead understanding these terms as categories of completeness and perfection in a sense that is not related to the criteria of occidental aesthetics. Beyond the criteria of traditional occidental aesthetics, we should explore new horizons for describing aesthetics that have been arising since the middle of the 20th century, even in Western culture. We can point to, for example, the films of European cinema since the 1950s and 1960s. Japanese aesthetics have inspired Western directors ever since Japanese cinema was discovered by the Western audience around 1950. The former critics of the Cahiers du cinema, above all Godard and Rivette, were strongly influenced by the films from Mizoguchi and Kurosawa. However, recent changes in international film aesthetics are also influenced by non-Western cultural traditions-even in Hollywood productions. In Western philosophy, Gilles Deleuze and Félix Guattari, strongly inspired by Daoism, tried to develop a flowering or flowing thinking. In the last few years, the French philosopher François Jullien and others have introduced Chinese thinking in Western philosophy.

Film is not an art form essential to the West. The poetics and aesthetics of film are not rooted in occidental traditions. There might be a relevant wordplay here, even if it only works in English, in the discourse about the flower: the flower itself is an object that flows ("floating flower"-something that James Joyce seems to put forward in Ulysses) (Gabler 1984, p. 175). ${ }^{13}$ Cinematic images could thus be described as flowers flowing without form through cultures, arising in different forms, just as the tea puts forth various tastes. These cinematic flowers are putting forth endless varieties of blossoms—and the blossom, which, in Western terms, is the beauty in Asian aesthetics, could be seen as the soul in the world of the arts.

Funding: This research received no external funding.

Acknowledgments: The subject of this paper was first inspired by the conference "shintai/soma-Presentation of Bodies in Japanese Films", hosted by the Institute for Theatre-, Film and Media Studies at the Goethe-University Frankfurt/Main in July 2013, organised by Andreas Becker and Kayo Adachi-Rabe (Adachi-Rabe and Becker 2016; Frisch 2016a, 2016b). Meanwhile, I had the opportunity to elaborate on some perspectives presented in this essay. I am very grateful to Kayo Adachi-Rabe, Andreas Becker, Osamu Inoue, Mario Kumekawa, Morihiro Niino, Naoki Sato, Michi Shigeta and Teruaki Takahashi for their advice and discussions about transcultural perspectives in theorising the aesthetics of the cinematic picture. I have to further thank Gerrit Heber, Christian Wehmeier and Marcos Centeno.

Conflicts of Interest: The author declares no conflict of interest.

\section{References}

Adachi-Rabe, Kayo. 2016. Die Ästhetik der Unvollkommenheit im Teeweg und im Film. Rabbit Eye-Zeitschrift für Filmforschung 8: 41-66. Available online: http://www.rabbiteye.de/2016/8/adachi-rabe_teeweg.pdf (accessed on 13 September 2019).

12 Adachi-Rabe (2016), p. 53. Many studies on Japanese aesthetics have been published in English in the last 20 years, above all the books edited by Marra (1999, 2001, 2002, 2011). But there are not yet many reflections on these aesthetic concepts in relation to film.

13 Ulysses, $5.570-72$ 
Adachi-Rabe, Kayo, and Andreas Becker, eds. 2016. Körperinszenierungen im japanischen Film. Darmstadt: Büchner. Barthes, Roland. 1970. L'Empire des signes. Paris: Seuil.

Bazin, Andre. 1967. Theatre and Cinema. In What is Cinema? Translated by Hugh Gray. Berkeley: University of California Press, vol. 1, pp. 76-124.

Fan, Victor. 2015. Cinema Approaching Reality: Locating Chinese Film Theory. Minneapolis: University of Minnesota Press.

Frisch, Simon. 2016a. Kire - die japanische Ästhetik des Schnitts und der Film. In Körperinszenierungen im japanischen Film. Edited by Kayo Adachi-Rabe and Andreas (Hg.) Becker. Darmstadt: Büchner-Verlag. S, pp. 237-61.

Frisch, Simon. 2016b. Kire - "Reine Gewalt" im japanischen Film. Das japanische Prinzip des Schnittkontinuums (kire-tsuzuki) als Horizont für eine Theorie der filmischen Ästhetik. RabbitEye-Zeitschrift für Filmforschung 8: 79-97. Available online: http://www.rabbiteye.de/2016/8/frisch_kire.pdf (accessed on 13 September 2019).

Gabler, Hans Walter, ed. 1984. James Joyce: Ulysses. A Critical and Synoptic Edition. New York and London: Garland Publishing, vol. 1.

Gerow, Aaron. 2010a. Introduction: The Theory Complex. In Decentering Theory: Reconsidering the History of Japanese Film Theory. Kioicho: Josai University, pp. 1-13.

Gerow, Aaron. 2010b. The Process of Theory: Reading Gonda Yasunosuke and Early Film Theory. In Decentering Theory: Reconsidering the History of Japanese Film Theory. Kioicho: Josai University, pp. 37-43.

Hammitzsch, Horst. 1957. Zum Begriff ‘Weg' im Rahmen der japanischen Künste. Nachrichten der Gesellschaft für Natur-und Völkerkunde Ostasiens 82: 5-14.

Hashimoto, Noriko. 1998. Schlüsselworte in der Lehre vom Kunstweg. In Das Erbe der Bilder. Kunst und moderne Medien in den Kulturen der Welt. Edited by Hans Belting and Lydia Haustein. München: Beck, pp. 163-69.

Imai, Yasuo. 2004. Die Idee des Musters (Kata) und die ästhetische Konstruktion des Ich im japanischen Kontext. In Ästhetik Erfahrung. Edited by Jörg Huber. Wien and New York: Springer, pp. 61-77.

Iwamoto, Kenji. 1987. Film criticism and the study of cinema in Japan: A historical survey. Iconics 1: 129-46.

Kawase, Toshirō. 2000. Kawase Toshirō ga kataru Jibunshi. "Meijin" niwa naritakunai. [Toshirō Kawase about his biography.]. In Geijutsu Shinchō. Tokyo: Shinchōsha, pp. 89-92.

Manovich, Lev. 1995. What is Digital Cinema? n.p. Available online: http://manovich.net/content/04-projects/009what-is-digital-cinema/07_article_1995.pdf (accessed on 13 September 2019).

Manovich, Lev. 1996. Cinema and Digital Media. In Perspektiven der Medienkunst/Perspectives of Media Art. Edited by Jeffrey Shaw and Hans Peter Schwarz. Ostfildern: Cantz.

Marra, Michael F., ed. 1999. Modern Japanese Aesthetics. A Reader. Honolulu: University of Hawai'i Press.

Marra, Michael F., ed. 2001. A History of Modern Japanese Aesthetics. Honolulu: University of Hawai'i Press.

Marra, Michael F., ed. 2002. Japanese Hermeneutics: Current Debates on Aesthetics and Interpretation. Honolulu: Honolulu University of Hawai'i Press.

Marra, Michael F., ed. 2011. Japan's Frames of Meaning. A Hermeneutic Reader. Honolulu: University of Hawai'i Press.

May, Reinhard. 1996. Heidegger's Hidden Sources: East Asian Influences on His Work. Translated by Graham Parkes. London: Routledge.

Mitchell, William J. 1992. The Reconfigured Eye: Visual Truth in the Post-Photographic Era. Cambridge: The MIT Press.

Ōhashi, Ryōsuke. 1994. Kire. Das Schöne in Japan. Köln: DuMont.

Ōhashi, Ryōsuke. 1998. Zum japanischen Kunstweg. Die ästhetische Auffassung der Welt. In Das Erbe der Bilder. Kunst und moderne Medien in den Kulturen der Welt. Edited by Hans Belting and Lydia Haustein. München: Beck, pp. 149-62.

Ōhashi, Ryōsuke. 2014. Kire. Das Schöne in Japan. 2. überarbeitete und ergänzte Auflage. Paderborn: Fink.

Okakura, Kakuzō. 2008. Das Buch vom Tee. Köln: Anaconda. First published 1906.

Parkes, Graham. 1987. Heidegger and Asian thought. Honolulu: University of Hawai'i Press.

Satō, Tadao. 2010. Does Film Theory Exist in Japan? In Decentering Theory: Reconsidering the History of Japanese Film Theory. Kioicho: Josai University, pp. 14-23.

Semsel, George S., Hong Xia, and Jianping Hou, eds. 1990. Chinese Film Theory. A Guide to the New Era. New York: Praeger.

Semsel, George S., Xihe Chen, and Hong Xia, eds. 1993. Film in Contemporary China. Critical Debates, 1979-1989. Westport, Connecticut and London: Praeger. 
Seubold, Günter. 1993. Inhalt und Umfang des japanischen Kunstbegriffs. Philosophisches Jahrbuch 101: 380-98. Zeami, Motoyiko. 2008. Performance Notes. Translated by Tom Hare. New York: Columbia University Press. article distributed under the terms and conditions of the Creative Commons Attribution (CC BY) license (http://creativecommons.org/licenses/by/4.0/). 
Article

\title{
Japan's New Left and New Wave. An Ideology's Perspective as an Alternative to That of National Cinema
}

\author{
Ferran de Vargas \\ Department of Translation, Interpretation and East Asian Studies, Universitat Autònoma de Barcelona, \\ 08193 Bellaterra, Barcelona, Spain; ferran.devargas@uab.cat
}

Received: 17 October 2018; Accepted: 18 December 2018; Published: 20 December 2018

\begin{abstract}
Starting from the perspective that national cinema is not a neutral concept, but rather a film expression with ideological implications, in this article I will argue that what should be analysed in films is not what connects them to certain nations, but with certain ideologies. Rather than claiming the national nature of a film, it is more accurate to identify for instance elements of a national ideology underlying the film. It can be more enriching to analyse different film trends that are based on their connections with different ideologies, thus stressing their political nature, rather than highlighting cultural or geographical features in order to determine the supposedly natural outline of national cinemas. From this point of view, I consider the Japanese New Wave cinema of the 1960s and early 1970s to be a reflection of Japan's coetaneous New Left ideology. In order to illustrate this political reading of the Japanese New Wave, I focus on the analysis of a paradigmatic film: Eros + Massacre (Erosu purasu Gyakusatsu 1969), directed by Kijū Yoshida.
\end{abstract}

Keywords: film studies; ideological analysis; ideology; Japanese cinema; nation; national cinema; New Left; New Wave; Nuberu Bagu; Kiju Yoshida

\section{Introduction}

Considering that Japan's cinema has occupied in Europe and the United States a discursive position of otherness more than any other Asian cinema (Needham 2006, p. 8), it can be taken as an illustrative case of the efforts that are made by some scholars to construct an idea of national cinema and of the implications of this construction. In this article, I start with the premise that 'national cinema' is not a neutral concept, but a kind of film expression with ideological implications. I will argue that what should be analysed in films is not what connects them to certain nations, but with certain ideologies.

Authors such as Higson (2002) have criticized the 'limiting imagination' of national cinema by focusing especially on the transnationality of film production or reception and the impossibility of unambiguously determining the specific culture of any particular nation. Although this is a first step towards questioning the paradigm of national cinema, I do not only aim to highlight the limiting nature of the model, but also its non-validity. Beyond the transnational and cultural factors, I consider that what allows us to question the validity of the model of national cinema is the ideological and subjective basis that defines the national reality in its fitting with cinema. From this point of view, rather than claiming the national nature of a film, it is more accurate to identify for instance elements of a national ideology underlying the film. It can be more enriching to analyse different film trends based on their connections with different ideologies, thus stressing their political nature, than highlighting cultural or geographical features in order to determine the supposedly natural outline of national cinemas.

I consider that all artistic expression is linked to a certain ideology (or ideologies), and in order to illustrate this ideological perspective in contrast to the national one, I aim to explore the hypothesis 
that the Japanese New Wave cinema of the 1960s and early 1970s is mainly a reflection of Japan's coetaneous New Left ideology. Even though the works in English of authors such as Desser (1988), Standish (2011), and Furuhata (2013), have addressed the Japanese New Wave thoroughly, taking into account the immediate socio-political context, they are not based on an exhaustive analysis of the New Left's ideology underlying the films that make up this film trend, but they are more focused on other important aspects of the cinematographic phenomenon. As Kellner (1993, p. 55) points out, addressing film politically "means not only reading film in a socio-political context, but seeing how the internal constituents of a film also either encode relations of power and domination, serving to advance the interests of dominant groups at the expense of others, or oppose hegemonic ideologies, institutions, and practices". It is not just a matter of linking a film phenomenon with a general socio-political context, but of linking it with the ideology of a particular socio-political agent. In this case, I think it is important to explore in English the path that consists of starting with a systematic definition of Japan's New Left ideology from which to find correlative film features. In this way, the elements of the film discourse that work as means in the social confrontation of powers can be decoded.

In order to illustrate this political reading of the Japanese New Wave, at the end of the article I focus on the concrete analysis of a paradigmatic film: Eros + Massacre (Erosu purasu Gyakusatsu 1969), directed by Kijū Yoshida. Although authors such as McDonald (1983), Desser (1988), Yomota [2004] (2010), Standish (2011), and Briciu (2012), have addressed this film in depth, they have not done so based on a political reading like that proposed by Kellner. Yomota [2004] (2010, p. 51) states that "in the period between 1968 and 1972 the political vanguard and artistic experiment joined hands and together created an expression of these exalted times", 1 and he admits that "in order to understand the awareness embedded in this film, it is vital to grasp the epistemological context of the era in which it was planned and made". Based on this lack of groundwork Yomota observes, I aim to develop an analysis of Eros + Massacre in the light of its ideological reality.

\section{Nation, National Cinema and the Ideology of Cinema: The Case of Japan}

Higson (2002) questions the usefulness of the notion of national cinema because it is only possible to establish what does not define the concept, not what defines it. Indeed, if we try to define Japanese national cinema, we cannot do it based on the production side due to the existence of cases such as Ernesto (Erunesuto 2017), a film co-produced by Japan and Cuba, directed by a Japanese filmmaker (Junji Sakamoto), starring a Japanese actor (Jō Odagiri) talking in Spanish (with a strong Japanese accent even though he plays the role of a Bolivian), set in Cuba, and whose main theme is Cuban history. Nor can we define it based on the reception side since there are films produced in a nation with greater success abroad.

The impossibility of defining the 'national' aspect of a cinema through production or reception due to transnational cases means that some authors end up trying to focus on the content of films, or even to set some cultural features that are intrinsic to a nation in order to link them to certain films made in that very national space. For instance, according to Hill, what allows us to talk in terms of national cinema within the context of Britain is the capability of "registering the lived complexities of British 'national' life" (Hill 1996, p. 16) and of working with or addressing 'nationally' specific materials (Hill 1992, p. 16). On the other hand, according to Ramlochand (2006, pp. 21-22), national cinema is the whole set of films made in a particular spatial context, but while he admits that it cannot

1 Although most of the filmmakers who made up the Japanese New Wave did not consider themselves to be members of a movement, there are shared objective film features that allow us to speak at least of a cinematographic trend. Desser (1988, pp. 4-5) talks about the Japanese New Wave in terms of an 'avant-garde movement' because, according to him, it was a set of films produced with a particular disjunctive form compared to previous filmic norms, with a political stance and with a concrete end. Also Adler $(2009$, p. 14) states: "That the term New Wave has continued to be used to this day as a generic designation for a cluster of innovative Japanese directors is not problematic per se, on the condition that the simplistic equivalence with the innovations of the French cinema of the late 1950s and early 1960s that the Japanese Nüberu Bāgu was initially designed to convey be nuanced". 
be defined in terms of a singular mood, he paradoxically claims that the best candidates to define Japanese national cinema are those films that reflect the sociocultural and religio-philosophical legacy of Japan; a legacy that is characterized according to him by a non-logocentric and non-conclusive view, a mood of sadness and resignation, and a strong sense of impermanence (ibid., pp. 114-15). However, it should be noted that these kinds of exercises are too arbitrary and can be essentialist.

In this regard, can we consider Ernesto to be a part of Cuban national cinema due to its nationally specific theme, in spite of the strong Japanese involvement in its production? Moreover, if we take into account that a film such as Story of the Loyal 47 Ronin (Genroku Chushingura 1941-42), considered by Burch (1979) as an example of paradigmatic Japanese cinema, was one of the biggest commercial failures of Kenji Mizoguchi's entire career as a filmmaker, can we still consider it a component of Japanese national cinema? What is the nation but the people that make it up and thus its audiences?

Raine's (2002, pp. 60-65) criticism of Stephen Prince's study on the cinema of Kurosawa is very illustrative of the arbitrariness involved in determining certain characteristics intrinsic to a nation and national cinema. According to Raine, in order to conclude that Kurosawa's struggler worldview was fundamentally marked by Japanese indigenous traditions, Prince highlights the influence on his films of alleged bushido values that were received from his military father, and of the legacy of Japan's rebellious agrarian monks and peasants as well as legendary samurai personalities. Nevertheless, Raine points out that the Japanese military was one of the most modern and western considered parts of the nation during the Taisho period (1912-25), that some of the values that Prince associates with bushido could be also associated with Prussian transnational influences, and that modern left-wing movements could have had a significant influence on Kurosawa's struggler worldview.

These kinds of ambivalences, present to a greater or lesser extent in any cultural production, make it too difficult to define national cinema. Obviously, the term 'national' comes from that of 'nation', so it seems logical to think that the first step to find a definition of 'national cinema' is to figure out what a nation is. Nevertheless, it is the very definition of 'nation' what paradoxically causes the impossibility of establishing the meaning of 'national cinema', and not only the problem of transnational production/reception or national essentialisms. Therefore, what I propose here is not only a questioning of the usefulness of the national cinema model but also of its validity. One of the authors who has achieved the greatest consensus in theorizing the concept of nation, Gellner (Gellner 1988, p. 7), states the following:

Two men are of the same nation if and only if they recognize each other as belonging to the same nation. [ ... ] Nations are the artefacts of men's convictions and loyalties and solidarities. A mere category of persons (say, occupants of a given territory, or speakers of a given language, for example) becomes a nation if and when the members of the category firmly recognize certain mutual rights and duties to each other in virtue of their shared membership of it.

The fundamental idea of this conceptualization is that what determines the existence of a nation is not a spatial component or some common characteristics that aroup of people shares, but the fact that these people subjectively decide to use that space and those characteristics in order to constitute themselves as a nation; namely, a set of people who, due to whatever historical circumstances, believe they have the right to sovereignly govern themselves in a specific territory.

Thus, a nation is something invented, unlike, for instance, a class, which is the product of our objective position in the relations of production. However, it does not mean that the nation is not real. It is important to highlight the nuance made by Anderson (Anderson 2006, p. 6) when criticizing the standpoint that "assimilates 'invention' to 'fabrication' and 'fallacy', rather than to 'imagining' and 'creation'". The fact that a nation is an imagined community does not mean that it is invented in an exclusively subjective, conscious, manipulative, and unilateral way; it is a complex and changing creation that is based on some objective elements, and in that many agents participate with different degrees of power and different national perceptions, often in a contradictory and more or less unconscious way. 
If we rely on this conception of what a nation is, then we realize that the importance of the subjective factor makes it impossible to accurately determine the 'national' aspect of cinema. Because one can ask a person or a set of people whether they consider themselves to be from a particular nation, but one cannot ask a film or a set of films, since films are objects and not subjects. The cases of films made within the margins of a stateless nation and focused to some extent on specific materials of that nation illustrate very well the impossibility of defining the 'national' aspect of cinema. For instance, if we rely solely on the legal nationality (that is to say, the state) of a Catalan film, we could affirm that it is Spanish cinema, but we cannot affirm that it is objectively Spanish national cinema or Catalan national cinema. What we can do is determine whether the film contains a Spanish or Catalan national ideology. It is this very ambiguity of the concept of national cinema that probably leads to D'Lugo (1991, p. 131) speaking in terms of "something like a national cinema" when talking about a set of Catalan films, establishing a kind of conceptual hierarchy that reflects the existing material hierarchy between nations.

In any case, although we cannot satisfactorily define what the concept of national cinema implies, what we can do is identify and analyse national ideologies underlying several films, always taking into account the context of those films. National ideologies are based on claiming the people as a nation, and explain reality based on (or giving significant importance to) the division and relationship between nations. These kinds of ideologies can be used at the same time to construct, preserve, and strengthen certain nations (and more indirectly, to weaken others, or to counteract other kinds of divisions, such as class or gender). For instance, nationalism is a kind of national ideology that can be aimed at obtaining a state for a stateless nation, defending the state it already has, fostering the internal unity of the nation, protecting it against external or internal powers, or boosting its economy through the cultural label of its films in the global market. However, within nationalism there are several variations, such as for instance what Ko (2010) calls 'cosmetic multiculturalism' when talking about some Japanese films, a kind of ideology that welcomes cultures other than the dominant one, but only appreciates them as depoliticized 'objects' of consumption. Sovereignism, however, is another national ideology that is different from nationalism and seeks to support the sovereignty of a nation, the right of its people to decide if they govern themselves in one way or another, with or without a state, and with more or fewer external influences.

In this sense, the work of Davis (1996) about the sense of Japaneseness projected by many pre-war films made in Japan is very illustrative, because he interprets it not as a sign that serves to define the objective outline of Japanese national cinema, but rather as a film aesthetic that served the interests of Japanese nationalism. He calls this national aesthetic 'monumental style', and points out that it is characterized by a canonization of Japanese history, a sacralization of selected Japanese culture and traditions, an emphasis on indigenous art forms and design, long takes and long shots, slow camera movements and narrative, ceremonial acting and settings, and an epic and reverential tone that marks the themes. These 'monuments' to Japaneseness in the form of films operated mainly as tools for the mass mobilization in support of the colonialist war in Asia, and against the cultural influence of the west. The films that were made by Mizoguchi during World War II, such as, for example, the aforementioned Story of the Loyal 47 Ronin, can be considered as belonging to this kind of aesthetics.

However, Gerow (2009, p. 187) points out that Davis' analysis of the Japaneseness of pre-war films does not take into account important elements that are beyond the film's textuality, such as the mass consciousness and culture reflected in the audiences, which a lot of box-office failures of monumental style films reveal, or the debates and disagreements during the war about what Japaneseness is and what represents the Japanese nation; films of monumental style, in fact, were cited by some critics of the time as examples of what should not represent the nation. Nevertheless, Gerow's criticism should not lead us to discard the fundamentally ideological nature of national cinema. Instead, it should lead us to conclude that there is not a single national ideology and thus a single notion of national cinema for each nation in each historical moment, nor a univocal and strictly conscious aesthetic process of manipulation to serve the interests of a certain regime, but rather a dynamic relationship of powers among multiple agents with different perceptions and grades of consciousness about what is national. 
If questions such as "what film characteristics make a cinema national" or "to which national cinema do particular film or film features belong" are not as useful to gain an objective understanding of cinema as to subjectively shape certain national ideologies, replacing them with questions such as "what ideology (or ideologies) are certain films or film features aligned with" or "the interests of which social group(s) are promoted by certain films or film characteristics" can lead to a more fruitful epistemological field.

While determining the outline of a national cinema implies creating a national ideology, determining the ideologies underlying films mainly implies generating a political view of cinema: it is about understanding how different social groups see the world, how they seek to transform it or prevent it from transforming, how they are placed in the network of power relations that constitutes every society, and how all of this is reflected in films.

An ideology can be understood as the dynamic set of explicit expressions belonging to a doctrine (theories, novels, manifestos, speeches, films, paintings, etc.), of socializing or ritual practices and institutions, and of experiential and subjective perceptions of reality, which are linked to a greater or lesser extent to the interests of specific social agents in a socially significant power relationship or struggle. Part of this definition is based on the three vectors Žižek (1994) distinguishes in ideology. However, my definition is based more on a sociological tradition than on an epistemological one, since it is concerned about the role of ideologies in society instead of trying to discern whether an ideology is more or less adjusted to an objective reality. Moreover, here, ideology is not understood as something related only to social classes, and even less to the ruling class only, but more broadly to social agents.

In order to analyse any explicit expression belonging to a doctrine (in this case, films or film features), first we should identify the ideologies of the main social agents that make up the power network of the historically specific society from which the very explicit expression appears, and analyse at least their general characteristics. Subsequently, we should look for lines of convergence between the characteristics of the ideologies, and the explicit expressions. In this sense, in the field of cinema, this political perspective is not focused on looking for lines of convergence between films and a specific national culture or remote history, but between films and the ideologies that arise from the different human groups that make up societies in their immediate historical context.

From this point of view, just as there are certain films or film features that in their context can be aligned with national ideologies that favour (very often in a complex, contradictory, indirect and coded way) the interests of certain social agents, there are also films or film features that can be aligned with other ideologies that favour the interests of other social agents. For instance, just as the monumental style described by Davis was a type of aesthetics in line with the Japanese ultra-nationalism of the war, favouring the interests of the imperial regime (which was a social agent composed of multiple agents), later in the 1960s and 1970s the Japanese New Wave was a cinematographic trend aligned in broad terms with the ideology and interests of Japan's New Left movement (also a social agent composed of multiple agents, and consequently complex and sometimes contradictory). Regarding this matter, in order to carry out a political reading of the Japanese New Wave, first we have to consider the historical existence of Japan's New Left and analyse its ideology.

\section{New Left Ideology and the Formation of the Japanese New Wave}

The seed of Japan's New Left emerged in 1955. Forced by Moscow and Beijing, the Japanese Communist Party (JCP) had been sending student guerrillas to rural areas to trigger the revolution for five years, and forced again by the international communist leadership that year, it demanded that violence be renounced as a political means in order to focus on the ballot box. As a consequence, many young communists who had sacrificed their personal future in the hope of playing a part in the revolution felt betrayed by the party. However, some of those young militants did not assume the position of victims of the party, but admitted their own individual responsibility in having engaged the guerrillas. Those same young communists, influenced by important events, such as the Sunagawa Struggle (1955-57) and the Hungarian Revolution (1956), and increasingly opposed to the rigidity 
and authoritarianism of an aged JCP, in 1958 ended up creating a new political organization, the Communist League, better known as the Bund.

The Bund advocated for intensifying the subjective commitment of social movements to make the revolution happen in the short or medium term, against the JCP's 'two-stage revolution' theory, which considered that the objective factors did not allow the revolution to happen yet, and that prescribed the need to fully develop the modern structure and superstructure of the capitalist system (especially before 1950) and to get rid of the alleged situation of Japan as a United States' semi-colony (especially from 1955 onwards), before being able to implement socialism.

What is known as Japan's New Left burst onto the public scene at the end of 1959 when the Bund started heading the massive protests against the renewal of the Treaty of Mutual Cooperation and Security Japan-US, popularly known as Anpo, which reached their point of maximum confrontation in June $1960 .^{2}$ The general spirit of the protests, which was in line with that of the institutionalized left and the progressive intellectuals, was a fear that the Japanese people would become victim of a return to a 'premodern' past (related to feudalism), a totalitarian regime (related to fascism), and a new war in their own land. That is, the general spirit was defensive, aimed at protecting the so-called post-war's 'peace and democracy' system. By contrast, the New Left, in minority despite its relative leadership, had an offensive vocation: it considered that system to be a fallacy, arguing that there had never been true peace and democracy in post-war Japan, and instead of basing its action on the fear that the people would become a victim, it attacked capitalist liberal democracy as well as what it considered to be Japanese complicity with US imperialism and not submission.

For Masao Maruyama, one of the most important intellectuals of the time, the 1959-1960 struggle was a success despite the eventual renewal of Anpo, since Japanese civil society had demonstrated for the first time its great ability to mobilize outside the state. According to him, the humanistic values that progressive intellectuals had been fostering during the post-war era had made the Japanese into a more rational and modern society. Instead, Takaaki Yoshimoto, one of the few intellectuals who positioned himself in favour of the New Left (and one of the most influential in the later development of this movement), considered that modern alienation was the real driver of protests and not the ideological 'fantasies' that progressive intellectuals harboured about the progress of modernity. Both Yoshimoto and the New Left shared a strong feeling of defeat after the renewal of Anpo. ${ }^{3}$

It was from 1965 onward, after the beginning of the US bombing against Vietnam with Japan's logistical support, when the feeling of being victimizers and not victims spread among Japanese social movements. This feeling was heightened by the fact that Japan had become a powerful economic power in the world, which was also related to the profit extracted from wars within the context of the Cold War. At the same time, the memory of World War II, of fascism, and of the post-war misery was dissipating from generation to generation, so the defensive attitude based on the fear of becoming victims of the circumstances was weaker than some years ago.

The inspiring example of the Vietnamese people resisting against the greatest military power in the world, the US, imbued many Japanese activists with a spirit that superimposed subjective determination to adverse objective circumstances. However, since war did not directly harm Japanese citizens, the commitment against it was based on an exercise of subjective responsibility and awareness. At the same time, the increasing material abundance that was making the Japanese a consumer society diffused class divisions superficially, and since the ways of oppression were less direct and the enemies of the left less palpable, the focus was increasingly on alienation as a form of oppression and on individual self-transformation. More and more Japanese activists saw themselves not as victims of the

2 The term 'New Left' is used retrospectively, since it was not until 1969 that it started to be widely used by the press in Japan (Andrews 2016, p. 92). During the 1959-1960 struggle against Anpo, what we today know as the New Left was still fundamentally the Bund and also, secondary, the Japan Revolutionary Communist League (JRCL).

3 For more information about Yoshimoto's theory, see: Yasko (1997), Kelman (2001), Murakami (2005), Yang (2008), Cassegard (2008), Kersten (2009) and Noonan (2012). 
system but as members of it, sometimes in a position of power in relation to the masses, and therefore they saw the need to question their own position as subjects and to transform themselves to transform the system.

The emergence in Japanese society of such a spirit, which to some extent was already in the genes of the New Left since its seed emerged in 1955, provided this movement with a fertile field to spread its postulates. Within that context, the New Left became strongly ingrained in the movement against the Vietnam War through radical political parties and a platform that was created in 1965 under the name League for Peace in Vietnam, abbreviated as Beheiren, and in universities through the so-called Joint Struggle Committees, better known as Zenkyōtō, a set of assemblies and student organizations that organized the mass occupations and strikes on the most important campuses in Japan during 1968 and 1969.

Although we cannot refer to Japan's New Left as a monolithic or completely coherent entity, since it came to be made up of dozens of groups, and nor can we refer to it in static terms, since it underwent many changes over time, we can find in broad terms a line of ideological continuity. Generally speaking, Japan's New Left ideology was characterized by a protagonism of youth, a focus on alienation as an important form of modern oppression (the Soviet socialism model showed that alienation could also rule in a modern system despite not being strictly capitalist) that held the potential of political rebellion, a scepticism about or at least a critical look at the idea of modernity and lineal progress, an emphasis on individual self-transformation ${ }^{4}$ and on carrying it out through subjective concrete actions rather than ideological discourse from above, an ultimate responsibility of the subject over objective circumstances, and a valorization of forms of irrational behaviour (for instance resorting to violence as pure and existential political action).

The Japanese New Wave film trend developed in parallel to the development of Japan's New Left political movement. One of the biggest film production companies in Japan, Shōchiku, launched a new policy under the name of Nüberu Bāgu (the Japanese pronunciation of the French term Nouvelle Vague), through which it tried to attract younger audiences by allowing young filmmakers, such as Nagisa Oshima, Masahiro Shinoda and Kiju Yoshida to direct their own films. This film policy was launched in 1959, just when the struggle against Anpo was taking shape, and those new young directors were influenced by the rebellious political situation their country was going through, feeling a certain degree of affinity for the New Left as a result of the vitality and renewal the novel movement entailed. At first they tried to develop an avant-garde cinema under the tutelage and limitations that are imposed by the system of big companies, influencing other filmmakers outside Shōchiku. However, independent film production companies proliferated progressively (young avant-garde directors abandoned big film production companies just as young radical leftists had abandoned the institutional left), and from the second half of the 1960s avant-garde filmmakers started to have the freedom to make their own cinema without the dictates of the majority market, radicalizing experimentation. This process of cinematographic radicalization coincided with the parallel process of radicalization that was experienced by the political New Left movement from the beginning of the American bombings against Vietnam in 1965, and it reached its peak in the late 1960s and early 1970s with the influence of the powerful student revolts.

Just like the case of Japan's New Left, although we cannot refer to the Japanese New Wave as a monolithic or static trend, we can identify a set of general continuities. In turn, these features can be linked in broad terms with the characteristics of the New Left's ideology. I aim to illustrate this through the ideological analysis of a paradigmatic film of this trend, Eros + Massacre, and especially one of its most important sequences.

4 For more information about the New Left's notion of self-transformation see Ando (2014). 


\section{Eros + Massacre as a Reflection of Japan's New Left Ideology}

Several English works have addressed Eros + Massacre, legitimately taking into account different aspects of the film. McDonald (1983) focuses strictly on aspects of the film's content and form, and affords some cinematographic context; Desser (1988) adds a deep historical-political and broader artistic context and situates the film within the Japanese New Wave phenomenon; Yomota [2004] (2010) points to the direct connection between the political vanguard and the artistic experiment between 1968 and 1972 that produced an aesthetic unconscious particular to that era, and suggests that this is a field to be explored through a necessary grasping of the epistemological context of the film's era; Standish (2011), in turn, adds an extensive intellectual-philosophical context of the film; and, Briciu (2012) offers a reading focused on a gender perspective. What I aim to do here is to provide an ideological analysis of the film exploring the connection between the Japan's New Wave and New Left.

Although, from 1965 Yoshida produced his own films and could therefore experiment with the cinematographic medium, it was from 1968, with the filming of Eros + Massacre, that he reached full autonomy to take his experimentation to the extreme, since his works began to be screened in the cinemas of the independent film production company Art Theatre Guild (ATG) instead of the big film production companies.

The film does not have a clear axis in terms of plot. It is composed of a chaotic fragmentation of barely connected images, with a confused juxtaposition of past and present, imagination and reality. Through this deconstruction, Yoshida expresses his worldview in line with two important conceptions of Japan's New Left ideology. First, this rejection of a linear and objective narrative can be considered to be in line with the attack that the New Left made of the uncritical view of linear progress held by the old left. According to this criticism, both the JCP and the post-war progressive intellectuals had a simplistic view of Japanese history divided schematically into pre-modernity and modernity, and they considered that Japan had not yet fully entered the second stage. From this old left point of view, one of the tasks of the parties and the intelligentsia should be to modernize the masses from outside in order to develop subjectivity (shutaisei) and rationality in the Japanese. Nevertheless, the view of the most libertarian ${ }^{5}$ sectors of the New Left differed in three fundamental points: first, Japan was ready for a revolution without having to go through supposed previous stages; second, the left should consider the masses as they are and not ideally as they should be; and third, the inculcation of an ideology in the people from above limited their autonomy (jiritsu) and consequently their subjectivity. The second conception of the New Left in line with Yoshida's deconstruction is directly related to the first: the anti-discursive form that the composition adopts (in the sense that it renounces creating meaning) suggests that Yoshida rejects forcing an ideology onto the viewer from the position of the director, and that he aims to foster their subjective involvement in the film.

Although the film does not strictly have a main character, Eiko is closest to the centre of the film's complex network of dispersed interrelations. She is a young woman living at the end of the 1960s. Immersed in a state of deep alienation, she is unable to have a satisfactory sex life with other people, yet she has an insatiable desire that she only manages to calm through masturbation, which leads to her prostituting herself in her eagerness to experience an awakening of her body. It is common for Japanese New Wave films to use sexual matters as a means to juxtapose the individual with authority and its taboos, which is also in line with the New Left ideology. While films that were in line with old left ideologies often expressed the subjectivity of the main characters through romantic love, representing the spiritual bond between lovers as based on free will as opposed to premodern obligations to the nation and family, the most libertarian sectors of the New Left criticized the idealizations or 'collective fantasies' (a Yoshimoto term) made of the people, such as the idea of romantic love as a sign of

5 By 'libertarian' I mean the sectors of Japan's New Wave that most questioned authority and hierarchy and most fostered spontaneity and individuality, such as the assembly structures of Beheiren and Zenkyōtō and thinkers such as Yoshimoto Takaaki, Tanigawa Gan or Tokoro Mitsuko. 
modernity and freedom. Alienation, more than ideas, was from this point of view the driving force of individual action, containing the potential of revolutionary action. In films, this alienation could be portrayed by frustrated sex and erratic behaviour based on desires and fears more than rationality, convictions, and goals, refusing to project an image of how the characters should be. This, in addition, breaks with the sentimental empathy with the characters, thus fostering the autonomy of the viewer to reflect subjectively, in line with the autonomy that the most libertarian sectors of the New Left claimed for the masses.

Faced with her sexual impotence, Eiko seeks solutions in the history of the anarchist martyrs Sakae Osugi (1885-1923) and Noe Itō (1895-1923) ${ }^{6}$ and their implementation of the theory of free love. There are similarities between the ideas of these historical personalities of the Taishō era (1912-26) and the ideas of the most libertarian sectors of Japan's New Left at the end of the 1960s, since in both cases the idea prevailed that the self-transformation of people in their immediate relationships contributed to broader social transformations.

The most important sequence of the film, which lasts almost the last hour of footage, shows three totally different versions of the same historical event: that known as the Hikagejaya Incident (or Hayama Incident) of 7 November 1916, in which, according to the official history, one of Ōsugi's lovers called Ichiko Kamichika (1888-1981), whose name in the film was changed to Ichiko Masaoka, injured him with a dagger driven by jealousy towards his other lover Itō.

In the first version, Masaoka and Ōsugi are in a room and get into an argument about their love triangle. As in the whole film, many shots have a de-centered composition, in which the characters are in a minor space, often even marginal, within the set of elements of the frame. According to Burch (1979, p. 348), this is a strategy borrowed from Japanese traditional art. Burch's consideration is a good example of an ideology that is aimed at the formation of a national cinema. He finds the reason for decentralization in the cultural roots of Japan and its remote history, instead of its contemporary context. From an ideological analysis of cinema, it is more accurate to conclude that decentralization is a strategy in line with the New Left, in an anti-humanist and anti-dualist perspective that places the individual as a part of a totality of relations and not as a subject rationally confronted with the objective world. Moreover, in this type of frame the viewer is not told where to fix their attention or what compositional meaning to deduce, thus fostering their autonomy and subjectivity.

Shortly after the argument, while Ōsugi is sleeping, Masaoka stabs him. Afterwards, both of them fight throughout the house with increasingly theatrical movements. The scene's high point of theatralization occurs when the shōji (sliding paper doors) collapse one after another as Ōsugi passes through them until he lies still on the floor. In this case, a national cinema perspective could conclude that there is a direct influence of traditional Japanese theatre, while considering the anti-realistic staging. Nevertheless, although this influence may be true, it is rather indirect, mediated by the influence of the avant-garde post-Shingeki theatre of the 1960s, which used techniques that are considered premodern from kabuki, noh, and bunraku valorizing the irrational and generating a Brecthian distance between the play and the viewer fostering their autonomous reflection. From an ideological perspective of cinema, these strategies are in line with the coetaneous Japan's New Left, considering its questioning of the infallibility of the rational and the modern, and its fostering of the autonomy of the masses.

In the second version of the incident it is Ōsugi who, after stating that "revolution is nothing other than self-denial", ends up forcing Masaoka to stab him (The sentence said by Ōsugi recalls the text that appears at the end of the New Wave film of the same year Funeral Parade of Roses [Bara no Soretsu]: "The spirit of an individual reaches its own absolute through incessant negation"). It is as if,

6 Sakae Ōsugi was an anarchist known for his theory of free love, which attacked the Japanese family model and monogamy as institutions that supported private property and state power. Based on this theory, he had several lovers during his life. Noe Itō was an anarchist known for her feminist advocacy for free abortion and prostitution arguing that women are the only owners of their body, and for her call for everyday practice as a means to fight the system. Ōsugi and Itō became lovers and they were assassinated by military police in 1923 after the chaos following the Great Kantō Earthquake. 
with this self-inflicted attack, Ōsugi admitted that the renunciation of one's self and the acceptance of error (in this case error in the implementation of free love), and not the mere claiming of one's own ideas, was the only valid way of revolutionary praxis. The New Left's idea of autonomy (jiritsu), applied in the film through the aforementioned means of anti-narrativity or anti-discursivity, the focus on the alienation of the characters and the refusal of sentimental empathy, the instability of the camera and the decentralization of the frame, the theme of everyday and personal implementation of free love as a revolutionary practice, and the theatralization, is directly linked to the notion of self-denial (jiko hitei). From the most libertarian point of view of Japan's New Left, in order for the masses to have autonomy, the political subject must subjectively deny themselves, self-questioning their own position in the network of power relations, attacking oneself as a part of the ruling system in order to transform that very system, self-questioning their legitimacy and objectivity to transmit ideological messages to the people and lead it, and prioritizing direct and daily action above the discursive expression of an internal and essential self. In this sense, this stabbing scene recalls the following words of Yoshida [1969] (2010, p. 16) himself in his essay "My Film Theory. The Logic of Self-Negation" (Watashi no eigaron. Jikohitei no ronri 1969):

Our education tells us that creating is equivalent to telling or portraying something, and having been trained this way, in the process of destruction we accidentally come upon the conservative self that informs our subconscience. The weapon that I have grasped for my opposition becomes a sharp knife aimed towards the not yet awoken parts of the self. I have ended up fighting the things I turned into my own shackles.

The image of the knife against oneself is the utmost expression and symbol of self-denial, as it was the exaltation by Japan's New Left of the martyrs who sacrificed their lives during the 1960s, such as Michiko Kanba in 1960 (a student killed during the protest against Anpo), Yui Chunoshin (an Esperantist who set fire to himself in protest against the bombing of Vietnam), and Hiroaki Yamazaki (a very young student killed during a protest at the Haneda Airport against the Prime Minister Sato travelling to South Vietnam) in 1967. Also, the anarchists Ōsugi and Itō represented in Eros + Massacre were martyred when they were killed by the imperial authorities in 1923.

The idea of self-denial (related to self-transformation), with roots in the philosophy of the Kyoto School, later developed by Leftist philosophers, such as Katsumi Umemoto and Takaaki Yoshimoto , consolidated during the Vietnam War, when a lot of Japanese adopted a victimizer consciousness replacing that of the victim. This consciousness reached its peak during the student revolts between 1968 and 1970, when a lot of university students questioned their position as members of an elite, as reflected in the following words of a medical student at the University of Tokyo:

The working people who came to visit us as patients at the hospital were suffering just as much as we were as victims of the present system of medicine in Japan. Then it occurred to us, medical students and young doctors alike, that we had been victimizers rather than victims by having complacently occupied a petit bourgeois position at the expense of the people. This recognition marked a great turning point in our movement ... We finally arrived at self-criticism and self-denial, through which we clearly foresaw the possibility of alliance with the working people.

(In Tsurumi 1975, p. 215)

But beyond the influence of Japanese thinkers such as Umemoto and Yoshimoto on the shaping of the Japanese New Wave, there is also a significant influence from non-Japanese thinkers such as Herbert Marcuse and Jean-Paul Sartre, which questions the consistency of the national cinema model. Considering the advanced development of the media, the social movements in the 1960s were globally synchronic, making up a kind of 'New Left world-historical movement' (Katsiaficas 1987). This transnational synchronicity was also reflected in the world of cinema, which allows us to consider the Japanese New Wave as part of the same global phenomenon (with its specificities): what Adamson 
(2018) calls 'New Left cinema'. ${ }^{7}$ Nevertheless, it is not only the transnational factor (the fact that, for instance, Marcuse came from a German background and Sartre from a French one) what questions the national cinema model when analyzing a Japanese film, such as Eros + Massacre, but the fact that the ideas of Marcuse and Sartre (an influential figure explicitly recognized by Yoshida) contributed toward shaping the (Japan's) New Left ideology of which the New Left cinema in general and the Japanese New Wave in particular were reflections.

In the third and final version of the Hikagejaya Incident, Itō shows up at the house just at the moment when Ōsugi and Masaoka are struggling with the dagger. However, finally, it is Itō and not Masaoka who ends up stabbing Ōsugi. He lies on the floor after the stabbing, and then Itō talks to him in a low voice: "There was no other way to go beyond you. The day you passed through me like the wind, I knew freedom. But then I realized that I was captured by you, so I had to pierce through you to gain further freedom". The scene then seems to suggest that unlike Masaoka in the first version of the incident, Itō does not stab Ōsugi because of jealousy, but in order to not feel constrained by one particular man and thus achieve the true attainment of free love, as opposed to romantic love.

The three different versions of the Hikagejaya Incident are interspersed by scenes in which Eiko and a friend of hers, a man called Wada, who also suffers from sexual impotence, are in the film studio of a lover of Eiko aged about 40, called Unema, experimenting together with a camera and a projector. These interspersed scenes suggest that the three versions of the incident are, after all, imaginary creations of the events of 1916 mediated by cinema and not recreations of the facts themselves. This is in line with the most libertarian sectors of the Japan's New Left conception that history is not an object to be approached in a purely scientific way, since it is made and imagined by subjects.

At one point, Eiko dares Wada to set her on fire. He takes out a lighter with which he has been playing on several occasions during the film, and stands still holding a small flame while watching how she spreads gasoline around the room. The small flame could symbolize the alienation of the characters, which drives action with the potency of absolute action. It is in this scene, when Eiko ends up taking the lighter and setting fire to the room with both of them inside, that the potentiality of absolute action becomes absolute action, the alienation of the small flame becomes the freedom of the conflagration: through this extreme self-denial, it seems that they finally manage to have full sexual relations.

Many other Japanese New Wave films of the time end with scenes of self-destruction, such as, for instance, Ōshima's Death by Hanging (Koshikei 1968), The Man Who Put His Will on Film (Tokyo senso sengo hiwa 1970), The Ceremony (Gishiki 1971), Shinoda's Double Suicide (Shinjū: Ten no Amijima 1969), and Matsumoto's Funeral Parade of Roses (Bara no soretsu 1969). From a national cinema point of view, it could be considered that self-destructive tendencies respond to the significant role of suicide in Japanese culture. However, from an ideological perspective it is more accurate to link these tendencies with the immediate context of the Japan's New Left ideology and its notion of self-denial.

Almost at the end of Eros + Massacre, the filmmaker Unema, to whom the film studio belongs, appears in the room. He improvises a rope with the film tape, stands on a pile of film boxes, and hangs himself. Unema could be considered as the alter ego of the director of Eros + Massacre himself, Yoshida, transmitting his conception of cinema as self-denial: cinema as a discourse that denies itself.

\section{Conclusions}

In order to illustrate the political perspective of cinema in contrast to the national one, first I have rejected the use of the concept 'national' to refer directly to cinema as a set of objects in the form of films, given the fundamentally subjective and imagined (but not unreal or fabricated) nature of nation, and I have proposed to focus on the mediation of ideology (for instance, national ideologies) as a more accurate way to frame and understand cinema, linking it to the social agents of the immediate

7 For a general perspective of the different New Wave cinemas in the world, see Gerhardt and Saljoughi (2018). 
historical time when films were made and not to natural and cultural/geographical realities or remote history. This does not mean that we cannot talk, for instance, in terms of Japanese cinema, as long as we are aware that we are referring to the nationality (state) or any other objective geopolitical space (such as an autonomous region) and not the national reality (nation) of cinema (we could even talk in terms of 'Japanese national cinema' if doing so we were referring to a cinema with a specific national ideology and not a cinema that is a direct reflection of a specific nation). Nor does it mean that we cannot talk in terms of cultural or geographical influences in cinema, as long as we take into account the mediation of the immediate historical context and its socio-political agents.

Secondly, I have explored the hypothesis that the Japanese New Wave cinema of the 1960s and early 1970s is mainly a reflection of Japan's coetaneous New Left ideology, using as a validating example the concrete ideological analysis of Yoshida's film Eros + Massacre. To do so, I have first analysed the historical existence and the general ideological features of Japan's New Left, and then I have identified the lines of continuity between Eros + Massacre as a paradigmatic example of the New Wave and the broader reality of the New Left ideology, contrasting this kind of reading with what could be national cinema's interpretations. These lines of continuity can be synthetized in the concepts of self-denial (jiko hitei) and autonomy (jiritsu), which can be considered as the main differential points with respect to the ideology of the old left.

Nonetheless, this paper has an introductory purpose and it seeks to point to a methodological alternative to read the Japanese New Wave phenomenon. In future works, it could be interesting to start from this introductory line to analyse, in a more systematic and detailed manner, key New Left concepts such as self-denial and autonomy, in their relationship with cinema. Additionally, a more in-depth analysis of the ideology of the old left and the films that make up its reflection will be required, in order to contrast it with Japan's New Left and New Wave, since these later phenomena emerged as a reaction to the previous ones, and therefore they can be better understood through a deeper analysis of this confrontation. Likewise, it will be interesting to go beyond the general features of Japan's New Left ideology and focus on more specific aspects of it, such as the political philosophy of some of its most influential thinkers, and search for lines of continuity between their explicit theories and Japanese New Wave cinema.

Funding: This research received no external funding.

Acknowledgments: This chapter is based on my PhD research entitled La Nūberu Bāgu como Correlato Artístico de la Nueva Izquierda Japonesa at the PhD Program in Translation and Intercultural Studies at the Universitat Autònoma de Barcelona (UAB). My research was supported by the Research Group GREGAL (2017 SGR 1596) as a FI grant holder (AGAUR, Generalitat de Catalunya), and by the Department of Translation and Interpretation and East Asian Studies at the UAB.

Conflicts of Interest: The author declares no conflict of interest.

\section{References}

Adamson, Morgan. 2018. Enduring Images. A Future History of New Left Cinema. Minneapolis and London: University of Minnesota Press.

Adler, Fabienne. 2009. First, Abandon the World of Seeming Certainty: Theory and Practice of the "Camera-Generated Image" in Nineteen-Sixties Japan. Ph.D. thesis, Stanford University, Stanford, CA, USA, June.

Anderson, Benedict. 2006. Imagined Communities. New York: Verso. First published 1983.

Ando, Takemasa. 2014. Japan's New Left Movements. New York: Routledge.

Andrews, William. 2016. Dissenting Japan. A History of Japanese Radicalism and Counterculture from 1945 to Fukushima. London: Hurst Publishers.

Briciu, Bianca O. 2012. Negotiating Power: Gender and Body Politics in the New Wave Japanese Cinema. Ph.D. thesis, Carleton University, Ottawa, ON, Canada.

Burch, Nöel. 1979. To the Distant Observer. Form and Meaning in the Japanese Cinema. Berkeley: University of California Press. 
Cassegard, Carl. 2008. From Withdrawal to Resistance. The Rhetoric of Exit in Yoshimoto Takaaki and Karatani Kojin. The Asia-Pacific Affairs, 6.

D'Lugo, Marvin. 1991. Catalan Cinema: Historical Experience and Cinematic Practice. Quarterly Review of Film E Video 13: 131-46.

Davis, Darrell W. 1996. Picturing Japaneseness: Monumental Style, National Identity, Japanese Film. New York: Columbia University Press.

Desser, David. 1988. Eros Plus Massacre. An Introduction to the Japanese New Wave Cinema. Indianapolis: Indiana University Press.

Furuhata, Yuriko. 2013. Cinema of Actuality. Japanese Avant-Garde Filmaking in the Season of Image Politics. Durham: Duke University Press.

Gellner, Ernest. 1988. Nations and Nationalism. Oxford: Basil Blackwell. First published 1983.

Gerhardt, Christina, and Sara Saljoughi. 2018. 1968 and Global Cinema. Detroit: Wayne State University Press.

Gerow, Aaron. 2009. Narrating the Nation-ality of a Cinema: The Case of Japanese Prewar Film. In The Culture of Japanese Fascism. Edited by Alan Tansman. Durham: Duke University Press, pp. 185-211.

Higson, Andrew. 2002. The Limiting Imagination of National Cinema. In Cinema and Nation. Edited by Mette Hjort and Scott MacKenzie. New York: Routledge, pp. 63-74.

Hill, John. 1992. The Issue of National Cinema and British Film Production. In New Questions of British Cinema. Edited by Duncan Petrie. London: BFI, pp. 10-21.

Hill, John. 1996. British Film Policy. In Film Policy: International, National and Regional Perspectives. Edited by Albert Moran. London: Routledge, pp. 101-13.

Katsiaficas, George. 1987. The Imagination of the New Left. A Global Analysis of 1968. Boston: South End Press.

Kellner, Douglas. 1993. Film, Politics, and the Ideology. Toward a Multiperspectival Film Theory. In Movies and Politics. The Dynamic Relationship. Edited by James Combs. New York: Garland Publishing, pp. 55-92.

Kelman, Peter G. 2001. Protesting the National Identity: The Cultures of Protest in 1960s Japan. Ph.D. thesis, University of Sidney, Sidney, Australia, January.

Kersten, Rikki. 2009. The Intellectual Culture of Postwar Japan and the 1968-1969 University of Tokyo Struggles: Repositioning the Self in Postwar Thought. Social Science Japan Journal 12: 227-45. [CrossRef]

Ko, Mika. 2010. Japanese Cinema and Otherness. Nationalism, Multiculturalism and the Problem of Japaneseness. London: Routledge.

McDonald, Keiko. 1983. Cinema East. A Critical Study of Major Japanese Films. Teaneck: Fairleigh Dickinson University Press.

Murakami, Fuminobu. 2005. Postmodern, Feminist and Postcolonial Currents in Contemporary Japanese Culture. A Reading of Murakami Haruki, Yoshimoto Banana, Yoshimoto Takaaki and Karatani Kojin. London and New York: Routledge.

Needham, Gary. 2006. Japanese Cinema and Orientalism. In Asian Cinemas. A Reader \& Guide. Edited by Dimitris Eleftheriotis and Gary Needham. Edinburgh: Edinburgh University Press, pp. 8-16.

Noonan, Patrick J. 2012. "Our Dissolution": Subjectivity, Collectivity, and the Politics of Form in 1960s Japan. Ph.D. thesis, University of California, Oakland, CA, USA.

Raine, Michael J. 2002. Youth, Body, and Subjectivity in the Japanese Cinema, 1955-60. Ph.D. thesis, The University of Iowa, Iowa City, IA, USA, May.

Ramlochand, John. 2006. Japanese Cinema: Time, Space, Nation. Ph.D. thesis, McGill University, Montréal, QC, Canada, May.

Standish, Isolde. 2011. Politics, Porn and Protest. Japanese Avant-Garde Cinema in the 1960s and 1970s. New York: The Continuum International Publishing Group.

Tsurumi, Kazuko. 1975. Student Movements in 1960 and 1969. Continuity and Change. In Postwar Trends in Japan. Edited by Shunichi Takayanagi and Kimitada Miwa. Tokyo: University of Tokyo Press, pp. 195-227.

Yang, Manuel. 2008. Yoshimoto Taka'aki's Karl Marx: Translation and Commentary. Ph.D. thesis, University of Toledo, Toledo, $\mathrm{OH}$, USA, August.

Yasko, Guy T. 1997. The Japanese Student Movement 1968-70: The Zenkyoto Uprising. Ph.D. thesis, Cornell University, Ithaca, NY, USA, August.

Yomota, Inuhiko. 2010. The Genealogy of the Mother. Eros plus Massacre. In Yoshida Kijū: 50 Years of Avant-Garde Filmaking in Postwar Japan. Edited by Dick Stegewerns. Oslo: Norwegian Film Institute, pp. 42-51. First published 2004. 
Yoshida, Kijū. 2010. My Film Theory. The Logic of Self-Negation. In Yoshida Kijū: 50 Years of Avant-Garde Filmaking in Postwar Japan. Edited by Dick Stegewerns. Oslo: Norwegian Film Institute, pp. 15-18. First published 1969. Žižek, Slavoj. 1994. Mapping Ideology. London and New York: Verso.

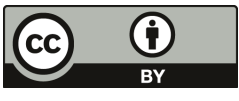

(C) 2018 by the author. Licensee MDPI, Basel, Switzerland. This article is an open access article distributed under the terms and conditions of the Creative Commons Attribution (CC BY) license (http:/ / creativecommons.org/licenses/by/4.0/). 


\title{
Article \\ Gendering the Japanese Empire: Ri Kōran as 'Transnational' Star?
}

\author{
Griseldis Kirsch \\ Department of East Asian Languages and Cultures, SOAS University of London, London WC1H 0XG, UK; \\ gk10@soas.ac.uk
}

Received: 10 October 2019; Accepted: 19 November 2019; Published: 21 November 2019

\begin{abstract}
This paper aims to assess how Ri Kōran came to represent the gender dichotomies of the Japanese Empire. Looking at two propaganda films, Suzhou Nights (1941) and Sayon's Bell (1943), I will work out how the roles she played are indicative of the gender roles in the Japanese Empire, taking into account her transnational star persona.
\end{abstract}

Keywords: Ri Koran; Li Xianglan; Yamaguchi Yoshiko; transnationality; Japanese Empire; propaganda films

\section{Introduction}

Ri Kōran ${ }^{1}$ was the Chinese stage name of the Japanese actress Yoshiko Yamaguchi. She was born in 1920 in Manchuria to Japanese settlers and had grown up between Japan and China. Her Chinese name comes from her 'adoption' into the family of a friend of her father's, as is custom among close friends in China (Yamaguchi and Fujiwara 1987, 2015). ${ }^{2}$ Not only did her background and upbringing lead to her being fluent in Chinese, but, having attended a Chinese girls' school, she was also culturally versed enough to blend in with other Chinese. She was able to traverse boundaries between China, Japan and Manchuria and their languages and cultures. What makes her story special in comparison to many other Japanese in Manchuria in a similar situation at the same time, is that her 'difference' was publicly exploited for the sake of the Japanese Empire and she became one of the most visible stars of its propaganda machine, playing not just Chinese characters, but also Russian, Mongolian and Korean colonial subjects (Baskett 2008). As Chia-Ning Chang points out in the introduction to his translation of Yamaguchi's autobiography, while other such stars have faded away, "[ ... ] Li/Yamaguchi still seems to retain a peculiar allure to audiences in China, Japan, Hong Kong, and Southeast Asia" (Chang 2015, Kindle loc. 229). However, this "allure" is insolubly tied to her gender and the gender politics of the time; posing as a Chinese woman, her characters were trapped in an inferior position to her male, Japanese, counterparts. In that sense, as stars are symbols of something else and, as such, connoted to certain attitudes and desires (Dyer 1998), the creation of the star persona of 'Ri Kōran' embodies the hierarchies of the Japanese Empire. Baskett supports this notion, "In her many incarnations, Ri Koran was a powerful tool of propaganda that brought disturbing new life to Japanese Pan-Asianist slogans, for in no uncertain terms she promised the fulfillment of the catchphrase 'Asia is one'" (Baskett 2008, p. 78).

Although she herself claims never to have kept her Japanese nationality secret (Yamaguchi and Fujiwara 1987, 2015), she did little to clarify it either (Tamura 2007). That she was not ethnically Chinese

1 The Chinese reading of her name is Li Xianglan. Ri Kōran is the Japanese reading of the same characters. Throughout the Sinophone world, she is known by the Chinese reading only. Although, in congruence with the rest of the volume, Japanese names are given in Western order, Ri Köran/Li Xianglan will continue to follow the Japanese and Chinese convention, with the family name first, as this is how she is commonly known.

2 The author of the article would like to thank the various anonymous reviewers for their invaluable feedback. 
was not public knowledge at the time. As Stephenson writes, Ri was often carefully kept apart from her fans, so as to not destroy the myths surrounding her star persona, leaving only her "traces" to be found everywhere (Stephenson 1999). This illusion of Ri Kōran could therefore hold many identities and none, gaining life according to the desires of the audience. As Chang (Kindle loc. 444-454) asserts, it was essential to maintain this appearance, "So long as the vague suspicions about Yamaguchi's true ethnic origin did not erupt into a national scandal or an international firestorm, the enhanced murkiness of Yamaguchi's identity served only to accentuate her personal mystique and her legend as a transnational star" (Baskett 2008). However, her transnational stardom is tied to the experience of Japanese imperialism across Asia and predominantly signifies Japanese imperialism above anything else. It is important to remember, in this context, that filmmaking was highly regulated in Japan at the time, with strict censorship preventing potentially undesirable messages. Considering that, at the time, media and communication theorists around the world were actively discussing the influence of the mass media and their ability to guide the masses, it comes as no surprise that, already, in 1938, before Ri Kōran's rise to stardom, the Censorship Division of the Home Ministry in Japan issued guidelines as to what films should be shown and, according to High, they included:

(1) celebrations of the 'Japanese spirit' as seen in the family system and of the national spirit of self-sacrifice; (2) use of film to re-educate the masses, especially young people and women, whose Westernization has caused them to reject traditional values; [ .. . ] (4) imbuing respect for fathers and elder brothers; (5) suppression of 'the tendency toward individualism inspired by European and American films'. (High 2003, p. 292)

The media was thus actively used in order to stir national sentiment, particularly as the war dragged on, contributing greatly to what Louise Young terms "war fever" (Young 1998, p. 55). Using the term propaganda in this (Lasswell 1927, p. 627) sense, as a means "to reaffirm or redefine attitudes", as outlined above (Lasswell 1927), films at the time were used to visualize such desirable attitudes, and Ri Kōran's films were no exception.

Therefore, it seems as if Ri Köran's persistence in the history of Japanese film is also tied to her gender, and not just the roles she played and the songs she sung. As the Japanese Empire was indeed strongly gendered, a female star as an embodiment of Japan's colonial subjects correlates perfectly to the politics of the time. As an assessment of her role in Japanese imperial propaganda cannot be made without looking at the films she starred in (not just her star persona), I will do a close reading of two of the films she made in collaboration with the Japanese film studio Shōchiku. The films to be analyzed are Suzhou Nights (Sōshū no yoru, dir. Hiromasa Nomura, Shōchiku 1941) and Sayon's Bell (Sayon no kane, dir. Hiroshi Shimizu, Shōchiku 1943), with emphasis on the latter film, as it has often been overlooked. ${ }^{3}$ Prior to the film analysis, I will briefly introduce how gender politics underpinned the creation of the Japanese Empire. Overall, I will attempt to answer the question to what extent Ri Kōran's status as 'transnational star' correlated with those gender politics.

\section{Gendering the Empire}

The Japanese Empire was based on imagined family ties. Influenced by the Neo-Confucian writings of the Mito School of the late Edo Period, in particular those of Seishisai Aizawa (1782-1863), the state was envisaged along Confucian family ideals (Beasley 1990). Within these ideals, male stands over female, elder over younger, and servitude is demanded towards the more senior members. The national polity (kokutai) at the time mimicked on the macrolevel what was supposedly present on the microlevel. Within Japan, the Emperor was the father of all Japanese, who were all brothers, some more senior than others, turning Japan into a family state. During the colonial expansion,

3 I will disregard its actual success at the box office at the time; however, both films have been released on videotape and DVD, suggesting a more lasting impact than their short-term success (or lack thereof) at the time. Furthermore, both films have been chosen because of the discourses they speak to, rather than their potential success. 
the colonized people also had to be included in this polity, and, often, this meant that they had to undertake compulsory emperor worship and follow Shinto rites (ibid.). Furthermore, incorporating them into the national polity of the family state meant turning them into younger siblings of the male-connoted Japanese state, thus giving Japan the superior position of elder male to whom all need to answer.

The notion of the Greater East Asia Co-Prosperity Sphere, which was announced for the first time in August 1940 by the then foreign Minister Yōsuke Matsuoka (Beasley 1990), can be seen as the underpinning principle of the Japanese colonial empire. In a sense, the Greater East Asian Co-Prosperity Sphere also spoke to imagined family relations, albeit less overtly. All of Asia was to 'prosper' under Japanese guidance, putting Japan in the superior position. Within this framework, China was often seen as a woman and not given the more powerful position of a younger male. In that worldview, as the historian Aizan Yamaji pointed out in 1917, China may once have been pretty, but was now worn out, like an 'old prostitute' (High 2003). This coding of China as an 'old prostitute' speaks to Young's notion of colonial desire, whereby the Other is sexually loose and has different, more dangerous, moral standards than the colonizer (Young 1995). The colonial Other can present a danger to the colonizer, but at the same time holds a fascination for them. Additionally, not only was China female-connoted and thus, in the Confucian order of society, inferior, Japan also saw China as its own Orient, as a vision of its own past from which it had evolved (Tanaka 1993). It therefore put itself in a similar position to the one the Western imperialist powers saw themselves in, as civilized and civilizer. Accordingly, records of the time saw China perennially as inferior, less developed and dirty, fostering a sense of superiority in the Japanese (ibid.). Like any other imperial power, Japan used its mission civilisatrice as an excuse for its military exploits, and the stereotypes and preconceptions of China as inferior became prevalent among the Japanese. Even Yoshiko Yamaguchi herself speaks of having been verbally abused as 'Chinese' during her visits to Japan, mainly because she spoke both languages fluently (Yamaguchi and Fujiwara 1987, 2015) and thus could not be placed clearly into the ethnical hierarchies of the time. ${ }^{4}$

It is against this backdrop that both Ri Kōran's films and her career must be seen. Therefore, a Japanese woman, particularly one as young as Yamaguchi (she was, after all, merely eighteen years old when she commenced her career), was ideal for the male Japanese producers, as the reservations that any Chinese national may have had, did not need to be overcome. ${ }^{5}$ In a studio system that did not usually grant a voice to actors, Yamaguchi would have been the last person to have been given a choice of scripts, nor was she in control of her own star persona. Ri Kōran thus remains a signifier that has been filled with life in the male-dominated Japanese sphere of influence.

\section{Gender in Suzhou Nights and Sayon's Bell}

The films that catapulted Ri Kōran to stardom were produced by the Manchurian film company Man'ei. Man'ei, was a joint venture between the photographic unit of the Manchurian Railway Company and the Manchurian government. While Japanese censorship may not have applied in the same way, Man'ei was set up in an attempt to promote the principle of the Manchurian state, gozoku kyōwa (Harmony of the Five Races), and, thereby, the 'benefits' of a Japanese presence on the Asian continent to a wider audience. Yoshiko Yamaguchi, as Ri Kōran, was ideal for that purpose, given that her transnational background already embodied that principle. Or, as Chang puts it, "she came to represent a meticulously handcrafted cultural construct programmed to help materialize the subordination, or at least the acquiescence, of those living under Japanese military or de facto control" (Chang 2015, Kindle loc. 285).

4 Discrimination notwithstanding, Ri Kōran also had a devout fan following in Japan, with people almost rioting to get tickets for her concerts (Stephenson 1999).

5 Baskett speaks of the refusal of experienced Chinese actors to collaborate with the Japanese for fear of being branded as traitors (Baskett 2008) 
Ri Kōran joined Man'ei in 1938 and, in her autobiography, she makes it sound like it was a decision made over her head, stumbling into her career rather than actively pursuing it (Yamaguchi and Fujiwara 1987, 2015). While the first films she made with Man'ei cannot necessarily be called blatant propaganda films, the continental trilogy she subsequently shot with Kazuo Hasegawa as her co-star and in collaboration with the Japanese studio Tōhō were much more so. In each of the three films, Song of the White Orchid (Byakuran no uta, dir. Kunio Watanabe, 1939), China Nights (Shina no yoru, dir. by Osamu Fushimizu, 1940), and Vow in the Desert (Nessa no chikai, dir. Kunio Watanabe, 1940), Ri Kōran was cast as Chinese women who harbour reservations against the Japanese. Employing motifs reminiscent of William Shakespeare's The Taming of the Shrew, all of her characters do, after some misunderstandings and with a good effort on the side of the Japanese, see 'reason' (i.e., fall in love with the Japanese man), making a less hostile encounter possible not just for the couple, but also, more symbolically, for a Sino-Japanese 'friendship' (Baskett 2008; Chang 2015; High 2003). Yamaguchi herself states, "All the films in the continental trilogy were mundane melodramas; moreover, they were also propaganda tools in the service of Japan's continental policy" (Yamaguchi and Fujiwara 2015, Kindle loc. 2857).

Although Suzhou Nights (Sōshū no yoru, 1941) is not part of the continental trilogy, and was made by Tōhō's competitor Shōchiku, its plot is very similar and seems to have been intended to cash in on the success of its predecessors. However, it has not received as much attention as the continental trilogy, even though it is as overtly propagandistic as the others. ${ }^{6}$ Ri Kōran plays Meilan, a young woman who works in an orphanage in Shanghai, where a lot of children live who have been displaced by the war. She is rude and hot-headed, insulting the Japanese at every possible instant, hating them for having brought misery upon the Chinese. Her Japanese co-star is Shüji Sano, who plays a Japanese doctor named Kanō. Kanō selflessly saves a Chinese child in Meilan's care twice from certain death. Through his kindness and bravery, he earns Meilan's respect. Like the films in the continental trilogy, Suzhou Nights is a story of a taming of the shrew, and again the 'shrew' will fall in love with the Japanese man. Suzhou Nights differs from the other films, because there is no happy ending for their love story. Meilan is betrothed to a childhood friend. As she unhappily looks to the future, Kanō leaves Shanghai to go further into China.

This film is symbolic on several levels. Not only does Kanō go deeper into China, thus symbolizing and justifying the continuing invasion of China, but Meilan and Kanō again represent a stubborn China and a benevolent Japan. Meilan needs to be brought to reason and accept Japanese (male) dominance. Thus, the same gender tropes apply as in the continental trilogy. Once she has been convinced, Kanō is free to go, to convince other Chinese of the true intentions of the Japanese. Tellingly, the Japanese are all represented by men, and most of them are doctors, not soldiers, thereby clearly fulfilling a humanistic mission in China (and on screen). By contrast, most Chinese characters are either female or children and therefore, under Neo-Confucian ideals, more easily dominated. The one Chinese man of note, Meilan's future husband, is a criminal, as he unsuccessfully tries to murder Kanō. In another act of selflessness, Kanō forgives him, turning even an attempt on his life into a misunderstanding that merely needs to be overcome by benevolence. Yet, Meilan's initial hatred is not shown as being entirely unfounded, as the film does refer to the war that is raging in China-after all, some of the children are war orphans. Meilan's change of heart is thus symbolic in the context of the Japanese expansion in China. The propagandistic message of the film thus seems to be that, if all Chinese just acknowledged the true civilizing mission of the Japanese, the war would not be necessary.

The other Shōchiku film, Sayon's Bell (Sayon no kane, 1943) takes a different approach to convey its imperialistic message. Unlike Suzhou Nights, there is no love story at the heart of the film, and it is not so much about getting the colonial subjects to accept the dominance of the Japanese, but to show how they have already accepted it. Yomota asserts that Sayon's Bell belongs to the "films based on the

6 For a discussion of this film, see also (Kirsch 2015). 
kōminka seisaku (measures to turn the colonized people into imperial subjects)" (Yomota 2001a, p. 9, italics, translation and insertion mine). Hong supports that notion, and, furthermore, elucidates the history of the film: Sayon's Bell is based on a true story. However, that does not necessarily mean that the story of the film itself is true (Hong 2004). In 1938, a young aboriginal girl named Sayon fell into a river and vanished. This simple news item may, in itself, not necessarily seem noteworthy, were it not for the fact that it developed a life of its own and became akin to an 'urban myth' in colonial Taiwan. The various manifestations of the story that subsequently followed turned the unfortunate girl into a heroine, who died while protecting a Japanese flag (ibid.). The story became so popular that a film version of it was merely a logical conclusion, and it was described as a "heart-warming story of barbarians" intermingled with a "story of patriotism" (Nihon eiga nenkan 1943, cited from Hong 2004, p. 193, translation mine). Hence, the film shows the Taiwanese not just as obedient imperial subjects, but also as exotic people living in paradise (Hong 2004), who are, nonetheless, nothing but barbarians compared to the superior Japanese. ${ }^{7}$ In the opening sequence, which is eight minutes and twenty seconds long, we see Taiwanese aboriginals in their traditional clothing, working diligently for the benefit of the Japanese Empire. The musical score is upbeat, while the captions on screen introduce them as the "Takasago' ${ }^{\prime}$ and describe their efforts for the Japanese Empire. Apart from the Taiwanese aboriginals who volunteered as soldiers, that are shown towards the end of those eight minutes, all of them wear traditional clothing making them visually different to the Japanese. At the same time, this also turns them into exotic, not-so-civilized Others, in line with how the film was promoted. Perhaps unwillingly, the film also shows the contradictions that the propaganda machine of the Japanese Empire was capable of, and that persisted in any colonial Empire. In highlighting the successes of the 'taming of the barbarians' (by letting them speak Japanese and fight for the Empire), they nonetheless need to remain 'exotic barbarians' in order to justify the continued colonisation, turning the Taiwanese into civilized, yet uncivilized at the same time. The exoticism of the opening sequence, and of the film as a whole, is underlined by the promotion material of the time, which has been reproduced in the volume Ri Kōran to higashi ajia (Yomota 2001b). While the monochrome film itself is unable to show the colourfulness of the traditional Taiwanese garb, the promotional material was in colour, enhancing the sense of exoticism where the film technologically failed.

Ri Kōran plays Sayon, the doomed Taiwanese aboriginal girl. While, in all her other films, she portrays a strong-willed woman (who is then nonetheless happy to change her mind when 'prompted'), Sayon is simple, naïve and good-natured. Her greatest goal is to raise as many pigs as possible to provide as much food as possible for the Japanese Army and, therefore, to contribute to the war effort. The film's opening sequence is again significant in that respect, as it also shows the Taiwanese aboriginals fulfilling their duties as Japanese subjects by indeed planting seeds to 'feed the soldiers' and raising the Japanese flag while paying respects to the Emperor. As this film was made in 1943, when victory seemed to become ever more distant, the war effort is represented as joint act, all family members of the Empire pulling together.

Altogether, only a few Japanese characters (mainly the governor of the region and a few soldiers) appear in the film, and the Taiwanese aboriginal men are quasi-Japanized in their place. Everybody speaks Japanese on screen and there are no villains. The Taiwanese characters' fluency in Japanese and the use of Japanese names for the Taiwanese men are in line with colonial policy of the time, although it is an unrealistic representation, as few Taiwanese would have spoken Japanese so eloquently and used Japanese names even among themselves (Hong 2004). Interestingly, only the Taiwanese men have taken Japanese names and are being addressed as such. The women still have Chinese names, which underlines their difference and makes them inferior not only to the Japanese, but also to the male members of their ethnic group. This is also underlined by Sayon's simple nature.

7 That the reality of colonial life in Japan was different goes without saying. Ching (2001) provides a good overview over the 'Japanisation' of Taiwan.

8 Takasago was a catch-all Japanese term to refer to various indigenous ethnic groups in Taiwan. 
Unlike the Chinese, hot-headed girls that had become somewhat like Ri Kōran's trademark in the continental trilogy and Suzhou Nights, Sayon, the Taiwanese aboriginal girl, does not need convincing and harbours no ill-will against her masters. She willingly accepts being dominated by her fellow tribesmen, as well as the Japanese. Sayon seems incapable of any defiance, so the only time that she does defy male advice, it ends in tragedy. When the men in her village volunteer for the war and she wants to send them off, she drowns in a river that a violent storm has turned into a raging stream. She had been warned not to follow them, symbolising that disobedience leads to certain death.

Hong (2004, p. 198) elucidates that Sayon's character represents 'nature', and one could extend that to all female characters on screen, not just Sayon (for whom it is just more evident). All Taiwanese aboriginal women nurture, care, look after the fields and animals and represent, in a sense, nature. By contrast, the Taiwanese men appear 'cultured'. Not only are they more educated and speak Japanese at a higher level than the women, but they have already attained a higher level of cultivation, namely a Japanese name. Only the Japanese men themselves appear even more cultured, as they are the only ones living in solid houses rather than huts and have been tasked with looking after the colonial subjects. The hierarchies that evolve in this film are thus threefold, with the women, particularly the simple Sayon, being at the lower end of the scale. Gender is intertwined with the nature-culture divide (MacCormack 1980), which in turn correlates to the degree of 'Japanization' and the success of the kōminka seisaku. The contradictions of the Japanese Empire, the blurred dichotomies of 'civilized' and 'uncivilized' that run through the film, are also intertwined with gender, as the women, at the lower end of the spectrum, remain 'more barbarian' than the men and in need of guidance (and culture/cultivation). In that sense, the women continue to symbolize the less civilized, more 'natural' Taiwan, whereas the Taiwanese men represent the process of progress.

In all of Ri Kōran's films, gender politics are always tied in with colonial politics. Ri Kōran has been rendered an object of desire by her submissiveness and the male gaze in the films, while keeping enough 'Chineseness' to credibly personify Japan's colonial desire for Asia, without the difficulties of having to conquer it. Her star persona retained the allure of embodying the seemingly successful colonial enterprise, whether she posed as a Taiwanese or Chinese woman. This illusion was carefully maintained, resulting in her being tried as a traitor and collaborator after the end of the war, ${ }^{9}$ based on the films that she had starred in (Yamaguchi and Fujiwara 1987, 2015).

\section{Conclusions}

I, Yamaguchi Yoshiko, a Japanese, was that Li Xianglan — a girl who knew nothing about the world, but still a Chinese entity concocted at the hands of the Japanese, just like Manchukuo. It pains me whenever I think about it.

Yamaguchi and Fujiwara (2015, Kindle loc. 1597)

Ri Kōran and her films remain a symbol of the Japanese Empire and its transnational nature (Baskett 2008; Chang 2015; Washitani 2001). Michael Baskett mentions a collage of five pictures of Ri Kōran, in which she wears all five national garbs of Manchuria (Mongolian, Chinese, Korean, Japanese and Russian), visually personifying the guiding principle of Manchuria, the Harmony of the Five Races (Baskett 2008). However, due to her nationality and gender, but also the way the film industry was structured, she could only ever embody what the Japanese imagined the Empire should be, not what it really was, masking the truth and creating an illusion. She represented the idealized version of the Japanese Empire, not the violent reality of the colonial conquest. Her characters were subservient and easily dominated, created to reassure her Japanese audiences of the colonial enterprise and present them with a justification for the colonial rule in China.

9 After the end of the war, Yamaguchi had to stand trial in China (which was then still being controlled by the Chinese nationalists), accused of collaborating with the Japanese in their propaganda films. She was acquitted, as she could prove her Japanese nationality (Yamaguchi and Fujiwara 1987, 2015). 
Although Ri Kōran did make films for audiences in Manchuria (Tamura 2007), the Chinese were not the only intended audiences for her propaganda films. She was meant to be the model colonial subject for the Japanese, and, by extension, her subservience could have fulfilled the same function for the Chinese. Yet, unlike in the many other propaganda films of the time, in which, as High points out, the Chinese appear as faceless masses, her films stand out, because she gave some depth to the characters she played (High 2003). In spite of the transnational nature of her career and life, the Chinese persona she performed made her Chinese for the feel-good consumption of the Japanese, presenting them with an idealized version of their Empire, how things could be if all Chinese were like Ri Kōran.

Ri Kōran, her brand and career, remain invariably tied to the past. After the war, Yamaguchi tried to reinvent herself as Shirley Yamaguchi in Hollywood and Yoshiko Yamaguchi in Japan, but when she was stripped of her transnational star persona, she never managed to attain the same success as when she posed as Chinese and was Ri Kōran. The illusion that had surrounded her was too strong; Ri Kōran was a diva, a creation of the golden age of film and could not be replicated or reinvented. Nonetheless, Yoshiko Yamaguchi's whole life, not just her career, remained intertwined with the Japanese Empire. She was born in Manchuria, spent most of her youth in China and only migrated to Japan after the war. When her career as an actress ended, Yoshiko Yamaguchi became a politician in the Upper House of the Japanese Parliament, where she remained outspoken on the necessity for the Japanese to atone for Japan's imperial exploits. Her life came to full circle when she became head of the Asian Women's Fund, a fund set up to compensate former comfort women of the Japanese Imperial Army. Just as Ri Kōran/Yoshiko Yamaguchi remained an embodiment of Japan's imperial past, the Japanese Empire continues to cast a shadow deep into post-war Japan. Japan's images of China are equally still clouded by colonial imaginary (Kirsch 2015), seemingly never releasing the two countries from their shared past.

Funding: This research received no external funding.

Conflicts of Interest: The author declares no conflict of interest.

\section{References}

Baskett, Michael. 2008. The Attractive Empire: Transnational Film Culture in Imperial Japan. Honolulu: Hawai'i University Press. ISBN 978-0-8248-6460-6.

Beasley, William G. 1990. The Rise of Modern Japan. London: Weidenfeld and Nicholson. ISBN 0-297-79720-4.

Chang, Chia-Ning. 2015. Introduction-Yamaguchi Yoshiko in Wartime East Asia: Transnational Stardom and Its Predicaments. In Fragrant Orchid: The Story of My Early Life. Translated by Chia-Ning Chang and Amazon Kindle. Honolulu: University of Hawai'i Press, pp. 185-967. ISBN 978-0-8248-5402-7.

Ching, Leo T. S. 2001. Becoming "Japanese": Colonial Taiwan and the Politics of Identity Formation. Berkeley: University of California Press. ISBN 0-520-22551-1.

Dyer, Richard. 1998. Stars. Paperback Edition. London: British Film Institute. ISBN 0-8517-0643-6.

High, Peter B. 2003. The Imperial Screen: Japanese Film Culture in the Fifteen Years' War, 1931-1945. Paperback Edition. Madison: University of Wisconsin Press. ISBN 978-0-2991-8134-5.

Hong, Yawen. 2004. Senjika no Taiwan eiga to 'Sayon no kane'. In Eiga to 'Daitōakyoeiken'. Edited by Kenji Iwamoto. Tokyo: Rinwasha, pp. 181-205. ISBN 4-91608745-3.

Kirsch, Griseldis. 2015. Contemporary Sino-Japanese Relations on Screen: A History, 1989-2005. London: Bloomsbury Academic. ISBN 978-1-4725-7238-7.

Lasswell, Harold D. 1927. The Theory of Political Propaganda. The American Political Science Review 21: 627-31. [CrossRef]

MacCormack, Carol P. 1980. Nature, Culture and Gender: A Critique. In Nature, Culture and Gender. Edited by Carol P. MacCormack and Marilyn Strathern. Cambridge: Cambridge University Press, pp. 1-24. ISBN 0-521-28001-x.

Stephenson, Shelley. 1999. Her Traces are Found Everywhere: Shanghai, Li Xianglan, and the 'Greater East Asian Film Sphere'. In Cinema and Urban Culture in Shanghai, 1922-1943. Edited by Yingjin Zhang. Stanford: Stanford University Press, pp. 222-45. 
Tamura, Shizue. 2007. Ri Kōran no Koibito: Kinema to Sensō. Tokyo: Chikuma Shobō. ISBN 978-4-480-87355-2.

Tanaka, Stefan. 1993. Japan's Orient: Rendering Pasts into History. Berkeley: University of California Press. ISBN 978-0-520-07731-7.

Washitani, Hana. 2001. Ri Kōran, Nichigeki ni arawaru: Utau Daitōakyōeiken. In Ri Kōran to Higashi Ajia. Edited by Inuhiko Yomota. Tokyo: Tōkyō daigaku shuppankai, pp. 21-56. ISBN 4-13-080094-9.

Yamaguchi, Yoshiko, and Sakuya Fujiwara. 1987. Ri Kōran: Watakushi no Hansei. Tokyo: Shinchōsha. ISBN 4-103-66701-x.

Yamaguchi, Yoshiko, and Sakuya Fujiwara. 2015. Fragrant Orchid: The Story of My Early Life. Translated by Chia-Ning Chang and Amazon Kindle. Honolulu: University of Hawai'i Press. ISBN 978-0-8248-5402-7.

Yomota, Inuhiko. 2001a. Kuchie kaisetsu. In Ri Kōran to Higashi Ajia. Edited by Inuhiko Yomota. Tokyo: Tōkyō daigaku shuppankai, pp. 9-10. ISBN 4-13-080094-9.

Yomota, Iinuhiko, ed. 2001b. Ri Kōran to Higashi Ajia. Tokyo: Tōkyō daigaku shuppankai. ISBN 4-13-080094-9.

Young, Robert J. C. 1995. Colonial Desire: Hybridity in Theory, Culture and Race. London: Routledge. ISBN 978-0-4150-5374-7.

Young, Louise. 1998. Japan's Total Empire: Manchuria and the Culture of Wartime Imperialism. Berkeley and Los Angeles: University of California Press. ISBN 0-520-21934-1.

(C) 2019 by the author. Licensee MDPI, Basel, Switzerland. This article is an open access article distributed under the terms and conditions of the Creative Commons Attribution (CC BY) license (http://creativecommons.org/licenses/by/4.0/). 
Article

\title{
Metamorphosis as Origin-Koji Yamamura's Short Animation Franz Kafka's A Country Doctor
}

\author{
Kentaro Kawashima \\ Faculty of Letters, Keio University, 2-15-45 Mita, Minato-ku, Tokyo 108-8345, Japan; kkentaro@flet.keio.ac.jp \\ Received: 5 March 2019; Accepted: 17 April 2019; Published: 22 April 2019
}

\begin{abstract}
In the beginning was metamorphosis. This paradoxical thought, which the ancient Roman poet Ovidius and modern author Franz Kafka represented in their literary works, is visualized in Koji Yamamura's short animation Franz Kafka's A Country Doctor. Diverse metamorphoses that do and do not appear in the Kafka original are so elaborately and dynamically depicted in this animation that no live-action film could possibly represent them. In addition, the film itself can be seen as a metamorphosis, as it is an animation converted from a short story. Such a dominance of metamorphosis is also true for the transculturality and transnationalism of Yamamura's animation. In a sense, the film results from a cultural integration of foreign language and image. However, this integration is also part of the swirl of metamorphosis. The traditional performance art Kyogen, which the director uses to voice the main characters in the animation, could not integrate foreign culture without its own diversification. Yamamura's animation demonstrates that transculturality is another name for fundamental metamorphosis in which diversification and integration occur simultaneously.
\end{abstract}

Keywords: metamorphosis; animation; Franz Kafka; transculturality

\section{Introduction}

In the beginning was metamorphosis. This does not mean that there was first something, and then it metamorphosed. Rather, the origin was metamorphosis. The concept of metamorphosis as origin that I propose in this article refers to Jacques Derrida's criticism on the European tradition of metaphysics in which the origin is considered to be pure unity. ${ }^{1}$ I propose this paradoxical view of metamorphosis as origin because it seems to be useful in describing Koji Yamamura's short animation Franz Kafka's A Country Doctor (2007) as transnational cinema. In "Limiting Imagination of National Cinema", Andrew Higson called into question the paradigm of national cinema, pointing out that national identity and tradition are never "pure or stable" (Higson 2000, p. 67). He continued:

On the contrary, the degree of cultural cross-breeding and interpenetration, not only across borders but also within them, suggests that modern cultural formations are invariably hybrid and impure. They constantly mix together different 'indigeneties' and are thus always re-fashioning themselves, as opposed to exhibiting an already fully formed identity. (Higson 2000, p. 67)

What I want to show in this article is that Higson's observations on the hybridity and impureness of modern cultural formations are exactly true of Yamamura's transnational animation. The concept of metamorphosis as origin fits this purpose perfectly because it underlines the existence of radical difference in the very beginning.

1 Derrida demonstrates in Dissemination (Derrida 1981), for instance, that there is not a pure identity in the beginning, that difference is already at work in the origin. 
The transnationalism of this Japanese animation is quite obvious: As its title shows, this 21-min long work is an adaptation of Franz Kafka's short story A Country Doctor, which was written in 1917 and included in a short story collection of the same title. ${ }^{2}$ Yamamura, an animator and short film producer ${ }^{3}$ whose experimental animations have received critical acclaim at international film festivals, ${ }^{4}$ adapted the narrative of the renowned early 20th-century Prague author who is especially well known for his novella, The Metamorphosis. Published in 1915, The Metamorphosis tells the story of Gregor Samsa's abrupt transformation into a grotesque unknown insect and his inability to return to his original form of a human being. The radical metamorphoses Kafka depicts are not merely unaccountable, they are irreversible. No one can control these changes and their resulting differences, so that all kinds of identities are destroyed. Irreversibility and uncontrollability are the principles of metamorphosis as origin, and as soon as one adopts this viewpoint, nothing in the world can remain the same. This means that there is only an endless dynamic process of metamorphosis.

The concept of "Becoming-Intense, Becoming-Animal, Becoming-Imperceptible" that Deleuze and Guattari write about in A Thousand Plateaus (Deleuze and Guattari 2004) can be seen as a postmodern version of metamorphosis as origin. "Becoming" is neither continuous development nor rational progress, but transformation as uncontrollable movement of difference. This "becoming", in other words, is contrary to the dialectical process described in Hegel's Phenomenology of Spirit, which overcomes differences through synthesis to achieve the identity of spirit in absolute knowledge. This thinking is far from specific to literature and philosophy in the 20th century, however; it can be found in ancient philosophy and literature as well. Friedrich Nietzsche, who speaks about "the innocence of becoming" (Nietzsche 1999b, p. 237), in later works, ${ }^{5}$ finds his own pioneer in the pre-Socratic philosophy of Heraclitus, for whom everything flows (Panta rhei) and the being is only "an empty fiction" (Nietzsche 1999a, p. 75). Another example is the Metamorphoses, a narrative poem by the ancient Roman poet Ovidius Naso. This literary work is the most representative of the aesthetic concept that regards metamorphosis as origin. ${ }^{6}$

\section{Diverse Metamorphoses in the Animation}

Yamamura's transnational animation draws on the aesthetic and ontology of radical metamorphosis in the European tradition. That is already clear in the opening sequence of Franz Kafka's A Country Doctor, in which the main character stands in a snowstorm at night. The country doctor in this scene is not an autonomous actor who can decide his own fate. He is a hopeless despairing subject whom nobody in the village helps, confronted with extremely bad weather and unable to reach a patient in a neighboring village because his horse is dead (Figure 1).

2 Besides Yamamura's animation, there are two German live-action adaptations of The Country Doctor: Cyril Tuschi's Nachtland (1995), 22 min, and Tobias Frühmorgen's Menschenkörper (2004), 17 min (Engel and Auerochs 2010, p. 237). For a discussion of the relationship between Kafka and cinema, see Bilderman and Lewit (2016).

3 For details of Yamamura's biography, see the official homepage: http://www.yamamura-animation.jp/e-prof.html (accessed on 15 September 2018)

4 His animation Mt. Head (2002) won the 2003 Grand Prize at the Annecy International Animation Film Festival. Franz Kafka's The Country Doctor won the 2007 Grand Prize at the Ottawa International Animation Festival.

5 For details of this concept, see the entry "Unschuld des Werdens" (Skirl 2011) in Nietzsche-Handbuch.

6 The Last World (1988) by Austrian novelist Christoph Ransmayr is a wonderful example of post-modern literature that inherits the aesthetic tradition of The Metamorphosis. 


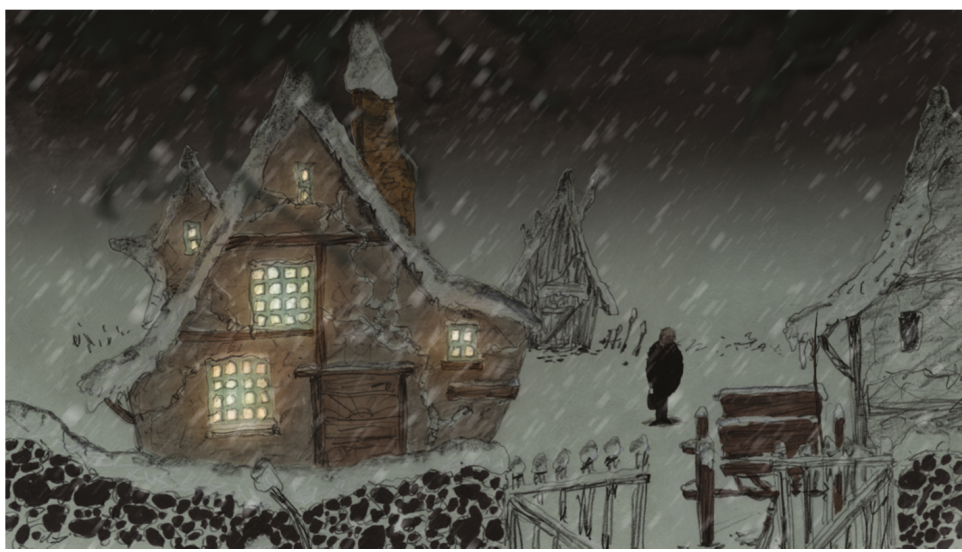

Figure 1. CYAMAMURA Animation/SHOCHIKU.

Exposed to the blizzard, the doctor stands alone in front of his house, like a small plant blown by the wind. Not for even for a moment does his body remain in a stable form. It is completely passive; it grows in an instant and sways violently, warped and deformed by the strong wind in a way that no live-action film could represent.

Only an animation independent of real-world principles could display such a drastically metamorphosing body. Thus, it is not surprising that Paul Wells, a specialist in media studies, writes in his book Understanding Animation that metamorphosis is "the constituent core of animation itself" (Wells 1998, p. 69). Japan studies scholar Susan J. Napier analyzes many patterns of metamorphosis in her book Anime from Akira to Howl's Moving Castle and notes that "animation can and does emphasize transformation in a way that simply no other artistic genre is capable of doing" (Napier 2005, p. 36). Napier deals with contemporary mainstream Japanese animation, not the kind of experimental animation that Yamamura produces. However, her work and that of Wells show that scholars agree that metamorphosis is a common motif in animated films. In this sense, Yamamura's avant-garde animation shares a core characteristic with mainstream Japanese animation.

The country doctor's metamorphosis into a helpless, passive, plant-like being in the opening scene is not an isolated event in the film. It is followed by multiple other metamorphoses. From the viewpoint of Yamamura, as for Kafka, metamorphosis occurs not in isolation but in succession. That is to say, it is neither ideas nor materials that are continuous in the world-it is transformations. For example, in the story of the country doctor, the metamorphosis of a human being into an animal is illustrated by the groom, who not only appears from an unused pigsty, but who also crawls out "on all fours" (Kafka 1988, p. 220). Yamamura faithfully reproduces this description of "becoming-animal". The groom as a bastard of human and animal plays an important role in the story because he pulls two horses out of the pigsty so that the country doctor can start for the neighboring village where his patient awaits. His bestiality is most obvious when he bites Rose, the country doctor's maid, on the face. In the original, Kafka describes this scene as follows:

Yet hardly was she beside him when the groom clipped hold of her and pushed his face against hers. She screamed and fled back to me; on her cheek stood out in red the marks of two rows of teeth. "You brute," I yelled in fury, "do you want a whipping?" (Kafka 1988, p. 221)

The groom appears as a "brute" whose uncontrolled desire the doctor will domesticate with a "whipping". He is not a human being to such a civilized man as the doctor, but an animal that must be tamed. Although the doctor thinks he should stay in his home to protect Rose, the groom starts 
up the carriage against the doctor's will because he wants to be alone with the maid. The bestial groom's active desire contrasts in a dynamic way with the passive, plant-like doctor at the mercy of the snowstorm. Yamamura's animation elaborately depicts this relationship, which is open to multiple interpretations.

The animalizing of the groom corresponds to a different type of metamorphosis, an anthropomorphosis of animals, in the story of the country doctor. When the doctor's carriage arrives at the village and the doctor sees the sick boy in bed, the two horses that had pulled his carriage poke their heads through the windows. Kafka describes this sight as follows:

These horses, now, they had somehow slipped the reins loose, pushed the windows open from outside, I did not know how; each of them had stuck a head in at a window and, quite unmoved by the startled cries of the family, stood eyeing the patient. (Kafka 1988, p. 251)

The horses "eye" the patient, as if participating in the medical examination. Such an anthropomorphosis of the horses is a striking type of metamorphosis which also appears in The New Advocate, the first narrative in the collection of short stories A Country Doctor. In this story, Dr. Bucephalus was once a horse of Alexander the Great but turned into an advocate who represents others in a court of law. "[F]ree and far from the clamor of battle" (Kafka 1988, p. 415), he can now concentrate on reading law books. Another example of anthropomorphosis of an animal found in Kafka is Red Peter, an ape in A Report to an Academy who can speak about his knowledge of human behavior and language. Kafka's narrative world is full of metamorphoses. The two main types, the animalizing of a human being and the anthropomorphosis of an animal, together form a swirl of transformations that deny creatures any solid identity in the post-Darwin age.

Drastic metamorphoses like those mentioned above cross the anthropological boundary between human being and animal. Kafka's world of radical metamorphoses contains a critique on traditional European anthropology. The circulating movement between animalizing of a human being and anthropomorphosis of an animal challenges the "anthropological machine" (Agamben 2004, pp. 33-38) of European philosophy, which defines the human being on the basis of the distinction between human and animal. The country doctor's involvement in the swirl of metamorphoses is strikingly represented in the animation when the doctor thinks of his own death. Kafka's corresponding text reads: "I had still to see that Rose was all right, and then the boy might have his way and I wanted to die too. What was I doing there in that endless winter!" (Kafka 1988, p. 222).

To reproduce the doctor's inner monologue, Yamamura introduces a series of radical metamorphoses that do not correspond directly with the original: The doctor catches the moon in his hands, the moon metamorphoses into a rope, and the doctor uses the rope to hang himself. The hanging doctor then metamorphoses into a horse swinging with its head in the rope. Yamamura understands the strengths of his medium. He himself notes the fundamental relationship between metamorphosis and animation in his book Welcome to the Animation World [Animeshon no Sekai he Youkoso] (Yamamura 2006). ${ }^{7}$ His animation is full of transformations so radical that no live-action film could possibly represent them. The sequence of the metamorphosing doctor is a typical example.

The film also reproduces other metamorphoses from Kafka's story. In the original, the country doctor undergoes a mild transformation, on top of the radical metamorphoses already depicted, when villagers undress him. How exaggerated the doctor's acrobatic movements are as he is being forcibly undressed in Yamamura's film! The animator creates this dramatic sequence not from a heroic body, but from a passive one. The doctor's resulting nakedness can be interpreted as a loss of the authority inherent in the social status of doctors. His authority continues to disintegrate until he is reduced to returning home naked, through the snow. Yamamura depicts with great care the absurdity and

7 Yamamura cites J. J. Grandville, a 19th-century French caricaturist, as a pioneer of animation who drew metamorphoses before the cinema was invented. He writes that he was greatly influenced by Grandville (Yamamura 2006, pp. 22-25). 
humor of the naked doctor riding his horse along the snowy road. The doctor's skinny, weak body emphasizes his passiveness; he cannot control his own body fluttering and flapping in the blizzard.

Another example of a mild metamorphosis, absurd and funny in nature, is the sick boy's very different responses to the doctor's first and second examinations. At the first examination, the boy pleads, "Doctor, let me die" (Kafka 1988, p. 222), even though the doctor finds nothing wrong with the boy. At the second examination, however, the doctor discovers that the boy is indeed sick. In his side is an open wound where worms are "wriggling from their fastness in the interior of the wound toward the light, with small white heads and many little legs" (Kafka 1988, p. 223). The wound is described in a surreal way, defying any logical explanation. Nobody can explain why the doctor missed this at the first examination. The boy also changes his attitude entirely, asking the doctor, "Will you save me?" (Kafka 1988, p. 224). Kafka's text does not explain why the second examination results in a completely different diagnosis and why the boy suddenly behaves differently, as if he had a split personality. The change in the boy is not as radical a transformation as the animalizing of a human being or the anthropomorphosis of an animal, but it is a metamorphosis of one personality into another. Yamamura probably chose this story because it contains many instances of metamorphosis that he could present visually through his animation.

\section{Metamorphosis and Doubling}

This animated film presents many metamorphoses, including both some that do and some that do not appear in Kafka's original story. Crucially, the film itself can be seen as a metamorphosis as it was created by converting a short story into an animation. ${ }^{8}$ For Yamamura's film, metamorphosis is origin not only because it presents diverse metamorphoses in the story of the country doctor, but because it is a product of dynamic media conversion: From written language to a more high-tech medium that includes moving images and sound. That is, in the film, the aesthetic of metamorphosis is realized not only at the level of content, but also at the level of the medium. In other words, for Yamamura, metamorphosis is not merely a motif; it is also a productive current that forms the film itself. The term "adaptation" by which Yamamura's animation is typically understood hides such metamorphosis as productive movement because it does not emphasize the aspect of change and difference. On the contrary, it implies mediation between different existences. Consequently, calling it an "adaptation" diminishes the dynamic aesthetic of metamorphosis, which characterizes Franz Kafka's A Country Doctor.

Yamamura must surely consider that the media conversion from literature to animation can also be understood as a dynamic process of metamorphosis. The self-reflexivity that characterizes Yamamura's animated film suggests this. However, we must first recognize that Kafka's short story is itself self-reflexive. Hans-Thies Lehmann, for example, noted that the narrative revolves around Kafka's writing itself (Lehmann 1984). The snow in which the doctor can hardly move can be read as a metaphor for white paper, while the carriage ride with uncontrollable horses is a metaphor for writing. The failure of the doctor, who must ride, completely naked, on the snowy road, unable to return to his daily life, suggests the fateful failure of Kafka as a writer who left his manuscripts to his best friend Max Brod with the instruction that they should be destroyed upon his death.

Yamamura transforms Kafka's self-reflexivity in his animation. To understand how he does this, the principle of doubling is significant. First, a self-reflection necessarily contains a moment of doubling, and second, the transformation of Kafka's self-reflexivity in the animation can also be seen as doubling. Yamamura emphasizes doubling as a motif throughout the film. Two horses neigh two times in the story; the doctor examines the boy twice; two naked men, the doctor and the patient, lie down on the same bed; and the main character rides the carriage twice as he goes to and returns from

8 Cf. Jochen Hörisch's media theoretical concept of conversions (Hörisch 2004, pp. 404-23). 
the patient's house. These doublings are also present in Kafka's text. ${ }^{9}$ However, Yamamura adds at least two new doublings, which are crucial to the self-reflexivity in the animation. The first is a pair of little black figures, absent from Kafka's story, which appear in the film to speak the doctor's inner monologue. The doctor's voice is split twice. First is a split between his internal and external voice. But the internal voice is further split between the two black figures, which resemble each other so closely that they appear to be twins (Figure 2).

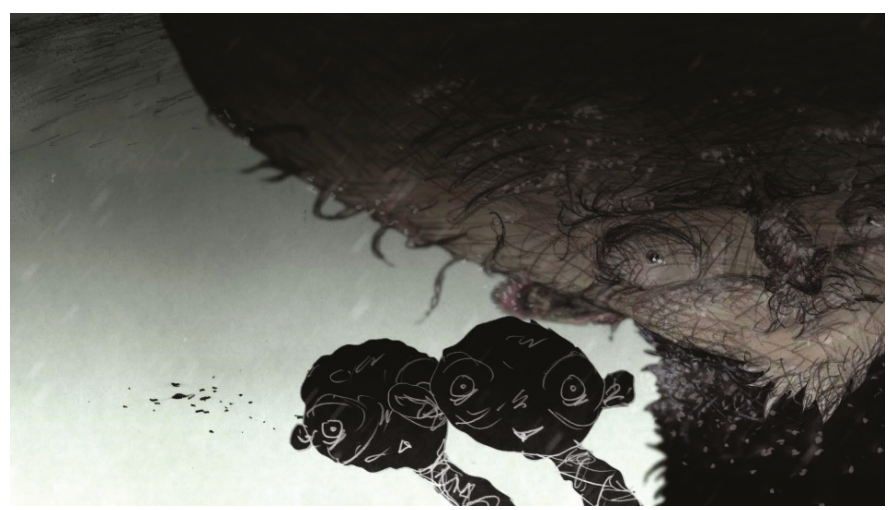

Figure 2. (CYAMAMURA Animation/SHOCHIKU.

The second doubling that Yamamura adds to Kafka's story appears in the last sequence. The viewer momentarily sees two shadows appear from the doctor's house. One shadow is, of course, the doctor's. But whose shadow is the other one? This last shot is noteworthy because it recalls the beginning of the story where the doctor, who had heard the night-bell ringing, opens the door. ${ }^{10}$ If the last sequence is thus connected to the opening of the film, this scene then creates a loop, which can be interpreted as a self-reference. Because of this self-referential structure, we can say that the second shadow is likely the filmmaker's. This last scene with two shadows suggests that the doubling-which encompasses not only many pairs and repetitions throughout the film but also the transformation of Kafka's short story into an animation-represents the beginning and the end of the narrative occurring at the same time. The doubling is never a simple copy but generates productive difference.

What is the relationship between doubling and metamorphosis? First, both appear in the content of Yamamura's animation and Kafka's story. And second, the media conversion from Kafka's literature to Yamamura's animated film can be understood not only as metamorphosis, but also as doubling. Doubling and metamorphosis may not initially seem to be similar, but they are related because they are two modes of difference. Both Yamamura's animation and Kafka's short story develop on the bases of metamorphosis and doubling, two principles that coincide with each other in the sense that they oppose the domination of identity.

\section{Metamorphosis as Diversification and Integration}

Finally, let us relate the above observations and reflections to the topic of transculturality and transnationalism. In Yamamura's film, one aspect that cannot be ignored is that the animation is mainly voiced by Kyogen actors from the Shigeyama family. Kyogen is a traditional form of comic theatre in

9 In his excellent article about Kafka's story, Joseph Vogl (Vogl 2006) argues that the doubling and the repetition that dominate Kafka's world are connected with the comic nature of his literature.

10 Cf. an interview with Yamamura about his animation: http://www.animations-cc.net/body-interview.html (15 September 2018). 
Japan that deals with daily, worldly, and humorous motifs, in contrast to Noh theatre (which Kyogen is often performed with), which focuses on the metaphysical, sublime, and serious. The Shigeyama Kyogen company in Kyoto is famous for its experimental works. In Franz Kafka's A Country Doctor, Shigeyama family actors voice all the principal characters except Rose. ${ }^{11}$ Yamamura's animation thus realizes a notable encounter between Kafka, a representative of modernist European literature, and traditional Japanese performance art. This short film is therefore an interesting case of transculturality, worth closer analysis.

There is no precedent for Yamamura's animation in the history of Japanese film in the sense that no Japanese movie adaptation of Kafka's literature had ever been made until Franz Kafka's A Country Doctor was released in 2007. ${ }^{12}$ This film is thus outside the existing domain of Japanese movie culture, as it deals with Kafka's short story and relates transculturally to the European aesthetic tradition of metamorphosis. Such a transcultural diversification at the level of film is accompanied by an opposite movement at the level of language: There is a dimension of cultural integration in the animation, because it translates Kafka's short story from German into Japanese. This means that Yamamura's transcultural animation, which unquestionably crosses cultural boundaries in terms of character, narrative, and motif, includes a contrary movement of cultural integration in terms of language.

There is another important verbal form of cultural integration in Yamamura's film as well. Kyogen as traditional performance art plays a central role in the media conversion of Kafka's story into Japanese animation. This results not in the usual naturalistic articulation of contemporary Japanese speech but in a theatrical and classical vocalization by the Kyogen actors as the film tells the strange story of the country doctor. In this way, the film surely contains a dimension of cultural integration that domesticates foreignness and reduces distance between cultures.

We must remember, however, that the tradition of Kyogen theatre does not remain the same when it interacts with the European aesthetics of metamorphosis. Kyogen changes irreversibly, swept up in the swirl of metamorphosis, to deal with modern themes from this non-Japanese cultural setting. Yamamura's media conversion from German modern literature to Japanese contemporary animation is accompanied by a diversion of Kyogen theatre from tradition to experiment. The traditional performance art could not integrate foreign culture without undergoing its own diversification. Looked at in this way, the last sequence of Franz Kafka's A Country Doctor can be seen in a new light. Kafka's story ends with the words, "Betrayed! Betrayed! A false alarm on the night bell once answered-it cannot be made good, not ever." (Kafka 1988, p. 225) This passage reveals the anger and anxiety of the naked doctor on the horse, who will probably never be able to return to his home, unlike the ancient hero Odysseus, the prototype of an intellectual in the European tradition. In this endless adventure, which takes place not on the ocean but in snow, the doctor must change irreversibly, losing all of what has heretofore constituted his identity. The ending, with the double curse "Betrayed! Betrayed!", is a curious mixture of comedy and tragedy. But the Kyogen performers may say "Betrayed! Betrayed!" as well, because they must leave their familiar domain to experience a dangerous adventure in their performance for Yamamura's animation.

The transculturality that Yamamura's animation achieves is a complex process; it is neither one-way integration nor one-way diversification, but rather chiastic. Transculturality is another name for a fundamental metamorphosis in which diversification and integration, two contradictory movements, occur simultaneously. Such a complex, chiastic transculturality makes it impossible to regard Yamamura's animated film as anything other than transnational cinema. The relationship between diversification and integration in Yamamura's film could be explained using the anti-psychoanalytical vocabularies of Deleuze and Guattari, who noted that deterritorialization and reterritorialization of desires are two sides of the same coin: "the one is the reverse side of the other" (Deleuze and Félix

11 Sensaku Shigeyama voices the country doctor, Shime Shigeyama the groom, Shigeru Shigeyama and Douji Shigeyama the inner voices of the country doctor, and Ippei Shigeyama the boy.

12 Japanese film director Masao Adachi made Kafka's short story A Hunger Artist into a movie and released it in 2016. 
1984, p. 316). Such paradoxical movement is metamorphosis as origin, which Yamamura's animation brings to life.

Funding: This research received no external funding.

Acknowledgments: I'm deeply grateful to Koji Yamamura for permitting his images to be used.

Conflicts of Interest: The author declares no conflict of interest.

\section{References}

Agamben, Giorgio. 2004. The Open: Man and Animal. Translated by Kevin Attell. California: Stanford University Press.

Bilderman, Shai, and Ido Lewit. 2016. Mediamorphosis: Kafka and the Moving Image. New York: Columbia University Press.

Deleuze, Gilles, and Guattari Félix. 1984. Anti-Oedipus: Capitalism and Schizophrenia. Translated by Robert Hurley, Mark Seem, and Helen R. Lane. Preface by Michel Foucault. London: Athlone.

Deleuze, Gilles, and Félix Guattari. 2004. A Thousand Plateau: Capitalism and Schizophrenia. Translated by Brian Massumi. London and New York: Continuum.

Derrida, Jacques. 1981. Dissemination. Translated by Barbara Johnson. Chicago: University of Chicago Press.

Engel, Manfred, and Bernd Auerochs. 2010. Kafka-Handbuch. Leben-Werk-Wirkung. Stuttgart: J. B. Metzler.

Higson, Andrew. 2000. The Ligiting Inagination of National Cinema. In Cinema and Nation. Edited by Hiort Mette and MacKenzie Scott. London and New York: Routledge, pp. 63-74.

Hörisch, Jochen. 2004. Eine Geschichte der Medien. Vom Urknall zum Internet. Frankfurt am Main: Suhrkampf.

Kafka, Franz. 1988. The Complete Stories. Edited by Nahum N. Glatzer. New York: Schocken Books.

Lehmann, Hans-Thies. 1984. Der buchstäbliche Körper. Zur Selbstinszenierung der Literatur bei Franz Kafka. In Gerhard Kurz (Hg.), Der junge Kafka. Frankfurt am Main: Suhrkamp, pp. 213-41.

Napier, Susan J. 2005. Anime from Akira to Howl's Moving Castle: Experiencing Contemporary Japanese Animation. New York: Palgrave Macmillan.

Nietzsche, Friedrich. 1999a. Götzen-Dämmerung. In Der Fall Wagner. Götzen-Dämmerung. Der Antichrist. Ecce homo. Dionysos-Dithyramben. Nietzsche Contra Wagner. Kritische Studienausgabe. Bd. 6. Hrsg. von Giorgio Colli und Mazzino Montinari. München: Deutscher Taschenbuch Verlag, pp. 55-161.

Nietzsche, Friedrich. 1999b. Nachgelassene Fragmente 1882-1884. Kritische Studienausgabe. Bd. 10. Hrsg. von Giorgio Colli und Mazzino Montinari. München: Deutscher Taschenbuch Verlag.

Skirl, Miguel. 2011. Unschuld des Werdens. In Nietzsche Handbuch. Leben-Werk-Wirkung. Herg. von Henning Ottmann. Stuttgart und Weimar: J. B. Metzler, pp. 348-49.

Vogl, Joseph. 2006. Kafkas Komik. In Kontinent Kafka. Mosse-Lectures an der Humboldt-Universität zu Berlin. Hrsg. von Klaus R. Scherpe und Elisabeth Wagner. Berlin: Verlag 8, pp. 72-87.

Wells, Paul. 1998. Understanding Animation. London and New York: Routledge.

Yamamura, Kōji. 2006. Animeshon No Sekai He Youkoso. Tokyo: Iwanami.

(C) 2019 by the author. Licensee MDPI, Basel, Switzerland. This article is an open access article distributed under the terms and conditions of the Creative Commons Attribution (CC BY) license (http://creativecommons.org/licenses/by/4.0/). 
Article

\title{
Japan in Spain. Japanese Culture through Spanish Eyes in the Film Gisaku
}

\author{
Rosanna Mestre Pérez \\ Department of Theory of Languages and Communication Sciences, University of Valencia, 46010 Valencia, \\ Spain; Rosanna.Mestre@uv.es
}

Received: 7 September 2018; Accepted: 24 November 2018; Published: 28 November 2018

\begin{abstract}
Gisaku (2005), by Baltasar Pedrosa, is a unique Spanish movie that was produced to sell the Spanish country brand to visitors attending the Spanish Pavilion at Expo Aichi 2005. It is a cartoon feature production that builds a fantastic plot combining the Expo's theme, the Spanish institutional objective of showing a good image of the country, and the aim of pleasing the target. This paper focuses on the last issue, more specifically on the narrative and production strategies of transcultural exchange developed to attract the Japanese audience. We analyze the movie from a discursive perspective. It is our hypothesis that Gisaku tries to empathize with its target by constructing a certain representation of the Japanese national culture the features of which come from an imagery of Japan negotiated in both traditional and renewed ways from Spain. It is a hybrid anime that deals with transnational representations of the Japanese national identity.
\end{abstract}

Keywords: cartoon movie; Japan and Spain; transnational imagery

\section{Introduction}

Gisaku is a unique movie for several reasons. The first of these goes back to the origin of the project that emerged in 2003 when the Spanish Government convened, through the Spanish Society of International Exhibitions (hereinafter, SEEI), the first public contest aimed at Spanish film producers on the occasion of the International Exhibition of Aichi 2005, in Japan. The objective of the First Ideas Contest for an audio-visual production of animation (SEEI 2005a) was the making of an audio-visual animation that would present Spain "in an attractive way for the Japanese family audience" (SEEI 2005a, p. 27), within the contents programmed by the Spanish Pavilion. The company Castelao Productions S.A., of the Filmax group, was the winner of the competition. The final cost of the film, paid for with both public and private financing, amounted to four million euros-1,800,000 of which were contributed by SEEI, while Filmax Productions provided the rest of the money (thanks to the company itself, the sale of the movie to the Spanish television network TVE, Spanish Institute of Audio-Visual Arts and Cinematography (ICAA) and the Galician autonomous government Xunta de Galicia). The production took place in the record time of twenty months, compared to the usual forty or fifty. This forced the creative team to plan strictly and shorten the whole production process. Most of this was carried out in Spain, using Spanish equipment, but some parts had to be farmed out to foreign teams. Twenty-one animation studios from countries like China, Japan, Italy or Korea collaborated with consolidated working teams that the Spanish producers had no time to organize. The film was not distributed in the Japanese film market, but was released in Spain and distributed in some Latin American countries and the Baltic Republics. This was due to the more flexible policies against violence in movie content in these markets, according to the producer of Gisaku, Rodríguez (2006).

SEEI established the conditions to which the production destined for the Expo should adhere (SEEI 2003): A cartoon film in three languages (Japanese, Spanish and English) that would accompany a comic-book of the film also entitled Gisaku (Pedrosa 2005). The film should include "a journey 
through the geography and diversity of Spain," have "an enormous educational and formative value for the Japanese family audience," and serve "to deepen the mutual knowledge of the respective countries, discovering the common elements (wider and deeper than what is normally thought) and showing what is clearly ours (virtually unknown) to be especially attractive" (SEEI 2003, p. 2).

The tasks of coordination of the Spanish promotion in the Exhibition were carried out by the Spain Brand platform, constituted in January 2003 by public and private organizations ${ }^{1}$. This platform elaborated an analysis of the existing studies on the image of Spain in the Asia-Pacific area. From them it was inferred (Rodao García 2005; SEEI 2005a; Noya 2002, 2004) in Japan, traits of pre-democratic Spain were attributed to the European country ${ }^{2}$, such as scant technical scientific development, the medieval image of cities, a perception of citizen insecurity, and some important products, such as wine, which were unknown. But other aspects were positively valued, such as the prestige of the Spanish culture and an attraction toward the language. Language and culture aroused great sympathy, perhaps because Spain was perceived as a modern yet antiquated country, Western, but very different from other Western countries. Thus, we see a paradox that seems to be in consonance, according to Noya (2004), with the very combination of modernity and tradition that occurs in current Japanese society, which is Asian, but feels different from the other countries in its environment. These data served to configure the profile of the ideal spectator that Gisaku was addressing. Based on them, a list of ten priority objectives was drawn up to disseminate both an updated image of Spain in 2005, a time when the country was in a continuous phase of economic development and was the eighth largest economy in the world, and a plausible image of Japan. As we try to demonstrate with our analysis, the configuration of Japan and what is Japanese in the film derives in part from these objectives. Our analysis attempts to show that the items that make up Japan and the way these are presented on stage derive in part from these objectives and in part from features easily attributable to Japanese culture. Essentially, they are stereotypes of national images represented by their most basic and recognizable traits. Walter Lippmann (Lippmann 1997) defines stereotypes as simple concepts, more false than true, acquired through others rather than through direct experience and strongly resistant to change, a kind of sub-product. On the other hand, stereotypes are not the most creative option to represent the other, although they might be the safest in some contexts. It should be remembered that stereotypes are used because they work, and this is because they appeal to widely recognizable features that are partly true in many cases (Durand 2004). Indeed, they are true in so many cases that due to them a pattern has been created. Stereotypes do not look for originality, but for recognition and acceptance. This framework was used to construct a good image of Spain in Gisaku (Mestre 2007) and a similar positive portrait of Japan.

With regard to the perspective of our textual analysis, we follow the narratological tradition, one of the most consolidated tools with which to study narrative works since Gérard Genette published Figures III (Genette 1972), later reviewed in Nouveau discours du récit (Genette 1998) and followed by other authors who adapted literary categories for use in film studies (Seymour Chatman; Mieke Bal; André Gaudreault, François Jost). Any narrative discourse is the result of an enunciation or utterance process in which two agents or instances participate: A narrator or enunciator who builds a discourse and a receptor or addressee who reconstructs the text updating its meaning when reading it. The final meaning of the text may match to a greater or lesser extent that initially intended by the author, depending on the closeness of their cultural, ideological and aesthetic codes. Enunciator and addressee are the two main poles around which the six agents of a narrative discourse revolve (Chatman 1978). The most interesting ones for our analysis are the figures of implied author and implied reader, abstract instances built through the prints left by the real author in the discourse during the enunciative process. As Casetti (1986) and Casetti and Chio (1990) assert, the trace can be perceived in the organization

1 This platform was made up of Asociación de Directivos de Comunicación, Foro de Marcas Renombradas Españolas, Instituto Español de Comercio Exterior, and Real Instituto Elcano de Estudios Internacionales y Estratégicos.

2 The current democratic system in Spain has been in force since 1978, after the death of dictator Francisco Franco in 1975. 
of what is shown, that look that institutes all the audio-visual information present in a movie. It is everything that reminds us that images and sounds are not given by themselves, but by someone who gives them to us. As such, "there are no stories without a storytelling instance" (Gaudreault and Jost 2004, p. 45). When we talk about the implied spectator we are not alluding, therefore, to the human spectator who sits in a theatre watching a movie, but to the presupposed audience, designed by a narration. We are referring to an abstract figure, inscribed in the text. At the same time, it is the real spectator who traces the signs left in the text. He or she must interpret the meaning(s) of the film following the signals. These can be more or less obvious. They are subjected to the, conscious and unconscious, decisions made by the real author. How explicit they are in the enunciation is a matter of style. Thus, what the real author claims that he or she wants to say with his or her movie may help to understand it, but our vision as an audience must focus on the text and the marks left inside it. We will search for these marks and the constructed implied Japanese spectator in the movie Gisaku.

At the same time, we will consider the terms in which the image of Japanese national identity is stated in this Spanish production made by Spanish creators for a very specific Japanese audience which is supposed to find a pleasant construction of itself in order to adopt a positive reception attitude to the Spanish national content of the movie. This goal is attained through production, narrative and discursive means in which transcultural exchange plays a key role in many ways. We propose that Gisaku can be understood as being transcultural, as MacDougall (1998, p. 245) points out, in relation to ethnographic films, "in the familiar sense of crossing cultural boundaries-indeed the very term implies an awareness and mediation of the unfamiliar-but they are also transcultural in another sense: That of defying such boundaries". Some of this can be traced in Baltasar Pedrosa's movie even if we classify it as an opportunistic transnationalism case, according to Hjort (2010) terminology, due to the ideological ambivalence of its obviously promotional mission. It might be also regarded as a weak transnational film because of the low transnational profile of its production, distribution, reception, etc., and it also can be considered an unmarked one since the transnational themes are not very explicit (Hjort 2010). Certainly, Gisaku has a rather international dimension that elaborates the concept of national identity in a strong way for both the cultures involved: Spanish and Japanese. But let us point out some of the significant production details that suggest a flexible management of cultural patterns and boundaries. Firstly, the movie has a country brand promotional intention, but it is not advertising: It is a fiction feature film made specifically for this purpose. This trait places the movie in an unconventional, and uncomfortable, terrain because a large amount of promotional content must be diluted in its diegesis without losing its appeal. Secondly, despite its fictional nature, the film market is not the ideal destination for this production. Also, Gisaku is intended for a Japanese target, but not for spectators in commercial or mass release cinemas: Small groups of people attending the limited exhibitions at Expo Aichi were the primary audience. Nonetheless, the film had commercial distribution outside Japan too and there was some economic income from the film market, but it was not expected to be a primary source of funding for the production because the Spanish Government had already strongly supported it. Thirdly, the producers chose a foreign kind of cartoon feature production, anime, due to its target, but the movie attempts to be a sort of hybrid animation production (partly anime, partly Spanish/Western animation) more than a proper or pure anime movie, according to the movie creators. Fourthly, by assuming the exposed position of this no man's land aesthetic decision, Gisaku runs a considerable risk of being misunderstood or rejected, especially among otaku viewers, due to the implicit lack of authenticity. Fifthly, the movie focuses on selling Spain, but has a title that sounds more Japanese than Spanish in a sort of national mutation towards the destination culture.

Moreover, Gisaku also deals with a major transnational challenge on its narrative composition, since Japanese characters and their cultural background are represented by a foreign creative team. As we will justify, that team deals with what is Nipponese in the movie in both traditional and newer ways from a Spanish perspective. It is a film bordering the limits of anime and representing Japanese culture from outside its national boundaries. For this reason, it can be said that Japanese and anime presence in this Spanish movie is more about negotiations and appropriations than about imitations 
and influences, employing the terms Elsaesser (2005) uses to refer to the adherence to a reference model in other cinematographic contexts. From "a text-based approach to national cinema" (Highson 1989, p. 36), we explore the creativity that resituates the increasingly decontextualized images of anime (Denison 2010, 2013) and redefines some cultural and national boundaries. To achieve this goal, we analyze the strategies used in addition to the little details or nuances that make this marketing experiment possible. That is why I approach the movie with a qualitative analysis from a discursive perspective that includes considerations of transnational issues. I look at the story to identify some relevant topics, among which stereotypes play a key role. I also analyze the way in which they are transculturally negotiated through various discursive strategies used in both production and narration. The aim of this paper is to evaluate how Gisaku, a movie born in Spain as a unique case of country brand marketing, deals with one of the national identities involved (the Nipponese one) and enhances cultural transferability.

\section{Japan in Gisaku}

In our opinion, Japanese national identity is constructed in the film Gisaku mainly through two discursive strategies. On the one hand, the film includes long-established elements which are clearly recognized as belonging to Japanese culture, such as the figure of a samurai which is represented in the film by the Yohei character. Samurai are part of traditional Japanese culture and its traditional national image, but are very effective when it comes to signposting this culture on the other hand, Japan is also constructed in a subtler way via Spain, more specifically through the careful selection of features of Spanish culture that can easily connect with the Japanese viewer as it is assumed that, in some way, these features also play a significant role in Japanese referents. An example of this would be the choice of the Jerte Valley and its cherry blossoms as one of the many possible Spanish natural spaces portrayed. The cherry tree is surely more emblematic for Japanese people than for Spaniards because of the special value that its flower has in the Nipponese culture.

The items that put what it is considered Japanese in Gisaku have in principle an institutional origin. They come somehow through the Japanese guidelines established for the International Exhibition in terms of theme and subject areas and come more directly through the recommendations collected in the Spain Brand Manual. They are explicit references that are given to the creative team. However, the specific way of narrativizing them, their conversion into an attractive and acceptable audio-visual narration for the Japanese audience, is the result of a complex work of transcultural exchange. It emerges from the imagination and creative work of the scriptwriter, the art director, the musical composer, the director, and others, but also from the ideas they have about what a credible representation of Japan can be for the target of the movie. In the following sections we analyze the film studying how enunciation develops the two strategies mentioned.

\subsection{Japan through Spain}

The Aichi Expo had a theme, "Nature's Wisdom," and three thematic areas. The Spanish Pavilion chose to focus on the second, "The art of life: Cultures and their coexistence with nature" (SEEI 2005b). This, in turn, was seen from the framework of the Spain Brand Project Manual (SEEI 2005b). It was performed as an explicit desire to seek closer relations between the Japanese and Spanish cultures, enhancing the knowledge of common ground (in traditional activities, customs and habits of consumption) to arrive later at the differences. It was intended to activate a "process of fusion between the two cultures, whose relations began in the seventeenth century" (SEEI 2005b, p. 7).

In this film by B. Pedrosa, the historical links between Japan and Spain are easily perceived through the plot. Gisaku tells the story of a struggle between Good and Evil in which a heterogeneous group of characters are involved. Some are human, such as Yohei, the brave samurai, and the Spaniards Riki, an orphan boy who lives with his tutor Carmona, and Moira, a young scientist. Others are not human, like Gorkan, the terrible demon who wants to rule the world; Linceto, a mutation of the Iberian lynx humanized by Gorkan; and Gisaku, another devil in Gorkan's service. In the Spain of 2005, 
the group led by Yohei had to collaborate to prevent Gorkan from achieving his goal of invading the world with his demonic hordes. The samurai, who arrived in Spain with the first Japanese expedition to Europe and America promoted by Date Masamune at the beginning of the seventeenth century, had waited almost four hundred years in the country to complete the mission entrusted to him: Protect the fragments of the Izanagi key. The key closes a magical door that communicates worlds of different dimensions and that opens every 385 years. It is composed of 5 fragments distributed in different Spanish populations that endow those who possess them with different types of power: Intelligence, nature, imagination, heart and courage. Yohei and his travel companions must tour the Spanish geography to get the different pieces. Thanks to them Gisaku defeats the evil demon in the final fight.

\subsubsection{History}

From a historical perspective, the links between Japan and Spain go back to the period between 1543 and 1643, called by some European historians "the Iberian century of Japan" because it includes the arrival of Portuguese and Spanish merchants and missionaries to the Asian archipelago (Cabezas 1994). These contacts put "the foundations of a process of transculturation called Nanbanjin culture or barbarians" (in the etymological sense of "foreigners") (Guillén Selfa 1997, p. 17). For Europeans of that time, access to other geographies opened the possibility of conquest or commercial relations, but both were necessarily linked to processes of Christianization. With this purpose in 1549 the Spanish missionary Francisco de Jaso y Azpillicueta (1506-1552), better known as Francisco Javier ${ }^{3}$, was sent to Japan to create the mission of the Society of Jesus there. Francisco Javier, a key figure in relations between Japan and Spain, was not an explorer driven primarily by commercial ends, but a missionary who served as a translator and intermediary before merchants and rulers from his role as evangelizer. The film alludes to him, but it is striking that the religious motivation of his trips is omitted. You could even say that his figure appears altered when he is mentioned as "the Spanish Marco Polo, the first Westerner to make an effort to understand Japanese culture." From this is inferred a rather neutral figure that threatens his real missionary status. In our opinion, the reasons for this distortion lie in the belief (possibly more Western than Japanese) that religion is one of those topics that can hurt sensitivities and that should be avoided when facilitating communication.

The Ibero-Japanese contacts were an important element of local culture openness and access to Western technology and socio-political organization, in addition to their first contacts with Christianity. They were possible thanks to the tolerance with which a part of the Japanese rulers welcomed the Westerners, for some time. A key figure in these interactions is the founder of the city of Sendai, daimyo Date Masamune (1567-1636), who became one of the most powerful feudal lords. Date showed sympathy for the European missionaries and was the promoter of the first Japanese expedition to America and Europe. He financed the construction of the ship San Juan Bautista, in which, between 1613 and 1620, a group of almost two hundred Japanese, mainly merchants, travelled to the viceroyalty of New Spain in America (Mexico) and Spain, as well as the Vatican. The expedition was led by the samurai Hasekura Rokuemon Tsunenaga (1571-1622) who visited the cities of Seville, Madrid and Barcelona, and was baptized as Felipe Francisco de Fachicura. His embassy is known as the Keicho mission, although it was not as profitable as expected, due to complex political conflicts (Cabezas 1994; Guillén Selfa 1997).

In the movie, Yohei's character functions as an alter ego of Hasekura. In the dense flashback explaining his origin, Yohei justifies his presence in the Spain of 2005 clarifying that he arrived in 1620 as a member of an expedition of samurai in the service of Date Masamune. This five-year trip is summarized by a voice-over while the ship is shown following the American-European route on a map of that time. Like Hasekura, Yohei is sent to Spain with an important mission. His visit will allow him

3 Francisco de Jaso, lord of Castle of Javier, was a prominent member of the Catholic religious order Compañía de Jesús. He was canonized by Pope Gregory XV in 1622. He was also appointed patron of tourism, in 1952, by Pope Pius XII. 
to get to know some of the most emblematic Spanish cities, including the three visited by the historical Hasekura. Thanks to a lethargy of legendary dyes, Yohei remains alive and young in Seville's subsoil for almost four centuries. With this, his character fulfils the function of a bridge between the two temporal periods represented in the narration. In this way, the ideal viewer of the film visits with Yohei the times and places represented when he shares with the samurai his fictional adventures.

\subsubsection{Nature}

In addition to the historical connections, another way established by the SEEI to develop the thematic area "The art of life: Cultures and their coexistence with nature" was to convey the idea that the protection of the environment is important in Spain. This can be detected in the prominent role of fictional natural spaces. But in turn it connects with the importance that nature has in Japanese culture. Let us recall that the ancestral roots of Nipponese history have a key reference of a mythical-religious character in the Kojiki, the oldest surviving book about the history of the country. In it the origins of the country are narrated from a legendary perspective, from the creation of the world by two kami or divinities, Izanagi (god of life associated with the creation of the world) and Izanami (goddess of death). According to this Shinto symbology, kami are mysterious and undefined entities related to "numerous forces of nature (fountains, mountains, waterfalls, rivers, special locations)" (Sullivan 2008, p. 22). "The meaning of life, solidarity with the natural world and with society as a whole" (ibid., p. 36) depend on kami.

Regarding Gisaku, it is evident that nature is not represented in a spiritual, mythological or religious way, but rather by more functional and realistic references, as well as promotional ones to spread an internationally unknown aspect of Spanish landscape. We see, for example, vineyards linked to a wine cellar in a famous wine producing area (La Rioja). However, there are several highly relevant spaces that are engaging, due to their attractiveness, but above all because of the unusual selection criteria, since they do not usually function as dominant tourist claims of Spain. They also seem to differ significantly from the tourist iconography of Spain usually seen in Japan (Centeno Martín 2017a).

Surely the most outstanding element in this category is the representation of the Jerte Valley (Extremadura), with the spring beauty of its fields of cherry blossoms, green hills, and crystalline waterfalls. The cherry tree is a very important tree in this region, valued mainly for its fruit (these cherries have a Designation of Origin ${ }^{4}$ ), and the area is a well-known rural destination for Spanish tourism. But the cherry tree would not be one of the most striking or typical trees of Spanish flora, nor the Extremaduran Valley one of the most popular natural enclaves. In Japan, on the other hand, the cherry blossom is perceived as a metaphor for the ephemeral character of life. This charismatic flower for many Japanese people is a cause for celebration, in the traditional Hanami ${ }^{5}$ festival, as well as for poetic or legendary creation. No wonder that Yohei feels that "It's like being back home".

Similarly, it is striking that the animal component of Linceto does not correspond to that of a particularly popular animal in Spain, nor is it frequent in legendary tales. The Iberian lynx (Lynx pardinus) is a species known because it is in danger of extinction, and therefore protected by authorities. In addition, Linceto is linked to a very specific environment, the Doñana National Park (Andalusia), an area known in Europe since the nineteenth century mainly for its relevance to migratory birds. Ultimately, the final fight between Gorkan and Gisaku takes place on an uninhabited island that evokes Dragonera Island (Balearic Islands), a place used for defensive purposes in previous centuries and also declared a protected space four decades ago.

This selection of rare natural references to represent Spain in the movie and its close connection with the plot suggest the textual construction of an implicit spectator whose captatio benevolentiae

4 Denominación de Origen or Denominación de Origen Protegida $(D O / D O P)$ is part of a regulatory classification system of quality and geographical origin used primarily for Spanish wines, but also for other kinds of food.

5 The Hanami festival literally means "go see the flowers" and it is celebrated in spring. Numerous people congregate under the cherry blossoms to enjoy the beauty of the environment, drink and sing. 
is intended to be achieved by showing a version of reality that can easily connect with him on an emotional level. It infers, thus, a viewer more interested in natural unmodified landscapes than in those transformed by man, sensitive to the protection of endangered species and the ludic-poetic potential of the fields of cherry blossoms, more inclined by the explosion of spring life in inland landscapes than by summer beach and sun. It would be, in short, a spectator who is not only educated in nature's respect and care, but who also is particularly receptive to the presence of natural heritage because he or she is capable of attributing to it a value that includes, but also transcends, its topographic and aesthetic dimension.

\subsubsection{Cultural Connections}

A third link between both countries that follows what was prescribed by the Spain Brand Project manual would correspond with the identification of certain Japan-Spain cultural connections, among which gastronomy and art occupy a prominent place. It is true that both manifest themselves differently in each culture. At the same time, they are very important in both Spanish and Japanese cultures (Abad Zardoya 2011; González-López 2018). The film shows a great effort to present these themes in different ways, including a latent message of cultural fusion.

The references to Spanish gastronomy are neat in Gisaku, even excessive in some scenes. The scriptwriter of the film Angel E. Pariente has affirmed that: “( .. ) in my opinion there are eight minutes of film that are too much... Perhaps the clearest example is the scene of the wines and the food" (Pariente 2006). There are also evident references to some elements of coincidence between both countries, such as the high consumption of fish, with Japan being the country that leads the international ranking in this regard. Another element of union is the reference to a well-known Japanese culinary technique, the tempura ${ }^{6}$, similar to fried fish which is typical in the region where the protagonist child lives. Apart from these explicit mentions, there is also an implicit reference to the Japanese culture through the Spanish one. This is seen in the prominent place occupied by the gastronomic and hospitality protocols the guest Yohei seems to enjoy as much as Riki and Carmona. The rituals, the dishes and the surroundings are shown following the conventions of the host country, and a very great deal of trouble has been taken with the details of the sequence. Furthermore, an unspoken message is transmitted: The idea that when sitting around a table, which products are served are as important as the way and place where they are consumed, not to forget certain courtesy and hospitality rules towards the guests. If any doubt about the extent to which the interest in gastronomy is shared in both cultures could remain, the final sequence dissolves it definitively. When Yohei decides to stay with his new Spanish friends in Seville, he opens a tavern called "The Japanese." From there he honours his clients with Japanese hospitality, adopting the role of host in a foreign country. The film closes, then, with an exemplary scene of cultural transnationalities although the transformational arc of this character is weakly profiled.

It can also be noticed that there is an appreciable effort to establish literary connections, both real and fictitious, that may awake interest in the implicit audience. The recognition by Yohei that the symbol embedded in an old cane from Carmona will lead them to share information about Don Quixote (1605), by Miguel de Cervantes, as well as about Spanish Maecenas that Yohei personally knew in the 17th century. In addition, the work contains a connection with Gorkan through a fictitious secret code inserted in the original, The Da Vinci Code style. It is not happenchance that Carmona's profession is that of an antiquarian, which justifies that his house is full of works of art that are shown in several scenes; nor that he appears managing by telephone pictorial collections of important Spanish painters in the final sequence. The plot still goes a step further towards favoring East-West links by showing Carmona sharing this painting business with Drela. Thus, she also ends up integrating herself into everyday Spanish life by contributing her skills to the local artistic field.

6 Tempura has been attributed by some historians to the influence of the Portuguese-Spanish missionaries (Guillén Selfa 1997). 
Finally, another aspect that is not very frequent in Spanish cinematography, but that appears repeatedly in Gisaku is the presence of the Spanish forces of order. Its hypervisibility is of questionable narrative usefulness, because although they appear in several cities (Valencia, Santiago, Seville and Barcelona) arriving with alacrity at the altercations provoked by Gorkan, we do not see that they manage to solve the problems. Its function seems to be more discursive than narrative. The aim is to transmit an image of tranquillity in terms of citizen security that directly addresses Japanese viewers, specifically those who expressed concern about the subject in the opinion study on the image of Spain carried out by the SEEI.

\subsection{Japan through Japan}

The other strategy of approaching the Japanese audience derives from the representation of elements that evoke Japan in a more direct way. We will try to explain how the Spanish creative team looks at the other-Japanese-culture to select some national items accessed through certain channels of interaction, and then handles them in its own way to send them back to the Nipponese target of the movie in a sort of two-round transcultural movement.

\subsubsection{Anime Animation}

As we pointed out above, an obvious, a priori, stamp of national agency is the type of animation chosen. Gisaku was promoted as the first Spanish anime film, given that this was a form of animation practically unexplored so far by European industry. It can be inferred that this was intended to facilitate the acceptance of the film by Japanese spectators, apparently great fans of its own animation, since anime "is a truly mainstream pop culture phenomenon" (Napier 2008, p. 7), especially among young people. Working for the first time with anime conventions was not easy for the Spanish art team. Art director Carlos Ruano explained, for example, that

The truth is that the animators did have a hard time at first with not forcing a movement, or leaving the character fixed while speaking, but little by little we got it right. Leaving poses in a plane implies that the pose is very studied and very aesthetic, otherwise it would not hold on screen so long. We had to sacrifice action of movement for composition and visual effect (Ruano 2006).

However, Gisaku is not completely an anime movie. Rather, it is an experiment built with a mixture of production styles and techniques that hinder its classification and eventually its acceptance. The film was exhibited in Spanish cinemas as a regular fiction anime movie in 2006, which probably raised high expectations among Spanish otaku who maybe dreamt of a sort of Spanish Akira (1988), by Katsuhiro Otomo. The lack of information about the promotional aims of Gisaku probably favored some misunderstandings and disappointments about the movie ${ }^{7}$. More than following anime according to commonly agreed conventions (Denison 2013; Macwilliams 2008; Napier 2008), it is a Western-style animation $^{8}$ with a careful design of the backgrounds, Western character features and, at the same time, obvious winks at anime: Big-eyed characters, fight scenes, time suspension, thematic samurai, conflicts of the Shonen genre (for teenagers), etc. In the words of the film director B. Pedrosa:

7 The main negative comments spread through the internet (blogs, forums, and so forth) pointed to the fact that it was not an actual anime film, it was for children and the promotional contents were too obvious. Those who were aware of the actual nature of the film highlighted the risk of the project, the authenticity of the fight scenes, and the quality of the images, and regretted the pressure (in terms of short production time and institutional control) that impeded a more accurate final product. See, for example, comments on FilmAffinity, https://www.filmaffinity.com/es/film820786.html; the post "Gisaku, dull katana" and its comments on http://elsenordeloschupetes.blogspot.com/2005/12/gisaku-katana-sin-brillo.html; or "'Gisaku': [S]amurai in Spain or the Cervantes code" on https://www.espinof.com/estrenos/agisakua-samurais-enespana-o-el-codigo-cervantes.

8 Spanish characters in the movie look like some American cartoons. For instance, Moira reminds us of TV series, such as Disney's Kim Possible (2002); Riki evokes the boys in The Mummy: The Animated Series (2001) produced by Universal Cartoon Studios. 
We obviously decided to maintain anime aesthetics, use its freedom in terms of narrative resources and cinematographic language but, without it seeming like a copy of Japanese anime. We wanted to contribute something of our own, something more Latin, more European. We wanted to enjoy the work and make that appear in the film. Technically, the film is the fusion between Eastern and Western forms of work, fulfilling one of the initial premises in the idea of the project, the approach of cultures. Finding that balance on the part of the team was the main technical difficulty to overcome, as well as the pressure exerted by the production time that did not permit many tests or improvisations (Pedrosa 2006).

C. Ruano refers similarly to the intended (non) agency of anime conventions:

The first thing we had to take into account was anime aesthetics: Big eyes, shine in the hair, its figurative style ... and of course, its characteristic animation. At the same time, it also has Western or Spanish contributions, some sought after and others that came unintentionally. In many cases the animation moves away from anime and approaches western codes. Some characters' traits, like Gisaku's himself, are quite "Disney style" (Ruano 2006).

The film was not released in the impenetrable Japanese commercial market, so it is impossible to have data on an eventual reception of the movie in its cinemas. Yet, there are some indicators taken from the opinion poll conducted by Sendai's International Relations and City Promotion Section among the viewers who watched the film at the Aichi Expo ${ }^{9}$. It is noteworthy that its stylistic impurity or its promotional nature was not perceived as a lack or deficiency. On the contrary, the reception was generally positive ${ }^{10}$. In some cases, even surprise was expressed by the presence of references to the history of Japan in the plot of a foreign film and the high quality of the little-known Spanish animation (SEEI 2005a). Ruano (2006) also tells the anecdote that "It is true that we were told that they [some spectators] saw Riki as being very Japanese and they expected him to have more Spanish features." And he adds an interesting interpretation regarding transnational exchange: "This struck us quite a lot. I think they have adopted the aesthetic of big eyes as their own, and they really see themselves that way".

\subsubsection{Religion}

The movie also contains elements that evoke the Japanese Shinto religion and culture as well as Japanese Buddhism through its free representation by manga and anime (Macwilliams 2008; Sullivan 2008). We see fantastic characters, headed by the great demon that gives title to the film and whose name also suggests clearly oriental connotations. Gisaku, who joined Yohei after facing him in the seventeenth century, remains in Spain asleep inside a stone sculpture close to a Christian church, protected by the peaceful environment of the Jerte Valley. It appears as an animal resembling a cross between a lion and a dog that evokes Japanese Shinto komainu. As lions do in the Buddhist tradition, komainus are wards that protect from some evils and are usually placed in pairs. In fact, there is another ice sculpture of Gisaku at the very end of the movie, in the mysterious epilogue that finishes the narration with an open ending. When Yohei needs his help, he approaches the surroundings of the sacred place and, with a technique that evokes oriental purification rituals (burning some sticks of incense), the figure reverts to its animate state and becomes a small lion's cub, the size of a dog. On the other hand, Gorkan also has the capacity to transform himself, although in his case the change is to human form. His assistant Drela is an attractive woman with Asian features who serves him loyally

9 There were 250 spectators who watched the movie of whom 118 formed a focus group to answer questions about the movie. Most of them were adults, including 53 women.

10 This positive reception of an advertising anime fiction story might be similar to the surprise and positive comments that the short Japanese anime movie Xi Avant (2011), by Kenji Kamiyama, got when Spanish spectators recognized Barcelona and the Sagrada Familia Cathedral in it. See, for example, comments on this blog: http://laarcadiadeurias.com/anime/xi-avant/. 
until his evilness is neutralized thanks to the amulet given by Yohei to Carmona and the Japanese magic words "Mukashi, mukashi" (meaning "Once upon a time"), showing the power of fairy tales.

This way, Gisaku includes divine entities, such as Gorkan and Gisaku, linked to life and death (like Izanagi and Izanami); beings that can adopt animal forms, either alive or as komainu, as well as anthropomorphic ones; a living being can have more than one form of existence and superhuman powers, just as kami can; there are magical objects (fragments of the Izanagi key) capable of transmitting powers, such as valor, to the world of the living; Divinity can be invoked through sacred rituals; there are stones and magic words that protect against evil beings; there are magic doors that manage temporality from a non-linear dimension ...

\subsubsection{Samurai}

Another obvious Japanese element is the character of the samurai. Icons of traditional Japanese culture, these warriors and their code of ethics or bushido are part of the historical past, while they have become a cultural legacy through values such as honour, hierarchy, loyalty, and discipline, that remains through time (Barlés Báguena and Emeterio 2011; Rodríguez Navarro 2011). It is also the central element in manga, anime and video games of samurai matter (Rodríguez Navarro 2011; Macwilliams 2008); and it has been present in Spanish imagery about Japan for a long time. The image of Japan in Spain has been subject to major changes throughout history depending mainly on the existence of conflicts or political interests between the governments of both countries at critical times (Rodao García 2002), and the strength of cultural and art ties such as international exhibitions (Almazán Tomás 2006), among others. There is a curious historic connection with two topics dealt with in the film, samurai and technology, that goes back to the first years of the Franco dictatorship in Spain. At the beginning of his dictatorship and for a short period of time, Japan had a positive image in Spain. For political reasons, the Nipponese culture was considered as different to other Asian ones, according to Florentino Rodao García (2002). Japanese otherness was based "on the growing domain of modern technology along with the bushido code of military values that seemed to be a parallel of the traditionalist and fascist-modernist hybridity of the Franco regime" (Payne 2002, p. 6). The Japanese Empire was regarded as the alter ego of Spanish nationalists, which should continue the crusade against communism in Asia (Centeno Martín 2017b). In spite of the enormous temporal and cultural distance that separates the production conditions of Gisaku from the Franco era and its changing imaginary about Japan, it is nevertheless striking that the film evokes precisely those same traits. The message sent by the film maintains the connection with the idea of tradition. However, the fascist connotation is completely absent and is replaced by a positive idea of innovation and progress.

The simplest versions of the complex universe of samurai seem to have inspired the creative team of Gisaku, mainly because of the simplicity of the character's psychology. Although Yohei is brave and responsible in fulfilling his mission, Gorkan's great power transcends his skills. His unawareness of the Spanish geography and the technological resources necessary to find the Izanagi key force the samurai to work in a group. Yohei receives the help and admiration of Riki when he joins him. Yohei helps Riki to trust in himself, to realize that he does not need Izanagi's piece to face difficulties with courage. Something similar happens with Moira and Linceto. Teamwork implies the acceptance of the peculiarities of each individual and the support of the group, which is not only effective against Gorkan, but favors attitudes of honesty and commitment among the characters. By transmitting positive values, such as teamwork and mutual respect, the film satisfies one of the recommendations of the Spain Brand Project manual. But it also gets another unwritten goal, which is to approach the type of conflicts and messages of the anime genre Shonen (Napier 2008; Macwilliams 2008). However, the samurai is a rather flat character because there is no internal struggle of forces that confers psychological complexity. A character with differentiating features and conflicts, as round characters, may be potentially more interesting, but may also provoke rejection more easily. In contrast, a flat character is very easy to identify, although it may be less attractive. Given that creating a foreign character who must be welcome by its native audience is a sensitive responsibility for an author, 
especially when representing a culture without any real first-hand knowledge, it is our guess that the shortest route would be to choose the stereotype. Maybe that is why Yohei is shown as a friendly person who has everything a samurai needs: His bushido skills and a goal to fulfil.

\subsubsection{Technology}

One noteworthy aspect of the film is the treatment of the scientific-technological matter, another institutional objective selected to show contemporary Spain, but probably something else. Japan's current link with technology is a recurrent element in the Western imagination of the country, inside and outside the universe of anime. Furthermore, it was also promoted as a Japanese feature among Spaniards in pre-democratic decades, as described above, but with very different meanings. In the movie, the Spanish administration records its little known scientific and technological advances (space technology, scientific research centre in Antarctica, wind energy, Nobel prizes), shown also through the gadgets that help to defeat Gorkan (a balloon that works with biogas, a boat that works with solar energy, etc.). By doing this, it not only makes a proud display of its heritage in front of native viewers in a country that is a global leader in technology, but it also tries to make a positive impression on them. Along with the amiable version of the technological issues, the film also dares to reveal its dark side by staging unorthodox devices to keep control over citizens. The fact that the character being monitored is evil Gorkan does not make it any less worrisome.

\subsubsection{Tourists}

Finally, it is worth quoting a scene that can be seen to be a nice joke about Japan. Both countries share common interests in tourism, Japan being both attractive to foreign tourists and the origin of an appreciable flow of visitors to other countries. These potential travellers to Spain are the actual target audience of the movie, although they are briefly represented. At the beginning of the film, the samurai meets some Japanese tourists who, like him, discover Seville in 2005. Surprised and happy to discover his compatriots who quickly take a picture of him, Yohei asks them which clan they are from and if any of them are from Sendai. With a friendly allusion to the stereotype about the omnipresence of Japanese tourists in the West and their traditional interest in photographic captures, Riki says that they belong to the "clan of tourists".

\section{Conclusions}

Gisaku (2005), by Baltasar Pedrosa, is a unique Spanish cartoon movie produced to sell Spain's country brand to the visitors attending the Spanish Pavilion at Expo Aichi 2005. It builds a fantastic plot combining information coming from the theme of the Expo, focused on nature and Spain's institutional mission of showing a good image of Spain, which includes the aim of pleasing the target audience by portraying an acceptable picture of Japan. This little-known film may be considered an opportunistic, weak and unmarked transnational film, but it still shows very interesting and renewed forms of transnational exchange. Given the fact that very little information about the audience is available, the movie is analyzed from a narratological perspective in order to trace the narrative strategies used to construct the implied spectator and the terms in which his or her national identity is constructed. This approach shows that there are two main frameworks that guide this engagement with the Japanese audience. They appear in the story, and both narrative and production discourse. Firstly, the movie offers a representation of Spain's national identity by using some singular features of Spanish culture that can be particularly attractive to Japanese spectators, thus shaping Spanishness from an otherness for marketing reasons. Although it does not show a false or implausible image of Spanish culture, it is modelled using both common and uncommon features and modes of representation. It looks like an interesting case of national self-representation shaped to suit a foreign audience of potential tourists. The historical presence of Japanese visitors in Spain in the 17th century, cherry blossoms in the Jerte Valley or the importance of art and gastronomy might be some good examples. Secondly, there are some elements that are easily recognizable as Japanese icons from a Western perspective 
and which have been appropriated in novel ways. The most obvious detail is a title that sounds Japanese, but one of the most remarkable features is the hybrid identity of the anime animation in the film (using partly anime and partly Western/Spanish codes). This is not free from serious risks, especially among those who might regard this impurity as failure or negligence. Moreover, the story contains the character of a samurai with bushido skills who in the last scene puts fighting aside to open a Japanese tavern in Seville. He is an uncomplicated character built from friendly stereotypes probably to facilitate acceptance by the target audience. But unexpectedly and unjustifiably, he also breaks the mold of the classic samurai to accommodate the changing times in a foreign country right before the movie ends. In this way Gisaku shows a particular appropriation of a strong icon related to traditional Japan, but also permeable to the power of the tourism industry in the twenty-first century. Samurai, along with technology, are stereotypical features of Japanese culture that are shown in positive terms of progress in Gisaku. Some Shinto traditions filtered through the anime universe are also present in the movie. It is recognizable in non-human characters, such as Gisaku who can be a fearsome evil, a cross between a lion and a dog, or adopt a komainu appearance when no fight is required. This is an unknown aesthetic territory in Spanish animation productions that expand them towards unexplored borders. At the same time, it can be said that Japanese national identity reaches Spain through some exported/imported features and goes back to Japan as an expanded national imagery. This transnational exchange is negotiated within the framework of both old and renewed modes of representation of images and stereotypes by Spanish creators. No doubt Gisaku rewrites the boundaries of film animation and representation of nationhood regarding the two national identities involved in the movie.

Funding: This research received no external funding.

Acknowledgments: The author thanks SEEI for the helpful documentation provided for the research on the film. She also thanks the movie's director, producer, scriptwriter and art director for kindly agreeing to be interviewed in personal communications.

Conflicts of Interest: The author declares no conflict of interest.

\section{References}

Abad Zardoya, Carmen. 2011. El japonismo en la cultura gastronómica occidental. Historia de una seducción. In Japón y el Mundo Actual. Edited by Elena Barlés Báguena and V. David Almazán Tomás. Zaragoza: Prensas Universitarias de Zaragoza, pp. 1051-64.

Almazán Tomás, V. David. 2006. Las exposiciones universales y la fascinación por el arte de Extremo Oriente en España. Japón y China. Artigrama 21: 85-104.

Barlés Báguena, Elena, and Aurora San Emeterio. 2011. Algunas notas sobre la imagen del Japón tradicional a través de los videojuegos. In Japón y el Mundo Actual. Edited by Elena Barlés Báguena and V. David Almazán Tomás. Zaragoza: Prensas Universitarias de Zaragoza, pp. 767-820.

Cabezas, Antonio. 1994. El siglo ibérico de Japón. La presencia hispano-portuguesa en Japón (1543-1643). Valladolid: Universidad de Valladolid.

Casetti, Francesco. 1986. Dentro lo sguardo. Il film e il suo spettatore. Milano: Bompiani.

Casetti, Francesco, and Federico Di Chio. 1990. Analisi del film. Milano: Bompiani.

Centeno Martín, Marcos. 2017a. Del Viaje del Turista Al Viaje del Héroe. Mímesis Cinematográfica del Discurso Turístico Japonés Sobre España. El Caso de Andarushia (2011). Mirai. Estudios Japoneses 1: 89-107. Available online: https:/ / revistas.ucm.es/index.php/MIRA/issue/current (accessed on 7 September 2018). [CrossRef]

Centeno Martín, Marcos. 2017b. Transnational Circulation of Images of the Pacific War (1941-1945). The Japanese Empire Seen Through Spanish Newsreels. The Irish Journal of Asian Studies 3: 1-17. Available online: https: //irishjournalofasianstudies.files.wordpress.com/2018/01/ijas3_centeno4.pdf (accessed on 7 September 2018).

Chatman, Seymour. 1978. Story and Discourse: Narrative Structure in Fiction and Film. Ithaca and London: Cornell University Press. 
Denison, Rayna. 2010. Transcultural creativity in anime: Hybrid identities in the production, distribution, text and fandom of Japanese anime. Creative Industries Journal 3: 221-35. [CrossRef]

Denison, Rayna. 2013. Anime, a Critical Introduction. London: Bloomsbury.

Durand, Gilbert. 2004. Las Estructuras Antropológicas del Imaginario. México City: Fondo de Cultura Económica.

Elsaesser, Thomas. 2005. European Cinema. Face to Face with Hollywood. Amsterdam: Amsterdam University Press.

Gaudreault, André, and François Jost. 2004. Enunciation and Narration. In A Companion to Film Theory. Edited by Toby Miller and Robert Stam. Oxford: Blackwell Publishing Ltd., pp. 45-63. First published 1999.

Genette, Gérard. 1998. Nouveau Discours du Récit. Paris: Editions du Seuil. First published 1983.

Genette, Gérard. 1972. Figures III. Paris: Editions du Seuil.

González-López, Irene. 2018. In Search of the Authentic Japanese Taste: Solitary Gourmet and Cultural Tourism. Mirai. Estudios Japoneses 2: 49-66. Available online: https://revistas.ucm.es/index.php/MIRA/article/ view / 60495 (accessed on 7 September 2018).

Guillén Selfa, José. 1997. La Primera Embajada de Japón a Europa y en Murcia (1582-1590). Murcia: Editora Regional de Murcia.

Highson, Andrew. 1989. The Concept of National Cinema. Screen 30: 36-47. [CrossRef]

Hjort, Mette. 2010. On the plurality of cinematic transnationalism. In World Cinemas, Transnational Perspectives. Edited by Kathleen Newman and Natasa Durovicova. New York: Routledge Editors, pp. 12-33.

Lippmann, Walter. 1997. Public Opinion. New York: Routledge. First published 1922.

MacDougall, David. 1998. Transcultural Cinema. Princeton: Princeton University Press.

Macwilliams, Mark Wheeler. 2008. Japanese Visual Culture: Explorations in the Workd of Manga and Anime. New York: M. E. Sharpe.

Mestre, Rosanna. 2007. Anime español para otaku japoneses. In Cine, imaginario y turismo. Estrategias de seducción. Valencia: Tirant lo Blanch, pp. 211-41.

Napier, Susan J. 2008. From Impressionism to Anime: Japan as Fantasy and Fan Cult in the Mind of the West. New York: Palgrave Macmillan.

Noya, Javier. 2002. La imagen de España en el exterior. Estado de la cuestión. Madrid: Real Instituto Elcano.

Noya, Javier. 2004. La imagen de España en Japón. Madrid: Real Instituto Elcano.

Pariente, Ángel E., and Gisaku Film Scriptwriter, Spain. 2006. Personal communication.

Payne, Stanley G. 2002. Prólogo. In Franco y el imperio japonés. Imágenes y propaganda en tiempos de guerra. Edited by Florentino Rodao. Madrid: Plaza y Janés.

Pedrosa, Baltasar. 2005. Gisaku. Cómic-libro de la película. Barcelona: Filmax-SEEI.

Pedrosa, Baltasar, and Gisaku Film Director, Spain. 2006. Personal communication.

Rodao García, Florentino. 2002. Franco y el imperio japonés. Imágenes y propaganda en tiempos de guerra. Madrid: Plaza y Janés.

Rodao García, Florentino. 2005. La Imagen de España en Asia-Pacífico. Madrid: Real Instituto Elcano, Available online: http://www.realinstitutoelcano.org/wps/portal/rielcano_es/publicacion?WCM_ GLOBAL_CONTEXT=/elcano/elcano_es/publicaciones/la+imagen+de+espa_a+en+jap_n (accessed on 7 September 2018).

Rodríguez, Paco, and Gisaku Producer, Spain. 2006. Personal communication.

Rodríguez Navarro, María Teresa. 2011. La presencia del Bushido en el Japón actual. In Japón y el mundo actual. Edited by Elena Barlés Báguena and V. David Almazán Tomás. Zaragoza: Prensas Universitarias de Zaragoza, pp. 237-60.

Ruano, Carlos, and Gisaku Art Director, Spain. 2006. Personal communication.

Sociedad Española de Exposiciones Internacionales (SEEI). 2003. Selección de Empresas para Concurso de Primeras Ideas, producción audiovisual de animación, $\mathrm{n}^{\circ}$ de referencia 2105/01. Unpublished document accessed by author with SEEI permission. Unpublished Work.

Sociedad Española de Exposiciones Internacionales (SEEI). 2005a. Informe Preliminar. Pabellón de España Expo 2005 Aichi, Unpublished document accessed by author with SEEI permission. Unpublished Work. 
Arts 2018, 7, 93

Sociedad Española de Exposiciones Internacionales (SEEI). 2005b. El Proyecto Marca España en la Exposición Universal Aichi 2005. Manual Proyecto Marca España-Japón. Madrid: Proyecto Marca España.

Sullivan, Lawrence E. 2008. Naturaleza y rito en el sintoismo. Donostia-San Sebastián: Editorial Nerea.

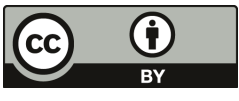

(C) 2018 by the author. Licensee MDPI, Basel, Switzerland. This article is an open access article distributed under the terms and conditions of the Creative Commons Attribution (CC BY) license (http:/ / creativecommons.org/licenses/by/4.0/). 
Article

\title{
Intertextuality and Mise en Abyme in Nobuhiro Suwa's H Story and A Perfect Couple. Between European Modernity and Japan
}

\author{
Miguel Muñoz-Garnica \\ Department of Audiovisual Culture and Communication, Universidad de Navarra, 31009 Pamplona, Spain; \\ mmunozg@alumni.unav.es
}

Received: 31 August 2018; Accepted: 25 September 2018; Published: 1 October 2018

\begin{abstract}
Suwa Nobuhiro, often called "the most French of Japanese directors", has a complex relationship with European cinematic modernity. His two feature films H Story (2001) and A Perfect Couple (2005) can provide useful case studies, as they were created in dialogue with two key references of that modernity: Hiroshima mon amour (1959, Alain Resnais) and Journey to Italy (Viaggio in Italia, 1954, Roberto Rossellini), respectively. Both films tend to confront and gloss their previous pairs, but they are also continuations of their concerns and their aesthetical discoveries. The presence of intertextuality elements connecting those films, as well as the use of myse en abyme structures are deeply analyzed in this article to attain a greater understanding on how this process of transcultural dialogue works. Besides, both films exemplify different ways of developing the references on which they are built, namely deconstruction for $H$ Story and reconstruction for A Perfect Couple.
\end{abstract}

Keywords: contemporary Japanese cinema; cultural blending; intertextuality; mise en abyme; Nobuhiro Suwa; transculturality; (trans)national cinema

\section{Introduction. Nobuhiro Suwa and European Modernity}

"If modern cinema was already a post-cinema, what about cinema that watches and is inspired by it today?" asks Cahiers du cinéma critic (Joyard 2001, p. 68) in the introduction to his article on H Story. This question may be the most appropriate one in addressing the work of Japanese director Nobuhiro Suwa, whose complex relationship with European cinematic modernity is at the same time one of quotation and gloss, of continuity and confrontation. As this article explores, his third and fourth features, H Story (2001) and A Perfect Couple (Un couple parfait, 2005), are constructed in dialogue with two key references of that modernity: Hiroshima mon amour (1959, Alain Resnais) and Journey to Italy (Viaggio in Italia, 1954, Roberto Rossellini), respectively. In a similar way, his most recent film, The Lion Sleeps Tonight (Le lion est mort ce soir, 2017), builds its main character by assimilating into the fiction the cinephilic echoes of the actor who plays him: the Nouvelle Vague icon Jean-Pierre-Léaud. Suwa tends to draw his films from the cinema he loves, and this relationship, far from being merely anecdotal, constitutes the creative basis on which he works.

Suwa himself admits that discovering classical Hollywood at the same time as the Nouvelle Vague while he was studying at Tokyo Zokei University was his "introduction to movie-making". Feeling "desperation" with regard to contemporary Japanese cinema, he developed his strong interest in "directors whose cultural origins are complex", his fascination with a Nouvelle Vague that he considered a continuation of Alfred Hitchcock as much as of Roberto Rossellini (Fraga 2018) ${ }^{1}$. Therefore, Suwa seems to be well aware of the transnational influences that have earned him the title of "the most

1 All translations from French and Spanish are by the author unless otherwise noted. 
French of Japanese directors", a perspective that was already applied to him on the basis of his first and second features, 2/Duo (2/dyuo, 1997) and M/Other (1999), fully produced in Japan but dealing with the staple topic of modern cinema in the sixties: the couple in crisis (Font 2012, p. 519).

To understand in which cultural discourse Suwa's images are rooted, it is important to clarify the concept of "European modernity". Quintana (2007, pp. 58-60), who frames the director as one of the main examples of the last decade's aesthetic migrations from European modernity to Asian cinema, includes in this concept the films that derive from the developments following the first wave of Italian Neorealism to the new cinemas of the sixties. He also summarizes its spirit in the ideas of three essential authors: André Bazin (2005, pp. 9-16) theories about the ontological capacity of cinema to capture the "ambiguity of reality"; Jacques Rivette (1955) Lettre sur Rossellini, in which, inspired by the release of Journey to Italy, the critic and subsequent filmmaker describes Rossellini's film as a new turning point in modern cinema due to his use of "suspended time" and centreless frames; and the concept of "image-time" coined by the French philosopher Gilles Deleuze (Deleuze 1989, pp. 34-43), who stated that the cinematic image created by modernity lost its condition of a piece connecting, among the other pieces, a unique action, perception or affection that signified the whole film: instead, every piece, or every "image-time", drew attention to itself and its own values. In the origin of these new ways of creating and experiencing the cinematic image is the awareness of brutality (caused by World War II, the concentration camps and the bombs in Hiroshima and Nagasaki) that led to the rejection of classical cinema's "illusion" and its industry's "alienation". Modern cinema was born, as Serge Daney (1983, p. 172) puts it, "in destroyed and traumatised post war Europe, on the ruins of annihilated and disqualified cinema, on the fundamental refusal of the fake, of mise en scène, of the stage $\mathrm{e}^{\prime 2}$.

To return to Joyard's words, if cinematic modernity is characterized by an intentional and conscious reinterpretation of previous cinema, Suwa as a director who questions that modernity may well be part of post-post-cinema. Nouvelle Vague cinema, as the early works of Jean-Luc Godard perfectly exemplify, dialogued openly with the genre patterns of classical Hollywood, in a mixed relationship of admiration and critique. Suwa's cinema, as this article shows, likewise engages in a twofold exercise of imitation and dialogue as well with some key films of European modernity. Two concepts from semiotics are used to focus the analysis: intertextuality and mise en abyme.

Intertextuality is a concept that Genette (1997, pp. 1-2) defines as "the effective co-presence of two texts" in the form of quotation, plagiarism and allusion. Stam et al. (2005, p. 211), who study filmic intertextuality, add that "quotation can take the form of the insertion of classic clips into films", whereas "allusion can take the form of a verbal or visual evocation of another film, hopefully as an expressive means of commenting on the fictional world of the alluding film". Suwa's usual employment of quotation and allusion allows us to trace his dialogue with European modernity. However, there is a special kind of intertextuality that, in addition to this, also discloses how the Japanese filmmaker appropriates the aesthetic discoveries of modernity. Stam calls it intratextuality, "the process by which films refer to themselves through mirroring, microcosmic, and mise en abyme structures". Mise en abyme is a term coined by writer André Gide: "In a work of art, I rather like to find thus transposed, at the level of the characters, the subject of the work itself. Nothing sheds more light on the work or displays the proportions of the whole work more accurately". For a better explanation of the concept, Gide made "a comparison with the device from heraldry that involves putting a second representation of the original shield 'en abyme' within it" (Dällenbach 1989, p. 7). Intertextuality and mise en abyme are two common practices in a European modernity much more concerned about the act of representation itself than the cinema that preceded it, as well as key practices in Suwa's films.

2 Translated from French by Laurent Kretzschmar and Otie Wheeler, 2013. Retrieved from: http:/ / www.sergedaney.blogspot. com/2013/08/la-rampe-bis.html. 


\section{Deconstruction: H Story}

Suwa's third feature-length production and the first to be filmed in Japan with French participation, $H$ Story is undoubtedly the film that best illustrates its maker's complex intertextual relationship with European cinematic modernism, in general, and one of its emblematic works, in particular: Hiroshima mon amour. Interestingly, both films were the product of transnational partnership projects. In its initial form, Hiroshima mon amour was to have been a documentary produced by the Japanese company and directed by Resnais, who had just screened his cinematic essay on the Holocaust, Night and fog (Nuit et brouillard, 1955), to notable acclaim. However, Resnais felt that he would merely repeat what he had done in Night and fog, and that no further documentary on the subject was required given those already made by Japanese filmmakers; so he commissioned a script from the writer Marguerite Duras, a fictional love story set against the backdrop of the bombs (Armes 1968, pp. 66-67). H Story grew from a partnership project about Hiroshima pitched to Suwa by the American filmmaker Robert Kramer. Both men had a stake in the story: Kramer's father had been an airman who flew in a US reconnaissance mission after the bombing and was struck almost completely dumb, rendered "practically autistic", by what he saw; while Suwa himself was born and raised in Hiroshima. Suwa described the proposed project as follows:

We had decided to film one another with two cameras, looking at one another and talking about Hiroshima. What struck me most was the distance between us: having been born in the US, he had a very clear view, he was able to envision a film about Hiroshima; whereas I, born in Hiroshima, had nothing to say. When he asked me, "You were born there, what do you have to say about Hiroshima?", I couldn't come up with an answer. I wanted to film the difference in our outlooks, our points of view [ . . . ] what interested me was the "and" that I saw between Kramer and myself. (Tesson 2001, p. 70)

However, Kramer's death soon afterwards brought the project to a premature end. Suwa decided to develop the idea of conversation outlined above, where the role of interlocutor that was to have been played by Kramer would be taken by the film Hiroshima mon amour. Resnais had deployed strategies of mise en abyme in his film so as to address what Deleuze referred to as the "incommensurability" characteristic of the modern image as such: the impossibility that cuts might create rational connections between shots. In Deleuze's words, "The interval is set free, the interstice becomes irreducible and stands on its own" (Deleuze 1989, p. 277). Such incommensurability also emerges between the "internal" life of the film and the "external" reality of the bombing of Hiroshima: the horror of the real event is so awful as to lie beyond narration. Duras wrote her script on the premise that Hiroshima could not be addressed. The film draws on various levels of reality that move the mechanics of its own fiction into a play of meanings: Hiroshima features as a documentary image; as the diegetic frame to the love story between a French woman (called simple Elle [She]) and a Japanese man (Lui [Him]) which drives the plot; and as a fiction within his work of fiction: Elle is an actress playing a part in a film shoot about the bombing. This threefold interrelationship sets up a hall of mirrors effect which in turn highlights the incommensurable "cuts" between them.

Suwa saw the subject of $H$ Story in the same way as Duras had before him: the impossibility of speaking about Hiroshima (Tesson 2001, p. 71). Thus, Suwa's film replicates and amplifies the levels of mise en abyme in Hiroshima mon amour by referring directly to them. The surface story comprises the endeavor to remake Resnais's movie, which — at the same time-is part of its structure as a fiction. Without changing a single word, Suwa puts Duras's script to the test, knowing that the project is doomed to failure, and roots his film in the fake 'making of' sequences and the scenes shot with Béatrice Dalle and Hiroaki Umano (in the roles originally played by Emmanuelle Riva and Eiji Okada, Elle and Lui), to which he adds archive footage and a digression in the film's second half into the love affair that arises between Dalle and the Japanese writer Kou Machida, the main supporting actor in the remake. The levels of reality multiply in relation to Resnais's film: the story within a story is -in Hiroshima mon amour the making of another movie-in H Story, the making of Hiroshima mon amour itself. At the 
same time, however, the film within a film is split between the script written by Duras, which is quoted word for word, and the shots of Dalle and Umano which allude indirectly to the scenes shot by Resnais. There is only one explicit visual quotation after the film's opening sequence, in which Dalle and Umano re-play the first scene in Hiroshima mon amour. The final frame is a medium shot of the lovers in bed (Figure 1a), an image that fades to black, followed by a shout of "Cut" and the sound of the director giving his orders. The black screen brightens to a still image from Hiroshima mon amour in which Riva and Okada are seen in a similar pose to the figures in the previous frame (Figure 1b).

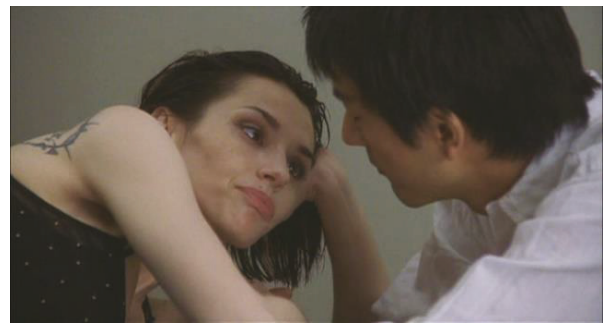

(a)

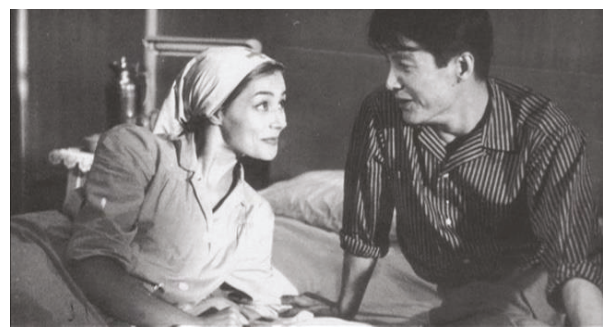

(b)

Figure 1. Frame (a) from H Story showing actors Béatrice Dalle and Hiroaki Umano representing a scene of Hiroshima mon amour, followed by a frame of the film (b) showing a photography of the original scene played by Emmanuelle Riva and Eiji Okada. Source: DVD edition by Cinéma Indépendant (France).

The depiction of both frames can even suggest a continuation between them, as Figure $1 \mathrm{~b}$ is a wider frame of the same disposition presented in Figure 1a. However, the differences on the actors and the nature of both images (film versus photography) evince that it is a false continuation. This can be read as the first mark of resistance that Suwa puts against Hiroshima mon amour. It is followed by a conversation segment between Suwa and Machida styled as part of the 'making of' depiction of the creative process. Thus, Resnais's film features as a deferred echo, a fixed (photographic) image that underscores the impossibility of the kind of mimesis proposed by the film's opening sequence. This split play of meanings redoubles as the film unfolds, since " $H$ Story is not an exact copy of Hiroshima mon amour, a tracing of it. Rather, it is one of the possible expressions produced by Hiroshima mon amour when the latter is apprehended as an abstract diagram, as an individuated entity which is built according to a principle of immanent multiplicity" (Hainge 2008, p. 166).

Thus, a range of meanings branch out from the "impossibility of talking about Hiroshima", which may be referred to as the "discourse of Hiroshima", as distinct from the "reality of Hiroshima". In its own time, Hiroshima mon amour was a film that endeavored to address the "epistemological crisis brought on by those events of the twentieth century which exceed comprehension" (Hainge 2008, p. 163); but over time, it has become an inescapable frame of reference for the "discourse of Hiroshima", despite Resnais's original refusal to undertake a documentary reconstruction of events: "While Hiroshima mon amour rejected the possibility of reconstruction, in its own time, [H Story] sets up, between itself and the world, the place of the other, the place in which an other is constructed in audiovisual terms, forcing the viewer to see and acknowledge, within this inter-filmic experience itself, the point-a point that he himself must determine-from which he views" (Grange 2011, pp. 180-81). What makes the point of view that Suwa obliges the viewer to take up such a slippery position is his use of Resnais's film both as the ground for his own work and as a framework that enables the proliferation of meaning. The first part of $H$ Story, from the very opening sequence outlined above, calls into question not merely the possibility of representing the horror of what happened in Hiroshima, but of representing a text which itself discusses that same impossibility. In contrast to the Suwa-character's determination to continue the shoot, Dalle embodies the growing crisis around the possibility of representation as such. In the opening scene, Dalle is able to recite her 
lines without fault or falter; later, the actress-character becomes more and more forgetful of Duras's script, before finally deciding that the effort to remember it is a stupid waste of time.

Dalle confirms what the referential images cited by Suwa have foreshadowed: the absurdity of his cinematic enterprise. So H Story ends up moving away from its early mix of mocked-up 'making of' and intertextualization to tell a new story by digressing from the earlier one. The shift in $H$ Story is marked by the scene in which the crew try to film the meeting of Elle and Lui in a bar in Hiroshima mon amour. In Resnais's film, the scene blurred the temporal lines between the present time of the movie and Elle's reminiscences of her love affair with a German soldier during the Second World War. The shifts in time merge through a degree of sound continuity and Lui's performance of both his own self and the 'reincarnation' of the dead German soldier. A sentence spoken by Elle prefaces one of the flashbacks: "C'est horrible. Je commence à moins bien me souvenir de toi". This is the exact sentence that Dalle is unable to remember in the remake of the scene. Her inability to recall (to re-present) the expression of a memory undermines the temporal sleight of hand performed by Resnais. The shift in time is replaced by an act of flight. Dalle leaves the bar-that is, the space of memory in Hiroshima mon amour shaped by temporal discontinuity — and smokes outside the door with Machida, the writer, who until then had been only an observer of the film shoot.

Several intra-filmic elements set up these intertextual relationships. The river Ota, along whose bank Machida and Dalle stroll following the latter's flight from the bar (Figure 2c) is a vague vessel of meaning indicated verbally: in an earlier scene, Umano had told Dalle that many of the people of Hiroshima died having drunk contaminated water from the river after the bombing. In Hiroshima mon amour, the meanings associated with the river are broader. It appears just before the scene in the bar, when the viewer is presented with a sequence of shots showing the everyday life of ordinary people along the banks of the river (Figure 2a). However, it is also an ongoing feature of the background to the scene in the bar, through the window or the reflection of the lights on its waters that are reflected back inside. Moreover, in Elle's flashbacks during this scene, she recalls her encounters with the German soldier on the banks of the river Loire in Nevers (France), in such a way that the presence of the river prompts associations with the bar setting as well as with the world beyond it. The place is given the simple name "Tea Room Dōmu" in Hiroshima mon amour (Figure 2b), whereas in H Story no title appears until Dalle flees the set of the shoot and Machida goes after her, when the sign above the bar door takes on an ironic tone: under a sign saying "French-Japanese" (Figure 2d), two characters, the French woman Dalle and the Japanese man Machida, neither of whom speaks anything other than their own language, have a conversation. Suwa appropriates signs presented in Resnais's film so as to re-present them with new meanings. In the case of the river, the scene and setting it frames are the same, but a new meaning is generated through this approach to imitation.

Following this first failed attempt, Suwa sets out to re-shoot the same scene in the bar the next day. In an unscripted moment, Machida enters the scene at Suwa's request, in an apparent reprise of the role played by an unknown Japanese man who approaches Elle in one of the final scenes in Hiroshima mon amour. As in other scenes, the sound of a clapperboard marks the shift from the fake 'making of' to the re-make shoot of Hiroshima mon amour. The shot is held for around four minutes. Dalle is the first to enter the scene, emerging from the back of the frame. She sits at a table to the right and orders a drink, peering into the darkness of the setting around her until she sees a reddish light seeping in under the door at the back of the bar through which she had entered (Figure 3a). Umano comes through the same door and sits at a table farther away from the camera, near the center of the frame (Figure 3b). The two characters glance at one another, but they do not make full eye contact. Before they can make a real connection, Machida breaks into the scene, occupying the empty space at frame-left (Figure 3c), making his way towards Dalle's table, where he sits down and stares at her (Figure 3d). 


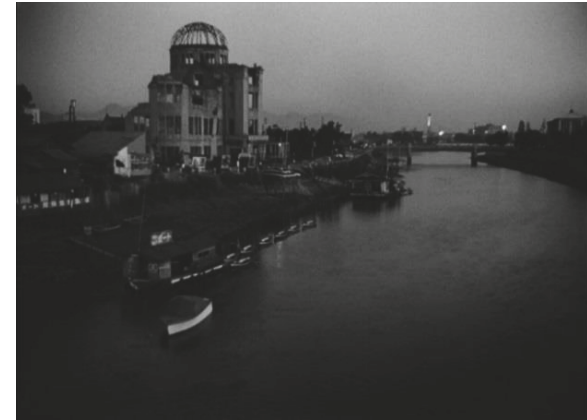

(a)

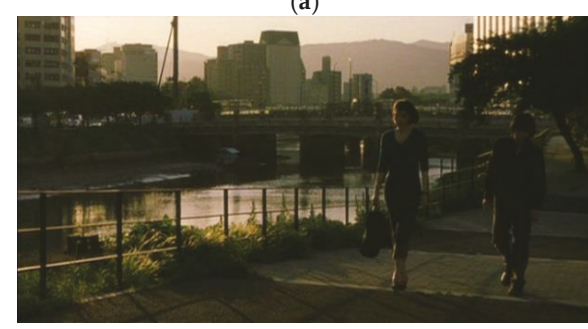

(c)

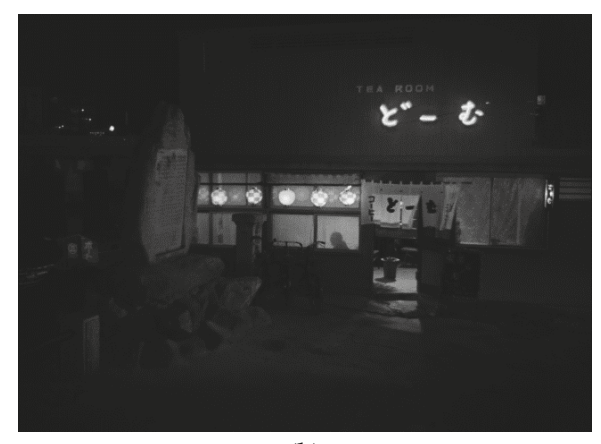

(b)

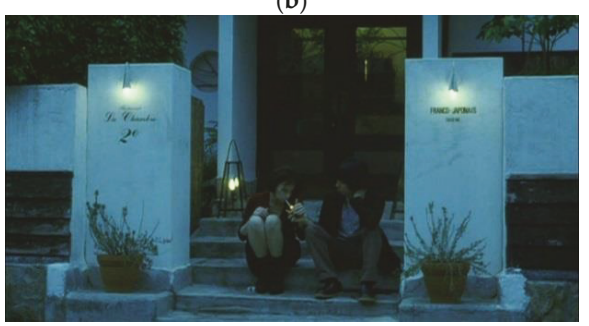

(d)

Figure 2. Frames showing similar sets in Hiroshima mon amour and H Story: the Ota River $(\mathbf{a}, \mathbf{c})$ and the restaurants $(\mathbf{b}, \mathbf{d})$ where a key scene takes place in both films. Source: DVD editions by Acontracorriente (Spain) and Cinéma Indépendant (France).

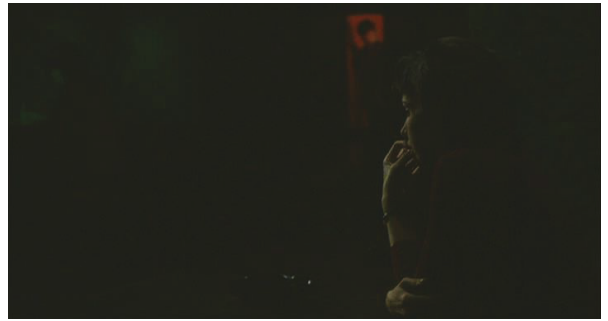

(a)

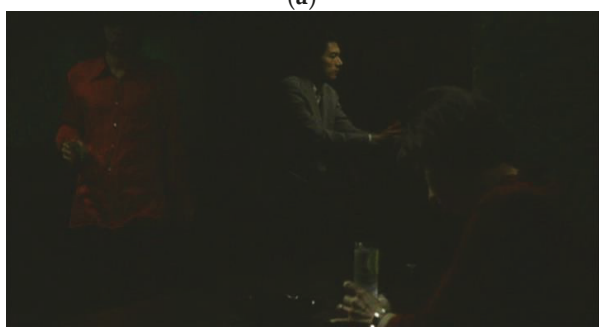

(c)

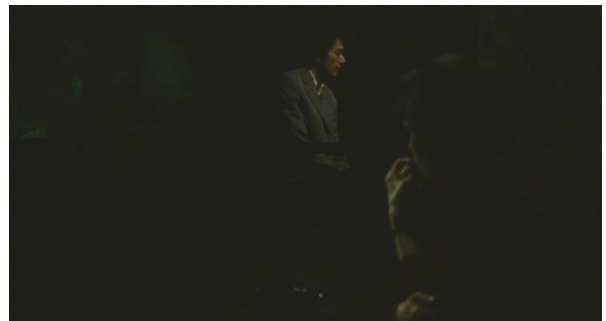

(b)

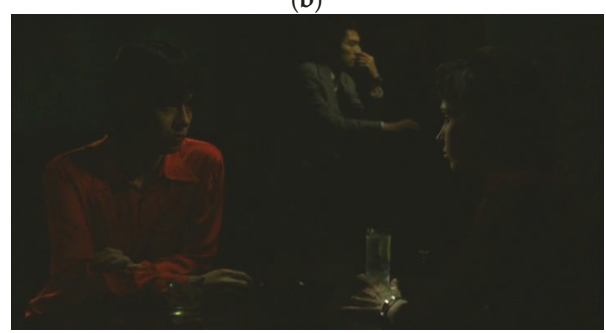

(d)

Figure 3. Four frames from $H$ Story taken of a unique static shot showing the entrance of actors Hiroaki Umano (a,b) and Kou Machida (c,d) changing the dynamic of attractions around the main character played by Béatrice Dalle (at the right of the images). Source: DVD edition by Cinéma Indépendant (France). 
Tracking the dynamic of his gaze, the camera turns slowly through $90^{\circ}$ on its axis, coming to rest on an almost face-on shot of Dalle, who is still looking at Machida. The camera movement and the play of colors (the reds of Machida's shirt and the weak light leaking in from outside disrupt the languid greens that have colored the scenes in the bar thus far) underscore the shifting attractions at the heart of the film: Machida, an accidental actor, a member of the cast of the mocked-up 'making of' not the remake, steals the scene by neutralizing the chemistry between Dalle and Umano, the supposedly lead romantic couple. What was to have been a re-shot scene from Hiroshima mon amour becomes a long wordless shot from which the story of H Story itself surfaces. Is the silence of the scene due to Dalle's failure to remember her lines? Why does Suwa not cut the shot, given that the scene ought to contain dialogue? One interpretation of this innermost level of reality in H Story (the movie being shot within the fake 'making of' that comprises Suwa's film) suggests that this change affects the other, outer levels: given that the most basic memory has failed (in Dalle), the words of the script for Hiroshima mon amour, none of the other memories represented in Resnais's film may be enacted here; and, as a result, the re-make itself is cut short.

Suwa shoots another attempt to film a scene from Hiroshima mon amour, the scene in which the leading characters bid farewell to one another. This is followed by two brief, silent sequences: Dalle walks along a street in Hiroshima, before running into Machida in another bar, a scene that bears a closer formal resemblance to the scene between Elle and the unknown Japanese man in Hiroshima mon amour. Here; however, there is no indication that this is a filmed scene-no sound of the clapperboard, no noise of crew members issuing orders-and it ends as abruptly as it began. Immediately after, Suwa appears in a mocked-up 'making of' sequence in which he is seen taking the decision to call time on the shoot. Thus, this second scene in a bar between Dalle and Machida marks a moment of crisis across the levels of reality in H Story: the scene is, or may be, at one and the same time, part of a remake of Hiroshima mon amour, part of the 'making of' of a remake of Hiroshima mon amour, and/or part of a film called $H$ Story edited together from the rushes of a 'making of' of a remake of Hiroshima mon amour. The echo of the original fades, but not wholly to black or to silence. In the end, Suwa frames his film around two contrary sources of power: Duras's script and the desire to escape embodied by Dalle in H Story. To quote Suwa himself, "In H Story, the reality named Béatrice resists (hi)story" (Burdeau 2006, p. 90). Dalle's forgetfulness subverts the text; her desire diverts the plot of the love story; and her new-found freedom seems to wrest control of the images that comprise the film.

Several details illustrate Dalle's embodiment of control in the film. Near the beginning of the film she refers to the opening scripted by Duras as "problematic": "There was archive footage," she says, to which Suwa replies, "We have none of that kind of thing." The film later contradicts its own director when, after one of her several flights from the shoot, a shot of Dalle drinking alone (Figure 4a) is followed by a sequence of archive images (windows, a sluicegate, rusty scaffolding) that gesture towards the destruction wrought by the bomb. Once again, this move both is and is not a departure: "ownership" of these images is attributed to Dalle on the basis of her desire to include archive footage and through the way the scene is edited together, but at the same time their inclusion is an echo of Hiroshima mon amour. In Resnais's film, Elle's recollections were shaped in line with a similar formal strategy: the shots of Emmanuelle Riva drinking are followed by images of her memories of Nevers (that is, the juxtaposition of the protagonist in the primary frame with shots from a different time-frame implies the latter belongs to the former). At the same time, however, Dalle's investment in these images does not mean that they are wholly hers: the fleeting frame-detail of an old American clapperboard (Figure $4 \mathrm{~b}$ ), an instant in the archive footage, likewise implies that they pertain to the remake, by recalling the sound of clapperboard Suwa uses in H Story to punctuate the cuts in the fake 'making of' sequences. Thus, the elusive temporality of Hiroshima mon amour becomes an elusive ownership of memory in H Story. 


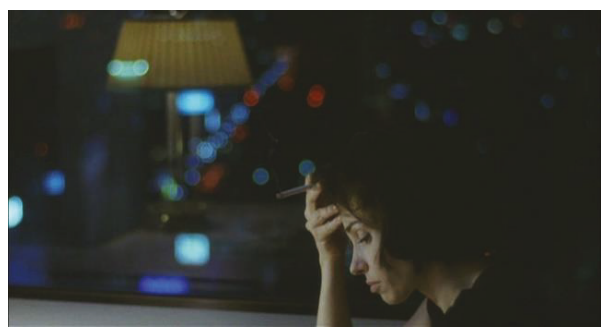

(a)

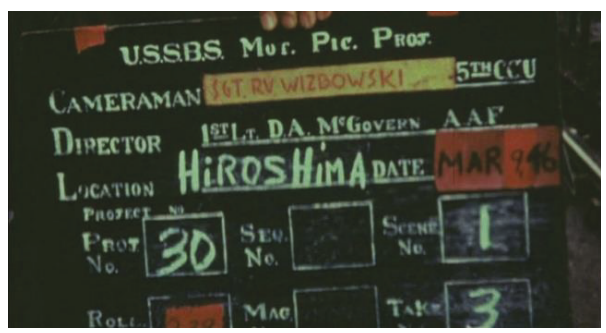

(b)

Figure 4. Frames from H Story. A shot of Béatrice Dalle drinking alone (a) is followed by a sequence of archive images from the Hiroshima bombings (b). Source: DVD edition by Cinéma Indépendant (France).

Archive images reappear in $H$ Story for a second time towards the end of the film, when the decision to close down the shoot has been taken. In this instance, the images do explicitly reference the bombing of Hiroshima: they comprise a panoramic view of the ruins of the recently bombed city (Figure 5a). The scene is followed by a shot of Dalle and Machida walking along various streets in the city (Figure $5 b$ ), where it is clear that their walk is separate from the remake and the mocked-up 'making of'. What has happened before this sequence of shots? Through his complex mise en abyme, Suwa has called into question the very possibility of drafting a fiction around Hiroshima. Neither Hiroshima mon amour nor his projected remake can be anything more than a fixed part (literally, a still image) of the "discourse of Hiroshima", which amounts to a further barrier between the actual events (the bombing of the city) and the present.

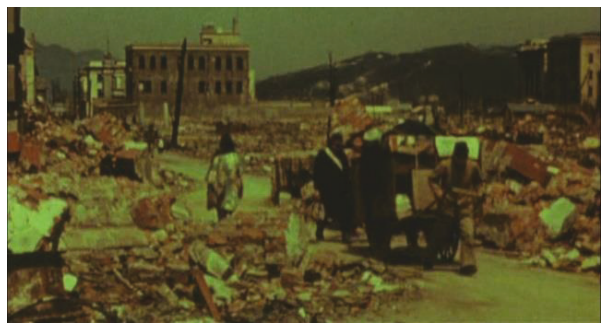

(a)

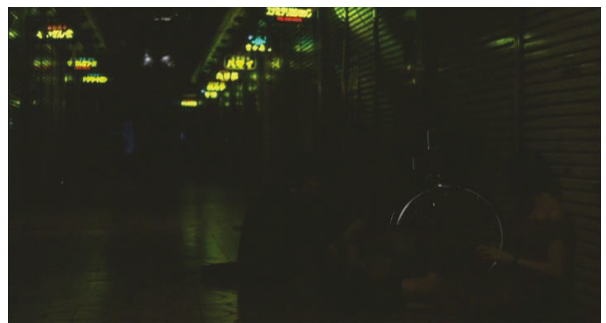

(b)

Figure 5. Frames from $H$ Story. A panoramic view of the ruins of the recently bombed Hiroshima (a) followed by a shot of Dalle and Machida walking along the city in present (b). Source: DVD edition by Cinéma Indépendant (France).

When at last the historical past and the cinematic present are (re)presented in their "pure" form, by means of direct archive footage and an image of the present abstracted from the fictional narrative, the relationship can do nothing other than reflect the unbridgeable distance between them. The past exists as a play of echoes and shadows that tell a new story in the present Hiroshima through which Dalle and Machida move (Verevis 2012, p. 172): their autonomy as a story is effected only through the experience and subsequent flight from such echoes (Duras's script, the museum about the bombing that both visit halfway through the movie). This endorsement of the opening present circles back to the starting point ("It is impossible to talk about Hiroshima") and discloses what Suwa envisions as the heart of his film:

Within the film, the present marks the point when the past becomes the future. This present is in the middle of a story that is History itself. I think that H Story is film in search of a present moment capable of escaping both the past and the future. (Burdeau 2006, p. 90) 


\section{Reconstruction: A Perfect Couple}

Following his experience as a co-producer of H Story, Suwa went on to further his career as a transnational filmmaker by undertaking his first project in Europe. A Perfect Couple was an Arte France initiative with secondary support from a Japanese enterprise (it was coproduced by the company Bitter End), filmed in French on location in Paris. For Suwa, the film also marked a return to the subject-matter and themes of his first two feature-length productions: the couple in crisis. The move from $H$ Story to A Perfect Couple seems to have been a logical one:

Assuming that Hiroshima mon amour (1959) walks the blurred line between fiction and cinematic essay, between literary construct and documentary, between the present time and the time of memory, we may conclude that the film suggests a reading whose scope ranges beyond its historical moment and whose vestiges may be traced to contemporary cinema. Suwa's attempt at an impossible remake leads inevitably to the aesthetic achievements accomplished in A Perfect Couple. (Quintana 2007, p. 54)

Not only is H Story the most explicit account of Suwa's engagement with European modernism, it is also the film that most fully deconstructs his attachment to modernist formal strategies, which according to Quintana involve, "heavily weighting the significance of the frame, the surfaces and volumes that arise within the image, the sounds that cross the visual space and signal certain positions beyond the limits of the space" (Quintana 2007, p. 56), issues that stem from a fundamental rejection of the mode of editing. In A Perfect Couple, comprising only about forty shots in total, Suwa continues his exploration of modernist formal techniques by setting his work in intertextual dialogue with one of the films that had done most to canonize them: Journey to Italy, the cornerstone of European cinematic modernism in both theory and practice.

The intertextual relationship between Journey to Italy and A Perfect Couple is one of allusion; in this instance, Suwa's work is not structured via the disruption of levels of time, space or reality. The main parallels comprise similarities in plot development. Suwa's film also tells the story of a couple who, after a long relationship, are thrown into a crisis that is intensified by a journey: Marie (Valeria Bruni Tedeschi) and Nicolas (Bruno Todeschini) travel from Lisbon to Paris (a city they had left a long time before) to attend the wedding of one of their best friends. The shifts in the story between the arguments shot in interior (the same gloomy hotel room) and the separate escapades of both spouses, as well as the 'miraculous' reconciliation at the end, clearly recall Journey to Italy, as do the kind of escapades each engages in: like the character of George Sanders, Nicolas flirts with the possibility of a fleeting love affair, while Marie, like Ingrid Bergman, endeavors to escape herself by contemplating sculptures (the Rodin Museum in Paris takes the place of the National Archeological Museum in Naples). Suwa himself has acknowledged his deliberate purpose to set A Perfect Couple and Rosellini's film in conversation with one another, especially in developing the character played by Bruni Tedeschi; however, he also noted a key difference to H Story: "A Perfect Couple is not a film that presents resistance to a (hi)story" (Burdeau 2006, p. 90).

An exploration of the meanings that accrue to the statues in the scenes played out by Marie in her visit to the Rodin Museum, in comparison to the parallel experiences of Catherine (the character played by Ingrid Bergman in Journey to Italy) at the National Archeological Museum in Naples, discloses the aesthetic discoveries Suwa made through the practice of intertextualization. In Catherine's first such scene, her engagement with the statues comprises, above all, a present encounter with the past. Following the anodyne commentary of the museum guide, the camera movement implies a continuum of experience between Catherine and the statues by panning along the faces of some of them, before coming to a stop on the main figures: a shared emotional present is generated between the art-works and the character. Subsequent frames are close-ups of the statues' faces, presented from Catherine's subjective viewpoint: the first tracking shot that closes in on a discus thrower whose painted eyes appear to stare directly into the camera lens (Figure 6a) is preceded by a similar camera movement that indicates where Catherine's view is directed (Figure 6b). In the next scene, Catherine herself puts 
her experience into words: "To think that those men lived thousands of years ago ... And you feel like they're just like the men of today. It is as if Nero or Caracalla, Caesar or Tiberius would suddenly tell you what they felt". In marked contrast to the "ascetic" experience described in the poems written by a former lover that had prompted her visit to the museum, Catherine's encounter with the statues is a very earthly experience.

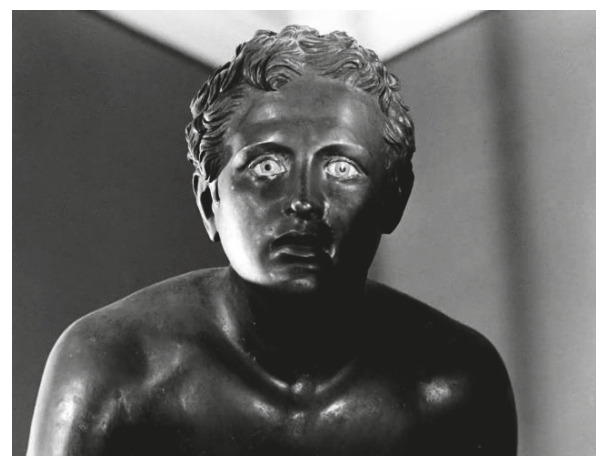

(a)

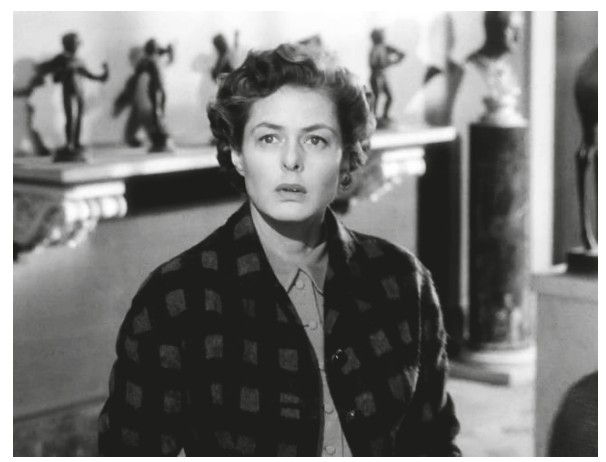

(b)

Figure 6. Frames from Journey to Italy. A tracking shot that closes in on a discus thrower whose painted eyes appear to stare directly into the camera lens (a), preceded by a similar camera movement that indicates where Ingrid Bergman view is directed (b). Source: Blu-Ray edition by The Criterion Collection (USA).

In her perception of Rodin's statues, Marie sees a reflection of her experience of married life. The size of the joined hands (Mains jointes), the nude study of a man worshipping his wife (L'eternelle idole) and an unfinished Eve (Eve) tell of the progress of passion from first love to motherhood, to the final step when the guide's comments redefine Eve by stripping her of her mythic aura: the statue was modelled on a young woman, and was left unfinished when Rodin learned that she was pregnant. Marie's self-projection onto the meanings of the statues takes the place of the dialogue enacted by Catherine. As Neyrat (2006, p. 13) avers, the lines by Rilke about the L'eternelle idole quoted by the museum guide in this scene ("Something of the mood of a purgatory lives in this work. A heaven is near, but not yet attained; a hell is near, and not yet forgotten") may well encapsulate the situation in which the film's protagonists find themselves: a kind of purgatory (the dim interior of their hotel room) that may lead to either separation or reconciliation. The shot of L'eternelle idole depicts the connection between Marie and the statues in an explicit way: the sculpture is shown through its glass case, in whose surface Marie's reflection is clearly seen (Figure 7a). The play of reflections is amplified by a mirror located behind the statue, leading to a confused profusion of images: the image itself, its reflection in the glass case and its reflection in the mirror. In contrast to the direct, close-up shot of Catherine before the statue of the discus thrower, Suwa decides to represent visually the dispersive fragmentation of possible meanings around the statues. At the same time, however, Suwa does also draw on the direct shot of his main character to represent her personal experience of the art-works (Figure 7b). However, a strategy that is worked more subtly in Rosellini's hands takes on a much more cutting form in the representation of Marie's interior life. First, because the close-up is used only very exceptionally in a film structured though long, wide shots; and second, because her facial features are presented in a stylized way: the shot is long, filmed with a handheld camera (unlike the rest of the film, shot with a fixed camera) and tracks more intensely on Marie's face, who weeps as she contemplates the statue of Eve. 


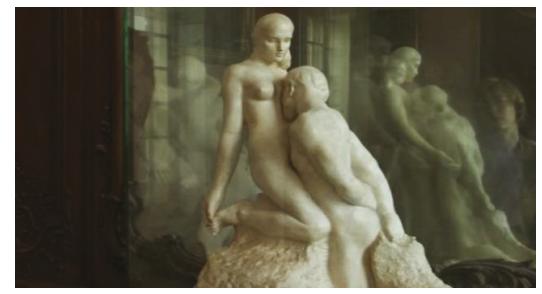

(a)

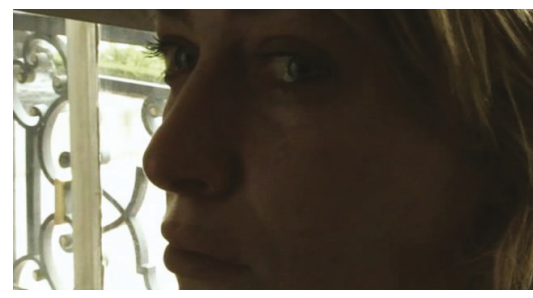

(b)

Figure 7. Frames from A Perfect Couple. A shot of Rodin's L'eternelle idole in which the sculpture is shown through its glass case, in whose surface Valeria Bruni Tedeschi's reflection is clearly seen (a), and an extreme close-up that represents her personal experience of the art-works (b). Source: DVD edition by Intermedio (Spain).

In a later scene, Marie is shown trying to explain her encounter with the statues to her husband. In contrast to Catherine's decision not to refer to the poems written by her former lover to account for her experience, Marie sets out to read aloud to Nicolas from a poem by Rilke about Rodin. Although Marie's personal investment in the visit to the museum has run deeper within her, what she discovers through that experience leads to a development of her character that mirrors Catherine's: the sense of thwarted motherhood. The story about the pregnant model for the statue of Eve, which seems to be the reason Marie weeps in the close-up on her tears, echoes a series of subtle signs about motherhood with which Suwa has seeded his film, leading to the revelation of Marie's unfulfilled desire to be a mother.

A similar story is told about Catherine and revealed in her wanderings (the number of pregnant women she sees on the streets of Naples, for instance). In both Journey to Italy and A Perfect Couple, these sub-plots concerning hidden desire lead to a second encounter with sculptures on each main character's part. In Journey to Italy, the second experience takes place at the site of the excavations in Pompeii rather than the National Archeological Museum in Naples. Catherine witnesses the discovery of the traces of two bodies from the Roman period which had been buried under the lava of Vesuvius. This sculpture is made in the real time of its discovery. The archeologists make a set of holes in the fossilized lava, into the space shaped by the bodies of the dead before they decomposed, which they then fill with plaster. The dried plaster takes the form and position of the bodies at the time of their death. When the archeologists dig out the plaster-sculpture, they discover it represents a couple: "Probably husband and wife. They died together," says one of the archeologists. Rosellini shows the recently revealed plaster statue (Figure 8a), followed by a counter shot-a framed medium shot—of Catherine, her husband and the archaeologist looking at it (Figure 8b). She abruptly exits the scene, weeping at the sight of the sculpture. Rosellini included her reaction, within the same scene, counterpointed by the calm with which the two men contemplate the discovery.

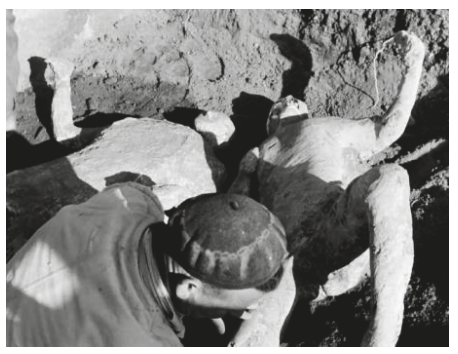

(a)

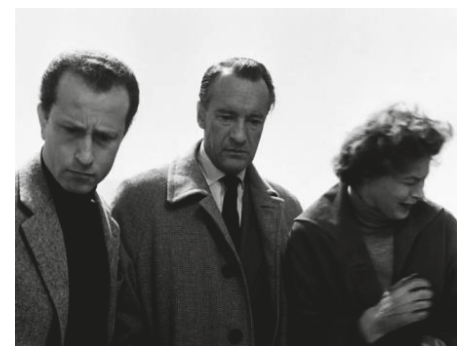

(b)

Figure 8. Frames from Journey to Italy. A revealed plaster statue representing a man and a woman who died in Pompeii (a), followed by a counter shot of the three characters looking at it (b). Source: Blu-Ray edition by The Criterion Collection (USA). 
In this regard, Catherine's reaction to the sculpture uncovered at Pompeii mirrors Marie's experience in the museum more closely; the sudden cry of grief is not a shared experiential present with the statue: it is a deeply personal moment unleashed within the character. Catherine's doomed marriage and unfulfilled desire to be a mother are laid bare by the discovery of the statue. Like Rodin's L'eternelle idole, the statue at Pompeii may be read as an exalted epitome of the act of love. At the same time, however, as with the statue of Eve, unexpected life events (pregnancy, death) may be traced in the material imperfection of the art-works (Rodin's sculpture is unfinished, the Pompeii statue is cast from plaster). The unlikely combination of the exalted and the accidental prompts a visceral reaction in both Catherine and Marie. The mirroring of meanings between the two scenes is underscored by the scene in which Marie encounters the statutes again, on a second visit to the Rodin Museum. On this occasion, the sculptural is transcended by the real: while looking at the statue of Eve, Marie meets a former boyfriend from high school, who is visiting the museum with his son. Suwa repeats the sequence of shots: a general shot of Marie contemplating the statue is followed by a tight close-up of her face from a hand-held camera, as the conversation with her former boyfriend begins (Figure 9a). Their conversation extends into a wide shot that encompasses Marie, the man and his son (Figure 9b). They reminisce with one another until the man reveals that his wife, the boy's mother, had died years before. Marie is deeply moved by this revelation, just as she was by her contemplation of the statue of Eve earlier. This further sign of her own frustrated desire to be a mother is intensified by the sense of a loving union—an apparently loving marriage—cut short by the woman's death.

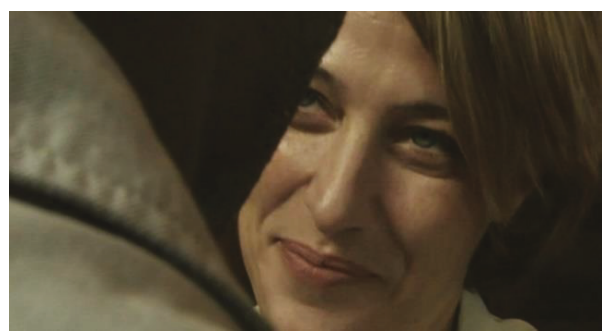

(a)

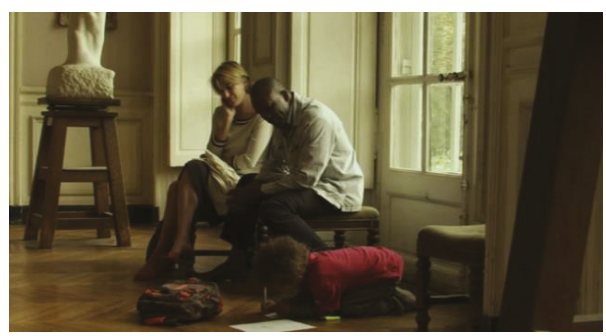

(b)

Figure 9. Frames from A Perfect Couple. A tight close-up of Valeria Bruni Tedeschi's face from a hand-held camera (a), followed by a wide shot that encompasses her whole conversation (b). Source: DVD edition by Intermedio (Spain).

The story told in the Rodin Museum parallels the experience of the plaster statue in Journey to Italy. In both films the sculpture motif is carried across two scenes: in the first, creating a moment of shock, before moving on, in the second, to yield an epiphany. Suwa illustrates this progression in more visual terms: while the tight close-up was the climax of the first scene set in the museum, it is deployed in the second scene just before the moment when Marie catches sight of the man and his son. The first, climactic close-up creates a greater emotional impact; whereas the effect of the second close-up is more intimate and calmer. The exact meaning of Catherine's reaction to the plaster statue and Marie's response to seeing the man and his son remains unexplained (beyond a general idea of the desire for fulfilled love and motherhood), but it is clear that they set up the common ending to their respective stories, both of which come to a close on a miraculous reconciliation with their husbands. These endings are miraculous in that no logical line can be drawn from the external moments of revelation shown on screen and the reaffirmation of love at the end. The cut from one instant to the next is, once more, incommensurable.

\section{Conclusions}

The mise en abyme evinced in H Story is shaped by its intertextual relationship with Hiroshima mon amour via a series of direct references. The several levels of this mise en abyme mirror the 
corresponding levels in Resnais's film, which in turn render the earlier work itself a further layer in the film-within-a-film. By contrast, the intertextual relationship between A Perfect Couple and Journey to Italy is generated through allusion. Rosellini's original move towards mise en abyme comprises a reconfiguration of the meaning of the story by drawing a preceding narrative articulated by the statues into the diegetic frame of his work. Suwa replicates this strategy through the similarity in motif (the statues), the meanings that accrue to it (human love and motherhood) and the outline of the plot; at the same time, Suwa strips away the stylistic features Rosellini favors (he does not use the shot/counter-shot approach, instead tending towards the long fixed shot which highlights the vastness of the frame) and pushes the bounds of the representational power of the images he uses (Suwa uses other devices such as the play of reflections and mirrors in several shots, in addition to the mise en abyme enacted by the sculptures). Not only does Suwa's act of deconstruction in $H$ Story evince how far Hiroshima lies beyond representation, but it also identifies the formal strategies deployed in Hiroshima mon amour to assert its aesthetic reality. A film like A Perfect Couple springs from a similar assertion, the realization of such formal goals. Suwa lays no claim to the national sovereignty of particular discourses (envisioning Hiroshima from the perspective of Japan, for instance); his aim seems be to enter a pure, European-centered cinematic tradition so as to apply its formal achievements in even more stringent ways. Thus, Suwa's break through European borders by extending and radicalizing the forms of its cinematographic modernism seems no more than an accidental side-effect of his close belonging to the European way of framing cinema.

Funding: This research received no external funding.

Acknowledgments: This research was made possible with the support of the Department of Audiovisual Culture and Communication and the Friends Association of the University of Navarra.

Conflicts of Interest: The author declares no conflict of interest.

\section{References}

Armes, Roy. 1968. The Cinema of Alain Resnais. London: Zwemmer.

Bazin, André. 2005. What Is Cinema? Berkeley: University of California Press.

Burdeau, Emmanuel. 2006. Nobuhiro Suwa: "Mes Films Ne Cherchent Pas À Conclure". Cahiers Du Cinéma 610: 87-90.

Dällenbach, Lucien. 1989. The Mirror in the Text. Chicago: University of Chicago Press.

Daney, Serge. 1983. La Rampe. Cahier Critique 1970-1982. Paris: Cahiers du cinéma/Gallimard.

Deleuze, Gilles. 1989. Cinema 2. The Time-Image. Minneapolis: University of Minnesota Press.

Font, Domènec. 2012. Cuerpo a Cuerpo: Radiografías Del Cine Contemporáneo. Barcelona: Galaxia Gutenberg.

Fraga, Xesús. 2018. Nobuhiro Suwa: Las Imágenes Son La Huella de Lo Real Pero, Al Mismo Tiempo, Son Ilusiones. La Voz de Galicia, April 25. Available online: https:/ / www.lavozdegalicia.es/noticia/cultura/ 2018/04/25/imagenes-huella-real-tiempo-ilusiones/0003_201804G25P32991.htm (accessed on 15 July 2018).

Genette, Gérard. 1997. Palimpsests. Literature in the Second Degree. Lincoln: University of Nebraska Press.

Grange, Marie-Françoise. 2011. Le Film Pour Mémoire: Sur H Story (Nobuhiro Suwa, 2000). Cinemas-Revue d'Études Cinematographiques/Journal of Film Studies 21: 171-83. [CrossRef]

Hainge, Greg. 2008. A Tale of (at Least) Two Hiroshimas: Nobuhiro Suwa's H Story and Alain Resnais's Hiroshima Mon Amour. Contemporary French Civilization 32: 147-173. [CrossRef]

Joyard, Olivier. 2001. Le Printemps À Hiroshima. Cahiers Du Cinéma 561: 68-70.

Neyrat, Cyril. 2006. Marie et Les Statues. Cahiers Du Cinéma 609: 12-14.

Quintana, Àngel. 2007. La Modernidad Europea En El Cine Asiático: Reflexiones Sobre Una Migración Estética. In Derivas Del Cine Europeo Contemporáneo. Edited by Domènec Font and Carlos Losilla. Valencia: Ediciones de la Filmoteca, pp. 53-68.

Rivette, Jacques. 1955. Lettre Sur Rossellini. Cahiers Du Cinéma 46: 14-24.

Stam, Robert, Robert Burgoyne, and Sandy Flitterman-Lewis. 2005. New Vocabularies in Film Semiotics. Structuralism, Post-Structuralism and Beyond. London and New York: Routledge. 
Arts 2018, 7, 57

Tesson, Charles. 2001. Rencontre/Nobuhiro Suwa. Cahiers Du Cinéma 561: 70-72.

Verevis, Constantine. 2012. A Personal Matter: H Story. In Film Remakes, Adaptations and Fan Productions. London: Palgrave Macmillan, pp. 159-175.

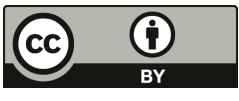

(C) 2018 by the author. Licensee MDPI, Basel, Switzerland. This article is an open access article distributed under the terms and conditions of the Creative Commons Attribution (CC BY) license (http:/ / creativecommons.org/licenses/by/4.0/). 


\title{
Naomi Kawase's "Cinema of Place"
}

\section{Erin Schoneveld}

Department of East Asian Languages and Cultures and Visual Studies, Haverford College, Haverford, PA 19041, USA; eschonevel@haverford.edu

Received: 13 February 2019; Accepted: 22 March 2019; Published: 28 March 2019

\begin{abstract}
This article evaluates contemporary filmmaker Naomi Kawase's (b. 1969-) status within Japan's film industry as well as her place among women directors. Using Kawase's three award winning features Suzaku (Moe no suzaku, 1997), Shara (Sharasōju, 2003), and Mogari (Mogari no mori, 2007) as the basis of my analysis, I examine the way in which these films illuminate the construction of Kawase's female authorship in relation to a specific location. While Kawase has made a number of critically and commercially successful films since 2007, I limit my discussion to her early narrative works set in Nara, Japan in order to illuminate the significance of the international film festival apparatus in establishing and upholding the discourse of auteurism in relation to regional identity. Through my analysis I argue that Kawase successfully negotiates this discourse through a strategy of self-promotion that emphasizes a "cinema of place" within the broader context of international film festivals such as Cannes. Kawase's "cinema of place" ultimately allows her to rearticulate the meaning of female authorship within an art cinema context by representing a new national cinema that challenges the structures and boundaries of Japan's studio system.
\end{abstract}

Keywords: Naomi Kawase; cinema of place; women directors; art cinema; international film festivals; female authorship; auteur

\section{Introduction}

I've got the potential to do it ... After Kurosawa and Ōshima, I think Kawase will be the next internationally known name among this generation [of Japanese filmmakers]. ${ }^{1}$

-Naomi Kawase

Naomi Kawase (b. 1969-) is regarded by many as Japan's leading female filmmaker, winning the Cannes Camera d'Or in 1997 for her debut feature length film Suzaku, the Cannes Grand Jury Prize for her second feature Shara in 2003, the Cannes Grand Prix in 2007 for her third feature Mogari no mori (The Mourning Forest), and the Carrosse d'Or prize in 2009 for lifetime achievement. ${ }^{2}$ While some critics maintain that Kawase tends to shy away from the media spotlight, it is clear that she is extremely aware of her public image as well as the conscious construction of her persona within national and international discourses of Japanese cinema. Kawase is not the first female film director to come out of Japan, however, she is considered one of the most successful and is on her way to becoming the most prolific. In the twelve years since her provocative statement Kawase has continued making films - both documentary and feature-with a body of work that totals thirty-eight to date. Most recently in October 2018, she was appointed to direct the official film of the 2020 Tokyo Olympic

1 Kawase made this statement at a June 2007 press conference in her native Nara, Japan when she announced the production of her film Nanayomachi (2008) and her intent to win the Cannes Palme d'Or (Schilling 2007b).

2 Kawase is the youngest-ever winner of the Cannes Camera d'Or for Suzaku (1997) and upon her return to Japan she became an instant celebrity. 
Games making her the fifth woman ever to oversee an official Olympic film. ${ }^{3}$ Yet, in spite of these successes, the question remains whether or not she will be the next internationally known name among this generation of Japanese filmmakers.

When it comes to the study of Japanese film, scholarship focusing on the role of Japanese female directors is still in its infancy. As Mitsuhiro Yoshimoto points out, since the 1960s Western scholarship on Japanese cinema has focused primarily upon three major modes of analysis: (1) the celebration of great male auteurs; (2) the formalist celebration of Japanese cinema as an alternative to classical Hollywood; and (3) a critical reexamination of the first two approaches through the discourse of "otherness" and cross-cultural analysis (Yoshimoto 2000, p. 8). While these approaches serve to frame the major discourses surrounding the development of Japanese cinema, they do little to illuminate the role of women, particularly regarding their contributions to and participation in national and world cinema cultures. Furthermore, these modes of analysis tend to eclipse important issues regarding cinema's production, distribution, exhibition, genre, audience, and reception.

At the 10th International Women's Film Festival in Seoul (April 2008), Louisa Wei highlighted some intriguing paradoxes in an attempt to assess the status of Japanese female directors and women's film of the past century. First, she noted that, during the early 1920s, women's film became an important genre even though the early masters of this genre were all male (Wei 2008, p. 58). Second, while Western feminist movements of the 1960s and 1970s sparked scholarly studies of the works of female directors, a critical gap remains in the systematic and in-depth analyses of these works (Ibid.). Unfortunately, Wei's observations-while over ten years old-still hold true. Despite the fact that the field of women's cinema is flourishing with a rigorous focus on the study of non-Western art and cinema cultures, there still remains no extended study of any female director in postwar Japanese cinema that has been critically examined within the larger context of Japan's cinematic history. ${ }^{4}$

Thus, the question of Kawase's status as a Japanese filmmaker within the international film festival context becomes all the more interesting, especially when trying to understand how her work is received in a culture where very few women directors have been actively promoted and recognized. In her book Women's Cinema, World Cinema Patricia White opines that " ... the few women who have risen to the top ranks of elite auteurs have cannily negotiated discourses of female exceptionality both in their personae and in their films" (White 2015, p. 22). Kawase's alignment with filmmakers such as Akira Kurosawa (1936-1993) and Nagisa Ōshima (1932-2013) clearly reveals an awareness of the way in which the global/western film industry-particularly within the space of international film festivals-continues to privilege the auteur model to create and market a national cinema culture.

Yet, Kawase's embrace of this model is also a strategic one in which she seeks to establish herself as a cineaste by promoting a specific brand of authorship within an art cinema context that simultaneously sets her on par with her male predecessors and avoids the potential for marginalization associated with discourses of women's cinema as counter cinema. As Timothy Corrigan has argued, "the romantic roots of auteurism need to be taken another step toward recontextualizing them within industrial and commercial trajectories (Corrigan 1991, p. 103)". Indeed, by embracing and asserting her agency over the auteur model—both critically and commercially—Kawase has succeeded in articulating a visual language that posits regionalism as a new form of nationalism through what I call a "cinema of place".

Using Kawase's three feature length films Suzaku (Moe no suzaku, 1997), Shara (Sharasōju, 2003), and Mogari (Mogari no mori, 2007) as the basis of my discussion, I will examine the way in which these early narrative works illuminate the construction of her auteur status in relation to a specific location.

3 Kawase follows in the footsteps of Caroline Rowland (London 2012), Gu Jun (Beijing 2008), Mai Zetterling (Munich 1972), and Leni Riefenstahl (Berlin 1936).

4 In the past twenty years the most notably scholarship devoted to Asian women's cinema has manifested itself in the form of Yoshida Mayumi's (Yoshida 2001) Josei kantoku eiga no zenbo = Films of the World Women Directors, Wada-Marciano's (2012) Japanese Cinema in the Digital Age as well as edited volumes such as Tanaka Kinuyo: Nation, Stardom and Female Subjectivity (González-López and Smith 2018) and Female Authorship and the Documentary Image (Ulfsdottoer and Rogers 2018; Nakane 2018). 
While Kawase has made a number of critically successful films since 2007, I have chosen to limit my analysis to her three award-winning works-all of which are set in Nara, Japan-in order to illuminate the significance of the international film festival apparatus in establishing and upholding the discourse of auteurism in relation to regional identity. ${ }^{5}$ Through my analysis I argue that Kawase has successfully negotiated this discourse through a strategy of self-promotion that emphasizes a "cinema of place" within the broader context of international film festivals such as Cannes. This ultimately allows her to rearticulate the meaning of female authorship by representing a new national cinema that challenges the structures and boundaries of Japan's studio system, conferring a new framework for the auteur as a mediator between the local and the universal.

\section{International Film Festivals}

The role of international film festivals during the immediate Postwar period was extremely critical to the rehabilitation of the Japanese film industry. Indeed, as Yoshiharu Tezuka argues, in the final years of the US Occupation of Japan (1945-1952) when Kurosawa's film Rashōmon, 1950 won the Golden Lion grand prize at the 1951 Venice Film Festival, "it signaled both Japan's return to the international community after the war, and triggered the internationalization of Japanese cinema" (Tezuka 2012, p. 3). Major film studios such as Daiei—who produced Rashōmon—swiftly took note of how international film festivals, much like the Olympic Games, provided opportunities for cultural diplomacy, as well as the reconstruction of Japan's international image, and, just two years later, Kenji Mizoguchi's Ugetsu Monogatari (Tales of the Silvery Moon, 1953) won the Silver Lion at Venice with Teinosuke Kinugasa's film Jigokumon (Gates of Hell, 1953) winning the Grand Prix at Cannes in 1954. During the post-World War two era, Cannes, Venice, and Berlin rose to the top as "A-festivals" with the power and prestige to anoint the next great cineaste. Cannes in particular became the "kingmaker of the festival circuit" establishing the auteur director model as the pinnacle of success (Elsaesser 2005, p. 91). Thus, the formula for many Japanese filmmakers working during the 1950s through 1970s began with the vetting process of winning an award at an international film festival and then parlaying this achievement into global box office recognition. Yet, these opportunities were primarily afforded to male directors and, before the mid-1980s, women received very little financial support from Japan's film industry and other cultural institutions with regard to promoting and distributing their work both at home and abroad (Wei 2011, p. 41). However, since 1985, one of the major forces behind the promotion of Japanese female directors has been the Tokyo International Women's Film Festival. Held bi-annually from 1985 to 1991 and annually, thereafter, the Tokyo International Women's Film Festival is one of Asia's most competitive festivals and, like its European counterparts, has become an important platform for promoting independent films as well as validating the reputation of its director as a potential auteur. Since its establishment, the Tokyo International Women's Film Festival has provided women filmmakers with a greater number of opportunities to direct and showcase their work, and it has led to the emergence of a number of independent filmmakers during the 1990s and 2000s (Wei 2008, p. 59).

There is no denying the fact that Kawase's ability to jump from documentary to feature filmmaking was the direct result of apparatus like the Tokyo International Women's Film Festival and its support of independent women filmmakers. It was also the result of film producer Takenori Sentō's efforts to restructure the independent sector of the Japanese film industry which, during the early to mid-1990s, he perceived as lagging behind Europe and the US (Davis 2006, p. 196). ${ }^{6}$ The decline of major studios as a training ground for emerging filmmakers coupled with a demand for the diversification of content in

5 These award-wining films have cemented her position as a highly sought after and internationally renowned filmmaker and a "festival darling" whose annual presence at major festivals such as Cannes is a given in spite of the fact that more recent features—not filmed in Nara — such as Still the Water (2014), Sweet Bean (2015), and Radiance (2017) have been met with mixed reviews by an international audience (Lee 2014; Lodge 2015, 2017).

6 Takenori Sentō was the producer for Moe no suzaku and Kawase's husband from 1998-2001. 
media such as television, documentary, commercial production, and illustration, created a space for new directors to seek their training elsewhere in art and film production programs (Wada-Marciano 2012, p. 18). Since the early 2000s independent filmmakers have become major players in Japan through their ability to produce films on smaller budgets and adhering to greater restraints put on them by investors unwilling to shoulder the risk. Mitsuyo Wada-Marciano states that " ... the defining characteristic of contemporary cinema in Japan is that it belongs to the post-studio condition" (Wada-Marciano 2012, p. 14). The resulting rise of the independent film sector, working with television producers on joint ventures, reached a critical mass and under the organization of J-Movie Wars, a low-budget television series begun in 1992 to make art house films. It was in this context that Kawase's career as an independent director working outside Japan's established studio system for the film Suzaku was launched (Davis 2006; Schilling 1999).

After winning the 1997 Camera d'Or for Suzaku at Cannes, Kawase was picked up by the production company Project J-Cine-X. Created in 1999 with the specific purpose of producing theatrical pictures aimed at an overseas market, Project J-Cine- $X$ assembled and funded a group of young Japanese directors who had gained strong reputations at foreign film festivals. Modeling its production methods on those of Europe and the United States, Project J-Cine-X was acutely aware of the international exposure that European film festivals such as Cannes offered Japan's film culture, particularly in its double role of branding auteur and nation. By moving away from samurai and jidaigeki genres (period dramas referring to feudal era stories pre-1868) and recalibrating Japanese popular film with more contemporary genres, companies like Project J-Cine-X sought to lay the foundation for the new face of Japanese cinema (Davis 2006, pp. 196-97). They capitalized on the category of "independent" cinema as a placeholder for Japanese filmmakers not yet confirmed as auteurs within a transnational context and geared the content of their films toward an international film festival audience (Elsaesser 2005, p. 92).

Thomas Elsaesser's critique of the role of European film festivals as a space that is not only director-driven in its cultivation of the great auteurs of European cinema, but also sustains-as a distribution network-faltering or small national film industries offers an interesting point of reference when attempting to understand Kawase's promotion and development as a filmmaker within a Japanese context. When discussing the status of international film festivals such as Cannes, Elsaesser comments,

"The shift in selection process from country/nation to festival director also implied changes in the way the European cinema came to be perceived: while the smaller countries were able to come to international attention via the promotion of a new wave (with auteurs now representing the nation, instead of the officials who selected the national entry), the gold standard of the European festivals under the rules of Cannes became the auteur director". (lbid., pp. 90-91)

This emphasis on the auteur director became an important marketing tool for companies like Project J-Cine- $X$, ones that sought to model themselves after Western cinematic modes of production. The alignment of nation and director in order to promote Japan's national cinema, as well as boost production through low-budget art house films, was intrinsically linked to the achievement of Kawase at international film festivals such as Cannes. Indeed, as Patricia White argues, "although inclusion of women directors in competition at Cannes, Berlin, and Venice is still deficient, these events have played an important role in the emergence of women's voices from outside Europe in the present-day sector [that is] referred to as global art cinema" (White 2015, p. 29). To be sure, Kawase is part of an elite group of women, such as Jane Campion, Lucrecia Martel, Samira Makhmalbaf, Sofia, Coppola, Guo Xiaolu, and Li Yu, who have risen to the ranks of auteur director within global art cinema as a result of international film festivals and funding networks such as Cannes (Ibid., pp. 30, 225). Thus, selection by Cannes not only matters to the successful development of Kawase's career, but also to the successful development of the independent film sector that is supporting her and the overseas image of Japan's contemporary national cinema. 
During a master class at the Museum of Modern Art in New York Kawase openly discussed the difficulties of working as an independent filmmaker in Japan and the importance of winning awards at Cannes in her relation to establishing her status as a filmmaker and making a name for herself within the industry.

"With Suzaku (Moe no Suzaku, 1997) I received the new directors award at Cannes, but before that of course the film had been released in Japan and I sent preview tickets to major Japanese media outlets but very few people attended the premiere. The domestic reception of my film was quite poor and even the people who did attend the Japanese premiere left immediately after the film ended and did not speak to me. However, after receiving the new directors award at Cannes, the next film screening of Suzaku in Japan was standing room only. The theater was overflowing with people trying to get in. This time, after the film ended, everyone was rushing to interview me. It was a completely different experience. That said, I don't make films to receive awards. The award is just a tool. A means of getting as many people as possible to see my film. The award provides a reason. It creates buzz about my film without having the resources of a large studio advertising budget. It is a method that I use. It also makes it easier to solicit funding for the next film that I want to make". (Kawase 2016)

Kawase's remarks not only illuminate the difficulties that many independent filmmakers face while working outside Japan's studio system, but they also speak to the particular challenges of inclusion that women filmmakers face in an industry dominated by men. Winning awards and gaining international recognition at film festivals such as Cannes is not only crucial to Kawase's work being publicly acknowledged by Japanese critics and audiences, but also to secure funding for future projects.

Winning the Camera d'Or for Suzaku instantly legitimized Kawase's international status as a director, creating numerous opportunities to collaborate with both Japanese and European film production companies. For instance, following the success of Suzaku, Kawase's second feature Shara was coproduced by Japanese entertainment companies RealProducts and Nikkatsu, and then distributed internationally by the French company Pyramide Films. In the case of Mogari, Kawase partnered with the French film company Celluloid Dreams, which oversaw the production and distribution of her film culminating in a world premiere at Cannes and then was immediately followed by a straight to television release in Japan. Since making Shara in 2003, almost all of Kawase's narrative features have been produced in collaboration with European film companies, premiered at major international film festivals, and circulated globally with only a selection of these works returning to Japan for domestic theatrical release. ${ }^{7}$ Yoshi Yatabe, the programming director for the Tokyo International Film Festival, argues that the reason for this is "[although Kawase] has a very high reputation on the international festival circuit, her films don't really work in cinemas in Japan ... In that way, she represents a contradiction within the Japanese film industry" (Yatabe 2014). At the time of Yatabe's remarks Kawase's feature Futatsume no mado (Still the Water, 2014), a coproduction between her film company Kumie, ARTE France Cinéma, and Spanish producer Luis Miñarro, had recently been selected to compete for the Palme d'Or at Cannes. This contradiction regarding how the concept of national cinema is created from outside of Japan and to what extent the West continues to define authorship is quite telling. While Kawase may be a household name in Japan, her reputation and recognition as a director has been largely shaped by an international film festival audience. Thus, the privileging of Kawase, as an auteur through a combination of international awards, media coverage, and ongoing collaboration and investment by European production companies, has created a concept of national cinema that does not necessarily align with Japan's studio system or domestic audience.

7 Kawase has embraced this production/distribution model within her documentary work as well, having found financial support from the production company ARTE France Cinéma, which produced Kya Ka Ra Ba A (Sky, Wind, Fire, Water, Earth, 2001) and Tarachime, 2006 that won her a special mention at the Locarno Film Festival (Wada-Marciano 2012, p. 63). 
Prior to her international success, Kawase's recognition within the Japanese film industry began more modestly with her work as a documentary filmmaker. Before her arrival at Cannes in 1997, Kawase already had sixteen documentaries under her belt with the first film made in 1988 while an undergraduate at the Visual Arts College in Osaka. Kawase's documentary work is well known in Japanese film circles despite the fact that her status and practice as a documentary filmmaker has been criticized for being "too wrapped up in her own little world ... without reference to society, [and] without engaging any political or social stance" (Nornes 2002, p. 40). While the previous generation of Japanese documentarians (mostly male) saw themselves as activists "who regarded documentary filmmaking as a political act" (Schilling 1999, p. 84), Kawase is representative of a new generation of documentarians less interested in politics and social justice and more interested in biography and identity associated with personal documentary (shiteki dokyumentari).

This sentiment is directly reflected in the autobiographical nature of Kawase's early work in which she received an "Award for Excellence" at the 1993 Image Forum Festival for Ni tsutsumarete (Embracing, 1992), a film that chronicles the search for and fraught reunion with her estranged father. She also won an "Award for Excellence" at the 1995 Yamagata International Documentary Film Festival for Katatsumori (1994), which chronicles Kawase's relationship with her great aunt who raised her (Gerow 2000). Both documentaries focus on Kawase's relentless search for self as well as an attempt to deal with the dissolution of her nuclear family. ${ }^{8}$ In spite of these painful topics, Kawase's work is inflected with feelings of joy and wonder as well as an intimate connection with the natural world depicted through the rural landscape of Nara Prefecture where she grew up.

The domestic recognition Kawase received for her early award-winning documentary work, however, did not garner the kind of critical praise she was looking for. Rather Kawase's films were regarded as lacking in political gravitas or a specific ideology, and, ironically, some of her harshest critics were Japanese feminists who took issue with Kawase for appearing indifferent to the social problems that women face (Schilling 1999). Kawase has expressed her frustration at being targeted by the agendas of others, and stubbornly rejects their criticism: "I've had members of women's groups tell me I should make this type or that type of film, but I think it's strange-it becomes a kind of reverse discrimination ... For me being a woman is like having a certain shoe size-it's a natural condition, not something I think about" (Ibid., p. 85).

Kawase's refusal to accept discourses of feminism, I argue, is due in part to an awareness of what Joan Kee calls the "inclusion versus exclusion binary opposition" for contemporary Asian women artists that comes with foregrounding their gender and nationality in an effort to achieve parity with their male counterparts as well as the European and American art worlds (Kee 2011, pp. 349-50). ${ }^{9}$ That is to say, whether through the lenses of gender or gender and nation, Kawase is not interested in further marginalizing herself and her work by embracing the mantle of feminism or self-identifying as a Japanese woman filmmaker only to confirm what this categorization ultimately sets out to refuse. Yet, in spite of her resistance to identity politics and the expectations of feminist critics, within this reinvention and repackaging of Japanese national cinema, Kawase's cinematic language has become representative of a specific articulation of Japan's postwar identity in what I call a "cinema of place".

8 The concept of the nuclear family model as opposed to the intergenerational family model became a hallmark of postwar Japanese culture and is a theme that a number of Japanese filmmakers, most notably Ozu Yasujirō (1903-1963), engaged with in their postwar films.

9 Joan Kee discusses this concept in depth when she asks the question, "Is the notion of a 'contemporary Asian women's art' necessarily feminist?" In her article, Kee seeks to complicate the thinking that "contemporary Asian women's art provides a way to approach the interpretation of artworks affiliated with a specific time, space, and gender" by considering the possible negative implications embedded with these lines of critical inquiry particularly in relation to feminist agendas (Kee 2011, p. 347). 


\section{Kawase's "Cinema of Place"}

Born in 1969 in Nara prefecture, Kawase was raised by her great-aunt-whom she called "grandmother" - after being abandoned as a young child by her parents. Kawase graduated from the Visual Arts College, Osaka (formerly Osaka School of Photography) in 1989 and, while working as a lecturer at the school, she penned her first feature film Suzaku. All three of her international prize-winning features_Suzaku (1997), Shara (2003), and Mogari (2007) —are set in and around Nara, the ancient capital city of Japan. Kawase's focus on Nara underscores an important biographical component and authorial mark to her filmmaking style, emphasizing a strong level of spirituality and emotional self-awareness. The life force of close-knit, small, rural communities and their struggle to absorb the impact of Japan's postwar modernization as well as the tremendous tragedy and loss that accompanied it are ever-present in Kawase's work, reinforcing a specific image of the world in which she lives.

All of Kawase's films have been informed by and rooted to the environment in which she grew up and are predicated on certain stylistic, atmospheric, and aesthetic choices that speak to her position as mediator between her world and that of the audience's. When asked about what drew her to the medium of film as a narrative device-particularly when she grew up with little to no exposure to movies or television as a child-Kawase recalled the first time she used a camera

"... It was an assignment during [high] school to go out into the city [Nara] and take pictures of things that we liked. Up until this point I had been on a steady path of going to school, studying, and getting good grades. Everything had been proscribed and that was the life I led. Then I was told to go out into the world and find the things that I liked. Initially that was very hard but eventually I felt as if the world were coming to me. I used the camera to click the shutter and take images and a few days later I developed these images and put together a film. What surprised me the most about [this experience] was that when I screened my film in the dark, this image of a tulip appeared. But there was something else that appeared with the tulip_-it was me ... That is to say, what I discovered was an image of myself as well as an image of time passing ... In that instant I thought how wonderful images are. It [film] was like a time machine for me. Film makes possible a past or a future existence of yourself ... After that I became completely immersed in having images from my world exist within the space of film". (Kawase 2016)

Kawase's ability to both portray her world of Nara as well as the discovery of self within that world speaks to her fascination with making films based upon lived experiences-hers or those of others. Kawase describes her world as a place filled with "things that you cannot see, hidden memories that remain concealed from within ... Nara is an ancient city where much of the architecture still remains and this creates an atmosphere of strangeness where unbelievable things can happen. It gets very dark at night and the stores close quite early. So you are left with a lot of time to come face to face with yourself" (Ibid.). Because Kawase views her films as "documentary but also fiction" (Ibid.) -in which she relies upon the dual existence of an objective and subjective gaze-her approach to filmmaking no doubt informs this mediating position, and, in some cases, her directorial style may be found within the slippage between documentary and fictional storytelling. For instance, Suzaku, Shara, and Mogari Kawase were shot on location in Nara prefecture and relied primarily upon locally recruited amateur actors. Kawase limited the professional actors to one or two people, and, along with the film crew, required them to reside within the local community for two to three months prior to the start of production. All of the scenes were purposefully filmed in chronological order-a technique known as jundori-with the goal of encouraging the amateur actors to feel as if they were not acting but living in the world of the film. Kawase explains, "Instead of forcing them to act in a certain way, I tried to create an environment in which they could perform" (Schilling 1999, p. 86).

Important to an analysis of Kawase's filmmaking style and status as an auteur is our understanding of her within the context of women's cinema and female authorship. While Kawase 
would reject being categorized as "feminist" and resists the view that there is something undeniably feminine about her work, she at the same time acknowledges that being a woman director has allowed her a certain level of access that comes from being on the margins of the Japanese film industry. Kawase commented,

"It is extremely difficult for us to observe our own life, as it involves looking into the embarrassing or undesirable aspects of our lives. In a way, being a woman made it easier for me to look closely at my own environment. Women tend to be more intuitive and rely on their senses, or it might be due to gender status differences in Japan ... Not being in the mainstream or the center, she can make new discoveries. In my case, I will create things from the sources within myself. I believe that at the depth of the personal there is something universal". (Kawase 1999)

Teresa de Lauretis poses the question of aesthetics in relation to a female authorial voice when she asks, "What formal, stylistic, or thematic markers point to a female presence behind the camera?" (De Lauretis 1987, p. 131). While De Lauretis refuses to answer this question definitively by putting aesthetics in the framework of address, I believe that her posing it is generative, particularly due to the autobiographical nature of Kawase's work that attempts to deal with issues relating to memory and loss.

In Shara, for example, Kawase slowly peels away the layers of human memory in an effort to express the painful mourning process of an inexplicable tragedy. On the day of the Jizo Festival in Nara, during the oppressive heat of mid-summer, twelve-year-old Kei Aso suddenly disappears without a trace. For the three remaining members of the Aso family (father, mother, and identical twin brother Shun) time seems to stop. Five years later, seventeen-year-old Shun remains caught between the present and the past as he is unable to concretely explain what has happened to Kei. Shun as well as his mother and father silently endure the painful emotions associated with memory that have no release.

Kawase underscores the mystery of Kei's disappearance during the opening sequence of the film by aligning the handheld camera's gaze with Shun. As the brothers run through the winding streets and alleyways of their eerily silent neighborhood, the camera unsteadily trails behind the brothers. Through the repetition of the boys' bodies moving through similar spaces, Kawase creates a tension over and over between location and dislocation. The brothers' familiarity with their running route grounds them within the context of the town. Yet, the seemingly endless passage along winding streets and narrow alleyways create a jarring sense of confusion and uncertainty.

As the temporal and physical distance between the two boys slowly widens, Shun lags a few seconds behind his brother who turns right down an alleyway next to the local Buddhist temple. When Shun rounds the corner, following the echo of Kei's footsteps past the temple, he abruptly finds himself alone. Panning right and left, simulating Shun's gaze, the camera searches for Kei. Yet, there is no visual or audible trace of him. The only sound that remains is Shun's footsteps running up and down the alley, trying to find his brother. Shun retraces his steps back toward the temple and peers through the latticed window. He sees no one.

Shun's sense of confusion and panic is subtly expressed through Kawase's manipulation of profound silence. Time moves slowly for Shun and the stillness of the environment establishes a sense of foreboding. Not once during this sequence does Shun call his brother's name nor does he verbally express his emotions. Instead, his anxiety is cloaked under a veil of silence that seems to suffocate the narrow space of the alleyway. It is only after Shun leaves the alley and finds his parents that he begins to speak. Even then, in response to his mother's questioning, it is barely an audible whisper. The resulting confusion surrounding Kei's disappearance is over-laid with the voices of anonymous villagers quietly whispering the question, "Where has the child gone?" In response to this question are the words kami kakushi-a mysterious disappearance or spiriting away.

For the Aso family and the villagers, kami kakushi is the only plausible explanation for Kei's disappearance. There is no other way to describe this type of loss within such a close-knit community 
where everyone watches out for one another and the tragedy of one's family becomes the tragedy of the entire village. In her discussion of Shara Kawase commented,

“... I think ordinary people need far more strength to live than those who commit crimes ... I also wanted to focus on their problems and the theme of fading away, on the fading away of a part of us. The town of Nara offered the perfect setting with its numerous alleys. When I walk around Nara in the summer heat, I always think to myself that it would be easy to disappear down one of those alleyways. The film's central theme isn't about absence or renewal. It's the story of each and everyone of us and on the loss of a part of who we are". (Kawase 2003)

Kawase's focus on the problems of ordinary people is made specific to a certain type of rural community that copes with personal loss by absorbing the impact of major changes rather than questioning or attempting to explain them. Kami kakushi becomes a means for the community to maintain a sense of spiritual harmony and continuity in the midst of shocking tragedy.

The loss of a part of oneself is further expressed through the inherent physical and emotional connection between identical twins, with Kei's disappearance symbolizing the literal loss of a part of Shun's identity. Because there is no way to explain Kei's disappearance concretely, Shun's ability to move forward is contingent upon his capacity to both remember and forget his life with Kei and a part of himself. Kawase's proficiency at playing with our perceptions of reality is articulated through intimate observation and quiet stillness in which she lets her camera linger on the characters as they go about their daily routines-particularly Shun.

Five years after Kei's disappearance, on the day before the Jizo Festival, Shun retraces the same route he and Kei ran. As Shun silently walks the streets and alleyways, passing the same Buddhist temple, the camera moves slowly in an effort to capture the stillness of his environment. The silence is punctuated by whispers and fragments of past conversations between Shun and Kei, Shun and his mother, anonymous voices of the villagers speculating about Kei's disappearance, and Shun's own emotional breakdown when he hears the news that his brother's body has been found in the construction site of a building under demolition. When Shun reaches the alleyway next to the temple and peers through the latticed window beyond which stands a Torii gate-demarcating the transition from secular to sacred space-the voices in his head stop. The camera remains motionless. Kawase provides a long take from the perspective of Shun, allowing his gaze to linger on the gate.

Shun's ability to remember his brother is realized through the creation of a life-size portrait of Kei at age seventeen. Shun's portrait of Kei is created using an image of himself, a projection of what Kei should look like based upon the physical reflection of his identical twin. It becomes the signifier of Shun's attempt at memorializing his own identity as well as Shun's search for solace, despite his sense of deep, personal loss. Upon the completion of the painting, during a rare moment of filmic dialogue, Shun's father remarks to his remaining son "... in this world there things you can forget, there are things you have to forget, and then there are things you should not forget".

The themes of fading away and the loss of a part of oneself are also explored by Kawase in Suzaku. Set in the rural mountain village of Shino in Nara prefecture, the film centers on the Tahara family, people who eke out a living, much like their ancestors, from the ancient cedar forests. The household, consisting of father Kōzō, his wife Yasuyo, his mother Sachiko, his three-year-old daughter, Michiru, and eleven-year-old nephew Eisuke, unravels slowly as its members are unable to maintain the life that they once had. Kawase also offers us a slow and lyrical glimpse into the close-knit logging community of Yoshino, whose industry and way of life is becoming a way of the past. Thus, parallel to the disintegration of the Tahara family, is that of the village in which they live. In an effort to revive the slumping economy, Kōzō proposes the construction of a railroad tunnel through the mountains. His plan is to connect Yoshino to the outside world. When the plan fails, due to a lack of government funding, he enters a deep psychological depression. Kōzō's depression is symbolic of the economic depression of the village and the loss of its communal identity that is intricately connected to the land. 
The Tahara family's association with the rural landscape is inscribed through Kawase's long uninterrupted shots of the mountain village. Her sweeping panoramic views and tendency to quietly linger on the daily routines of the characters create a sense of melancholy and intangible sadness. In the opening establishing shots, Kawase cuts from lush green treetops swaying in the breeze to the interior of the Tahara's kitchen. With their backs to the camera Yasuyo and Sachiko silently prepare breakfast. Kawase cuts again to a view of the mountains and then pans the camera back illuminating the interior of the living room, and the open door, which frames this sublime view and underscores the connection between this household and the natural world. Throughout this series of shots, one hears the voices of children somewhere in the background. It is not until Kawase cuts again to a still shot of a mountain path that we first see Eisuke and Michiru, walking hand in hand, returning from school. Kawase's interchanging static camera shots between the landscape and the Tahara family serve to establish the close relationship of the children.

Kawase also plays with temporal space and memory in Suzaku. The shift in time is represented by an unspoken jump fifteen years forward. Rather than using editing techniques or narrative dialogue to convey this significant shift in time, as seen in Shara, Kawase quietly chooses to use Eisuke as the marker of change. As the rhythms of daily life continue, Kawase repeats the now familiar shot of Sachiko and Yasuyo preparing breakfast. The camera then cuts to the first-floor hallway with Eisuke, now a grown man, walking down the dark corridor toward the camera. His tall figure, initially unrecognizable, emerges from the darkness, integrating seamlessly into the morning routine of breakfast and chores. While Kōzō, Yasuyo, and Sachiko remain untouched by time, it is Eisuke and (in the next scene) Michiru, running out the door to school, who become the visual signifiers of change.

Silence is perhaps the most defining characteristic of this film. Through the use of gesture, body language, and blocking, Kawase conveys the power of nonverbal communication and the intimate language of a community that has existed for generations. As in Shara, there is very little dialogue. Our ability to understand the complex emotional relationships among members of the family depends upon the close observation of subtle and intimate moments of interaction. The rhythms of daily life are presented in the form of habitual repetition, sleeping, eating, cooking, and bathing, with the hub of village life centered around the Tahara's home.

The complicated relationship between Eisuke and Michiru offers the most obvious example of this intimate nonverbal language. Close since childhood, an unspoken romance develops between the two children as they grow older. Due to the absence of any kind of meaningful paternal presence, Michiru and Eisuke continue to grow closer until it becomes clear that their attraction goes far beyond familial affection. Kawase is at her best as she conveys the subtleties of this relationship through scenes that demonstrate the tension between playful affection and tender intimacy. One night, when Michiru is unable to sleep, she and Eisuke climb atop the roof of the house. Away from the rest of the family, cloaked in darkness, the two are in their own secret world playing games and seeking solace in each other. They run and laugh like children, but also stare longingly at each other like lovers. Dialogue is kept to a bare minimum. The most significant moment is at the end of the scene as they lie next to one another. Gazing up at the stars, Michiru comments, "it is beautiful".

The memory of Kōzō's failure is indicated by the departure of villagers from Shino. They leave because they are no longer able to continue supporting themselves off the land. Kōzō's continued depression becomes the emotional marker of struggle between the community and the land. Kōzō's disappearance, one afternoon while taking a walk in the forest, marks the end of both the family and the community. When Kōzō's dead body is discovered in the defunct railroad tunnel, he is clutching the family's Super- 8 camera. Before Yasuyo and Michiru leave Shino, Eisuke screens the film footage found on Kōzō's camera.

This scene is the most stunning part of the film in terms of its content and camera work. Kawase seamlessly integrates real documentary footage of the villagers who live in Shino. This footage displaces the fictional narrative of the film with the reality of the disintegration of an actual community. By framing shots of the landscape, village, and young, middle-aged, and elderly villagers one after 
another the images read like a memento mori of a vanishing people. Their shy smiles and direct gazes express a sense of self-conscious curiosity and melancholy nostalgia. Kawase's fusion of the 8-mm footage with shots of the landscape creates an aesthetic tension between the grainy unsteadiness of the handheld camera and the static panoramic 35-mm images that comprise the rest of the film.

The level of emotional intimacy that Kawase establishes between the villagers and the camera is paralleled with the departure of Yasuyo and Michiru at the end of the film. Now that Kōzō is gone, his family is unable to support themselves. Like many of the villagers before them, the Tahara family must leave their home in search of a new existence. Sachiko and Eisuke will move into the village to be closer to Eisuke's job at the inn. Yasuyo and Michiru will return to Yasuyo's childhood home to live with her parents. The dissolution of the Tahara family is symbolic of the dissolution of the village. The relationship between the people on the 8-mm footage screened in the previous scene and the final images of the Tahara family become all the more clear.

Like Suzaku and Shara, Mogari no mori is a film that deals with grief. Kawase's ability to portray the emotional immediacy of death, whether recent or decades earlier, is both haunting and uplifting. The film focuses on the relationship between an elderly man, Shigeki, and a young woman, Machiko. Shigeki is unpredictable and at times rough and feisty, battling with dementia and holding on to what memory he has left of his late wife Mako, who has been dead for thirty-three years. Shigeki takes an interest in Machiko - a caretaker in the nursing home where he lives. Like Shigeki, Machiko is also coping with the loss of a loved one, the recent death of her child. The two develop a friendship, finding in each other a source of healing and understanding. During a car trip, Shigeki wanders off on his own into the forest and Machiko follows, unable to stop him on a quest to find his wife Mako.

The word mogari signifies the period or place of mourning. Like Kawase's previous works, this one is set in the rural countryside of Nara prefecture. The association with a specific location is evident during the opening scenes that show a number of long establishing shots of the mountains, fields, and forests of Nara. Similar to Suzaku, Mogari opens with an image of lush green treetops swaying in the breeze. Here, more than ever, location and setting become important narrative devices. The natural world contains a spirit and life force that cannot be wholly understood. Kawase sets up a human connection with the landscape through extreme long shots of the rural countryside and human figures living and working within it. In many scenes, the figures are dwarfed by the lush green world that surrounds them. Kawase sends the message that humans must live in harmony with nature. Thus, it is Shigeki and Machiko's journey into the forest that marks the potential for a new beginning, and it is in the forest that both characters gain a sense of clarity. This clarity is based upon their ability to deal with the loss and grief associated with death. For both Shigeki and Machiko, this loss never goes away. It remains ever present like background noise, sometimes muffled, sometimes piercing.

Throughout the film, Kawase uses very few cuts or explanations, particularly in the forest scenes where the narrative drive is dependent upon the imagery and the range of emotions shared between Shigeki and Machiko. It is in the forest that the impact of Machiko's loss becomes ultimately apparent. While it is unclear how Machiko's child died, the overriding message is that the death was, in some way, her fault. Blindly following Shigeki on his quest for Mako, Machiko's role as caregiver is tested again and again. Lost and wandering in the rain, they arrive at a stream, which Shigeki attempts to cross. Calling after Shigeki, Machiko begs him not to continue, arguing that it is too dangerous. Refusing to heed her warning, Shigeki pushes onward. Suddenly, the water upstream comes rushing toward him. The current is strengthened due to the pouring rain. During this climactic moment, Kawase points the camera at the rushing water and holds a close-up of the stream. Over the sound of rushing water, all that is audible is Machiko's cries as she screams "No!" and "I'm sorry, I'm sorry, I'm sorry".

When the camera cuts back to Shigeki, he is holding onto a mossy rock, soaking wet but alive. As he cautiously returns to the edge of the stream and to safety, Machiko's cries become louder. She no longer looks at him but crouches on the ground, turning inward as her body convulses in tears. Machiko's repeated apologies of "I'm sorry," despite the fact that Shigeki is safe, suggest that it is 
not Shigeki to whom she is speaking but rather her dead child, who had perhaps drowned. Shigeki approaches Machiko and says, "The water of the river, which flows constantly, never returns to its source". His ability to recognize the pain of Machiko's loss creates a window of access for the audience. Shigeki gently holds Machiko while she cries, aware of the painful memories that his attempted stream crossing has provoked.

Following this scene is another memorable moment in the film that speaks to the powerful bond between Shigeki and Machiko. Through the use of gesture, body language, and blocking, Kawase conveys the intensity of nonverbal communication. Wet and cold, Shigeki and Machiko prepare themselves for a night in the dark forest. In an effort to stay warm and dry, Shigeki builds a fire, but the heat from the blaze is not enough to fend off the hypothermia he experiences as a result of the rain. In an effort to keep Shigeki warm, Machiko begins to rub his arms and legs. Soon realizing that this is not enough, she takes off Shigeki's shirt as well as her own and wraps herself around him, using her bare flesh to heat his water-chilled body. Covered in darkness, the two figures are only visible by firelight. The silence and static position of the camera angle de-emphasizes this as a sensual or sexual act. Instead, it symbolizes the intensity of their relationship in terms of mutual understanding and humanity. Regarding the relationship between these characters Kawase comments,

"I think the bond between Shigeki and Machiko is empathy. They share something one cannot control: the time they spent with the departed. But it's certainly not only a sharing of sadness. In human existence, those who've experienced loss often become kinder to others. This only happens, however, if there's someone who understands them ... After the two enter the forest, the forest becomes the force that supports them. It watches over them, sometimes gently, sometimes more strictly". (Kawase 2007)

The conclusion of the film is somewhat ambiguous. Shigeki and Machiko's journey ends when Shigeki discovers the wooden tomb marker indicating the location of Mako's body. Overjoyed, he pulls from his backpack stacks of journals—-thirty-three in total—one recording for every year since Mako's death. He also pulls out a small music box that belonged to his late wife. Spreading the objects around the wooden tomb marker Shigeki proceeds to dig into the soft earth. With Machiko's help, he is able to create a small shallow grave in which to lie down. During their frenzied digging, the approaching sound of a helicopter can be heard. The camera follows Shigeki's and then Machiko's gaze upward toward the sky as she searches for the source of the noise, but all that is visible is the canopy of tree branches.

Curling into the fetal position and pressing his face against the soil, Shigeki announces that he is going to sleep in the earth. His apparent readiness for death symbolizes his ability to come to terms with the loss of his wife. Shigeki and Machiko tenderly thank each other for the help and support they have shared. The camera lingers on a close-up of Machiko's dirty hand resting on Shigeki's. As Shigeki closes his eyes, Machiko turns the handle on the small music box, and plays a sad and lonely lullaby. Through her tears, she tells Shigeki that everything is all right now. Machiko continues to play the music box, turning her gaze back toward the sky and raising her arms in the air. The gaze of the camera lingers on Machiko's face, then it pans back moving to a panorama of the forest. The faint sound of the music box and her tears are all that remain.

\section{Art Cinema as National Cinema}

Kawase has been described as "ultra-arty" and more of a critics' darling than an audience favorite (Schilling 2007b). This characterization speaks directly to her filmmaking style and has served her well within the international film community. She has earned three prestigious awards at Cannes, with Mogari beating out a celebrity field of male auteurs that included the Coen Brothers, David Fincher, Quention Tarantino, and Wong Kar-wai (Schilling 2007a). While it is clear that Kawase's aesthetic choices and narrative content avoid most commercial and formulaic considerations, the question that 
remains is whether or not her work should be defined within the context of "art cinema"; and, if so, how does this definition of her work re-conceptualize Japan's national cinema within a regional context?

The three main components of art cinema are realism, authorship, and ambiguity. Art cinema, "motivates its narrative by the principles of realism and authorial expressivity ... and privileges stylistic devices for representing a realistic continuum of space and time" (Bordwell 1999, pp. 718-19). The stylistic devices utilized by Kawase in all three of her feature films clearly fall under the categories outlined by Bordwell. In terms of realism and authorship, the settings and themes of her works are defined not only by their connection to contemporary Japanese culture, but Kawase's personal biography and background as a documentary filmmaker. Family dramas are set in and around the ancient capital of Nara. They deal with issues of death, loss, memory, and the relationship between humanity and the natural order. However, in all of Kawase's works there is a spiritual element inscribed into the landscape which tends to blur the boundary between the living and the dead. We see this most clearly in Shara with Kei's disappearance and the idea of kami kakushi. It is also present in Mogari, with the forest containing an intangible and somewhat spiritual force that supports and watches over Shigeki and Machiko.

While these films are not directly autobiographical, Kawase's authorial inscription is structurally foregrounded in a number of ways. The recurring elements of memory, loss, familial, and close-knit communal relationships, the specificity of location to Nara prefecture, and stylistic devices used to drive the narrative, all contain a biographical component. In many cases, these components of her feature films have previously been explored in earlier documentaries such as Ni tsutsumarete and Katatsumori where Kawase's minimal use of editing, emphasis on silence, manipulation of temporal durations, loose narrative structures resembling real-life, and concern with reaction rather than action, all reference the author's point of view in her films and unify the text. Rie Karatsu has argued that Kawase's particular style- "her mixing of documentary and fiction, the autobiographical documentation and formal articulation" (Karatsu 2009, p. 169)—exposes the authorial role(s) that she plays both in front of and behind the camera. Karatsu states,

"In Mourning Forest, Kawase exposes these dual roles effectively without making herself appear like an actress in the film. Kawase makes her role as a director visible by deploying Wakako [a senior colleague of Machiko's at the nursing home] as herself behind the camera and Shigeki as herself in front of the camera". (Ibid., p. 175)

Karatsu maintains that Kawase uses the characters of Wakako and Shigeki as a form of authorial inscription-one that Kaja Silverman has termed a "second identification" (Silverman 1988, pp. 212-18) - in which the fictional characters stand in for the film's director to express her views on filmmaking. For instance, the repetition throughout the film of Wakako's line "there are no formal rules here" underscores Kawase's approach to filmmaking that breaks from the conventions of documentary film (Karatsu 2009). Similarly, Kawase uses Shigeki as a foil to mediate on her own emotional output commenting that, "I think my personal view of life is reflected in the character of Shigeki and his living through the memory of his dead wife. But these factors aren't autobiographical. The story of Mogari is rather a reflection of the emotions within me" (Kawase 2008).

Interestingly, however, in Shara Kawase's authorial inscription through second identification extends beyond her position behind the camera by actually starring in the film as Reiko-Shun's mother-thus reversing the role of loss that she herself had experienced as child when abandoned by her parents. In this case, Kawase plays a parent who has lost a child, and, during the second half of the film, her character Reiko-who is pregnant-gives birth to a baby boy. During the filming of Shara, Kawase herself was pregnant with her own child and played the role of Reiko with a profound sense of authenticity. One of the final scenes of the film depicts the birth of Reiko's newborn son. Performing the role of a parent who has lost a child is not only an extremely painful form of self-inscription, but also a marker of Kawase's ego and how tenuous the line between fiction and documentary can be. In this case, the duality of her roles in front of and behind the camera collapse into one and authorial inscription becomes part of both physical and textual realism of the film. 
This is not the first time that Kawase utilizes this mode of authorial inscription in her work. We see it almost ten years earlier in a scene from her documentary Katatsumori in which Kawase, while filming, impulsively reaches out from behind the camera, allowing her hand to appear in the frame as she touches her grandmother's face. Kawase describes this impulse as the subjectivity of a daughter reaching for her grandmother, and the act of capturing this impulse on film as the objectivity of the artist/filmmaker documenting the act. "In that moment there existed two of me... In that one shot I came to realize that within myself I have this dual existence of the objective and the subjective" (Kawase 2016). This dual existence between the objective and subjective points of view in her work represented through acts of authorial self-inscription has become a defining feature of Kawase's work as well as an important means of narrative creation. It is this mode of filmmaking that allows Kawase to challenge the structures and boundaries of Postwar Japanese cinema by conferring a new framework for the auteur within an art cinema context.

But what, if anything, makes Kawase's authorial presence and/or gaze in all three of these films' distinctly female? Whose reality are we seeing? These questions directly engage with Bordwell's third component of art cinema: ambiguity. ${ }^{10}$ While there are significant aspects of ambiguity in the narrative of all three of Kawase's films, whether it be the mystery surrounding Kei's disappearance and death in Shara, the uncertain future of Shino village and the remaining members of the Tahara family in Suzaku, or the rescue of Shigeki and Machiko at the end of Mogari, there is also a level of ambiguity in terms of how to read Kawase's gaze or voice as distinctly female. Themes of loss, memory, and the dissolution of the family are not specific to Kawase (and she would be the first to make this point). Many of these themes are found in the works of her male contemporaries, such as Kore'eda Hirokazu who deals with a similar set of issues in the films Wandäfuru raifu (After Life, 1999) and Dare mo shiranai (Nobody Knows, 2004). In his analysis of Kawase's film Shara, Timothy Iles argues that Kawase's gaze is "inclusive" - neither male nor female in its visual presentation. Iles comments,

"Kawase has created a visual style capable of presenting both men and women with equal acceptance ... No one character or gender becomes the focal point of 'visual pleasure,' to borrow the phrase from Laura Mulvey, of this film, just as the voice of no one gender becomes that through which the film 'speaks' its message". (Iles 2008, p. 61)

Thus, instead of looking for a female gaze or voice based upon thematic or narrative content, I believe that we must look for it in terms of Kawase's position as a mediator between her world and the world of her audience. This mediation strikes a balance between the objective and subjective in her work. Her unrelenting search for self is expressed through a visual articulation of emotion that drives the form of narrative creation. Kawase's own "voice" is expressed through the sensitive and close observation of the community to which she belongs. It is her regional specificity and attention to the subtle yet complicated stories and relationships among ordinary people, which are typically ignored or forgotten, that makes her work so distinctive. It is the combination of self-reflection, story-telling, and personal exploration that drives Kawase's aesthetic and foregrounds her viewpoint-this simultaneous objective and subjective "gaze" —as feminine.

Kawase's self-promotion as an auteur within the context of art cinema is directly aligned with the promotion of Japan's national cinema. In his article, "Reconceptualizing National Cinema/s" Stephen Crofts argues, "underpinning First World approaches to national cinema is the master antinomy of self vs. other ... National cinematic self-definition, like national self-definition, likes to pride itself on its distinctiveness, on its standing apart from other(s)" (Crofts 1994, p. 47). More recently, in the case of Japan,

10 According to David Bordwell, "When confronted with a problem in causation, temporality, or spatiality we first seek realistic motivation. (Is a characters' mental state causing the uncertainty? Is life just leaving loose ends?) If we're thwarted we next seek authorial motivation. (What is being "said" here? What significance justifies the violation of the norm?) ... When obvious uncertainties persist, read for maximum ambiguity. With the open arbitrary ending, the art film reasserts that ambiguity is the dominant principle of intelligibility, that we are to watch less for the tale than the telling, that life lacks the neatness of art". See (Bordwell 1999, p. 721). 
definitions of "self" have moved away from traditional and stereotypical versions articulated in filmic genres such as samurai and yakuza, toward ones that focus on a more specific and local identity within a contemporary global context. Kawase's cinema of place seeks to do just that by foregrounding the regionality of Nara's landscape, people, and language, while also attending to the "particular tendencies of European art cinema, such as Jeane-Pierre and Luc Dardenne's films," which Wada-Marciano argues "places her regional work within a global cinematic context" (Wada-Marciano 2012, p. 56).

Kawase's award-winning films attest to these new definitions of self by successfully capitalizing on the demand for art cinema whose content embraces the varied aspects of Japan's regional identities and communities. They also demonstrate her ability to cultivate a space for filmmakers and audiences alike who are interested in engaging with a cinematic vision of postwar Japanese culture and society defined by a specificity of place. In 2010, just three years after winning the Grand Prix for Mogari Kawase founded the Nara International Film Festival (NIFF), which is a biennial festival that seeks to provide opportunities for young independent filmmakers working outside of Japan's studio system. As part of the festival, NIFF also developed a program called NARAtive, which invites emerging directors from around the world to come to Nara, Japan and make a film set in the region. Supported by NIFF staff and local film crews, these international filmmakers are tasked with creating a narrative film that represents the peoples, environments, and histories of the Nara region. These films make their debut at NIFF and then travel to other international film festivals with the goal of promoting NIFF as well as the work of these young filmmakers. ${ }^{11}$ NIFF not only allows Kawase to act as a mediator between her world of Nara and that of her audience, but it has created a platform for her to promote and market a new brand of national cinema that takes pride in its hometown/local identity through filmmaking and film viewing.

This is perhaps most evident in her 2012 TEDxTokyo talk: "The Value of Movies". Part autobiography, part manifesto, and, most significantly, publicity content for NIFF, Kawase argues for the importance of cinema as well as the apparatus of the international film festival to transcend the structures and boundaries of geographic and temporal space. "Films," Kawase declares "can overcome boundaries ... Films can overcome oceans and they let us share our emotions with one another. I believe there is nothing stronger than the emotions we share ... The international film festival is not just for watching movies but it can become a bridge that connects people through their shared love of cinema" (Kawase 2012). Yet, this bridge that Kawase speaks of is one she has designed specifically to connect her cinema of place with the rest of the world.

\section{Conclusions}

The expression of Japan's national character as both unique and separate from other nations within, as well as outside of, Asia has always been at the forefront of modern Japanese visual culture. Kawase's films—Suzaku (1997), Shara (2003), and Mogari (2007)—provide the level of difference necessary for the distinction of an authentic Japanese "self" separate from the "other" in terms of the nation's geographic as well as cultural specificity—ancient capital of Nara, Japan, Shinto, and Buddhism, daily habits, and routines of a close-knit community-while, at the same time, themes of loss, memory, death, and the dissolution of the family remain accessible on a universal level. Kawase's dualistic mode of storytelling authorizes both a national and international meaning of the modern Japanese identity. Because of her independent status from Japan's studio system, in the creation of these films-frequently shooting on-site (far away from filmmaking centers like Tokyo and Kyoto) and with amateur actors-Kawase is able to avoid the commercial and formulaic modes of filmmaking that

11 Since NARAtive was founded in 2010 a total of five films directed by international filmmakers have been produced in Nara Japan, premiered at the Nara International Film Festival, and distributed worldwide: (1) Last Chestnuts (2010) dir. Zhao Ye, Kashiahra City, Nara Japan; (2) Inori (2012) dir. Pedro González-Rubio, Totsukawa Village, Nara Japan; (3) A Midsummer's Fantasia (2014) dir. Jang Kun-jae, Gojo City, Nara Japan; (4) Wolves of the East (2016) dir. Carlos M. Quintela, Higashiyoshino Village, Nara Japan; and (5) Nikaidos' Fall (2018) dir. Ida Panahandeh, Tenri Village, Nara Japan. 
serve to undermine the aesthetic and cultural specificity associated with her "cinema of place". ${ }^{12}$ The alignment of director and nation, in order to promote Japan's national cinema uniquely separate from the West and to boost production through art cinema, is intrinsically linked to Kawase' achievements at international film festivals such as Cannes, which have enthusiastically embraced her discourse of auteurism defined by regional identity. Thus, within the international film festival framework, Kawase has successfully branded herself and her films with the double status of auteur and nation. The unification and promotion of these two categories by Kawase and, subsequently, the Japanese film industry, places her squarely within the realm of auteur director.

So where does this leave us in regard to Kawase's claim? Does she have the potential to become the next internationally known name among this generation of Japanese filmmakers? While Kawase has yet to win the coveted Palme d'Or, she has certainly established herself as a filmmaker who, depending upon the context, represents not only Japanese national cinema, but women's cinema as well as independent and art cinema. It is also clear that Kawase understands the burden of representation that comes with being one of the most successful contemporary Japanese female filmmakers. While she rejects the expectation that her work must specifically exemplify women or women's issues, she openly acknowledges that her marginal status of being a woman director allows for greater levels of access, mobility, and risk-taking in her work. Kawase's "female exceptionality" has provided her with the freedom to make new aesthetic discoveries and cultivate a specific filmmaking style-a dual existence of the objective and subjective gaze-that draws upon a combination of personal experience and geographic specificity to articulate a "cinema of place". Whether or not all of her films are critically and commercially successful, Kawase and her work have certainly captured and will continue to capture international attention.

Funding: This research received no external funding.

Acknowledgments: I sincerely thank Patty White for introducing me to the films of Naomi Kawase many years ago in her graduate seminar "Women's Cinema/World Cinema" as well as for her continued support and encouragement of my research on this topic. I would also like to thank my colleagues Marilyn Boltz, Richard Freedman, Andrew Friedman, Christina Knight, Aniko Szucs, and Joel Yurdin, who participated in the 2017-2018 Faculty Humanities Seminar at Haverford College and provided me the opportunity to share aspects of this work in progress. Finally, I would like to thank the anonymous reviewers of Arts for their invaluable comments and feedback on earlier versions of this article.

Conflicts of Interest: The author declares no conflicts of interest.

\section{References}

\section{Filmography}

Sharasoju, Fukunaga Kohei, Hyodo Yuka, Namase Katsuhisa, and Higuchi Kanako, dir. Naomi Kawase. 2003. Nikkatsu Kabushiki Kaisha.

Moe no suzaku, Sentō Takenori and Kobayashi Koji, dir. Naomi Kawase. 2005. Les Films du Paradoxe.

Mogari no mori (The Mourning Forest), dir. Naomi Kawase. 2007. Kumie.

Katatsumori; Ten, miteke = See heaven; Hi wa katabuki, dir. Naomi Kawase. 2008. Kumie.

Mogari no Mori o Ikite (Living through Mourning Forest), dir. Naomi Kawase. 2008. Kumie.

Ni tsutsumarete = Embracing; Kyakarabaa $=$ KyaKaRaBaA, dir. Naomi Kawase and Uno Kawase. 2008. Kumie.

12 This is especially true within the context of Kawase's personal documentaries. As Mitsuyo Wada-Marciano observes, " ... without any sponsors and thus without any artistic restrictions, Kawase is free to disengage herself from the reliable meaning of images that constrains the 'rules' of documentaries. Kawase's personal films are promoted through international film festivals as the work of an auteur and are sold directly from her official Internet site". See (Wada-Marciano 2012, p. 66). 


\section{Bibliography}

Bordwell, David. 1999. Art Cinema as a Mode of Film Practice. In Film Theory and Criticism: Introductory Reading. Edited by Leo Braudy and Marshall Cohen. New York and Oxford: Oxford University Press, pp. 716-24.

Corrigan, Timothy. 1991. A Cinema without Walls: Movies and Culture after Vietnam. New Brunswick: Rutgers University Press.

Crofts, Stephen. 1994. Reconceptualizing National Cinema/s. In Film and Nationalism. Edited by Alan Williams. New Brunswick and London: Rutgers University Press, pp. 25-51.

Davis, Darrell William. 2006. Japan: Cause for (Cautious) Optimism. In Contemporary Asian Cinema: Popular Culture in a Global Frame. Edited by Anne Tereska Ciecko. Oxford and New York: Berg, pp. 193-206.

De Lauretis, Teresa. 1987. Technologies of Gender: Essays on Theory, Film, and Fiction. Bloomington: Indiana University Press.

Elsaesser, Thomas. 2005. European Cinema: Face to Face with Hollywood. Amsterdam: Amsterdam University.

Gerow, Aaron. 2000. Documentarists of Japan, No. 14: Kawase Naomi. Documentary Box 16: 2-16.

González-López, Irene, and Michael Smith, eds. 2018. Tanaka Kinuyo: Nation, Stardom and Female Subjectivity. Edinburgh: Edinburgh University Press.

Iles, Timothy. 2008. The Crisis of Identity in Contemporary Japanese Film: Personal, Cultural, National. Leiden: Brill.

Karatsu, Rie. 2009. Questions for a Women's Cinema: Fact, Fiction and Memory in the Films of Naomi Kawase. Visual Anthropology 22: 167-81. [CrossRef]

Kawase, Naomi. 1999. Naze ima josei nanoka. Gekken Bijutsu 25: 45-48, quoted in Karatsu, Rie. 2009. Questions for a Women's Cinema: Fact, Fiction and Memory in the Films of Naomi Kawase. Visual Anthropology 22: 170.

Kawase, Naomi. 2003. Naomi Kawase's Humanity. Le Quotidien, May 24. Available online: http:/ /www.festivalcannes.com/fr/theDailyArticle/42776.html (accessed on 3 July 2015).

Kawase, Naomi. 2007. Competition: 'Mogari no Mori' (The Mourning Forest) by Naomi Kawase. Le Quotidien, May 26. Available online: https:/ / www.festival-cannes.com/en/69-editions/retrospective/2007/actualites / articles/in-competition-mogari-no-mori-the-mourning-forest-by-naomi-kawase (accessed on 3 July 2015).

Kawase, Naomi. 2008. Mogari no Mori o Ikite (Living through Mourning Forest). The DVD Special Feature, quoted in Karatsu, Rie. 2009. Questions for a Women's Cinema: Fact, Fiction and Memory in the Films of Naomi Kawase. Visual Anthropology 22: 176.

Kawase, Naomi. 2012. The Value of Movies. TEDxTokyo Video, 13:00. June 30. Available online: http:/ /archive. tedxtokyo.com/talk/naomi-kawase/ (accessed on 2 December 2018).

Kawase, Naomi. 2016. Naomi Kawase Master Class. Paper presented at the Museum of Modern Art, New York, NY, USA, June 26.

Kee, Joan. 2011. What is Feminist About Contemporary Asian Women's Art? In Contemporary Art in Asia: A Critical Reader. Edited by Melissa Chiu and Benjamin Genocchio. Cambridge: MIT Press, pp. 347-69.

Lee, Maggie. 2014. Cannes Film Review: 'Still the Water'. Variety U.S. Online, May 20. Available online: http://variety.com/2014/film/asia/cannes-film-review-still-the-water-1201186839/ (accessed on 16 July 2015).

Lodge, Guy. 2015. Cannes Film Review: 'An'. Variety U.S. Online, May 14. Available online: http:/ /variety.com/ 2015/film/festivals/an-review-sweet-red-bean-paste-1201495660/ (accessed on 20 July 2015).

Lodge, Guy. 2017. Cannes Film Review: 'Radiance'. Variety U.S. Online, May 23. Available online: https:/ variety. com/2017/film/reviews/radiance-review-1202440989/ (accessed on 28 November 2018).

Nakane, Wakae. 2018. Constructing an Intimate Sphere through her Own Female Body: Naomi Kawase's Documentary Films. In Female Authorship and the Documentary Image: Theory Practice and Aesthetics. Edited by Boel Ulfsdottoer and Anna Backman Rogers. Edinburgh: Edinburgh University Press, pp. 171-85.

Nornes, Abé Markus. 2002. The Postwar Documentary Trace: Groping in the Dark. Positions: East Asia Culture Critique 10: 39-78. [CrossRef]

Schilling, Mark. 1999. Contemporary Japanese Film. Boston and London: Weatherhill Press.

Schilling, Mark. 2007a. Mogari no Mori: Human Warmth through Understanding. Japan Times, June 22.

Schilling, Mark. 2007b. Naomi Kawase: Critical Favorite Directed 'Mourning Forest'. Variety, July 30. Available online: https://variety.com/2007/biz/markets-festivals/naomi-kawase-1117969267/ (accessed on 24 April 2008).

Silverman, Kaja. 1988. The Acoustic Mirror. Bloomington and Indianapolis: Indiana University Press. 
Tezuka, Yoshiharu. 2012. Japanese Cinema Goes Global: Filmworkers' Journeys. Hong Kong: Hong Kong University Press. Ulfsdottoer, Boel, and Anna Backman Rogers, eds. 2018. Female Authorship and the Documentary Image: Theory Practice and Aesthetics. Edinburgh: Edinburgh University Press.

Wada-Marciano, Mitsuyo. 2012. Japanese Cinema in the Digital Age. Honolulu: University of Hawaii Press.

Wei, Louisa S. 2008. Chinese and Japanese Female Film Directors: Could they Hold up Half the Sky? In The Global Cartographies of Cine-Feminism. Edited by Jai-ran Byun. Seoul: International Women's Film Festival, pp. 59-100.

Wei, Louisa S. 2011. Women's Trajectories in Chinese and Japanese Cinemas: A Chronological Overview. In Dekalog 4: On East Asian Filmmakers. Edited by Katie E. Taylor. London: Wallflower Press, pp. 13-44.

White, Patricia. 2015. Women's Cinema, World Cinema. Durham and London: Duke University Press.

Yatabe, Yoshi. 2014. Japan's Female Director's Making their in Patriarchal Industry. The Hollywood Reporter, April 1. Available online: https:/ / www.hollywoodreporter.com/news/japans-female-directors-makingmark-692070 (accessed on 12 March 2019).

Yoshida, Mayumi. 2001. Josei kantoku eiga no zenbō = Films of the World Women Directors. Tokyo: Pado Uimenzu Ofisu. Yoshimoto, Mitsuhiro. 2000. Kurosawa: Film Studies and Japanese Cinema. Durham and London: Duke University Press.

(C) 2019 by the author. Licensee MDPI, Basel, Switzerland. This article is an open access article distributed under the terms and conditions of the Creative Commons Attribution (CC BY) license (http:/ / creativecommons.org/licenses/by/4.0/). 
MDPI

St. Alban-Anlage 66

4052 Basel

Switzerland

Tel. +41 616837734

Fax +41 613028918

www.mdpi.com

Arts Editorial Office

E-mail: arts@mdpi.com

www.mdpi.com/journal/arts

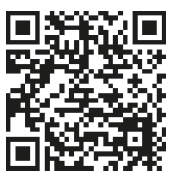



MDPI

St. Alban-Anlage 66 4052 Basel

Switzerland

Tel: +41 616837734

Fax: +41 613028918 